\title{
EXERCÍCIOS DE LEITORIA
}

Tese apresentada ao Programa de Pós-Graduação em Artes Visuais da Universidade de São Paulo, como exigência parcial para a obtenção do título de Doutor em Artes.

Área de concentração: Poéticas Visuais.

Orientadora: Profa. Dra. Ana Maria da Silva Araújo Tavares. 
Jorge Mascarenhas Menna Barreto

\section{EXERCÍCIOS DE LEITORIA}

\section{Presidente da Banca:}

Profa. Dra. Ana Maria da Silva Araújo Tavares

Instituição: USP

Banca Examinadora:

$\operatorname{Prof}(a) \operatorname{Dr}(a)$

Assinatura

Instituição: .

$\operatorname{Prof}(a) \operatorname{Dr}(a)$

Assinatura

Instituição:

$\operatorname{Prof}(a) \operatorname{Dr}(a)$

Assinatura

Instituição:

$\operatorname{Prof}(\mathrm{a}) \operatorname{Dr}(\mathrm{a})$

Assinatura

Instituição:

São Paulo, 2012. 
Aos que leem além

e lançam os dados aléem 
Agradeço aos amigos; aos professores, todos eles, com imenso respeito e carinho; à Zezé, pela acolhida; ao Caio Yurgel, pelos ensinamentos; à Cynthia Vasconcellos, pela parceria; ao Helmut Batista, pelos rios compartilhados; a Falke Pisano e Max Hinderer, pelos diálogos; ao Lucas Oliveira, pela assistência; a Monica Tavares e Ricardo Basbaum, pelas contribuições; à Ana Maria Tavares, pelo olhar preciso. 
[...] todas as leituras incidem em erro, porque supõem a sua própria legibilidade.

Paul de Man 
Este trabalho se propõe a analisar um grupo de oito obras de minha trajetória artística que se constroem enquanto respostas autorais a leituras de obras de outros artistas e autores. As concepções de leitura e autoria tanto se chocam, produzindo o termo leitoria, quanto se afastam, explorando os diversos matizes entre as duas tarefas. A reunião das obras no solo conceitual proposto é posterior às suas realizações em situações e tempos distintos. Desvinculadas de seus contextos originais, fundam uma nova vizinhança que salienta os seus aspectos comuns, já que se agregam aqui por afinidade. Não se pretende, com isso, reduzir as obras à narrativa desenhada, mas multiplicar as possibilidades de leitura que compreendem, evidenciando assim a singularidade com que cada uma se relaciona com o discurso produzido. Para tratar os múltiplos deslocamentos traçados entre obras, autores, textos e contextos, a tese lança mão de diferentes concepções de tradução, entendida como uma ação complexa e que reivindica visibilidade. Finalmente, o texto busca demonstrar a relação problemática com o ambiente acadêmico onde se inscreve ao abordar a ideia de pesquisa artística e as contradições que o tema abriga no cenário da arte contemporânea.

Palavras-chave: tradução, desleitura, pesquisa artística, leitura. 
This thesis analyses a group of eight works of my artistic career which were thought of as authorial responses to readings of works by other artists and authors. The conceptions of reading and authorship colapse, creating the expression leitoria (reawriting); as well as expand the space between them, exploring several hues of that distance. Gathering these works on this conceptual ground is posterior to the specific times and situations for which they were designed. Dettached from their original contexts, they structure a new propinquity which emphasises what they share in common, since they are here joined by affinity. The intention is not to reduce the works to the given narrative, but multiply the possibilities of readings they comprehend, bringing light to the singularities with which they relate to the discourse created. To approach the multiple relations drawn among works, authors, texts and contexts, the thesis uses different conceptions of translation, understood as a complex task which claims visibility. Finally, the text brings about the problematic relation between artistic research and the academic field where this work is inscribed, approaching the contradictions this issue hosts in the contemporary art scene.

Key-words: translation, misreading, artistic research, reading. 


\section{SUMÁRIO}

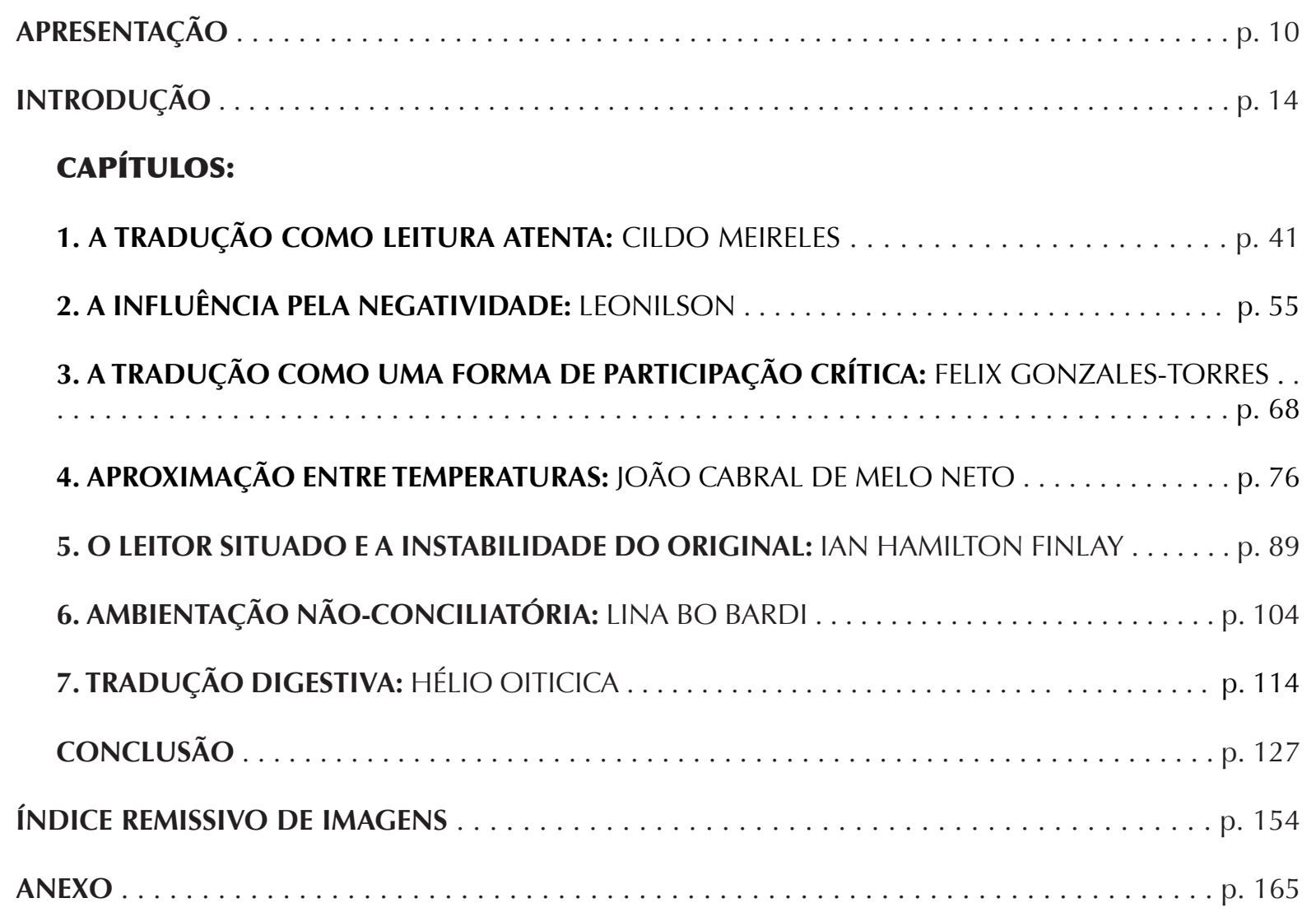




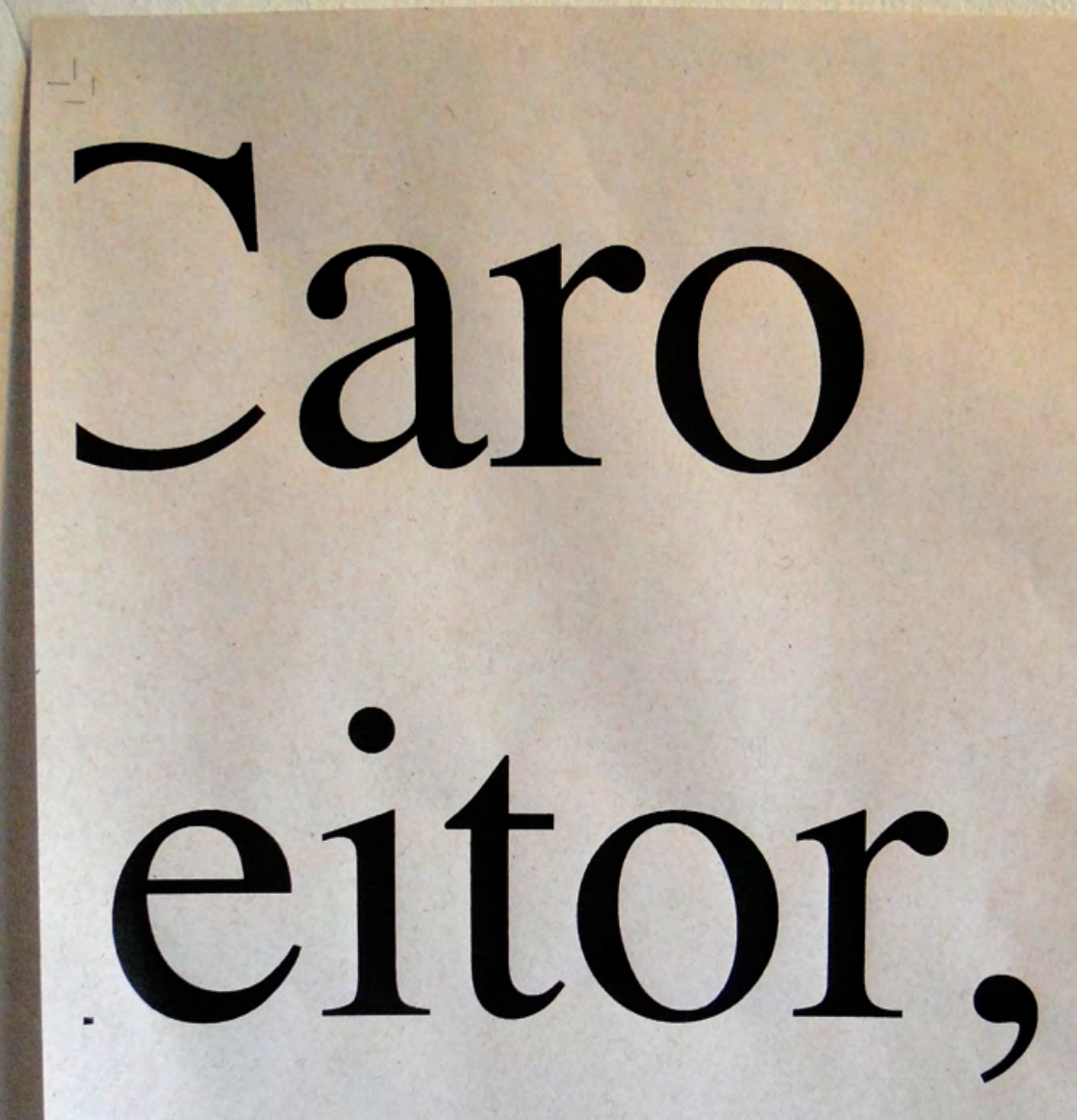


O doutorado costuma ser um dos momentos mais importantes na formação acadêmica. No campo das artes, na linha de Poéticas Visuais, desenvolver uma pesquisa de doutorado tem se revelado como um interesse crescente por parte dos artistas cujas práticas enfatizam a pesquisa e o aspecto discursivo da obra. Além disso, tornar-se doutor é uma qualificação importante para aqueles que gostariam de seguir a carreira acadêmica. A discussão sobre o artista na universidade é longa e escapa aos objetivos desta investigação. No entanto, a reflexão sobre a formação do artista perpassa-lhe, seja considerando a ideia de pesquisa no próprio ambiente onde a tese se inscreve, seja no capital pedagógico do tema que aborda.

A pesquisa proposta analisa e revisa conceitos que venho desenvolvendo em minha prática artística nos últimos doze anos, coerente com o que tem sido feito na linha de pesquisa de Poéticas Visuais do Departamento de Artes (ECA-USP). Isso explica a recorrência da conjugação dos verbos na $1^{a}$ pessoa do singular. Já na introdução, busco situar a problemática no início da minha formação acadêmica na década de 1990 no Rio Grande do Sul. Durante esses vinte anos, entre a graduação em Artes Plásticas (1991-97), mestrado em Poéticas Visuais (2004-07) e o doutorado (ingresso em 2008), a universidade pública tem sido espaço privilegiado e central na minha produção artística, fortalecendo a sua vocação reflexiva. O meio acadêmico não somente tem ocupado um lugar de destaque, como influenciado grande parte da minha produção de maneira indelével. Prova disso tem sido a atuação como educador, crítico e tradutor, interceptando a minha prática artística e gerando híbridos como o Projeto Matéria (2004), quando, ao ser selecionado por um edital para realizar uma exposição individual no Programa de Exposições do Centro Cultural São Paulo, propus a instalação de uma sala de aula no espaço expositivo, onde realizei uma oficina durante o período da mostra ${ }^{1}$.

1 O Projeto Matéria consistiu em uma oficina de oito encontros para um grupo fixo de quinze pessoas. A cada encontro, havia um convidado especial para tratar de um tema específico. Online: Disponível em: 
O olhar que apresento na tese contém uma dose considerável de retrospecção. Mesmo que não contemple toda a minha produção, o recorte que realizo pretende elucidar algumas de suas características mais marcantes, as quais integram a hipótese central. De diferentes maneiras, na relação que estabelece com o olhar reflexivo e investigativo, minha produção tem sido irrigada por diferentes desdobramentos das noções de leitura e tradução, tratadas ao longo do texto. Conceitualmente, a pesquisa se utiliza das concepções de desleitura (ou misreading), tradução (como transcriação), origem (enquanto descolamento do contínuo da história) e pesquisa artística (como leitura forte e alternativa), apresentadas na introdução. A partir de diferentes autores, busco ressaltar aquilo que esses conceitos compartilham de uma qualidade desviante, especificidade que atribuo ao olhar poético.

A partir de uma leitura atenta da minha produção artística, selecionei um grupo de obras que estabelecem um diálogo intensivo com a produção de outros autores. A motivação para reuni-las no contexto da tese é semelhante à pulsão curatorial de seleção, agrupamento e organização de obras e artistas sob uma determinada narrativa. Cada capítulo

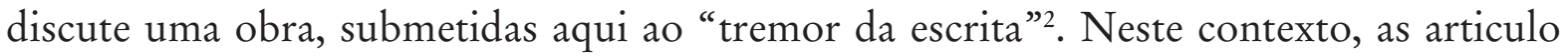
enquanto traduções dos autores aos quais respondem, produzindo assim uma constelação de hipóteses que alimenta o eixo principal deste trabalho. Obras enquanto hipóteses, ou hipóteses que geram obras: hobras. Deve-se atentar para a diferença entre obras e hobras. As obras de minha autoria que foram aqui selecionadas, realizadas em contextos e tempos específicos, tornam-se hobras ao migrarem para a tese. O "h" adicionado opera como sinalizador de uma transposição. Nenhuma das obras analisadas foi pensada originalmente para este contexto. Seu deslocamento espacial, temporal e entre linguagens requer, portanto, uma elaboração. A letra “ $h$ ” em nada afeta a palavra falada, pois não é audível no português quando adicionada dessa maneira. Mas o texto aqui é imagem de leitura, e o "h" marca a passagem.

<http://jorgemennabarreto.blogspot.com/2009/12/projeto-materia.html>

2 Le Clézio, J.M.G. In: HELDER, Herberto. As Magias. Lisboa, Portugal: Ed. Assírio \& Alvim, 2010, p.10. 
Além das hobras, também revisito três traduções interlinguísticas de minha autoria que já tem circulado em revistas especializadas. São elas: Um lugar após o outro: anotações sobre o site specificity (Revista de Pós-Graduação da UFRJ, 2008), de Miwon Kwon; O lugar errado (Revista Urbânia, 2008), da mesma autora; e $A$ arte de ser testemunha na esfera pública dos tempos de guerra (Revista de Pós-Graduação da UERJ, 2009), de Rosalyn Deutsche. Tais traduções foram realizadas inicialmente como uma estratégia de acercamento e leitura meticulosa dos textos, motivadas pela pesquisa que desenvolvi durante o mestrado e o doutorado. Além delas, também retomo a minha dissertação de mestrado - Lugares Moles, defendida em 2007 na ECA-USP - propondo uma revisão crítica de alguns dos temas e obras tratados então. Por ocasião da tese, incluído como anexo, traduzi o texto de Hito Steyerl, Estética da Resistência? Pesquisa artística como Disciplina e Conflito (2011), ainda não publicado. Esse último, e mais atual, informa a concepção de pesquisa artística deste trabalho.

O desfecho apoia-se na hobra de minha autoria chamada Desleituras (2011), que foi projetada e realizada durante a escrita da tese e herda grande parte de sua problemática, com a devida refração. Será trabalhada e analisada na conclusão, abrindo uma outra perspectiva para os problemas tratados e adensando a sua consistência, a partir de um novo bolhar.

\section{Anotações}

+ As chamadas Anotações, encontradas no final de alguns dos capítulos, são elaborações tardias que não se encaixaram na linearidade do texto principal, mas que insistem em estar presentes. São fruto do incessante exercício da releitura, formadas por citações, insights, comentários e fragmentos que complementam ou desestabilizam o texto que veio antes, afirmando assim também um estado constante de abertura e inacabamento. 
encontrado ouvidos para escutar a música do fundo da água.

Não é como os outros, este poema, não distrai, não se esquiva. Na verdade não está escrito, encontra-se ali na página por acidente, e deve estar também algures, gravado numa árvore, por exemplo, ou inscrito na terra seca, ou tatuado então na pele humana. Claro que não está apenas escrito. Passou pelo tremor da escrita, foi assim que apareceu primeiro. Mas não 


\section{INTRODUÇÃO}

Quando esta tese começa? Certamente que não nesta página. Talvez a pergunta seja: Quando a tese começou a se formar? Pergunta importante, por mais que a questão da origem, ou de uma origem estável, seja algo que buscarei desconstruir nas próximas páginas. Sendo assim, adotarei temporariamente o exercício errante da memória para detectar alguns dos primeiros movimentos perceptíveis do problema apresentado ou para identificar o seu contexto; e por isso, a segunda pergunta feita acima é mais apropriada, porque diz respeito à formação.

A tese começou a se formar a partir do meu ingresso no ambiente acadêmico: a graduação em Artes Plásticas em 1991 na Universidade Federal do Rio Grande do Sul. Método frequente na discussão de exercícios realizados em disciplinas práticas era a associação da produção dos alunos - uma pintura, um desenho, uma instalação, etc. - a algum autor ${ }^{3}$ prévio que os tivesse antecedido na abordagem das questões propostas. Tal referência - como costumava ser chamada - era fornecida espontaneamente a partir do repertório do professor. Em uma espécie de salto na história ${ }^{4}$, buscava artistas e obras que poderiam ser relacionados ao que ali estava posto. Em geral, as aproximações eram feitas por afinidades, formais ou entre procedimentos. Ao começar a trabalhar com figuras humanas em gesso, modeladas a partir do próprio corpo, logo fui informado sobre a existência do artista inglês Anthony Gormley (1950), por exemplo.

A referência chegava aos meus ouvidos com notas ambivalentes. Se por um lado fazia sentir-me reconhecido e compreendido, produzindo fortalecimento para um pensamento em formação, por outro ofuscava o frescor da descoberta, desfazendo o sonho de

3 A concepção de autor que utilizo é ampla, podendo incluir artistas, cineastas, poetas e escritores, por exemplo. Muitas vezes será usada como sinônimo de "artista”, para que a palavra não se torne excessivamente repetitiva.

4 A ideia de um salto na história é proposta por Walter Benjamin (Gagnebin 2009) a partir do seu conceito de origem: Ursprung. Será desenvolvido mais adiante na introdução. 
inovação, ou adiando-o para um futuro incerto. A ambiguidade do sentimento perpetuava-se ao dar-me conta de que havia um preço a ser pago pela interlocução, pelo deixar-se ler: a perda do sentimento de originalidade.

A posição ocupada pelo professor era então a daquele que, a partir do ato da leitura (da produção do aluno e da tradição) acendia a luz e desiludia, deseuforizava o processo de criação, inserindo assim a reflexão do aluno em uma rede já historicizada e produzindo recortes na história do pensamento artístico e poético ${ }^{5}$. Restava observar e aprender com o recém-descoberto antecessor, assumir a filiação, mas não sem um processo de angústia ${ }^{6}$ de um artista em formação. Seria capaz um dia de produzir algo de equivalente relevância? Conseguiria construir uma identidade artística reconhecida? Como tornar-me um autor, com voz própria?

O conflito serviria como combustível para estudar e embrenhar-me no discurso alheio, ampliar o repertório, para daí então encontrar a possibilidade do novo, não mais a partir de uma voz original - umbigada e inspirada - mas daquela que nasce em relação, em resposta, e considera o contexto no qual se insere. Nessa linha, a consciência do artista diante do circuito onde se posiciona tem sido uma das características do entendimento atual do artista enquanto pesquisador. $\mathrm{Na}$ recente publicação organizada sobre o assunto, Janneke Wesseling afirma,

O artista posiciona a sua obra no contexto formado por outras obras de arte, está situada vis-à-vis outros trabalhos de arte. Isto não quer dizer que estas outras obras sejam literalmente identificáveis no novo trabalho (embora possa acontecer). Trabalhos de arte incorporam um meta-elemento,

5 É interessante notar a diferença da formação de repertório entre as disciplinas práticas e as teóricas do curso de artes. Enquanto as revisitas à tradição são feitas a partir da produção do aluno nas aulas práticas, as teóricas costumam seguir uma narrativa cronológica, a partir da chamada "história oficial”.

6 No livro Angústia da Influência, Harold Bloom (1930) desenvolve uma "teoria da influência poética”, investigando as complexas relações entre um poeta e os seus precursores. O sentimento predominante que resulta é o da angústia, que dá título ao livro. Será analisado em seguida. 
um momento conceitual; o trabalho de arte tem "consciência" de si mesmo, de sua própria posição. Poder-se-ia nomear isso de "autoconsciência" da obra de arte, que questiona e comenta a si mesma, assim como o trabalho de outros artistas. ${ }^{7}$

A aproximação de ambientes de formação decorrente do conflito descrito foi o dos ateliês da escola com o da biblioteca. O que se instaurava era uma torção gradual no olhar, ávido por fazer, criar, construir e modelar, o qual era convocado a observar, ler, pesquisar e responder. Inseria-se, nesse giro, uma outra temporalidade, inclusiva de um pensamento alheio. Começava a se formar o artista-leitor ${ }^{8}$.

\section{O artista-leitor}

O termo leitura é mais frequentemente associado ao texto, à literatura. No entanto, também tem sido utilizado em arte para referir-se à análise de uma obra visual. O seu uso ganhou uma conotação mais literal a partir da aproximação intensiva entre as práticas visuais e as discursivas, que marca a produção contemporânea a partir de 1960 com a arte conceitual. Questionando as ideias de visibilidade (na esteira do não-retiniano de Marcel Duchamp) e muitas vezes substituindo-as por noções de legibilidade, muitos artistas contemporâneos têm proposto um outro modo e temporalidade na relação que estabelecem

7 No original: The artist places every work of art in the context of other works of art, it is positioned vis-à-vis other works of art. This does not imply that those other works of art are litterally indentifiable in the new work (though that may be the case). Works of art embody a meta-element, a conceptual moment; the work os art is "aware" of itself, of its own position. One might term this the "self-awarness" of works of art, which question and comment on themselves and the art of the others. WESSELING, Janneke (ed.). See it again, say it again: the artist as researcher. Amsterdam: Ed. Antennae, 2011, p.6.

$8 \mathrm{O}$ artista hifenizado, que agrega uma nova atribuição/característica/função à sua denominação, foi inspirado no conceito de artista-etc., de Ricardo Basbaum, cujos exemplos incluem: artista-curador, artista-professor, artista-crítico, etc. (Basbaum 2004). 
com o espectador, frequentemente tornado leitor 9 . Dos muitos desdobramentos possíveis do tema, interessa neste momento dar ênfase à especificidade da leitura feita pelo artista (ou pelo olhar poético) dos seus precursores ${ }^{10}$. No âmbito da literatura, o crítico Harold Bloom (1930) introduz o termo misreading para caracterizar a propriedade transgressora da leitura feita por um poeta de seus antecessores. Arthur Nestrovski traduziu o termo por desleitura. A ideia carrega uma qualidade de desvio ou como Bloom caracteriza, clinamen:

Clinamen é a desleitura, ou a desapropriação poética propriamente dita; a palavra vem de Lucrécio, onde significa um "desvio" dos átomos, que torne possível qualquer mudança no universo. Um poeta se desvia ao ler um poema do seu precursor de tal forma a executar um clinamen em relação a ele (Bloom 1991: 43).

Ao traduzir misreading por desleitura, Nestrovski logra aproximar o termo de desvio, por compartilharem o mesmo prefixo. Poder-se-ia dizer que esta é uma possibilidade oferecida pela tradução, já que o original não guarda semelhança gráfica entre swerve [desvio] e misreading [desleitura]. Para Bloom, os poetas fortes - como denomina aqueles que realizam um desvio, e não apenas admiram a tradição - "não lêem necessariamente da mesma forma como mesmo os mais fortes dos críticos” (Bloom 1991: 49). E continua: "Os poetas não são os leitores nem ideais nem comuns,...", referindo-se a

9 Para uma análise aprofundada da questão, principalmente no tensionamento que a ideia de leitura provoca na recepção da arte contemporânea, ver o artigo Situações de Leitura na Arte Contemporânea . SANTOS, Maria Ivone dos. Situações de Leitura na Arte Contemporânea. Revista Palíndromo 2 CEART/UDESC. Capturado em $1^{\circ}$ dez. 2011. Online. Disponível em: <http://ppgav.ceart.udesc.br/revista/ edicoes/2processos_artisticos/2_palindromo_santos.pdf>

10 O curador Nicholas Bourriaud situa toda uma geração de artistas, a partir da década de 1990, cuja produção parte da apropriação de obras realizadas por outros autores. No entanto, sua ênfase está mais na ideia do "artista enquanto consumidor", ou do que denomina cultura do uso, do que na problematização mais cuidadosa do ato da leitura, objetivo desta tese. Ver BOURRIAUD, Nicolas. Post produccion. Buenos Aires, Argentina: Ed. Adriana Hidalgo, 2004. 
uma leitura que não está comprometida com uma suposta ideia de "justiça” ou "avaliação precisa”, papel mais frequentemente associado à crítica. De acordo com Bloom: “A disjunção experienciada pelo poeta 'em cada leitor', a disjunção do leitor como poeta com relação àquilo que lê, não é necessariamente a mesma experienciada pelo leitor enquanto crítico" (Bloom 1991: 56).

A desleitura está na base da formação do artista-leitor, como um átomo desobediente que, num dado momento, afasta-se da órbita comum e traça um desvio. Afirma-se assim um modo de ver deslizante, inclinação do olhar que constrói este trabalho, diferente do ponto de vista de um historiador, crítico ou acadêmico, na acepção mais conservadora dos termos. É portanto uma mirada específica a que proponho, comprometida com e pelo clinamen. Nas palavras do próprio Lucrécio (99 A.C - 55 A.C.):

Quando átomos se movem para baixo através do vazio pelo seu próprio peso, desviam um pouco em um tempo e espaço incertos, apenas o suficiente para que se possa dizer que seu movimento mudou. Mas se não tivessem o hábito de se desviar, todos cairiam direto através das profundezas do vazio, como gotas de chuva, e nenhuma colisão ocorreria, tampouco qualquer golpe seria produzido entre os átomos. Nesse caso, a natureza nunca teria criado nada. ${ }^{11}$

A ideia de um desvio criador, fornecida pela concepção de clinamen, é rica para pensar a maneira como o artista, ou poeta, se apropria da tradição. No entanto, a noção

11 Lucrécio foi um poeta e filósofo romano, cuja única obra conhecida é Sobre a Natureza das Coisas, um tratado sobre a filosofia epicurista na forma de poema. Nela, "Lucrécio apresenta a teoria de que a luz visível seria composta de pequenas partículas. Teoria incompleta, apesar de bastante consistente, é uma espécie de visão antiga da atual teoria dos fótons. Também neste poema, Lucrécio sustenta a idéia da existência de criaturas vivas que, apesar de invisíveis, teriam a capacidade de causar doenças. Esta idéia representa na realidade a base da microbiologia." Seu conceito de clinamen já foi usado por diversos autores, além de Harold Bloom, com diferentes interpretações. Entre eles: Simone de Beauvoir, Jacques Lacan, Jacques Derrida, Jean-Luc Nancy, Alain Badiou, Gilles Deleuze e Michel Serres. Verbete capturado em 15 dez. 2011. Online. Disponível em: < http://en.wikipedia.org/wiki/Clinamen> 
de que isso aconteça de forma gratuita ou espontânea, como na descrição de clinamen, é contraproducente. A concepção de desvio - conforme a utilizo aqui - não é casual ou natural. É fruto de um olhar intenso que possibilita entrar em relação forte com o outro e gerar o conflito necessário para que o desvio ocorra.

\section{Leitura forte e tradução}

A articulação entre presente e passado, que ocorre a partir da figura do artista ocupado com a leitura dos seus antecessores, deságua na concepção de tradução que abordarei na tese. A prática do tradutor está explícita e inevitavelmente entrelaçada com o passado histórico, já que a própria matéria sobre a qual reflete lhe antecede no tempo. Para Susana Lages: "Se a apropriação de textos anteriores é consubstancial à atividade do filósofo, do escritor, enfim, do intelectual em geral, para o tradutor, ela é a premissa concreta, a origem e a possibilidade mesma de seu trabalho" (Lages 2002: 35). No entanto, o que se busca na anterioridade é uma leitura que a renove, distante da ideia do resgate de uma suposta verdade fixa e essencial ali contida. De acordo com Walter Benjamin: "Articular historicamente o passado não significa conhecê-lo 'como ele de fato foi'. Significa apropriar-se de uma reminiscência, tal como relampeja no momento de um perigo"12.

É na tradução que a "alteridade na tradição” mais claramente se revela, num jogo dialético e perigoso entre o "reconhecimento do outro e a afirmação de si”. Perigoso pois, na medida em que o outro é depositário da minha admiração, corro o risco de apagar a mim mesmo no ato tradutório para melhor deixá-lo falar. É o risco de, ao reconhecer a estatura daquele que admiro, ser "devorado" pela sua obra ${ }^{13}$; “em vez de se apropriar, ser apropriado” (Lages 2002: 36). No entanto, é a experiência arriscada com o passado que

12 BENJAMIN, Walter. Sobre o conceito de história. Capturado em 5 dez. 2011. Online. Disponível em: <http://rae.com.pt/wb2.pdf>

13 As citações acima, no mesmo parágrafo, referem-se a mesma fonte : GAGNEBIN, Jean-Marie. Apud cit: LAGES, Susana, 2002, p. 15. 
torna possível a in(ter)venção no presente ${ }^{14}$, produzindo uma consciência histórica, atualizando a tradição de forma crítica e prolongando a sua vida ${ }^{15}$.

Tresler, tresluzir, transluzir e transluminar ${ }^{16}$ são alguns do termos forjados pelos poetas concretos brasileiros - Haroldo de Campos, Augusto de Campos e Décio Pignatari - para caracterizar uma tradução irreverente, criativa e até mesmo abusiva ${ }^{17}$. Defendem a traição ao original como ato de violência necessário à preservação de uma tradição viva (Lages 2002: 92), contrariando com bom humor a ideia de uma tradução servil que se apaga enquanto obra diante do original. Dito de outra forma, o movimento da poesia concreta previa uma inversão da relação hierárquica entre autor traduzido e tradutor. A relação entre os concretistas, a "leitura forte" de Harold Bloom e tradução foi proposta por Susana Lages:

Pode-se dizer que o projeto e a prática não só da tradução concretista, mas do comentário sobre a própria tradução, realizam aquilo que o crítico literário americano Harold Bloom denomina uma leitura forte. Para Bloom, os grandes poetas são aqueles que, em seu contato, sempre conflitivo, com os antecessores na tradição, conseguem realizar uma apropriação tão radical a ponto de sua obra modificar a interpretação que posteriormente será feita de seus precursores (Lages 2002: 91).

Julio Plaza, “artista-tradutor” (Plaza 1984: 6) - cuja pesquisa sobre o assunto foi

14 GAGNEBIN, Jean-Marie. Apud cit: LAGES, Susana, 2002, p. 17.

15 A relação da tradução com a "sobrevida" (Überleben) do original é tratada por Walter Benjamin. BENJAMIN, Walter. A tarefa do tradutor. GAGNEBIN, Jeanne-Marie (org.). Escritos sobre Mito e Linguagem (1915-1921). São Paulo: Ed. 34, 2011, p. 104.

16 MAGALHÃES, Celia. Tradução e Transculturação: a teoria monstruosa de Haroldo de Campos. Capturado em 05 dez. 2011. Online. Disponível em: < http://www.journal.ufsc.br/index.php/traducao/article/ download/5384/4927>

17 DERRIDA, Jacques. La traduction doit abuser. Apud cit: LAGES, Susana, 2002. p. 79. 
fortemente influenciada pelos poetas concretos e com os quais colaborou - entende que: “qualquer pensamento é necessariamente tradução" (Plaza 1984: 20). Isto ocorre, pois: "qualquer pensamento requer ter havido outro pensamento para o qual ele funciona como interpretante" (Plaza 1984: 20). Considerando as colocações, é possível reconhecer não somente a anterioridade e exterioridade de toda produção de sentido, mas também abalar o mito da interioridade, baseado na ideia de um sujeito absoluto - que ainda assombra a produção artística - derivada das noções de inspiração e gênio modernos.

A relação assumida com a tradição, a bibliografia e toda uma antexterioridade é algo marcante no percurso acadêmico, seja como aluno, pesquisador ou professor. Para o artista na academia, existe o temor de afastar-se de sua plástica para se aproximar das letras, do texto, o que tornaria a prática artística impura. No momento em que toma uma consciência aguda do seu fazer, de sua filiação, da exterioridade (e não-genialidade) que permeia toda a produção intelectual contemporânea, a pureza visual ${ }^{18}$ é posta em cheque. Talvez haja de fato uma melancolia perigosa que ronda aquele que entra em contato com a teoria e a tradição, que pode intimidar e assombrar pelo peso. A leitura forte e a tradução são portanto aliadas fundamentais na jornada acadêmica do artista. $\mathrm{O}$ peso melancólico, que também ancora, é inevitável, mas apenas como parte (importante) de um processo mais amplo. $\mathrm{O}$ ato da tradução, temperado pela irreverência do pensamento poético, é capaz de somar influxos antropofágicos aos melancólicos, na busca de uma: "tradução alegre, irreverente, audaciosa, mesmo violenta, enfim, uma tradução sem melancolia” 19 .

18 Embora a expressão pureza visual remeta às bases do modernismo e ao processo social de higienismo que lhe sustenta, o uso que faço da expressão aqui diz respeito, mais especificamente, ao processo de hibridação entre arte e texto. Dessa maneira, se aproxima das reflexões do artista-escritor Ricardo Basbaum, cuja pesquisa tem se dedicado intensamente aos "encontros e confrontos permanentes entre imagem e palavra". LUZ, Rogério. In: BASBAUM, Ricardo. Além da pureza visual. Porto Alegre: Editora Zouk, 2007, p. 10.

19 GAGNEBIN, Jean-Marie. Apud cit: LAGES, Susana, 2002. p. 14. 


\section{Arte como pesquisa e pesquisa como arte}

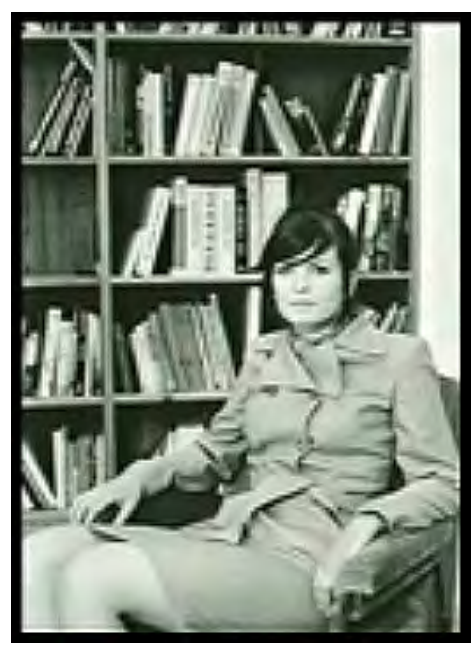

Still do vídeo da palestra de Dieter Roelstraete sobre a artista Goshka Macuga.
Relacionada à ideia do artista-leitor, assim como ao próprio ambiente acadêmico onde se dá esta reflexão, está o elo problemático entre arte e pesquisa. Em palestra recente sobre a obra da artista Goshka Macuga (1967), o curador e filósofo Dieter Roelstraete discorreu sobre a relação entre a produção da artista e a noção atual de arte como pesquisa e pesquisa como arte. Para ilustrar seu pensamento, o curador usou um retrato da artista posando diante de uma estante de livros, sua própria biblioteca:

Já faz bastante tempo desde que vimos um retrato de um artista com seus pincéis no ateliê. Já nos acostumamos a ver o artista como alguém com um papel mais administrativo, que veste uma gravata...o artista como um trabalhador imaterial, mais do qualquer coisa [...] esta foto mostra a artista em frente ao, talvez, seu kit de ferramentas mais importante, a biblioteca [...] é também uma das razões pela qual eu, como filósofo, tenho tanto interesse no trabalho, porque há tanto para ler nele, e os livros têm um papel essencial no projeto e na pesquisa, que de uma certa forma está ancorado em bibliotecas. ${ }^{20}$

A imagem e o comentário retratam a aproximação crescente que tem sido feita entre a arte contemporânea e a concepção de pesquisa, embora Roelstraete permaneça cético e alerte para o risco de uma academicização do mundo da arte. Ao mesmo tempo,

20 Palestra realizada por Dieter Roelstraete no Walker Art Center, Minneapolis, EUA em 2011. No original: It's been a long time since we last saw a portrait of the artist with his brushes in his studio. We have long become accostumed to seeeing the artist as a more managerial type, wearing a tie... the artist as an imaterial labourer, more than anything else [...] this picture portrays the artist in front of perhaps her most important tool kit, namely library [...] it's also one of the reasons why I, myself as a philosopher, am so interested in the work, because there's so much to read in it, and books play such an essential part of the project and research, that is anchored in a way in libraries. Capturado em 07 dez. 2011. Online. Disponível em: <http://www. youtube.com/watch?v=eu_RzPnnfb4\&list=FLiOUASkTZRw4p_vvZgemcrw\&index=11\&feature=plpp > 
ao visitar estúdios de artistas, tem perguntado sobre o que têm lido e demonstrado um interesse especial por suas bibliotecas. No artigo The Way of the Shovel (2011), o curador associa a figura do artista contemporâneo àquela de um historiador, ou mesmo um arqueólogo, cujas investigações tratam de "escavar" a história de um determinado assunto, ou até mesmo, literalmente, um local ${ }^{21}$. De acordo com Roelstrate, a pulsão revisionista, ou o culto à memória, poderia ser chamada de uma "virada historiográfica" da arte contemporânea, que estaria na base do seu entendimento enquanto pesquisa ${ }^{22}$. $\mathrm{O}$ autor usa como ilustração do seu texto uma foto da obra Fieldwork (2003), de Jeff Wall, na qual o artista documenta um processo de escavação de um sítio arqueológico no Canadá. Sobre uma outra obra do mesmo artista, Morning Cleaning, Mies van der Robe Foundation, Barcelona (1999), a pesquisadora Christine Conley associa a prática de Wall àquela do Grübler de Walter Benjamin ${ }^{23}$. De acordo com Jeanne Marie Gagnebin, a palavra Grübler no alemão "significa o sujeito ocupado a grübeln, verbo que pode ser traduzido por sonhar, meditar, matutar, ruminar e cuja etimologia reenvia a graben, cavar $[\ldots . .]^{24}$.

Termos como research-based art, artistic research e art as research (ou research as art) têm sido utilizados com frequência no meio artístico internacional para definir uma

21 Como epígrafe de seu texto, Roelstraete usa uma citação atribuída a Walter Benjamin: “Aquele que busca abordar seu próprio passado enterrado, deve agir como um homem que escava”. ROELSTRATE, Dieter. The Way of the Shovel. Online. Disponível em: <http://www.e-flux.com/journal/the-way-of-the-shovel-on-the-archeological-imaginary-in-art/>

\section{Ibid.}

23 A obra consiste em um backlight com uma fotografia em alta resolução que mostra uma "imagem do pavilião da Alemanha projetado por Mies van der Rohe [...]”. Ver CONLEY, Christine. Capturado em 08 jan. 2012. Online. Disponível em: <http://www.essex.ac.uk/arthistory/ahrc/speakers.htm>

24 Citação completa: "A palavra Grübler significa o sujeito ocupado a grübeln, verbo que pode ser traduzido por sonhar, meditar, matutar, ruminar e cuja etimologia reenvia a graben, cavar, e a Grab, túmulo; trata-se portanto de um matutar ou um meditar ligado ao sem fundo e à morte: no contexto de $A$ Origem do Barroco Alemão,( WALTER. Benjamin. 1984, p.198), à meditação infinita e melancólica do alegorista. Sérgio Paulo Rouanet traduz Grübler por “o meditativo””. GAGNEBIN, Jeanne-Marie, apud. cit. LAGES, 2002, p.14. 


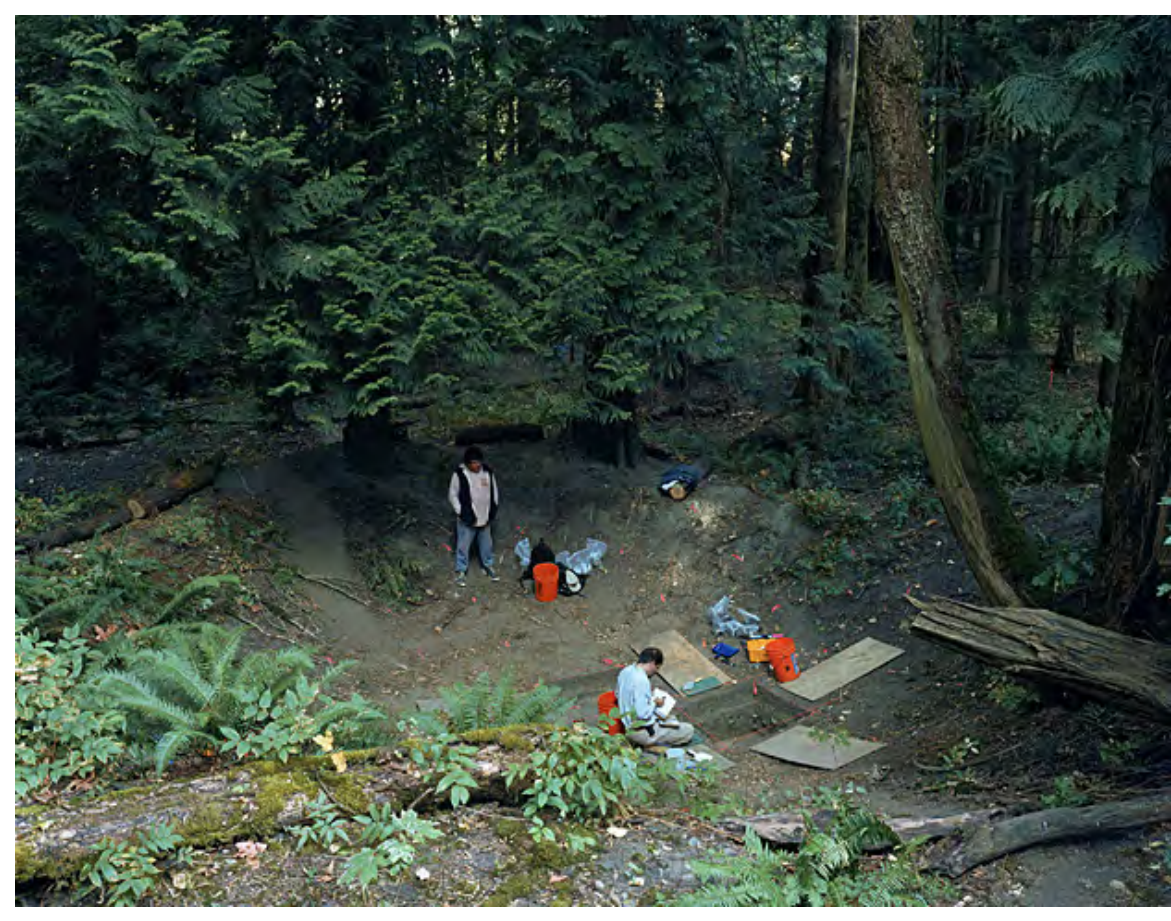

Fieldwork, 2003, Jeff Wall.

tendência, ou supostamente legitimar a atualidade de uma prática ${ }^{25}$. “Mas o que é a pesquisa artística hoje?" é a pergunta inicial do artigo Estética da Resistência? Pesquisa artística como Disciplina e Conflito (2010) da artista e pesquisadora europeia Hito Steyer ${ }^{26}$. $\mathrm{Na}$ tentativa de responder a sua própria pergunta, Steyerl instiga:

No presente, ninguém parece saber a resposta para esta pergunta. A pesquisa artística é tratada como uma das múltiplas práticas que são definidas pela indefinição, constantemente em fluxo, sem coerência e identidade. Mas e se essa visão estivesse equivocada? E se soubéssemos mais do que imaginamos sobre o assunto? Para discutir esta proposição, vamos primeiro olhar para os debates atuais em torno da ideia de pesquisa artística. Parece que uma das preocupações mais importantes é a transformação da pesquisa artística em uma disciplina acadêmica. Há discussões sobre currículo, graus, método, aplicação prática e pedagogia. Por outro lado, há também uma crítica substancial a esta abordagem. Endereça-se à institucionalização da pesquisa artística como sendo cúmplice dos novos modos de produção dentro do capitalismo cognitivo: educação como mercadoria, indústrias criativas e afetivas,

25 A revista Text zur Kunst dedicou um número inteiro a este assunto (junho 2011). De acordo com o editorial, o tópico Artistic Research "tem sido discutido de maneira crescente nas últimas duas décadas, particularmente nos programas de pós-graduação. Na educação universitária e acadêmica, há sinais de uma tendência que determina a arte como um campo de 'pesquisa' - a pesquisa artística é portanto um ponto de referência altamente controvertido nas iniciativas relacionadas aos programas educacionais de de pesquisa, mesmo que as precondições históricas e sistemáticas desse tipo de 'pesquisa' ainda sejam pouco claras." Revista Text zur Kunst. Berlim, 2011, p. 6 (tradução minha). Ver também a revista Art and Research. Online. Disponível em: <http://www.artandresearch.org.uk/>

26 O texto foi originalmente publicado na Mahkuzine 8, inverno 2010. Online. Disponível em: $<w w w$. mahku.nl/download/maHKUzine08_web.pdf $>$. Traduzido por mim do inglês para o português, com autorização da autora em 2011. Está anexado à tese. Hito Steyerl é artista e professora na Universidade de Arte de Berlim. 
estética administrativa, entre outros. Ambas perspectivas concordam em um ponto: a pesquisa artística no presente tem sido constituída como uma disciplina acadêmica mais ou menos normativa ${ }^{27}$.

Para a autora, o fenômeno pode ser entendido a partir de duas perspectivas. Primeiramente, como disciplina, "a pesquisa artística parece mais ou menos confinada à academia de arte contemporânea e metropolitana”, associada a práticas de artistas que vêm atuando como "etnógrafos, sociólogos e designers sociais e de produto". Tal tendência dá a “impressão de ser uma propriedade valiosa do tecnológica e conceitualmente avançado capitalismo do Primeiro Mundo, tentando melhorar a sua população para funcionar de maneira eficiente numa economia do conhecimento, e como subproduto, casualmente pesquisando o resto do mundo também”. No entanto, há uma outra vertente identificada por Steyerl, mais descentralizada e ligada às lutas sociais e ao conflito, "que já foi entendida como uma estética da resistência”, título do livro de Peter Weiss citado pela autora. O livro "usa explicitamente o termo 'pesquisa artística [künstlerische Forschung]' para referir-se a práticas como a de Brecht escrevendo em exílio, apresentando uma leitura alternativa da história da arte, tal como um relato da história da resistência antifascista de 1933 a $1945 "$.

Entre o conflito e a disciplina, assim como entre a língua do singular e a do específico, valor de uso e valor de troca, a autora entende que a "pesquisa artística seja um ato de tradução" e que "fala muitas línguas ao mesmo tempo." Nesse sentido, ao mesmo tempo em que discorre sobre as posições de disciplina e conflito na pesquisa artística, aborda uma obra de sua própria prática enquanto artista que traduz a discussão em voga. Em The Building (2009), a artista realizou uma investigação sobre a construção de um prédio histórico na praça principal de Linz, na Áustria. Para a autora, "há pelo menos duas maneiras diferentes de descrever este prédio. Pode ser dito que as pedras mesmas usadas na construção ganharam a sua forma de acordo com o paradigma da arquitetura

27 STEYERL, Hito. Estética da Resistência? Pesquisa artística como Disciplina e Conflito, 2010. Em anexo. Todas as citações a seguir referem-se ao mesmo texto. 
neoclássica, que seria a descrição oficial dada sobre o edifício em si. Ou as pedras podem ser descritas como tendo sido, provavelmente, trabalhadas por um pedreiro no campo de concentração Mauthasen, e que era talvez um ex-lutador da Espanha Republicana”. As duas formas carregam em si diferentes qualidades: "a mesma pedra pode ser descrita pelo ponto de vista da disciplina, que classifica e nomeia. Mas também pode ser lida como um rastro de um conflito suprimido". O estudo de caso proposto por Steyerl torna-se ainda mais relevante ao agregar o fato de que tal prédio abriga hoje a Academia de Arte de Linz, onde há um departamento dedicado à pesquisa artística.

No Brasil, a relação entre arte e pesquisa também tem sido motivo de debate, especialmente no meio acadêmico e órgãos de financiamento ${ }^{28}$. Muitos dos atores envolvidos na discussão (artistas e teóricos) "entendem que não há sentido em se falar de pesquisa em arte, pois, segundo eles, toda arte, pela sua própria natureza, é pesquisa, daí não caber distinções" (Zamboni 2006: 8). No entanto, de acordo com Silvio Zamboni, pesquisador no assunto, o que existe são "formas distintas de processar o trabalho de arte. Ou seja, há artistas que realizam de forma nitidamente consciente pesquisa em arte, e artistas que trabalham de forma preponderantemente intuitiva, e afastam-se, ipso facto, de um processo de labor com alto grau de conscientização, conduta requerida por qualquer processo de pesquisa racional” (Zamboni 2006: 8). Assim, é possível distinguir a pesquisa como meio para se chegar a uma obra, cujos rastros são apagados uma vez que está pronta, e a pesquisa que evidencia o seu processo e inclui os seus métodos como conteúdos a serem analisados. Tal é o caso de Hito Steyerl que constrói um texto reflexivo sobre as próprias bases teóricas do artista enquanto pesquisador como parte do processo de elaboração de seu projeto. Para além do conteúdo histórico embutido na obra, seu olhar também se debruça sobre a própria pesquisa como um objeto a ser debatido. É a qualidade crítica-reflexiva do pensamento da autora que inspira a tradução que realizei para o português e a sua inclusão como anexo da tese.

28 Para uma consideração da relação entre arte e universidade no Brasil, ver o dossiê Arte e universidade: uma relação conflituosa? Revista Trópico. Online. Disponível em: <http://pphp.uol.com.br/tropico/html/ textos/2379.1shl> 


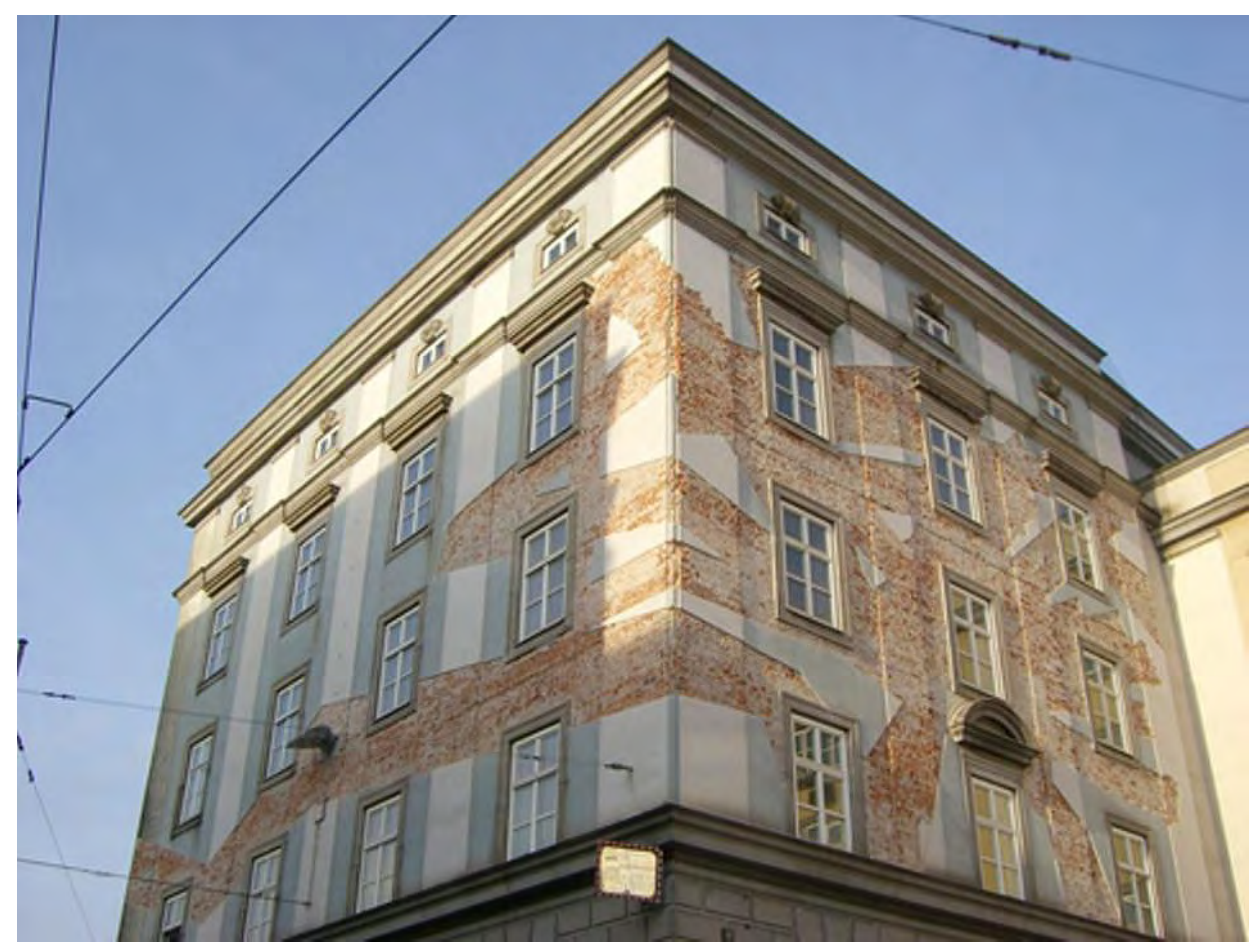

The Building, 2009, Hito Steyerl.

\section{Pesquisa, site specificity e tradução}

A investigação de Hito Steyerl resultou em uma obra instalada no próprio prédio que fora o foco da pesquisa, descrita da seguinte maneira:

The Building [Der Bau] confronta o prédio com o seu entorno, mostrando documentação de arquivo, evidencias materiais e entrevistas. A história é contada em cinco monitores de vídeo, instalados no espaço comercial do prédio. Um desenho foi cavado na fachada do prédio - dirigido pelo arquiteto Gabu Heindl - que mostra as trajetórias dos protagonistas da história pelo mundo. Remove-se a camada de cimento para revelar um mapa simbólico do trabalho forçado, do desterro e da anulação ${ }^{29}$.

Uma outra maneira de abordar o projeto The Building é considerando as relações de especificidade que a investigação estabelece com o lugar que a abriga. A partir de uma pesquisa atenta de uma determinada localidade, a Academia de Arte de Linz, a artista propõe uma resposta que constrói outras possibilidades de leitura do prédio. Além de ser um projeto de pesquisa artística, a complexidade da relação que a investigação estabelece com o lugar possibilita descrevê-lo também enquanto um projeto site-specific, tema de minha dissertação de mestrado $(2007)^{30}$.

29 A descrição e imagens da instalação podem ser encontradas Capturada em 04 jan. 2012. Online. Disponível em: <http://www.archello.com/en/project/building>

30 Ver MENNA BARRETO, Jorge. Lugares Moles (229pgs.). Dissertação de Mestrado em Artes Plásticas/ Poéticas Visuais, ECA-USP, São Paulo, 2007. 
O termo site-specific começou a ser usado em arte no final da década de 1960, durante o Minimalismo estadunidense, para referir-se a obras pensadas especificamente para uma dada localidade. As primeiras manifestações do site specificity dirigiam-se predominantemente às características físicas ou arquitetônicas do lugar onde eram instaladas. Aos poucos, as relações da obra com o local se tornaram mais complexas, passando a considerar as camadas históricas, sociais e institucionais. Em práticas mais recentes, a ideia de lugar se desmaterializa a tal ponto de virar um discurso, um dado histórico ou uma questão teórica. Tal é a hipótese da historiadora Miwon Kwon, que cunha o termo site discursivo para caracterizar a concepção de lugar atuante nas práticas mais atuais ${ }^{31}$. É questionável, no entanto, o quanto o alargamento da ideia de lugar (site), para abranger praticamente qualquer coisa, dá conta de relacionar práticas artísticas mais recentes com as primeiras abordagens do site specificity. Ainda, seria viável insistirmos na denominação site-specific para definir práticas que atuam sobre uma ideia de lugar tão esgarçada (e inespecífica!) como uma questão ecológica, por exemplo? A obra do estadunidense Mark Dion é uma das referências de site discursivo para Kwon. O artista, ao endereçar-se a questões ecológicas em sua obra, estaria portanto situando o seu trabalho no debate da discussão ecológica, entendido como um lugar [site] pela autora, e portanto caracterizando a sua prática como site-specific ${ }^{32}$.

A questão levantada por Miwon Kwon é legítima no seu intuito de buscar um lastro histórico para aquelas práticas artísticas mais atuais que poderiam ter sido influenciadas pelo legado do site specificity. Questionável é localizar a discussão sobre uma tipologia do lugar e o seu gradual processo de desmaterialização. Práticas artísticas mais recentes não consideram necessariamente uma tipologia do lugar. Forçar-lhes uma relação com uma suposta ideia de site termina por ofuscar outras relações possíveis com o seu legado, outras possibilidades de atualizar, ou traduzir, a concepção de site-specific. Relacionado

31 No livro One place after another, a autora cria uma genealogia do site specificity, começando pelo literal site (do Minimalismo), institutional-critique and discursive site. KWON, Miwon. One place after another. EUA: Ed. MIT Press, 2002.

32 Ver KWON, Miwon. Um lugar após o outro: anotações sobre o site-specificity. Arte E Ensaios 17. Revista do Programa de Pós-Graduação em Artes Visuais, EBA, UFRJ, 2008 (trad. Jorge Menna Barreto). 
à tradução do termo, parte importante de minha pesquisa de mestrado consistiu em uma dobra do conceito implicado pelo termo site-specific sobre ele mesmo. Ou seja, defendi a ideia de que a expressão site-specific e suas especificidades culturais, históricas e linguísticas são determinantes para a construção do seu sentido. Seu uso no Brasil, sem tradução alguma, como apenas mais uma categoria artística - trai portanto o conceito fundamental implicado pelo termo: “o contexto define o significado”. Baseando-me assim em práticas site-specific - que requerem uma reelaboração quando se deslocam, pois não têm autonomia em relação ao seu contexto - sugeri a tradução do termo para o português, ou

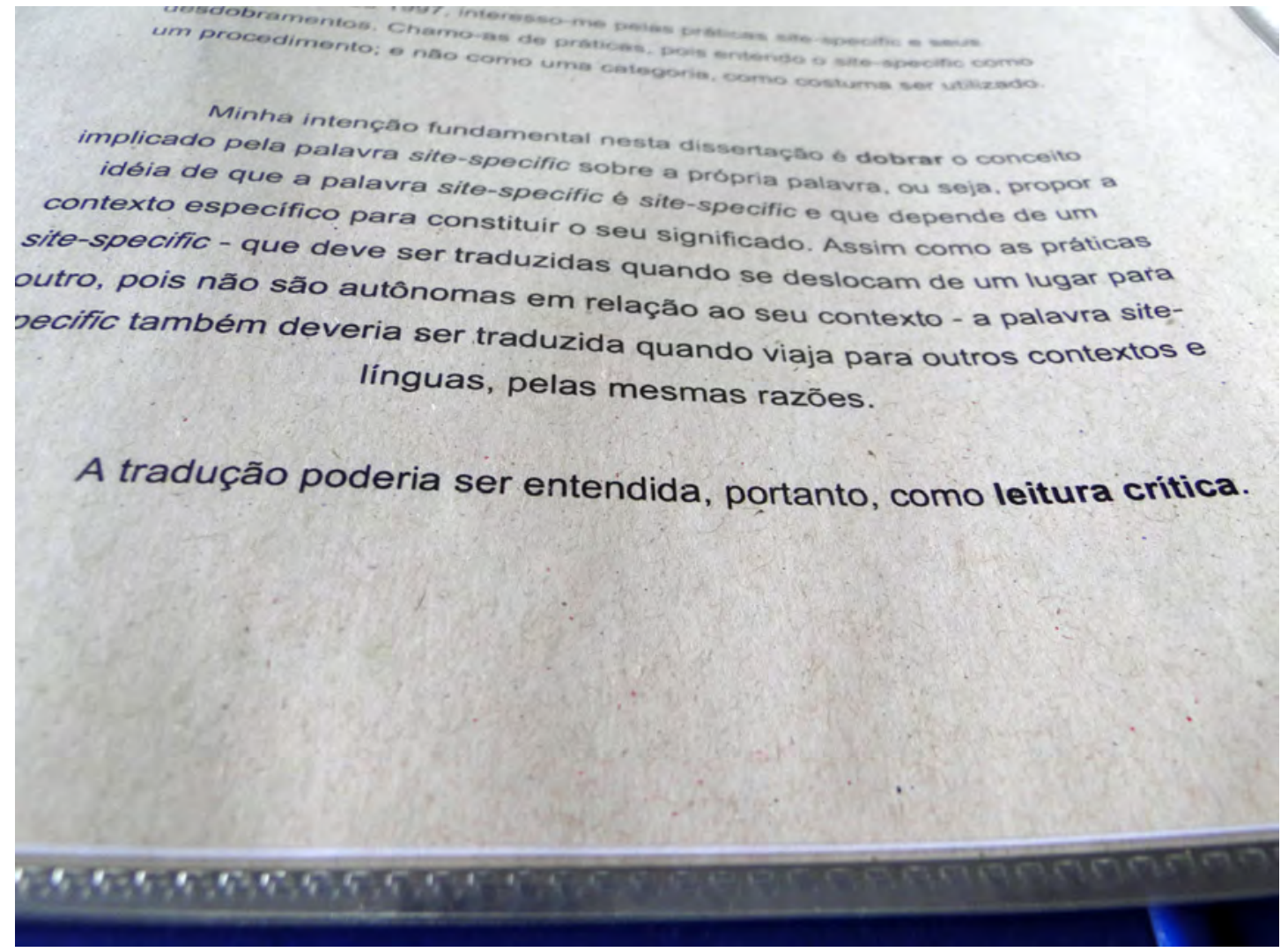

Fotografia da pág.10 de minha dissertação de mestrado, Lugares Moles (2007). para o contexto brasileiro. A tradução, no entanto, não foi abordada como um ato que buscasse uma resolução para o impasse (a partir de um termo em português que fosse equivalente ao em inglês), mas sim enquanto uma leitura crítica. Para tanto, propus estratégias que ativavam a própria dissertação enquanto um campo específico passível de abrigar um pensamento tradutor sobre o tema, sem um tom conclusivo.

Uma tradução jamais é completa. Sua relação com o original é sempre fragmentária e eletiva. $\mathrm{O}$ ato de traduzir lida com renúncias e escolhas dos sentidos possíveis do original que se quer cultivar em uma outra língua, situação ou tempo. A tradução proposta em minha dissertação de mestrado enfatizava o aspecto localista da discussão sobre o site-specific, reivindicando a necessidade de reelaboração em caso de 
deslocamento do termo. Em uma revisão crítica, poderia dizer, assim como questionado na hipótese de Miwon Kwon, que minha tradução está excessivamente calcada na concepção de site, rebaixando outras riquezas do conceito que hoje reivindicam visibilidade.

No entanto, a questão da especificidade mi problema, é abordado a partir das discussões gerar Umas delas - também abordada em minha pesquisa de mestrado, mas não explorada suficientemente - é o entendimento do siteye "descolamento do site" trazidas por Miwon Kw onceito e prática do site-specific deslocado da -specific como uma metodologia artística, distinta do seu uso mais corrente enquanto categoria (assim como escultura, desenho, fotografia, instalação, etc.).

\section{O site-specific como um método}

As cinco etapas elaboradas por mim que definem o site-specific enquanto um método de construção de uma obra são: escolba do site, escuta e mapeamento, identificação de um problema, construção da obra

\section{Conforme dito anteriormente, o crité} ória que apresento neste capitulo é - dividida entre projeto e realização - e por último, fissuras. A etapa que traça uma linha divisória mais explícita em relação a outras práticas artísticas é escuta e mapeamento. É ela que garante uma qualidade investigativa e analítica ${ }^{33}$ da relação que o artista estabelece com um determinado lugar, possibilitando que se desprograme o embate criativo (muitas vezes baseado em clichês) do artista

Fotografia da pág.27 de minha dissertação de mestrado, Lugares Moles (2007).

33 O uso destes dois adjetivos baseia-se no texto de apresentação da revista virtual Art and Research (2007), no qual os editores discorrem sobre os seus possíveis leitores: "Art and Research se endereça às preocupações dos artistas contemporâneos, ou, para evocar Nietsche, aos artistas com inclinações analíticas e investigativas". Capturado em 30 nov. 2011. Online. Disponível em: <http://www.artandresearch.org.uk/v1n1/ v1n1 editorial.html> (tradução minha). 


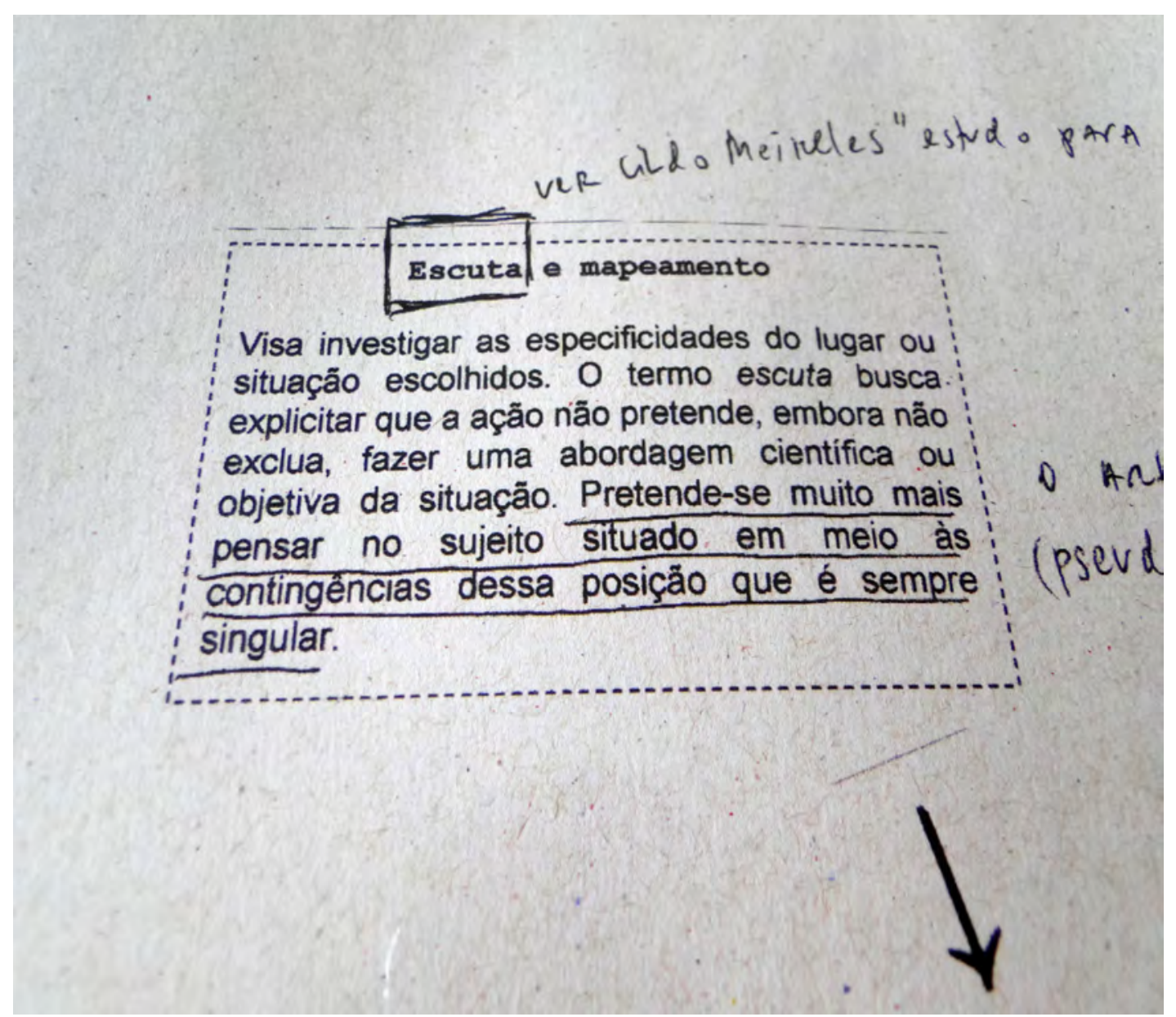

com um dado espaço e produzindo uma relação que se desdobra no tempo. A força das práticas site-specific está na investigação de uma localidade, desnaturalizando-a enquanto mero suporte para uma ação artística e expondo saliências e complexidades. Reside aí a possibilidade de produzir uma relação complexa de pertencimento entre obra e contexto (por embate ou adesão, mas nunca por indiferença), pulverizando a ideia de obra enquanto um sistema autônomo e autocentrado.

Tais considerações levam a uma compreensão do site specificity enquanto uma prática de investigação, reverberando assim de volta para a concepção de research-based art. Seria precipitado dizer que o termo research-based art é uma tradução (enquanto atualização) da expressão site-specific. No entanto, é possível afirmar que o termo research-based art traduz de maneira precisa um aspecto fundamental das práticas site-specific, que é a sua relação intensiva com a pesquisa e uma leitura vigorosa. Deve-se atentar para o fato de que esta possibilidade de tradução não considera mais

Fotografia da pág.29 de minha dissertação de mestrado, Lugares Moles (2007).

o deslocamento entre línguas e localidades, conforme realizado em minha pesquisa de mestrado, pois já tem como dado uma linguagem internacional e internacionalizante da arte contemporânea. Considerando o debate acima, o termo "pesquisa”, quando utilizado em meu texto, deve ser lido em alta voltagem. 


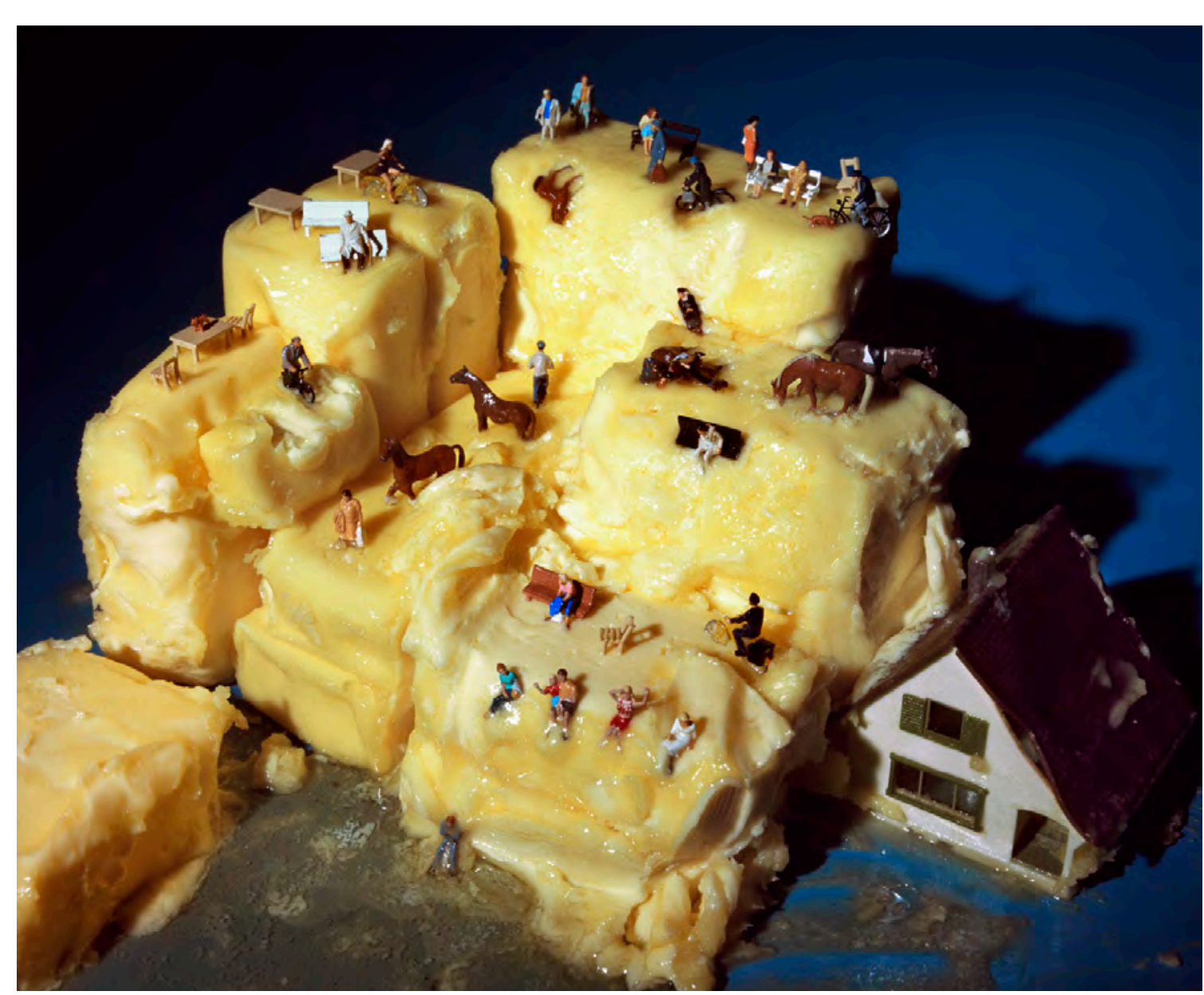

\section{Uma leitura que desmancha \\ o que lê}

A tese está dividida em sete capítulos, dedicados a diferentes hobras de minha trajetória enquanto artista e às leituras que as provocaram: Cildo Meireles, Leonilson, Felix Gonzales-Torres, João Cabral de Melo Neto, Ian Hamilton Finlay, Lina Bo Bardi e Hélio Oiticica, tratados nesta ordem. Todas as bobras foram pensadas para situações específicas. A convivência propiciada pela tese é inédita. Como toda aproximação feita por afinidade, realçam-se os aspectos comuns, o que por vezes difere das qualidades que possam ter sido enfatizadas em seus contextos de origem, em outras vizinhanças. Embora tenha dado uma atenção especial aos seus contextos originais, não se deve procurar nas descrições um significado intrínseco e último, pois a leitura que faço está defletida pela narrativa do agora. Neste sentido, no que a escrita atual modifica o que foi, o Lugares Moles texto se revela também como uma continuidade de cada um dos processos de pesquisa, (fotografia digital), 2007, Jorge Menna Barreto. afirmando a condição processual da reflexão sobre os projetos, sua distensão no tempo e disposição para revisões.

No primeiro capítulo, A tradução como leitura atenta, abordo a bobra Inserções Revista (2003), que partiu de um convite para intervir na Revista Número 3 e cujo mote 
era arte e palavra. A pesquisa preparatória para a intervenção envolveu uma leitura dos escritos de Cildo Meireles da década de 1970, a qual permitiu identificar uma suposta fratura entre a sua produção mais recente e a daquela época. Propus assim uma resposta que discute questões de autoria, emancipação do público e leitura. De uma geração posterior à de Cildo, a chamada Geração 80, Leonilson é objeto de leitura no segundo capítulo, intitulado $A$ influência pela negatividade. O contexto é o de uma exposição na Galeria Vermelho ${ }^{34}$, em 2003, por ocasião do décimo ano do seu falecimento. O intuito da curadoria era criar uma espécie de cartografia da influência da obra de Leonilson, identificando de que maneira o seu legado é lido e atualizado na obra de artistas mais jovens. A hobra que propus, Área Semicrítica de Contaminação, respondeu à situação por um viés negativo, questionando a própria noção de influência.

No terceiro capítulo, $A$ tradução como participação crítica, articulo concepções de tradução e participação, baseando-me na obra de Felix Gonzales-Torres, para a qual propus uma hobra-resposta chamada Felix. A ocasião foi a $7^{a}$ Bienal de Havana, em 2000, cuja proposta curatorial centrava-se em trabalhos que pensavam relações de proximidade entre artista, obra e público. Minha abordagem da obra de Felix Gonzales-Torres sugeria portanto um quarto eixo de acercamento: aquele entre artista e artista. A ideia de tradução ganha uma inclinação especial ao pensá-la como uma Aproximação entre Temperaturas, título do quarto capítulo. Partindo de uma pesquisa sobre João Cabral de Melo Neto, identifico uma ambiência da qual me aproximo com um grupo de hobras-resposta que foram apresentadas na $7^{\text {a }}$ Bienal do Mercosul (2009).

Em O leitor situado e a instabilidade do original, título do quinto capítulo, analiso a hobra Concreto (2010), que consiste na proposição de transcriação de uma obra do artista-poeta escocês Ian Hamilton Finlay. A discussão sobre a tradução interlinguística surge explicitamente aqui, já que o trabalho de Finlay contém um inscrito em inglês que é vertido por mim para o português. Contemporânea de Finlay, Lina Bo Bardi integra a análise

34 A Galeria Vermelho é uma galeria de arte contemporânea em São Paulo em atividade desde o início dos anos 2000. Ver: www.galeriavermelho.com.br. 
a análise da hobra Concreto e também é tema do sexto capítulo: Ambientação não-conciliatória. Inspirada na arquiteta, a hobra que proponho para o $32^{\circ}$ Panorama da Arte Brasileira (2011) busca reimaginar a relação de permeabilidade arquitetônica do MAM-SP - projetado por Bo Bardi - com a marquise do Parque Ibirapuer $\mathrm{a}^{35}$, onde está situado o museu. O último capítulo, Tradução digestiva, analisa a hobra Metabólide, concebida a partir da leitura do livro Aspiro ao Grande Labirinto de Hélio Oiticica e apresentada na mostra Transfronteiras no Memorial da América Latina em São Paulo (2010).

A ideia de desmanche daquilo que leio não caracteriza apenas uma busca por abrir, dilatar e expandir as obras originais a partir de uma nova obra, mas igualmente identificar o quanto elas mesmas fazem esse movimento em relação a outras origens, com as quais se relacionam de maneira forte. É o caso, por exemplo, de Cildo Meireles, que nos seus escritos sobre Inserções, deixa claro que a obra pretende pensar criticamente, aprofundar e avançar a ideia do readymade duchampiana. Outro exemplo é a relação de influência que João Cabral de Melo Neto teve a partir do arquiteto Le Corbusier, a qual em dado momento ganhou um viés de contrariedade. Dessa maneira, as concepções de origem e originalidade trabalhadas aqui se ligam ao que Susana Lages escreve sobre Ladrões de Palavras de M. Scheinder:

O conceito de originalidade é diferentemente entendido ao longo da história. A ideia renascentista de originalidade difere, por exemplo, da ideia moderna, no sentido de que, para a sensibilidade da Renascença, o novo deveria guardar, necessária e paradoxalmente, uma relação com o antigo; enquanto, para a modernidade, devem ser apagados os rastros do passado na obra presente para que ela apareça absolutamente nova, sem liames com o passado, a tradição, como se fosse autogerada (Lages 2002: 55).

35 O Parque Ibirapuera é o parque urbano mais importante da cidade de São Paulo, cujo projeto arquitetônico é de Oscar Niemeyer e o projeto paisagístico, de Roberto Burle Marx. 


\section{Origem e resposta}

Toda tradução inevitavelmente remete a uma origem. É importante, no entanto, desestimular o entendimento de origem enquanto fonte ou gênese para ressignificá-la enquanto salto e recorte. É esta a tarefa de Walter Benjamin ao aproximar o significado literal da palavra origem em alemão (Ursprung) da ideia de salto que lhe constitui (Sprung). Neste sentido, conforme analisa Jeanne-Marie Gagnebin, “Ursprung designa, portanto, a origem como salto (Sprung) para fora da sucessão cronológica niveladora à qual uma certa forma de explicação histórica nos acostumou. Pelo seu surgir, a origem quebra a linha do tempo, opera cortes no discurso ronronante e nivelador da historiografia tradicional” (Gagnebin 2009: 10). Esse posicionamento revela uma qualidade política do entendimento de história e origem contida no pensamento de Walter Benjamin, ao qual esta tese adere, que "ressalta que a narração da historiografia dominante, sob sua aparente universalidade, remete à dominação de uma classe e às suas estratégias discursivas. Esta narração por demais coerente deve ser interrompida, desmontada, recortada e entrecortada” (Gagnebin 2009: 17).

A imagem do salto, como descolamento do contínuo histórico e projeção para o presente, requer uma atualização, pois não se trata de apenas resgatar um objeto autônomo e fechado, mas de uma elaboração - ou tradução - que redesenhe este salto até o presente. De acordo com Julio Plaza, na esteira de Walter Benjamin, "trata-se de uma captura da história como reinvenção da história face a um projeto do presente" (Plaza 1984: 5). Assim, o processo de reinvenção ocorre a partir de uma leitura que inquieta a "cronologia tranquila da história oficial” (Gagnebin 2009: 10) e propõe a emergência da diferença: “o Ursprung não é simples restauração do idêntico esquecido, mas igualmente, e de maneira inseparável, emergência do diferente” (Gagnebin 2009: 18).

O fenômeno da "emergência do diferente" pode ser associado ao "espaço de aparição” da alteridade, tal como descrito por Rosalyn Deutsche, analisando as teorias de 
Hannah Arendt e Claude Lefort (Deutsche 2009: 176). Para Deutsche, a aparição da alteridade - fenômeno ligado à visão - tem implicações políticas e sociais, atuando na formação da esfera pública e da democracia. Ao fazer emergir e tornar visível a diferença, questionam-se as certezas sobre as fundações da vida social, possibilitando o debate e a manifestação de uma alteridade. No entanto, mais importante do que apenas tornar visível está a questão de “como respondemos à aparição" (Deutsche 2009: 176). A autora desenvolve essa análise a partir da obra Projeção Hiroshima (1999) de Krystof Wodiczko, na qual o artista trabalha junto às vítimas do bombardeio atômico daquela cidade e elabora meios de representação desse outro, mas que ao mesmo tempo consideram a própria "falência - a inadequação - da representação” (Deutsche 2009: 180). Adensando - a partir da análise da obra de Wodiczko - a concepção de resposta, a autora desenvolve a ideia de "respons(h)abilidade" ${ }^{36}$, ou da habilidade de resposta, tal como a elabora Emanuel Lévinas ao reivindicar a "não-indiferença”. De acordo com Deutsche: "A 'não-indiferença' designa a habilidade de responder ao outro, uma 'responsa(h)abilidade'[...]”(2009: 178), que desempenha um papel importante no "aprofundamento e expansão da democracia" (Deutsche 2009: 176). Deve-se considerar que a noção de outro, tal como a utilizo na minha pesquisa, difere daquela do suprimido, vitimado ou soterrado pela história. Os autores a partir dos quais elaboro respostas têm, ou tiveram, grande visibilidade pública. Trata-se assim de recuperar traços desse outro hipervisível que por ventura possam ter ficado suprimidos ou soterrados. Nesse sentido, lido com a ideia do "outro dentro do outro”, não a partir das suas características enquanto indivíduo unitário, mas da diferença que o habita e destoa da maneira como é representado usualmente. O que se busca são impressões que não estão em sua aparência, mas que podem emergir no ato tradutório. A concepção de origem, enquanto salto diferencial para fora do contínuo histórico, assim como a de resposta, enquanto ato de responsabilidade ética e política diante da emergência da diferença, integram o alicerce dos exercícios de leitoria.

36 Termo cunhado por mim para traduzir o jogo de palavras que a autora faz em inglês a partir de "responsability: response ability”. DEUTSCHE, Rosalyn. A arte de ser testemunha na esfera pública dos tempos de guerra. In: Revista Concinnitas. n.15. Pós-Graduação UERJ. 2009, p. 174-183 (trad. Jorge Menna Barreto). 


\section{Exercícios de leitoria}

As hobras escolhidas, enfrasadas ${ }^{37}$ por ocasião da tese, partem da leitura da produção de um grupo de autores, para os quais elaboro respostas críticas enquanto autor. $\mathrm{O}$ jogo faz parte do que denomino Exercícios de leitoria, hipótese central e título do texto. A expressão leitoria - soma das palavras leitura e autoria - não é dicionarizada. A partir de um desvio em seus sentidos, as duas palavras chocam-se e fundem-se, misturando trajetórias, conteúdos e produzindo um novo feixe de forças. O termo que resulta foi inventado por ocasião da tese e define-se enquanto um exercício ${ }^{38}$. Não é portanto uma atribuição identitária de um sujeito. Leitoria é uma prática. Não compete assim com as categorias históricas e conceituais de autor ou leitor, que caracterizam um ser/identidade. Quali fica sim um fazer, que oscila entre as tarefas do leitor e do autor. No que explora as possibilidades de investigação entre a leitura e a autoria, uma outra imagem possível de ser construída é a de uma de expansão do espaço entre elas, não como distanciamento, mas como ganho de superfície, de oxigenação e de multiplicação das possíveis graduações ou tonalidades entre as duas. A imagem se aproximaria portanto da seguinte espacialização:

\section{Leitura}

Autoria

O exercício começa na investigação da obra (ou aspectos dela) de um outro autor, chamada aqui de obra-original, a partir da qual construo uma obra-resposta. No primeiro caso apresentado, a obra-original é Inserções em Circuitos Ideológicos (1970) de Cildo Meireles; a obra-resposta, Inserções Revista (2003). O exercício de leitoria pode agregar,

37 Verbo forjado por João Cabral de Melo Neto no poema Rio sem discurso (1966). Online. Disponível em: $<$ http://www.eca.usp.br/comueduc/antigos/poesia/poesia17.htm>

38 A expressão "exercícios críticos", para referir-se às obras apresentadas, foi sugerida por Ricardo Basbaum na banca de qualificação para esta tese em 2010. De maneira oportuna, o termo "exercício" também convida à lembrança da expressão "exercício experimental da liberdade" de Mário Pedrosa. Ver PEDROSA, Mário. Por dentro e por fora das Bienais. In: AMARAL, Aracy (org.). Mário Pedrosa - Mundo, Homem, Arte em crise. Coleção Debates. São Paulo: Editora Perspectiva, 1975. 
no entanto, novos tensores. É o caso da leitura que faço hoje, a qual, a partir de um novo engate, intercepta e estira o vínculo entre a obra-original e a obra-resposta:

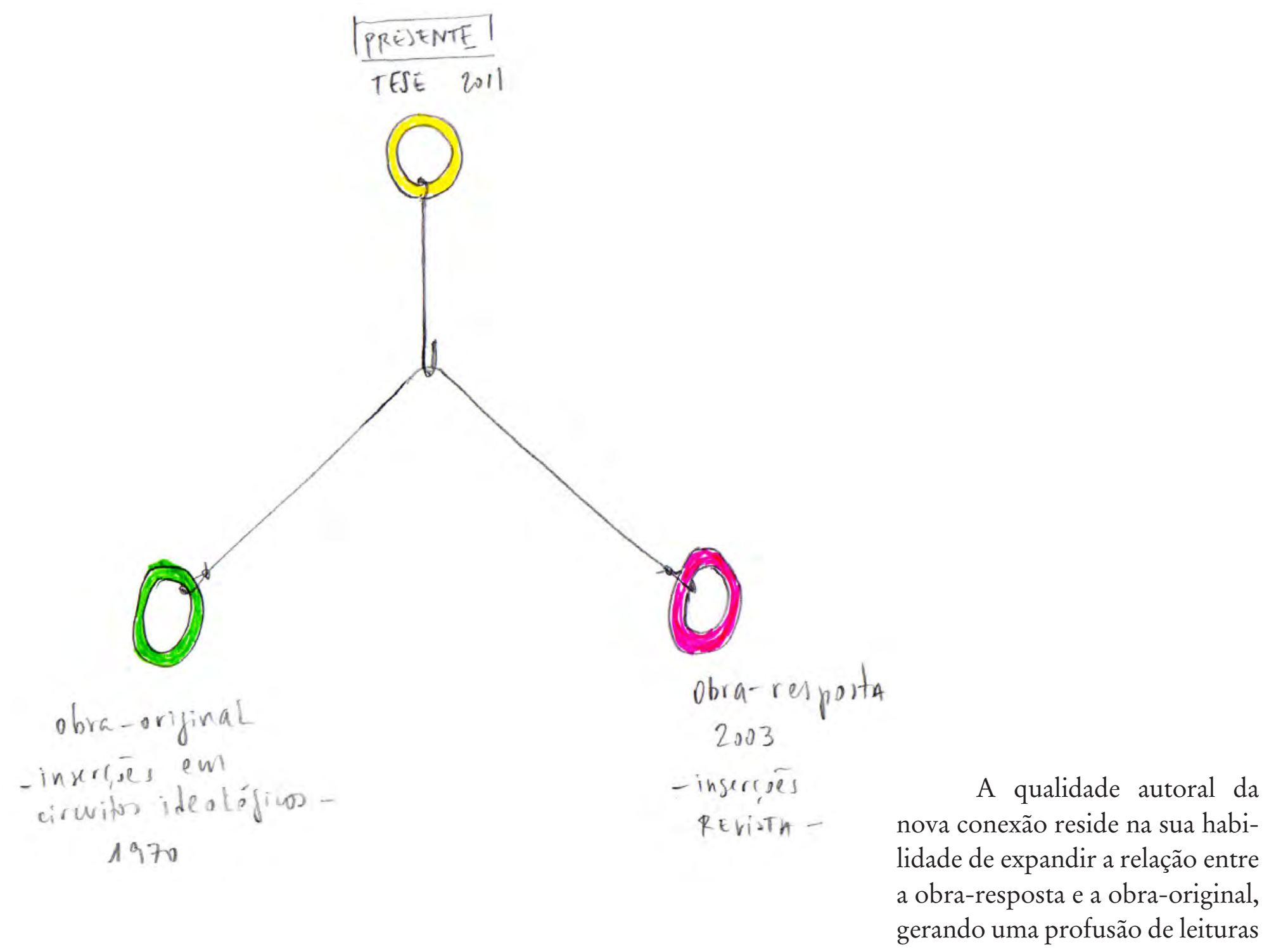


de outras obras e autores. No caso do capítulo 1, uma espacialização possível seria:

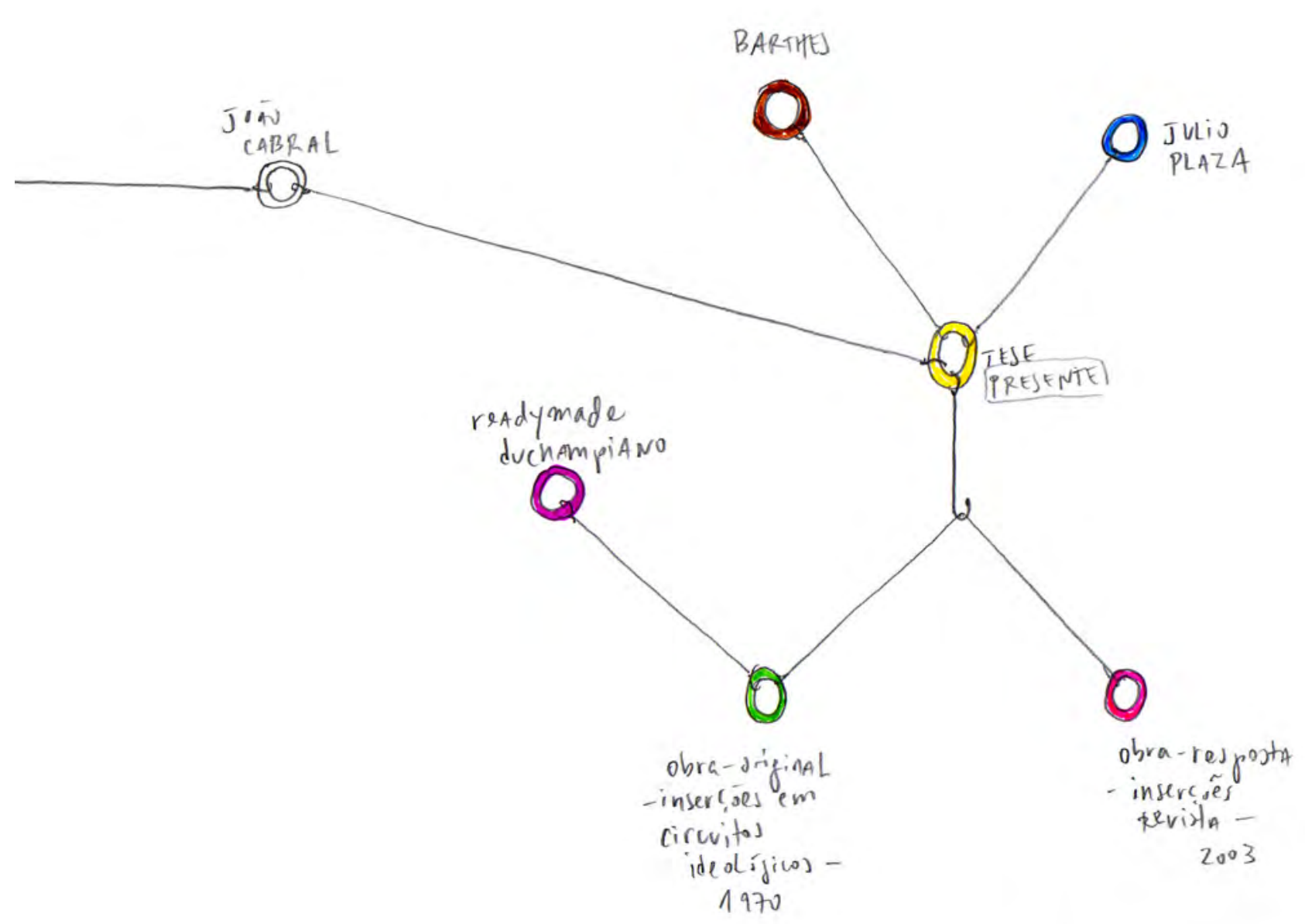

(O anel é uma imagem sugestiva para pensar as diferentes instâncias apresentadas nos desenhos. Como estrutura, o anel é pura exterioridade. Seu lado interno é oco, podendo ser permeado e atravessado por diferentes fluxos e linhas. A borda é o que lhe dá forma e possibilita as relações de entrelaçamento. Seu valor está na sua vocação acoplativa)

A última instância abordada pelos exercícios de leitoria é a do leitor. É onde entra a consciência da própria tese enquanto texto, que se relaciona com a sua recepção a partir do ato da leitura. Dito de outra maneira, o conteúdo da tese, a discussão sobre as concepções de leitura e autoria, toma a forma de um texto para ser lido. O leitor - destino final dos anéis e seus entrelaçamentos - tem a oportunidade assim de refletir sobre a própria maneira como se relaciona com o conteúdo que está lendo. Ao explicitar o jogo, pretendo que o material não seja apenas lido, mas lido fortemente. A prática da leitoria é o que a tese busca fortalecer, ou até mesmo formar. 
atesta $u$ ucovchumamento d a, cabe à solidez substituir , de altitude sobrepõe-se a c , fundo/ das coisas desce") nte, na escavação do real. s duas últimas quadras i1 o à proposta de "A Paul V:
um tipo de silêncio que 1 


\section{A TRADUÇÃO COMO LEITURA ATENTA: CILDO MEIRELES}

Inserções Revista

Intervenção na Revista Número Três, São Paulo (2004)

Semelhante à hobra Área Semicrítica de Contaminação, que será analisada no capítulo seguinte, a intervenção Inserções Revista também integrou minha dissertação de mestrado ${ }^{39}$, embora tenha sido chamada então de Revista Número Três. A revisão do nome, propiciada pela tese, já anuncia que não estamos mais diante do mesmo objeto, ou melhor, de que a hobra pulsa e é passível de ser reinterpretada, reposicionada e atualizada. O que retorna jamais o faz na mesma forma. $\mathrm{O}$ título revisto igualmente nos fala da qualidade do olhar que se apresenta, disposto a modificar o que passou e desmanchar o que parecia estável. A palavra "revista" se mantém do antigo para o atual, agregando novas possibilidades de leitura e alinhando a hobra à pulsão revisionária ${ }^{40} \mathrm{da}$ tese.

O contexto para o qual foi idealizada é o da revista de crítica de arte paulistana Número ${ }^{41}$, então em sua terceira edição. O foco da Número Três, lançada no início de 2004, era investigar as relações entre arte e palavra em suas múltiplas possibilidades: o texto crítico, o de artista, o texto curatorial, o texto como obra, na obra, e até mesmo a

39 Ver MENNA BARRETO, Jorge. Lugares Moles (229pgs.). Dissertação de Mestrado em Artes Plásticas/ Poéticas Visuais, ECA-USP, São Paulo, 2007.

40 Ao traduzir Six revisionary reasons para o português, Arthur Nestrovski opta por utilizar o neologismo revisionário, ao invés de revisionista, que seria a tradução literal. Ao realizar esse desvio criador, o tradutor aproxima-se da ideia de desleitura proposta pelo próprio autor do livro que traduz, Harold Bloom. Utilizo portanto a transcriação de Nestrovski, em acordo com sua leitura forte. BLOOM, Harold. A angústia de influência: uma teoria da poesia. Rio de Janeiro: Ed. Imago, 1991, p.43.

41 A revista Número é voltada ao debate sobre arte contemporânea e visa estimular a reflexão crítica sobre o panorama artístico nacional. Online. Disponível em: <http://www2.cultura.gov.br/programas_e_acoes/ cultura_e_pensamento/acervo/textos/index.php?p=25055\&more $=1 \& \mathrm{c}=1 \& \mathrm{pb}=1>$ 
relação do artista (e da arte) com a universidade. A convite dos editores, propus uma intervenção para ser realizada em suas páginas.

Construindo repertório para o meu projeto, realizei uma pesquisa sobre obras relacionadas ao tema da revista, especialmente as que pensavam os meios de circulação enquanto suporte. Sob esta mirada, revisitei uma obra emblemática da década de 1970 que acabou norteando meu projeto: Inserções em Circuitos Ideológicos, de Cildo Meireles. O projeto envolvia uma série de intervenções (ou inserções) em certos mecanismos de circulação definidos pelo artista como circuitos ${ }^{42}$. Consistia em duas ações: Coca-cola, na qual o artista imprimia textos subversivos em garrafas de Coca-Cola e as devolvia à circulação; e Cédula, na qual carimbava textos em notas de dinheiro, também devolvidas à circulação.

A investigação da obra de Cildo possibilitou um adensamento da reflexão sobre o tema arte e palavra. $\mathrm{O}$ texto desempenha múltiplas funções em Inserções, não somente como conteúdo, mas também a partir de artigos redigidos e publicados pelo artista sobre as ações. Interessante notar que Cildo atribui ao próprio texto a origem dos projetos Cédula e Coca-cola:

O trabalho começou com um texto que escrevi em abril de 1970 e que coloca esta situação:

1. Na sociedade existem certos mecanismos de circulação (circuitos).

2. Estes circuitos incorporam claramente a ideologia do produtor, mas ao mesmo tempo são passivos quando recebem inserções nos seus circuitos.

3. Isto ocorre sempre que alguém começa um circuito (Meireles 1999: 110).

A escrítica do artista vai além, tornando-se um local privilegiado para uma reflexão

42 Além de mercadorias e notas de dinheiro, a reflexão sobre circuitos também envolvia jornais e revistas. 
sobre a obra, contextualizando-a na trama social da época e na história da arte. Em seu texto, analisa e afirma que Inserções considerava as seguintes questões:

1. a dolorosa realidade político-social-econômica brasileira, conseqüência em boa parte do

2. American way of politics and culture e sua ideologia (filosofia) expansionista, intervencionista, hegemônica, centralizadora, sem perder de vista os 3. aspectos formais da linguagem, ou seja, do ponto de vista da história da arte, a necessidade de produzir um objeto que se pensasse produtivamente (criticamente, avançando e aprofundando), entre outras coisas, um dos mais fundamentais e fascinantes de seus projetos: os readymades de Marcel Duchamp. As Inserções em Circuitos Ideológicos explicitavam o primeiro e o segundo itens acima, e sobretudo enfatizavam as questões de linguagem contidas no terceiro (Meireles 1999: 108).

Se os textos reunidos evidenciam a relação de Cildo com a palavra enquanto escritor - apontando para a origem, conteúdo e espaço de reflexão de Inserções -, seu olhar para Marcel Duchamp nos revela o artista-leitor. Ao qualificar a sua relação com os readymades, a partir de expressões como pensar criticamente, avançar e aprofundar, Cildo expõe a direção e a qualidade da sua leitura, tão forte a ponto de gerar uma resposta crítica que desacomoda o seu objeto de análise. De acordo com Herkenhoff: "Inserções em Circuitos Ideológicos trabalha um objeto que contenha o problema colocado pelo readymade como operação com o anódino. Reverte-se a operação duchampiana de colocar o objeto industrial no universo da arte. Introduz-se a coisa artística na memória produtiva, heroico embate do indivíduo com a formidável escala industrial. As premissas são a existência de certos mecanismos de circulação na sociedade, inclusive a ideologia do capitalismo" (Herkenhoff 1999: 63). 
A leitura crítica da tradição, que busca entremeios e brechas para novas interpretações - ou mesmo uma reversão, conforme afirma Herkenhoff, poderia ser aproximada da ideia de tradução ${ }^{43}$, reverberando nos escritos do artista-tradutor Julio Plaza: "a tradução, para nós, se apresenta como 'a forma mais atenta de ler' a história...” (Plaza 1984: 36). De acordo com Plaza, a noção de história aberta a novas interpretações - característica da maneira como o artista-tradutor a percebe, como potência - é apoiada em Marcel Duchamp e Mikhail Bakhtine:

Para Marcel Duchamp, uma obra se completa com o público. E, para Bakhtine, o "inacabamento de princípio" e "abertura dialógica" são sinônimos. A história inacabada (assim como as obras de arte) é uma espécie de obra em perspectiva, aquela que avança, através de sua leitura, para o futuro. A história "acabada" é a história morta, aquela que nada mais diz. História então, pressupõe leitura. É pela leitura que damos sentido e reanimamos o passado (Plaza 1984: 3).

Cabe à leitura atenta portanto a tarefa criadora de produzir novos sentidos, trabalhando junto com o autor, "tanto no sentido cooperativo quanto no sentido subversivo" ${ }^{44}$. A isso chamo de tradução.

\subsection{A intervenção}

43 A ideia da tradução como leitura crítica foi inspirada no artigo Estranbamento da Tradução na Criação, de Edilamar Galvão: "Podemos pensar aqui que a tradução (como a leitura e a crítica) é o procedimento capaz de retirar a vanguarda literária do mundo da contemplação para tratá-la como 'objeto lingüístico vivo', pronto 'para a ação',...”. As aspas referem-se a um texto de Haroldo de Campos, retirado por Galvão do livro Traduzir e Trovar (1968). GALVÃO, Edilamar In: NUNES, Sandra Regina Chaves (org.). Estranhas Travessias. Osasco, SP: Ed. EDIFIEO, 2004, p. 59

44 CHAMBERLAIN, L. Apud. cit. LAGES, Susana, 2002, p.85. 


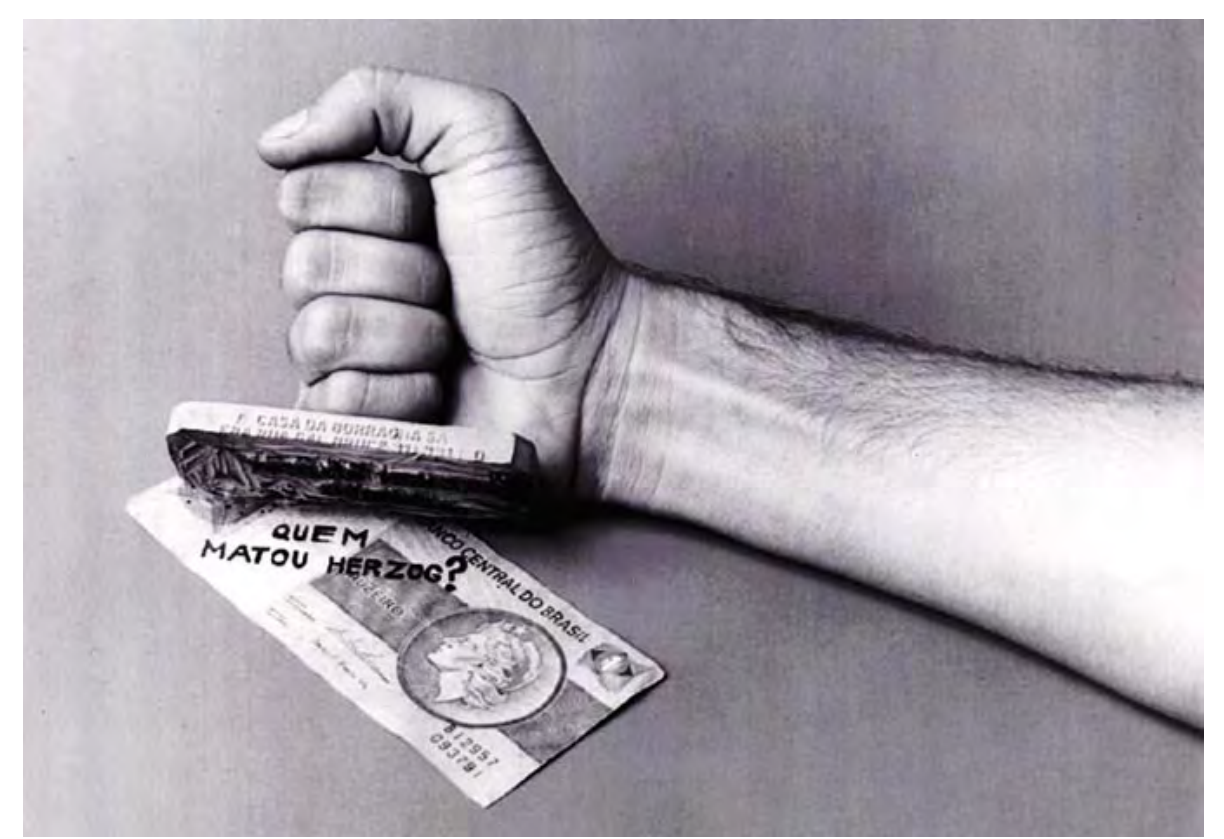

Inserções em Circuitos Ideológicos, 1970, Cildo Meireles.

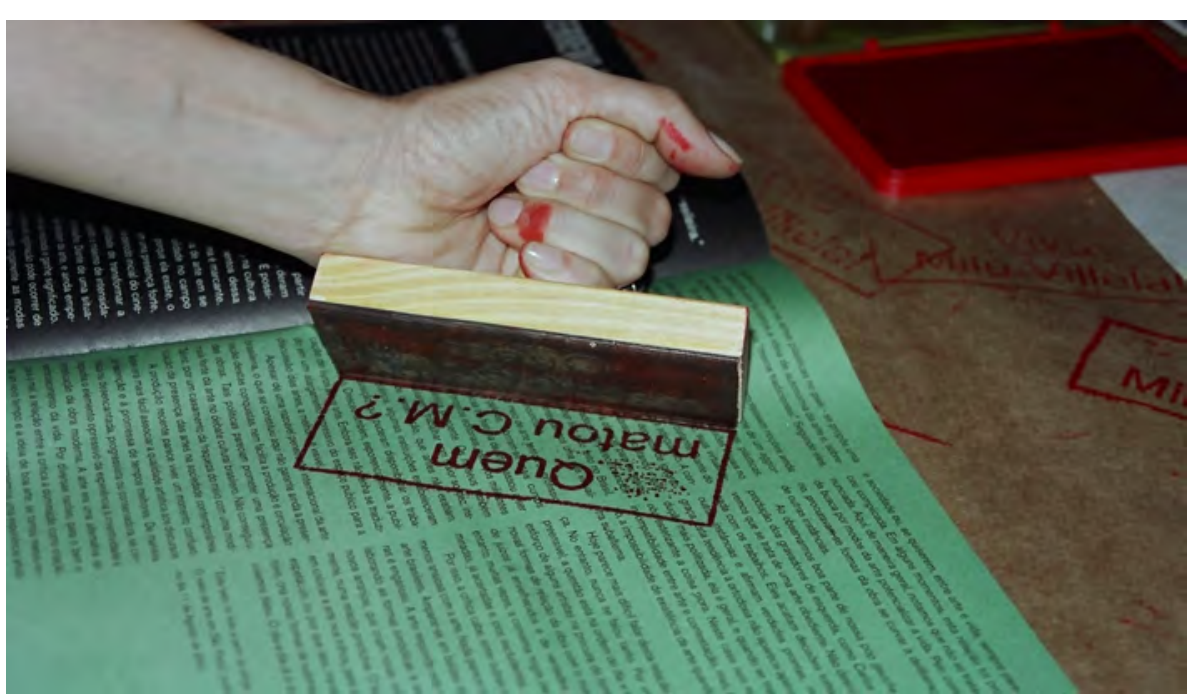

Inserções Revista, 2004, Jorge Menna Barreto.
A intervenção na revista Número se desdobrou em três momentos: o primeiro consistia na confecção de dois carimbos que seriam usados nas revistas já impressas antes de serem distribuídas: Quem matou C.M.? e Viva Milú Villela!; o segundo, no transplante para as páginas da $R e-$ vista Número de um artigo publicitário do MAM-SP, ilustrado por Milú Villela e originalmente publicado na revista Bravo!; e o terceiro, no convite aos autores dos artigos da revista a incluírem notas de apresentação e endereços de email ao final dos seus textos, abrindo a possibilidade de diálogo com o público leitor.

Quem matou C.M.? propunha uma re versão da pergunta Quem matou Herzog? (da série do Projeto Cédula, 1970). Pretendia-se realizar uma operação de dobra do autor da obra sobre ele mesmo, reescrita 34 anos depois. $\mathrm{O}$ sujeito-propositor das Inserções na década de 1970, que se ocultava sob as iniciais C.M., tornou-se o objeto da mesma indagação ${ }^{45}$.

45 O carimbo de Cildo Quem matou Herzog? fazia parte de uma intensa onda de manifestações de protesto em relação à morte do jornalista e diretor da TV Cultura, Wladimir Herzog, assassinado sob tortura nas dependências do DOI-CODI, em São Paulo, durante o regime da ditadura militar. Esta onda "trouxe uma comoção social que foi capaz de transformar tanta dor em luta pela Anistia. O Sindicato dos Jornalistas de São Paulo contestou a versão oficial de que Herzog teria se suicidado, o que desencadeou um movimento de protesto com repercussão internacional”. Capturado em 16 jan. 2007. Online. Disponível em: <http://www.desaparecidospoliticos.org.br/anistia/20anos.html> 


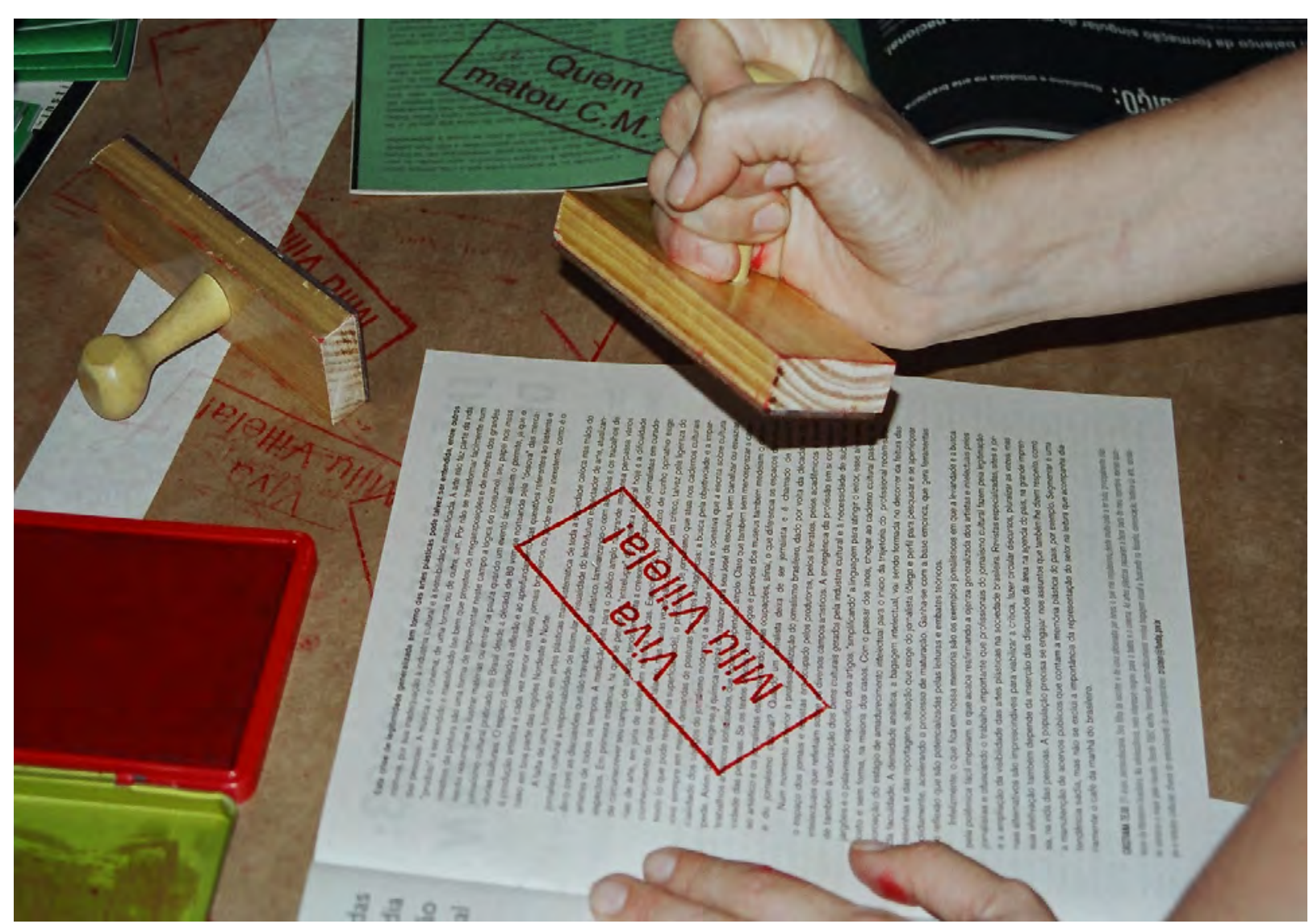

O outro carimbo celebrava Milú Villela, figura influente no meio das artes brasileiro e também no setor financeiro. Villela é presidente do Museu de Arte Moderna de São Paulo e do Itaú Cultural, além de sócia majoritária de um dos bancos com maior lucro no Brasil, o Itaú. As revistas foram carimbadas uma a uma e alternadamente. Ou seja, algumas com C.M e outras com Milú. Cada exemplar recebeu entre duas e três marcas em páginas aleatórias.

$\mathrm{O}$ artigo publicitário transplantado da revista Bravo! para a Número revelava o logotipo do MAM com o símbolo da Volkswagen sobreposto à letra a, aproximação que se supõe ter sido concebida pela própria Milú, já que o artigo foi ilustrado pela mesma ${ }^{46}$. No anúncio também encontramos o agradecimento de

Inserções Revista, 2004, Jorge Menna Barreto.

Milú Villela escrito à mão. No final da página, “A Volkswagen investe R\$ 27 milhões nas mais variadas manifestações culturais do Brasil: cinema, teatro, literatura, artes plásticas e música”. Em negrito, a declaração: "Investir em cultura. Não é favor, é nossa obrigação" (imagem a seguir).

46 Informação contida em letras minúsculas no próprio anúncio, ao lado de imagem, onde se lê: "Ilustrado por Milú Villela”. 

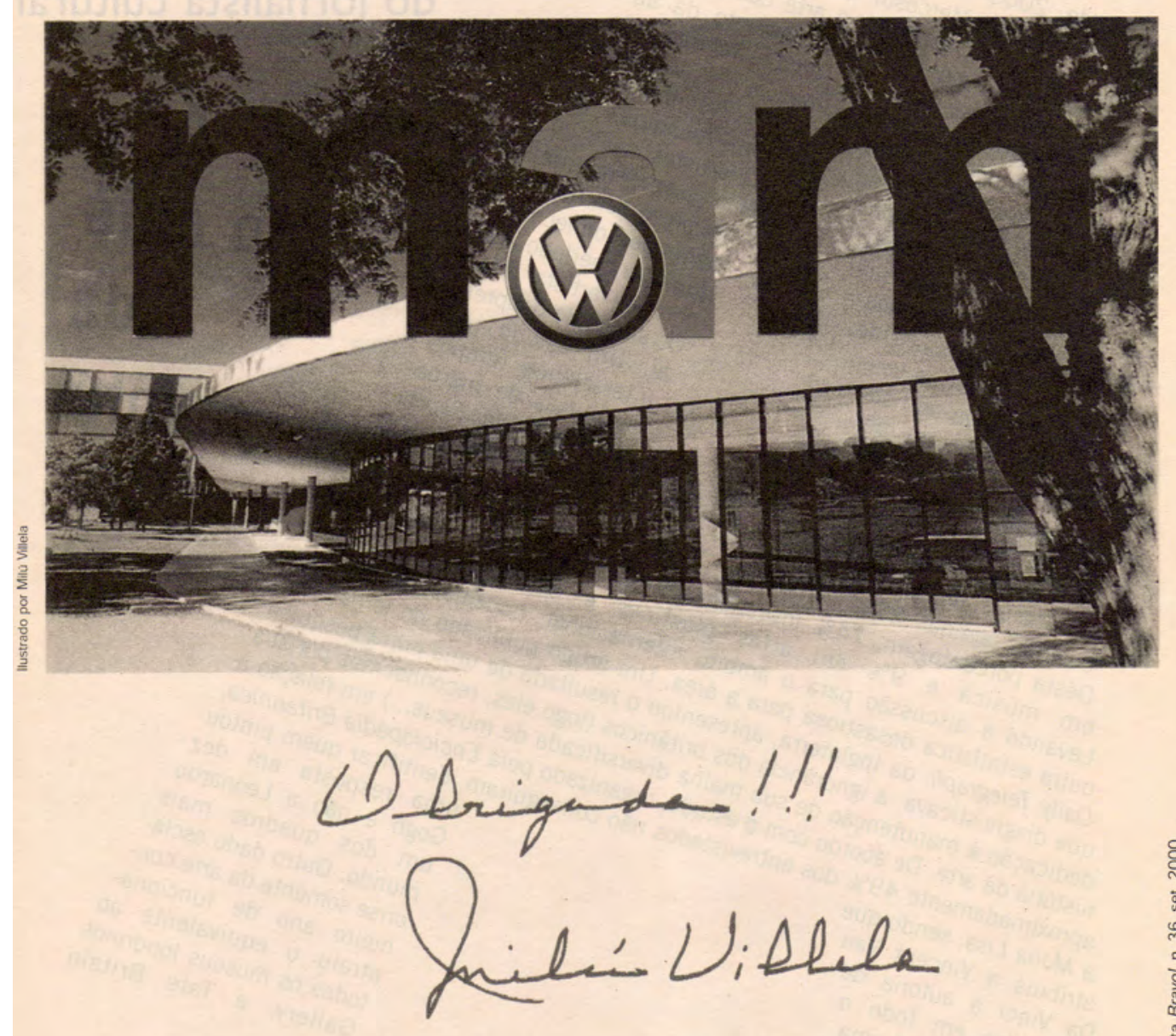
O terceiro momento da intervenção consistia, conforme já dito, no convite aos autores dos artigos da revista a incluírem notas de apresentação e endereços de email ao final dos seus textos. Sugeria-se assim a abertura de um espaço de resposta para o leitor da revista. O texto de apresentação de cada autor ficou sob inteira responsabilidade dos mesmos, como um exercício de autorrepresentação. Assim, variavam em tom e estilo. Além disso, a publicação dos seus endereços de email abria a revista para uma outra possibilidade de relação com a palavra, pensando-a não somente a partir do texto que publica, mas de uma resposta que poderá surgir a partir da sua recepção em uma temporalidade distinta.

\subsection{Cildo e C.M.}

C.M. é a forma como Cildo Meireles assinava muitas das suas ações em Inserções. Poderíamos atribuir algumas motivações a esta estratégia de um relativo ocultamento do autor. A primeira delas seria buscar proteção e anonimato pelo tipo de crítica social e política durante o período de ditadura militar e censura rígida no Brasil. Outra motivação seria o rebaixamento da figura do autor e do artista no intuito de valorizar a figura do leitor, já que seus textos convidavam a tomar uma atitude participativa frente ao trabalho e à realidade social, política e econômica.

A noção de circuitos ideológicos está intimamente ligada à ideia de realidade, palavra constante nos textos que Cildo escrevia. Tal preocupação - frequente em alguns artistas da época - estava relacionada ao que denomino consciência contextual em minha dissertação de mestrado ${ }^{47}$. No caso de Cildo, é interessante notar que a concepção de consciência estava presente em seus escritos como sendo uma das funções da arte, oposta

47 Denominei “consciência contextual” um estado de agudeza de percepção do contexto presente em algumas obras de arte do final da década de 1960 e início de 1970, momento em que passa a se utilizar a palavra site-specific em arte, assunto da dissertação. Ver MENNA BARRETO, Jorge. Lugares Moles (229 pgs.). Dissertação de Mestrado em Artes Plásticas/Poéticas Visuais, ECA-USP, São Paulo, 2007. 
à ideia de anestesia, função da indústria ${ }^{48}$.

Foi na época em que planejava a intervenção na Revista Número que visitei a exposição Panorama da Arte Brasileira, 2003, realizada no MAM-SP, com curadoria do cubano Gerardo Mosquera e que incluía uma obra de Cildo Meireles. O artista participou da exposição com um trabalho da série Descalas, constituído por 15 exercícios de desarranjo formal da estrutura de uma escada. "Mas você ainda pode identificar a escada. Talvez, se Paul McCarthy fosse fazer o desarranjo, ele quebraria, cuspiria em cima, daria chutes e pontapés. O desarranjo da escada de Cildo é muito brasileiro: é clean - a estrutura permanece mesmo se é desarranjada", opina o curador sobre a obra de Cildo ${ }^{49}$.

A atuação mais descompromissada com o contexto (social ou mesmo do Museu) que Cildo apresentou na exposição lançou-me em uma reflexão sobre uma possível distinção entre Cildo Meireles e C.M.. Ponderei que a forma como o artista atuava na década de 1970, diretamente na realidade ${ }^{50}$, se revelava distante do exercício mais formal que apresentava no Panorama, por exemplo. Reconheci assim o que considerei uma cisão, ou uma intradução entre a produção mais recente do artista e seu legado da década de 1970. A decepção sentida pela percepção de tal fratura provocou um desejo de resposta que buscasse manter vivo um teor de consciência contextual apontado em ações passadas de Cildo Meireles. É como se a constatação de um suposto abandono da causa - por mais pontual que pudesse ter sido - também a liberasse de seu defensor, deixando um espaço vago para aquele que ainda aposta no ideal. Gera-se um movimento de responsabilização por algo que se julga importante ou ausente em muito da produção contemporânea, algo que se gostaria de ver atualizado. A resposta encontrada para a intervenção na Revista Número tinha uma dupla pretensão portanto: apontar e respons(b)abilitar.

48 MEIRELES, Cildo in Cildo Meireles. São Paulo: Ed. Cosac \& Naify, 1999.

49 Ver ALZUGARAY, Paula. Mosquera e José Resende discutem a Panorama. Capturado em 05 jan. 2012. Online. Disponível em: < http://p.php.uol.com.br/tropico/html/textos/1767,1.shl>

50 Assim como Artur Barrio, Hélio Oiticica, Antonio Manuel, Luiz Alphonsus, Thereza Simões, entre outros. 
A oscilação entre a admiração e o desencantamento na leitura da produção de um autor também tornou-se motivo de reflexão para o poeta João Cabral de Melo Neto, que foi fortemente influenciado pela obra do arquiteto Le Corbusier: "Na última época de sua vida, na minha opinião, Le Corbusier caprichou para negar todos esses valores que pregava anteriormente. Falo sobre ele e sobre isso no poema 'Fábula de um Arquiteto'. A ideia desse poema me veio ao visitar, na França, a capela Ronchamp, por ele construída. Essa capela me provocou uma tal irritação, que me senti obrigado a escrever esse poema, cuja segunda parte é uma descrição da antiarquitetura. Pelo menos em relação ao que o próprio Le Corbusier tinha me ensinado a considerar arquitetura e a partir do que escrevi minha poesia" ${ }^{51}$ :

\section{Fábula de um arquiteto}

A arquitetura como construir portas de abrir; ou como construir o aberto; construir, não como ilhar e prender, nem construir como fechar secretos; construir portas abertas, em portas; casas exclusivamente portas e teto.

$\mathrm{O}$ arquiteto: o que abre para o homem (tudo se sanearia desde casas abertas) portas por-onde, jamais portas-contra; por onde, livres: ar luz razão certa.

2.

Até que, tantos livres o amedrontando, renegou dar a viver no claro e aberto.

Onde vãos de abrir, ele foi amurando opacos de fechar; onde vidro, concreto; até refechar o homem: na capela útero, com confortos de matriz, outra vez feto. ${ }^{52}$

51 ATHAYDE, Felix de. Ideias Fixas de João Cabral de Melo Neto. Rio de Janeiro: Ed. Nova Fronteira, 1998, p.133.

52 Capturado em 04 jul. 2011. Online. Disponível em: <http://www.casadobruxo.com.br/poesia/j/joa- 
É interessante pensarmos a relação de João Cabral com Le Corbusier e na maneira como o poeta fica irritado ao perceber uma suposta traição do arquiteto aos preceitos que havia engenhado anteriormente. $\mathrm{Na}$ condição de leitor atento da arquitetura e trajetória Le Corbusiana, o poeta reivindica o direito de reclamar e responder a esta traição com um poema-resposta, permanecendo assim fiel à primeira fase do arquiteto. Opera portanto um descolamento entre o autor e a obra, criando um vínculo de permanência e sobrevida com o que julga ter sido negligenciado. Resiste a uma atualização daquele que admira, congelando-o no tempo e fixando-se ao momento de sua predileção.

As causas que levam um autor a fazer supostos desvios na sua forma de pensar e agir, muitas vezes desapontando o seu público, não são de interesse aqui. Mais do que entender as motivações, ou conferir-lhes legitimidade e veracidade, interessa-nos uma defesa do ato da leitura atenta e da emancipação do leitor. Tal preocupação é manifestada pelo próprio Cildo Meireles. Sua noção de fonômenos - mistura de fonema com fenômeno - caracteriza obras que podem ser realizadas a partir de instruções. É a ideia do trabalho “emancipado do seu autor", ou de "separar o trabalho de sua patologia individual", e da falsa ideia de que "apenas um artista com uma história pessoal verdadeiramente extraordinária pode produzir um trabalho pessoal, íntimo e válido de interesse" ${ }^{53}$.

As ideias de leitor atento, emancipação do leitor, valorização da sua figura e rebaixamento do autor presentes neste texto reverberam diretamente nas reflexões de Roland Barthes sobre autoria. Em seu artigo $A$ morte do autor ${ }^{54}$ (1968), Barthes rebaixa a figura do autor, enaltecendo a do leitor:

o texto é feito de escrituras múltiplas, oriundas de várias culturas e que

oc07.htm>

53 Todas as citações deste parágrafo referem-se a OBRIST, Hans Ulrich. Arte Agora: 5 entrevistas. São Paulo: Ed. Alameda, 2006, p. 67.

54 BARTHES, Roland. A morte do autor. Capturado em 05 jan. 2012. Online. Disponível em: <http:// www.eca.usp.br/ciencias.linguagem/L3BarthesAutor.pdf> 
entram umas com as outras em diálogo, em paródia, em contestação; mas há um lugar onde essa multiplicidade se reúne, e esse lugar não é o autor, como se disse até o presente, é o leitor: o leitor é o espaço mesmo onde se inscrevem, sem que nenhuma se perca, todas as citações de que é feita uma escritura; a unidade do texto não está em sua origem, mas no seu destino, $[\ldots]^{55}$

Além, a "patologia individual” descrita por Cildo rima com o "prestígio do indivíduo”, criticado por Roland Barthes, que situa a questão historicamente no mesmo texto:

o Autor é uma personagem moderna, produzida sem dúvida por nossa sociedade na medida em que, ao sair da Idade Média, com o empirismo inglês, o racionalismo francês e a fé pessoal da reforma, ela descobriu o prestígio do indivíduo ou, como se diz nobremente, da "pessoa humana”. Então é lógico que, em matéria de literatura, seja o positivismo, resumo e ponto de chegada da ideologia capitalista, que tenha concedido a maior importância à "pessoa" do autor. ${ }^{56}$

Matar o autor tem, portanto, implicações históricas, políticas, sociais e econômicas e transcende a questão literária ou artística. Tal discussão é capital em Inserções em Circuitos Ideológicos. No carimbo Quem matou Herzog?, indaga-se quem é o autor de uma ação, responsável pela morte do escritor. A resposta é sabida: Herzog foi suicidado pelo regime ditatorial vigente no Brasil da época. Punia-se assim uma voz dissonante e espalhava-se o medo da discordância. Todo regime autoritário é autoral, e não suporta leituras distintas daquelas que ele mesmo prescreve. Numa ditadura, quem deve morrer é o leitor, para que o autor impere e lucre. $\mathrm{Na}$ inserção de Cildo, o autor é duplamente atacado: rebaixa-se o autor/artista e coloca-se o autoritarismo na mira. Não por acaso, o palco são notas de dinheiro.

55 Ibid., p. 70

56 Ibid., p. 66. 
As questões propostas por este texto são, no entanto, datadas: o projeto Cédula é de 1970; A Morte do Autor, 1968. Desde lá, o Autor se fortaleceu e consolidou o seu vínculo com o capital dominante. Barthes sabia que o Autor não morreria, ou não teria terminado o seu artigo com o duplo sentido do verbo que emprega: "o nascimento do leitor deve pagar-se com a morte do Autor" ${ }^{37}$. Se alguém deve pagar por uma morte, esse alguém só pode ser um Autor. Inserções Revista opera portanto a partir de uma certa nostalgia, na tentativa de resgate de uma visão que um dia pareceu viável. Resta-lhe a ironia do segundo carimbo, celebrando a ilustradora do artigo publicitário enquanto cumpre as suas obrigações como Autora, preside importantes instituições da arte brasileiras e atua no setor financeiro, cultivando um dos maiores e mais obscenos lucros do país.

57 Ibid., p. 70 (grifo meu). 
Saisir: traduire. Et tout est traduction à tout niveau, en toute direction.

Le mal, c'est le rythme des autres.

On parle à des décapités

les décapités répondent en "ouolof»

\author{
HENRI MICHAUX
}




\section{A INFLUÊNCIA PELA NEGATIVIDADE: LEONILSON}

Área Semicrítica de Contaminação ${ }^{58}$

Exposição Vizinhos, Galeria Vermelho, São Paulo (2003)

Artistas e curadores estão envolvidos aqui em um empenho conjunto de rememoração, talvez afirmativa, da obra de Leonilson (1957-1993). Enfrentam assim os problemas característicos de uma revisita ao passado - que, embora recente, já se faz histórico. O contexto é uma exposição coletiva que ocorreu na Galeria Vermelho, em São Paulo, no ano de 2003, por ocasião do décimo aniversário de morte do artista. A mostra fazia parte de um conjunto de eventos na cidade em sua homenagem. No entanto, ao invés de realizar uma exposição de trabalhos do próprio artista para relembrá-lo, a intenção da curadoria foi criar um mapeamento possível da influência que Leonilson exerceu em artistas de gerações mais jovens que não o tivessem conhecido pessoalmente ${ }^{59}$.

Leonilson pertenceu ao que se chamou "Geração 80"60 no Brasil. A denominação

58 Área Semicrítica de Contaminação foi tema de um capítulo de minha dissertação de mestrado, onde discuti o site-specific. Interessava-me, no caso de A.S.C, discorrer sobre as relações de especificidade que a obra traçava com o contexto da exposição para a qual fora criada, pensando a moldura curatorial como um site. Na tese, embora trate-se da mesma obra, a intenção é enfatizar os aspectos de contágio e contaminação ali presentes, que me levam a relacioná-la aos assuntos centrais de tradução, apropriação e influência contidos no texto. Ver MENNA BARRETO, Jorge. Lugares Moles (229 pgs.). Dissertação de Mestrado em Artes Plásticas/Poéticas Visuais, ECA-USP, São Paulo, 2007.

59 Os curadores Cauê Alves, Paula Alzugaray e Juliana Monachesi selecionaram os seguintes artistas: Ana Teixeira, Claudio Matsuno, Eliane Testone, Fabio Morais, Fabio Tremonte, Graziela Kunsch, Jorge Menna Barreto, Leya Mira Brander, Martha Lacerda, Rafael Assef, Renato Dib e Veronica Cordeiro.

60 A expressão fazia parte do título de uma exposição no Parque Lage, Como vai você, Geração 80?, no Rio de Janeiro, 1984. Pretendia reunir um possível panorama dos artistas da época sob uma identidade geracional, conforme o nome indica. Como todo recorte, também é excludente. É sabido que em São Paulo, por exemplo, o contexto de formação de jovens artistas se dava no âmbito acadêmico, onde a reflexão crítica se 


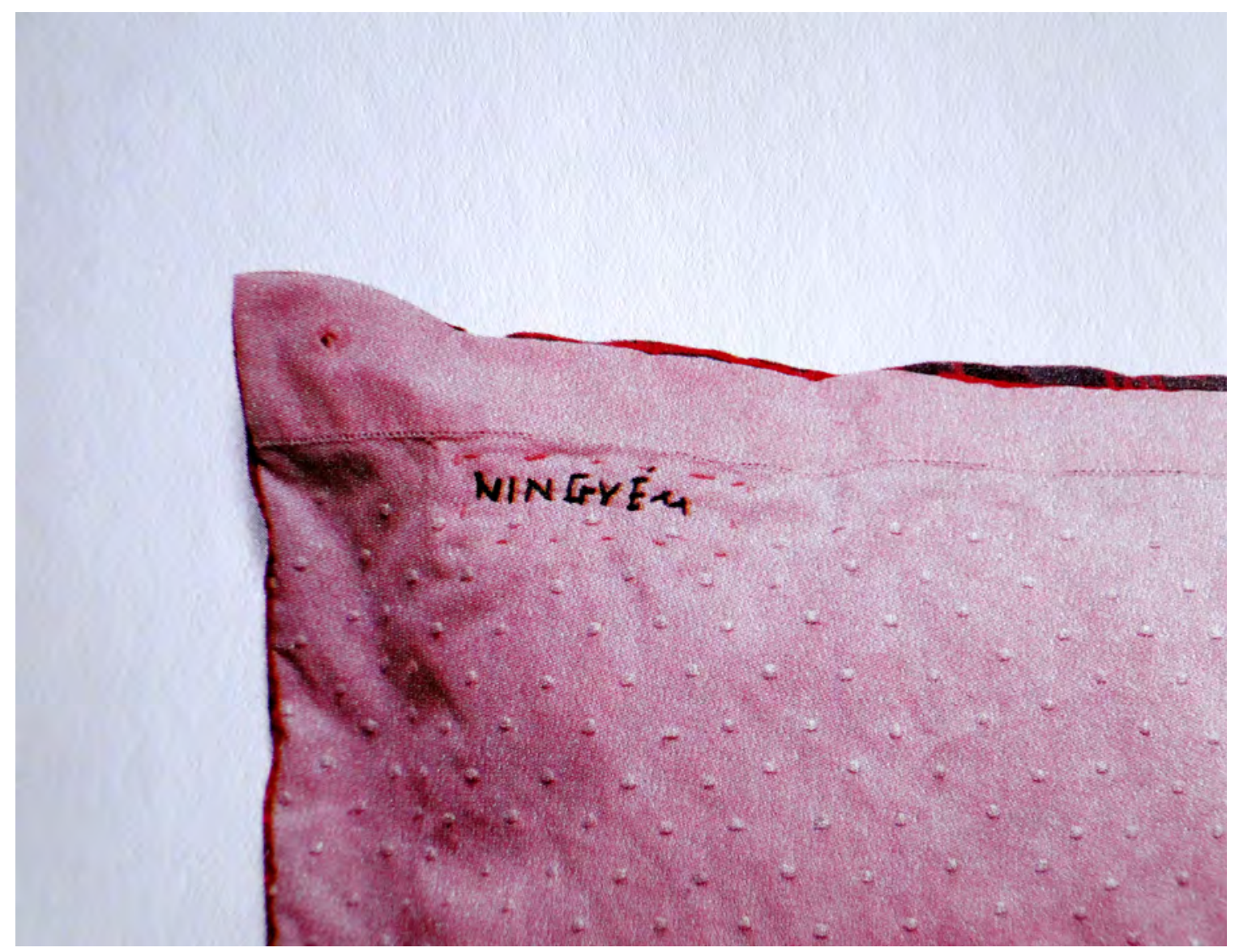

referia-se a um grupo de artistas cuja produção teve por ponto de partida o contexto carioca e favoreceu o retorno de um estilo de pintura fluída, "prazerosa", bem como da manualidade do fazer artístico, “[...] uma reação à arte hermética, purista, excessivamente intelectual predominante nos anos 1970"61. Embora tal pertencimento caracterizasse mais o início de sua carreira, Leonilson manteve e aprofundou sua investigação da linguagem pictórica, utilizando procedimentos que privilegiavam a manualidade e a incorporação de materiais do artesanato, da costura, bordado e tecelagem, sempre com um alto grau de subjetividade.

Uma importante pergunta gerada a partir da situação diz respeito a quais aspectos da obra de Leonilson se deixariam traduzir, ou atualizar, na obra de jovens artistas. Ainda, quais seriam os motivos para o cultivo de uma sobrevida, para além da homenagem? Para Li-

Detalhe da obra "Ninguém", 1992 Bordado s/ travesseiro, $24 \times 47,5 \mathrm{~cm}$. Col. Isa Pini, São Paulo. sette Lagnado, a obra do artista produziu um "excesso de apropriação da linguagem intimista”, gerando “toda uma 'academia' de diários bordados” (Lagnado 1998: 12). Apesar do risco de uma apropriação rasa, como apontada por Lagnado, Eduardo Brandão - sócio da Galeria Vermelho e propositor da exposição - viu na recepção ativa da obra um potencial a ser investigado:

manifestava igualmente em produções de obras de arte em vários suportes, meios e linguagens.

61 MORAIS, Frederico. Gute Nacht Baselitz ou Hélio Oiticica onde está você? In: BASBAUM, Ricardo (org.). Arte Contemporânea Brasileira. Rio de Janeiro: Ed. Marca D’água, 2001, p. 225. 


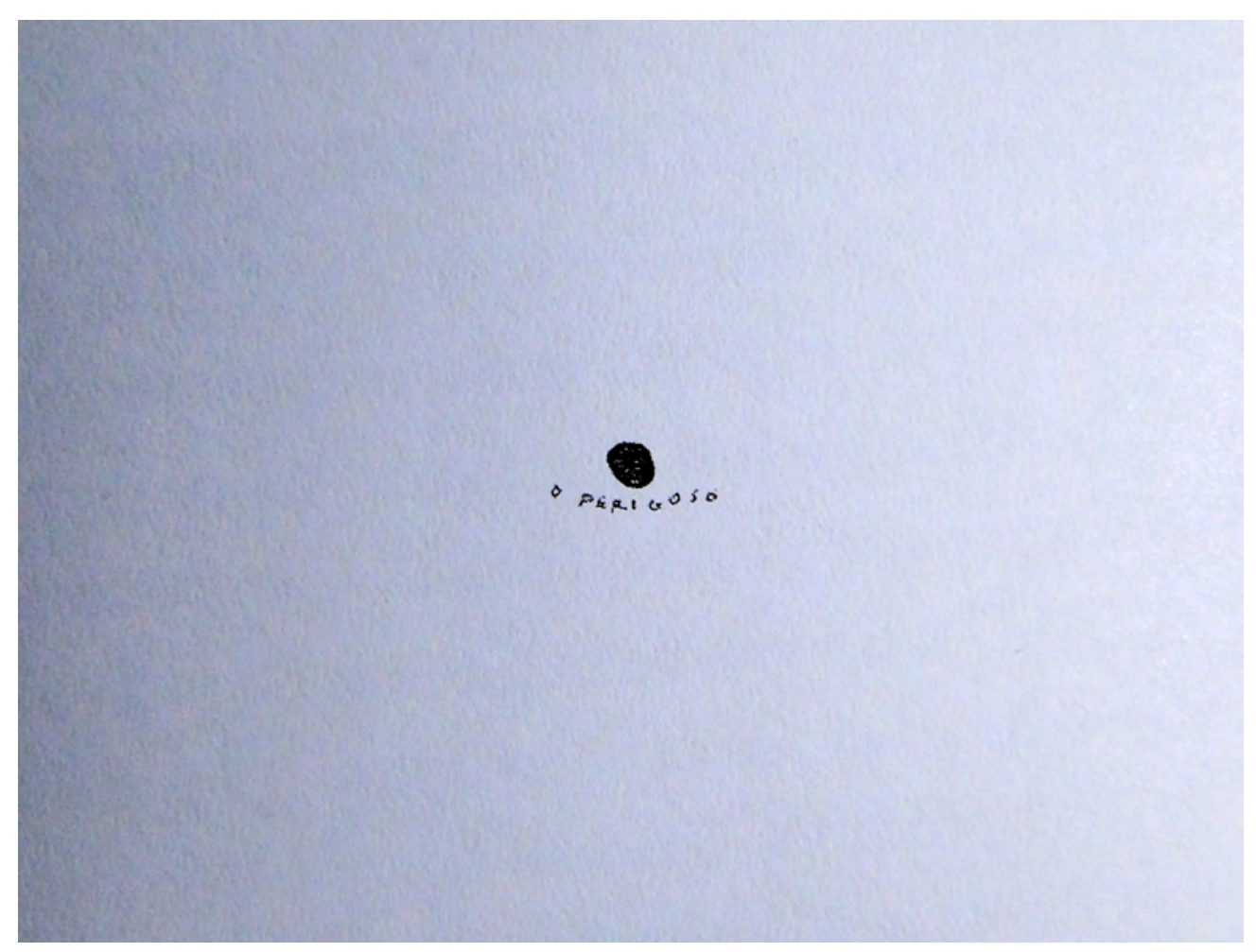

O Perigoso, 1992.

Sete desenhos sobre mesa de madeira realizados em nanquim e

sangue sobre papel. $30,5 \mathrm{~cm} \times 23 \mathrm{~cm}$ (cada). doença não apenas o acometeu, mas também influenciou seu trabalho, tornando-se motivo de reflexão. De acordo com o curador Ivo Mesquita: "Um sentido de vulnerabilidade permeia a última etapa da obra de Leonilson. A AIDS mudou o rumo de sua vida e marcou sua produção artística, conferindo-lhe uma terminologia final e irredutível"63. Na série “O Perigoso", a Aids é abordada na obra de forma explícita. Consiste em uma série de sete delicados desenhos. A particularidade é que o nanquim usado está misturado ao sangue de Leonilson, já contaminado. A associação entre a tinta e o sangue produz uma simbologia confessional, característica marcante na trajetória do artista.

62 BRANDÃO, Eduardo. In: ALZUGARAY, Paula (org.). Subjetiva Vizinhos - Catálogo da Exposição na Galeria Vermelho, São Paulo, 2003, p. 78.

63 MESQUITA, Ivo. Leonilson: use, é lindo, eu garanto. São Paulo: Ed. Cosac \& Naify, 1997, p. 9-14. 
Além da obra, depoimentos mais atuais ${ }^{64}$ sobre Leonilson estendem a questão da influência para a própria forma do artista estar no mundo. Para Jan Fjeld, amigo que acompanhou sua obra: "Se ele entrava em contato com alguém, que por alguma razão ele gostava, logo abria a porta... o que essa pessoa trazia de informações, de cultura, de opiniões, virava dele em dois minutos”. Essa característica porosa da personalidade do artista desloca a posição proposta na exposição Vizinhos - a do artista influente - para a daquele que foi influenciado. Nas palavras da artista e amiga de Leonilson, Leda Catunda:

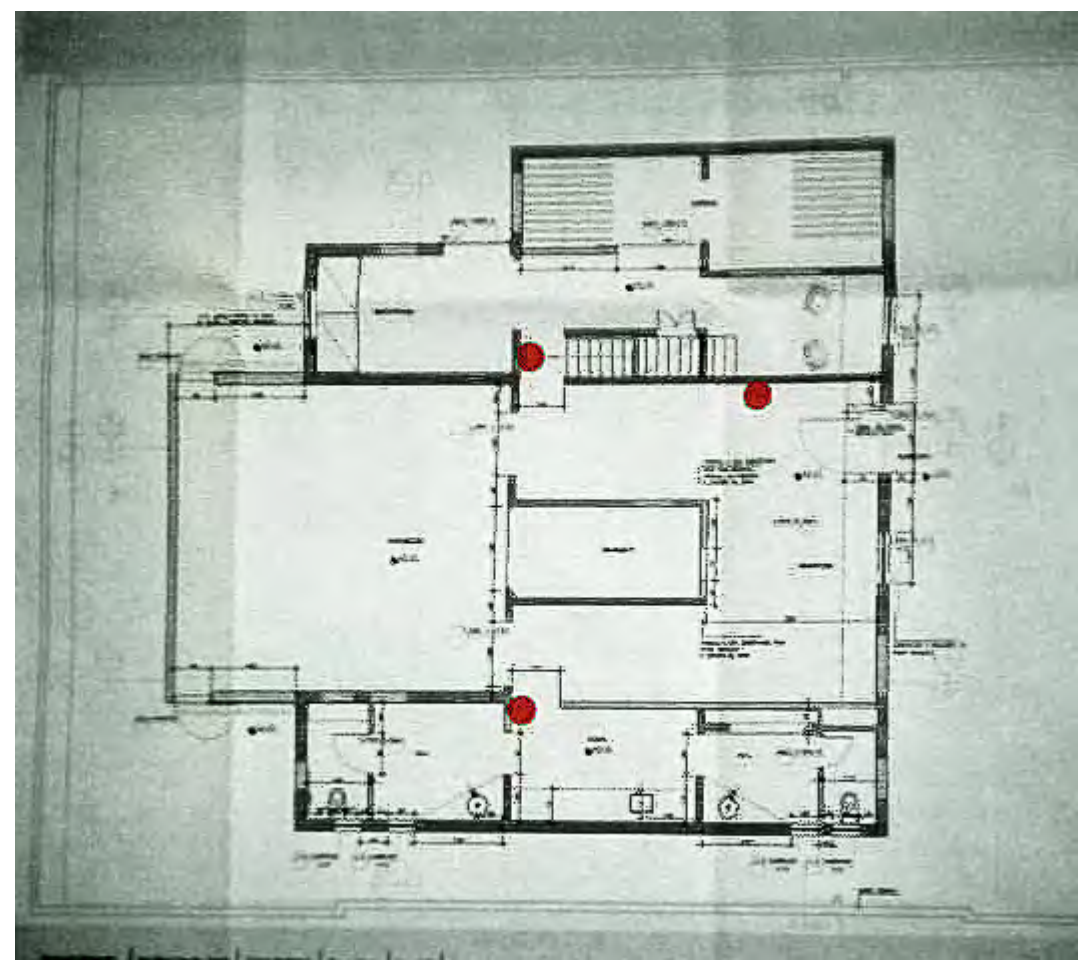

Mas o Leonilson era muito permeável, aberto a influências, [...] do tempo que nós convivemos, [...] ele veio mudando o trabalho muitas vezes [...] acho que isso é mais ou menos natural no trabalho de um artista, que se influencie pelo seu redor. Não existe um cara fechado, e o Leonilson se interessava muito pela linguagem, por exemplo, do Jorge Guinle, de quem ele não tem muita influência, [...] mas ele era amigo do Jorginho, e ele frequentava o atelier. Depois, o Antonio Dias, que fazia monotipias, [...] daí ele (Leonilson) vinha pra casa e fazia um pouco de monotipia. Tudo ele queria experimentar. Acho que era positivo, acho que agregava bastante ao trabalho. Mesmo essa coisa de ele começar a costurar, e usar os tecidos, [...] se me permite, ele ia nas lojas de tecido comigo. Ele já ia antes, mas depois que eu comecei a trabalhar sempre com tecido, nós íamos juntos, e aí no começo ele queria que eu costurasse pra ele na máquina. Eu costurei um ou outro, mas aí ele achou que ficava muito impessoal. Então ele começou a costurar à mão. Acho que eram sempre trocas saudáveis, eu nunca diria que o Leonilson copia, ou copiou. Ele se influenciava e modificava o trabalho dele.

64 Por ocasião da recente exposição sobre a obra de Leonilson no Itaú Cultural (SP), Sob o peso dos meus amores (2011), a artista Leda Catunda e Jan Fjeld - amigos pessoais de Leonilson - contribuíram com depoimentos em vídeo sobre as influências do artista. As referências a seguir são transcrições de suas falas: Capturado em 18 jun. 2011. Online. Disponível em: <http://www.itaucultural.org .br/leonilson/index. cfm/f/palavra/inluências.> 
A hobra que propus para essa exposição pretendia responder à constelação de problemas ora exposta. Era minha intenção tornar mais complexa a ideia de ser parte de um grupo de artistas que foram influenciados por Leonilson, condição na qual a proposta para participar do projeto já anunciava de antemão. Percebo, conforme mapeado pela curadoria, pontos de aproximação entre minha obra e a de Leonilson, principalmente na fase inicial da minha trajetória. No entanto, preocupações mais recentes em meu trabalho levaram a um processo de desidentificação de algumas questões recorrentes na obra do artista ou da leitura predominante que tem sido feita da mesma, tal como a ênfase dada ao tom existencialista e à relação com o fazer manual. O descolamento mostrou-se fecundo para criar um lado de fora ou uma área de reflexão crítica sobre a obra de Leonilson e a situação construída pela exposição. Evitava assim, o risco de uma abordagem excessivamente elogiosa do aspecto intimista e dócil de seu trabalho, característica da maioria das homenagens feitas na ocasião do décimo ano de seu falecimento.

\section{1 Área Semicrítica de Contaminação}

A hobra que apresentei recebeu o título de Área Semicrítica de Contaminação (A.S.C.). Consistiu na instalação de quatro dispositivos industriais de higiene manual em pontos estratégicos da Galeria Vermelho. Os aparatos não contavam com qualquer sinalização que os discriminasse enquanto obra. A única indicação de que faziam parte da exposição era um desenho arquitetônico da planta baixa em uma parede da galeria que mostrava os espaços onde os dispositivos estavam instalados. Junto ao mapa, havia um informativo técnico do produto, descrevendo as suas propriedades (imagens a seguir).

Em 2003, ano da exposição, dispositivos de assepsia não haviam ainda se popularizado. Isso viria a acontecer somente mais tarde, especialmente com a pandemia da Gripe A (H1N1) em 2009, cujo surto internacional fez proliferar o hábito de higienização das mãos com gel asséptico. $\mathrm{Na}$ época da exposição, tais aparatos costumavam ser usados 


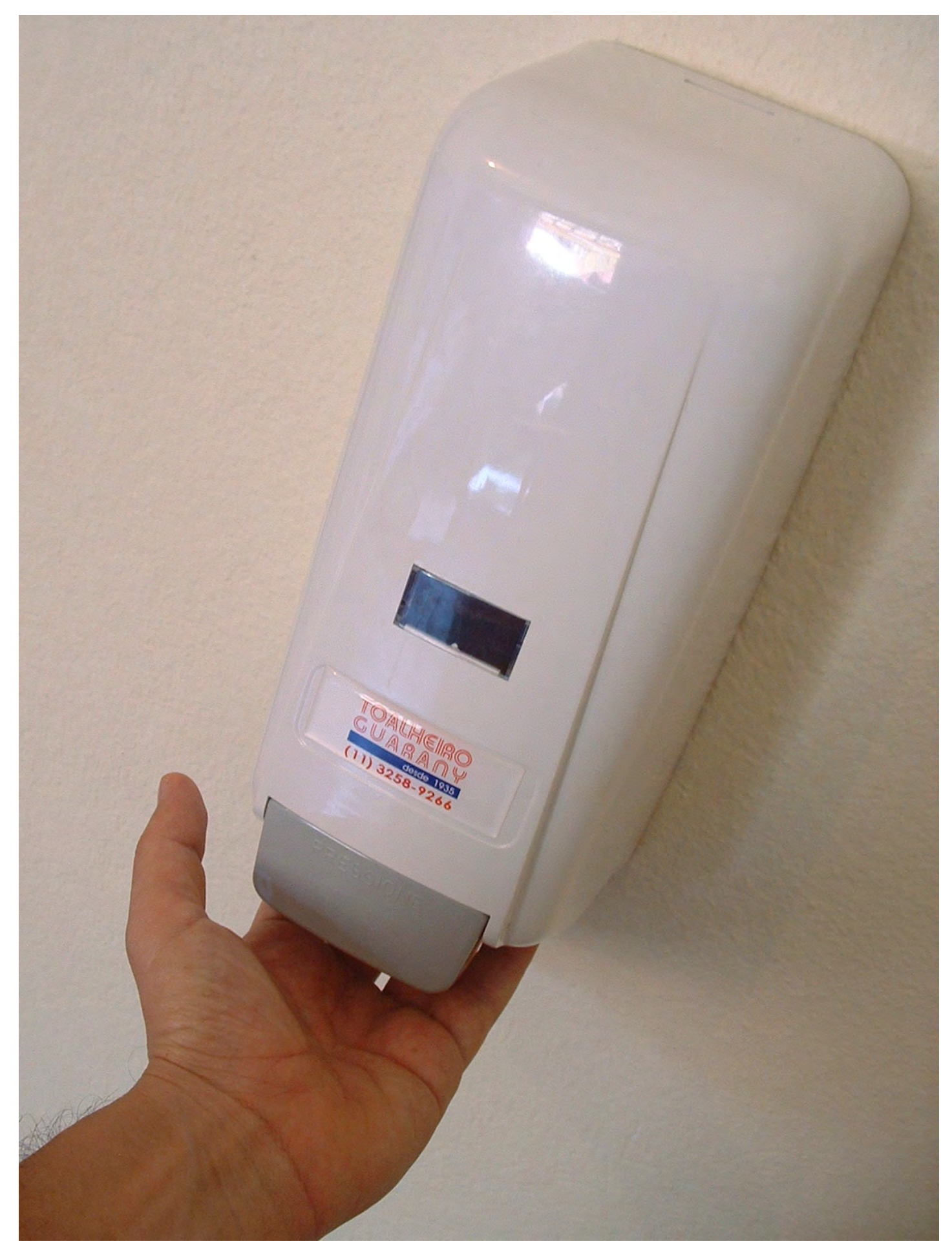




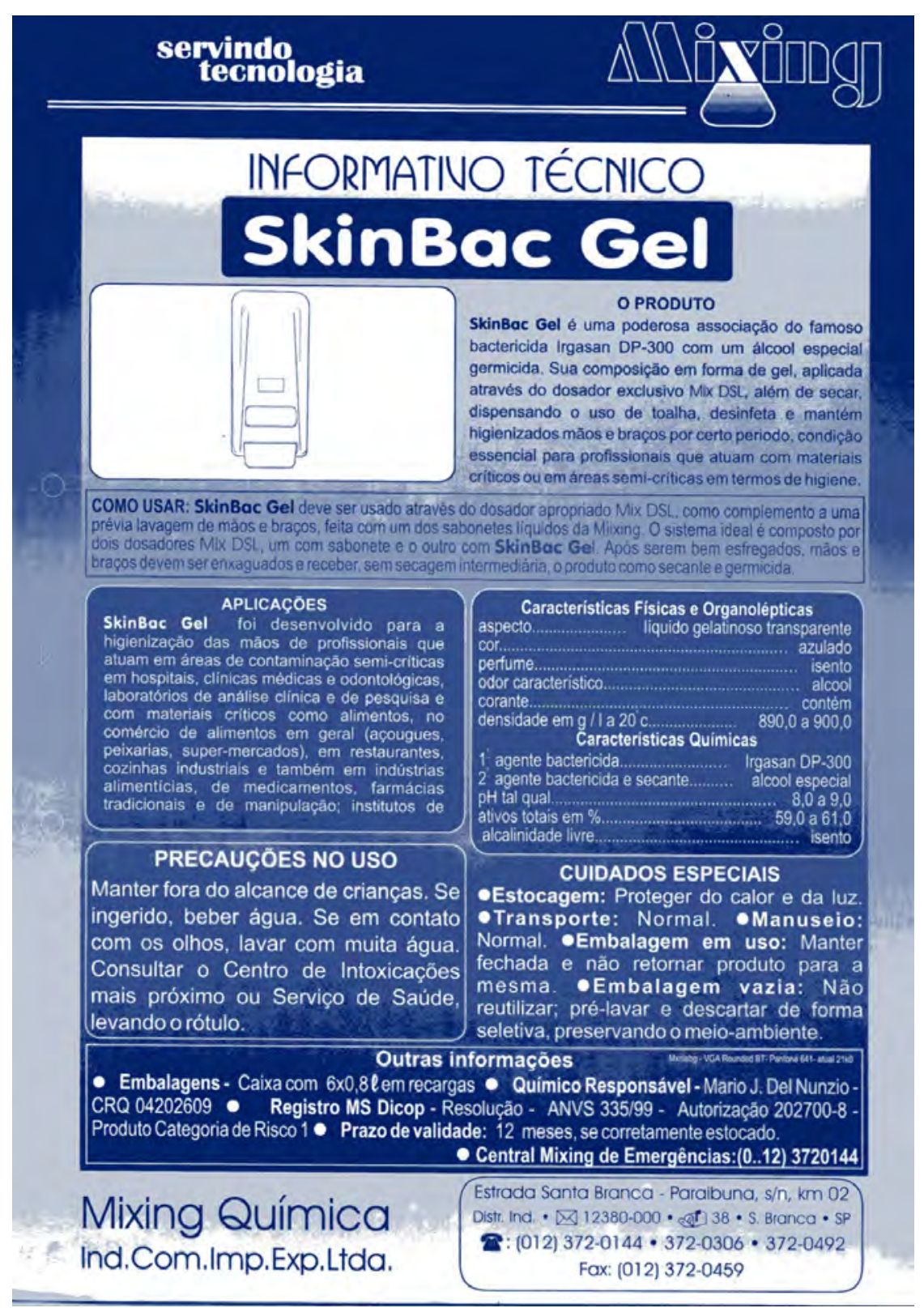

apenas em “áreas” consideradas "semicríticas de contaminação”. De acordo com o informativo técnico do produto utilizado na hobra, são estes:

\begin{abstract}
hospitais, clínicas médicas e odontológicas, laboratórios de análise clínica e de pesquisa e com materiais críticos como alimentos, no comércio de alimentos em geral (açougues, peixarias, supermercados), em restaurantes, cozinhas industriais e também em indústrias alimentícias, de medicamentos, farmácias tradicionais e de manipulação; $[\ldots]^{65}$.
\end{abstract}

A especificidade de uso tornava um tanto inusitada a presença dos dispositivos em uma galeria de arte contemporânea. A vizinhança forjada entre galeria e lugares de contaminação semicrítica - a partir do compartilhamento de um signo comum - pretendia criar um certo ambiente de suspeita característico daqueles espaços com risco de contágio. O gel asséptico se endereça a uma presença invisível, às bactérias que carregamos sem ver em nossas mãos e que podem se tornar perigosas, dependendo da situação onde estamos e do que manipulamos. Pode-se dizer que os aparatos contêm em si uma mensagem de alerta culturalmente construída: "você está em um lugar onde o uso das mãos traz riscos de contágio”. Os dispositivos operam portanto como sinalizadores de uma zona invisível, criando uma imagem mental que demarca uma área onde se deve estar atento ao que não se vê e combatê-lo.

65 Informe técnico do SkinBac Gel, produzido pela Mixing Química, São Paulo, e distribuído junto ao produto. 


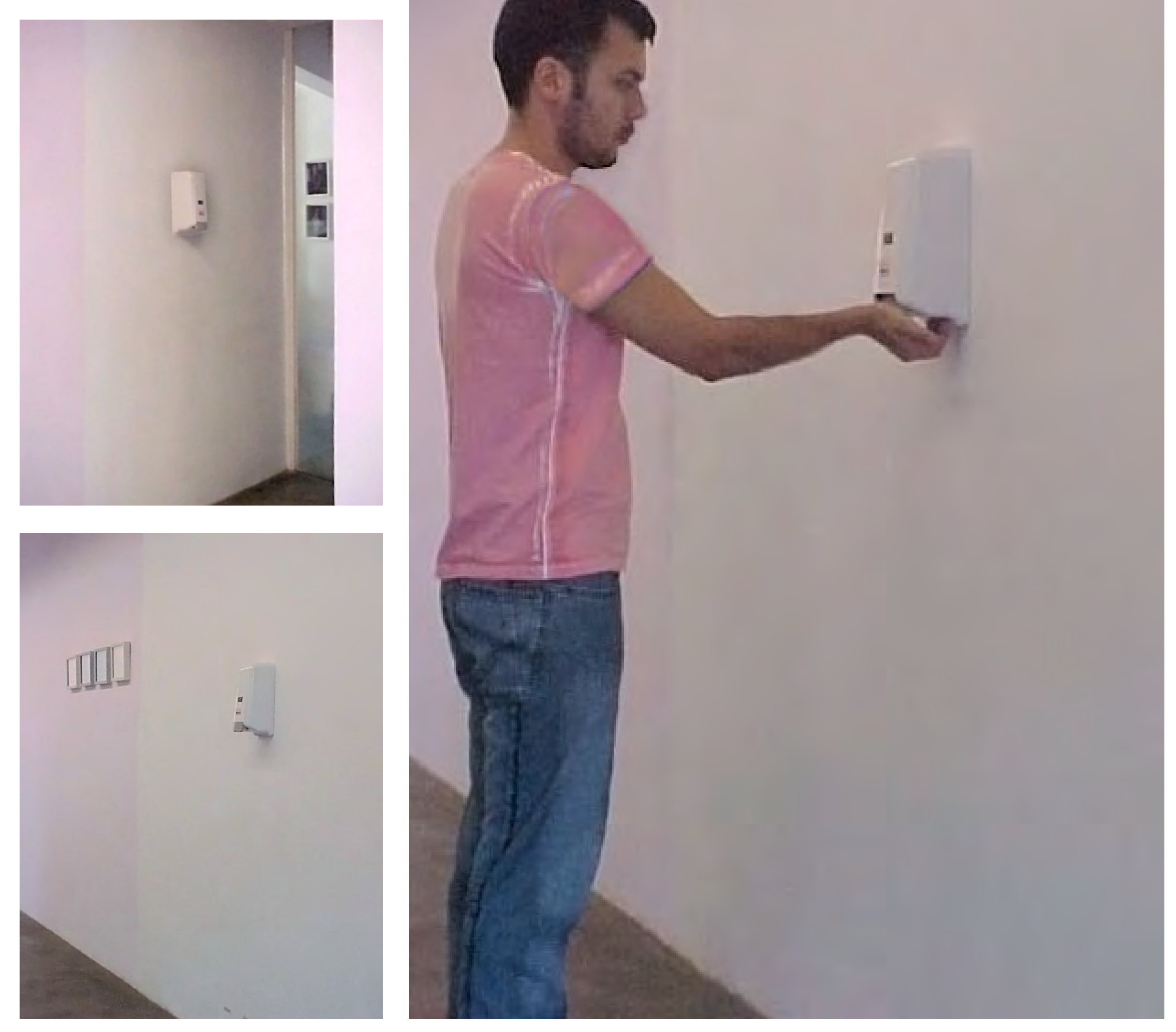



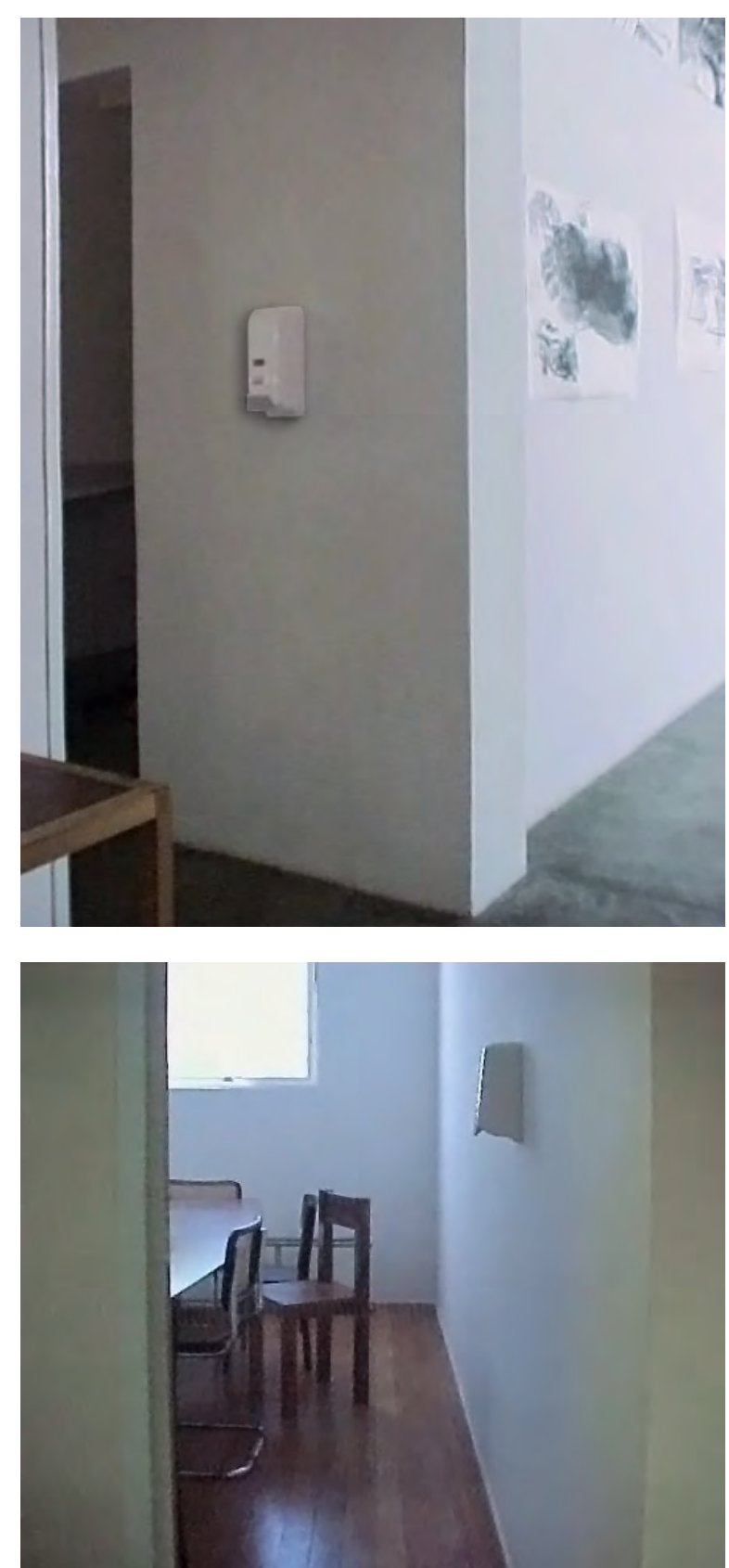

\subsection{A influência pela negatividade}

As relações de influência identificadas nas afinidades são as mais óbvias. A.S.C. opera a partir de um ponto de vista negativo, apostando em uma influência pelo avesso. São três os eixos principais a partir dos quais a hobra se organiza: a (não) manualidade, o (não) subjetivismo e a (não) objetualidade. A renúncia à manualidade é instaurada na forma de construção da hobra, a partir do deslocamento de um objeto industrializado e já pronto para as dependências da galeria. Numa associação rápida, tal deslocamento remonta ao readymade duchampiano. No entanto, diversamente, os dispositivos de higienização não sofrem uma desfuncionalização ou esvaziamento de sentido, como em Duchamp (o mictório deixa de ser funcional ao ser exposto). Ao contrário, os aparatos foram instalados na galeria tal qual teriam sido em outros estabelecimentos, e continuavam funcionando. O que acontece assim é uma expansão do raio de ação do objeto de maneira a incorporar um novo tipo de espaço, não mais associando-o somente às propriedades literais e comprováveis do produto, mas também à sua função simbólica e histórica.

A.S.C. não está relacionado a uma autoexpressão. Difere novamente da pulsão subjetivista de Leonilson, embora tal enquadramento possa ser redutor. Apesar de grande parte da sua produção ser autorreferente, o sujeito ao qual se refere já não apresenta um contorno fixo ou estável. De acordo com o curador Ivo Mesquita, o trabalho de Leonilson lida com o “conceito pós-moderno de self - deslocado, fragmentário, carregado de informação que parece ser importante e imediata,..." ${ }^{66}$. Assim, o artista também é espelho de sua época, permeado de exterioridade no que reflete.

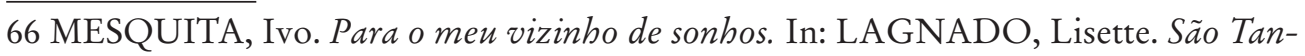
tas as Verdades. São Paulo: Ed. DBA/Fiesp, 1998, p.193. 
A própria questão da AIDS na sua obra transcende o drama pessoal e se insere no corpo social, unindo Leonilson a outros artistas de seu tempo no empenho de "politização da linguagem plástica" ${ }^{67}$.

De todo modo, a proposta de limpar as mãos de quem dispara os dispositivos de gel asséptico sugere uma relação com a expressão “estar de mãos limpas”. No português, a ideia adquire diversas conotações. Entre elas está a de uma isenção de autoria, ou do envolvimento das mãos do sujeito em algo que foi feito. Lavar as mãos, nesse sentido, é uma expressão usada para não implicar-se diretamente em um fato, ou acontecimento. Finalmente, a terceira negação em A.S.C. é aquela da objetualidade. Conforme descrito, não pretendia que os dispositivos de gel asséptico deslocados para a galeria fossem entendidos como um objeto de arte ou a própria hobra. Por isso, o cuidado de não sinalizá-los com etiquetas enquanto tal. A intenção era de que tais dispositivos operassem na criação de um território, de um ambiente ou de uma área - como o título indica. Sendo assim, a hobra não era objetual, e só existia em relação à proposta curatorial, à galeria, ao seu momento histórico e à obra de Leonilson.

As múltiplas estratégias de apagamento das relações mais explícitas com a obra de Leonilson, a partir das negações descritas, não estariam completas se não apontassem para o espaço que restou, esvaziado pela desidentificação. $O$ vazio gerado não pretendia produzir silêncio e nem tinha a negação como um fim em si. O que se desejava era uma qualidade de vazio-vácuo que tivesse a força de sugar um novo sentido, uma nova leitura, algum frescor rejuvenescedor. No entanto, o que se quer reviver não é mais um autor e seus hábitos, mas um lugar frequentado por ele: uma área de inconformidade; um certo estado de "outsider" (Lagnado 1998: 69) - qualidade nem sempre celebrada em Leonilson, mas cuja influência A.S.C. não negará. 


\section{Anotações}

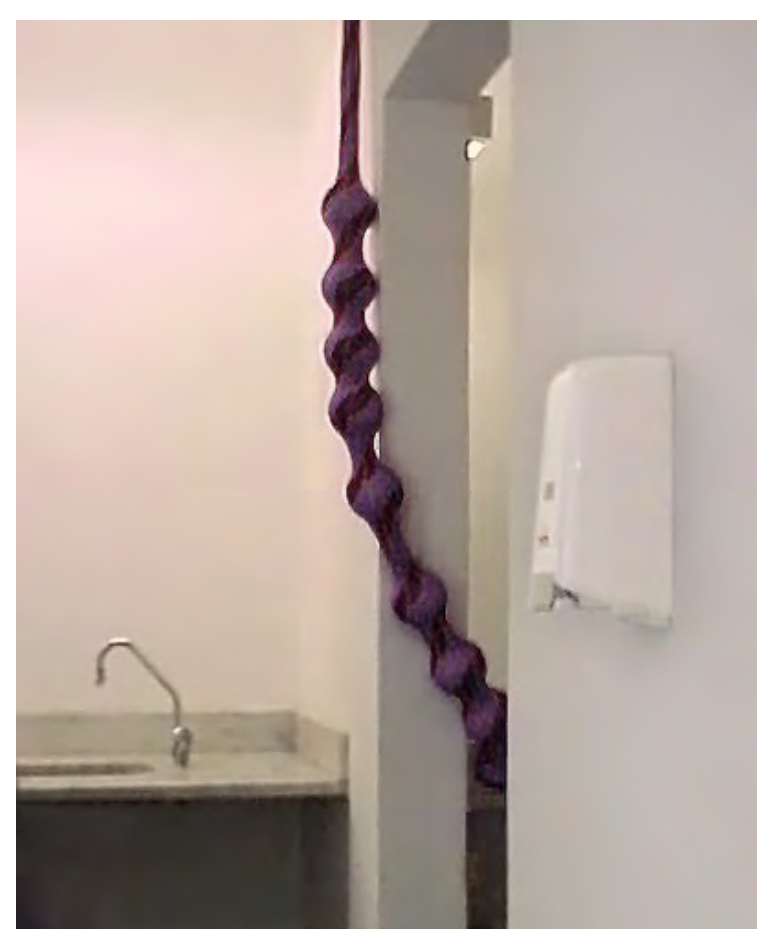

Dispositivo instalado na Galeria Vermelho. Ao fundo, detalhe da obra do artista Renato Dib, que também participava da mostra.
+ A substituição da ideia de um autor por um espaço me foi sugerida pela leitura do artigo $O$ que é um autor? de Michel Foucault: "Mas não basta, evidentemente, repetir como afirmação vazia que o autor desapareceu. Igualmente, não basta repetir perpetuamente que Deus e o homem estão mortos de uma morte conjunta. $\bigcirc$ que seria preciso fazer é localizar o espaço assim deixado vago pela desaparição do autor, seguir atentamente a repartição das lacunas e das falhas e espreitar os locais, as funções livres que essa desaparição faz aparecer"68.

+ Algo proposto por A.S.C. é o entendimento da própria exposição enquanto uma área semicrítica de contaminação. Poderiam as obras ali expostas serem consideradas como uma leitura crítica do trabalho do artista ou correriam o risco de operar enquanto uma "releitura", uma "apropriação", ou até uma "ilustração", dada a moldura curatorial? $\bigcirc$ que caracterizaria uma abordagem crítica da obra de Leonilson? A exposição poderia propor um olhar crítico sobre o tipo de herança deixada pelo artista? Ou seria uma celebração da sua obra e uma forma de lembrá-lo afetivamente? $\bigcirc$ texto dos curadores se dirigia, de uma certa forma, a tais problemas: "A referência a Leonilson é menos uma homenagem que uma constatação da sua fecundidade. Os caminhos abertos pela sua obra trazem a possibilidade de sua continuidade e superação. $\bigcirc$ devir e o porvir são vislumbrados nas lacunas de seu trabalho, nas portas e janelas que criou"69.

68 Foucault, Michel. Ditos e Escritos: Estética - literatura e pintura, música e cinema (vol. III). Rio de Janeiro: Ed. Forense Universitária, 2001, p.264-298. Capturado em 05 set. 2011. Online. Disponível em: $<$ http://fido.rockymedia.net/anthro/foucault_autor.pdf>

69 Texto dos curadores. In: ALZUGARAY, Paula (org.). Subjetiva Vizinhos - Catálogo da Exposição na 
+ É importante assinalar que uma metodologia de recuperação da história ${ }^{70}$ também está presente na proposta curatorial do projeto. Para citar um outro caso semelhante, em recente exposição no MAM-SP, o curador Inti Guerrero realizou uma curadoria que pretendia revisitar a tradição, a partir de algumas questões do trabalho de Flávio de Carvalho (1899-1973). A exposição mostrava apenas uma obra de Flávio, o desenho "New Look (1965), que apresenta um traje executivo masculino, concebido especificamente para as condições climáticas, econômicas e culturais do homem urbano nos trópicos" . O curador propôs uma constelação de obras de outros artistas que de alguma forma pudessem ser lidas em diálogo com Carvalho, mais especificamente em relação ao seu projeto A Cidade do Homem Nu, no qual o artista propunha um novo modelo de urbanismo e moradia,"sem tabus escolásticos, livre para pensar e raciocinar". A metodologia curatorial elegida por Guerrero buscou, "ao invés de 'ilustrar' o pensamento de Flávio Carvalho [...] construir o significado radical e contracultural do seu urbanismo, abrindo possibilidades de imaginar como poderia ser aquele lugar'"7|. Temos assim um contexto de remissão, de questionamento, que inflama e autoriza uma influência, trazendo-a para o tempo presente, ao mesmo tempo em que afirma o seu lugar na tradição.

Galeria Vermelho, 2003, p. 78.

70 Para Julio Plaza, "Recuperar a história é estabelecer uma relação operativa entre passado-presente-futuro, já que implica em duas operações simultâneas e não antagônicas: de um lado, a apropriação da história, de outro, uma adequação à própria historicidade do presente, estratégia essa que visa não só vencer a corrosão do tempo e fazê-lo reviver, mas visa também sublinhar que as coisas somente podem voltar como diferentes". PLAZA, Julio. Sobre Tradução Intersemiótica. 1984, (303 pgs.). Tese de Doutorado em Comunicação e Semiótica. PUCSP, São Paulo, 1984, p. 7.

71 GUERRERO, Inti. A Cidade do Homem Nu. Catálogo da Exposição. Museu de Arte Moderna. São Paulo, 2010, p. 10. 
grounds where books were considered with suspicion.

Gonzalez-Torres: It's a queer thing, I mean, at least from my background.

Rollins: I think it's about wanting a larger world. I think it's about wanting to be involved with the world of ideas, and it takes a certain amount of courage to really go into that other land. That's the danger of being too involved in theory: you get to a certain level in your education where you equate theory with practice.

Gonzalez-Torres: Tim. Imust say that without reading Walter Benjamin, Fanon, Althusser, Barthes, Foucault, Borges, Mattelart, and others, perhaps I wouldn't have been able to make certain pieces, to arrive at certain positions. Some of their writings and ideas gave me a certain freedom to see. These ideas moved me to a 


\section{A TRADUÇÃO COMO UMA FORMA DE PARTICIPAÇÃO CRÍTICA: FELIX GONZALES-TORRES}

Felix

$7^{\text {a }}$ Bienal de Havana (2000)

A hobra Felix foi especificamente desenhada para a VII Bienal de Havana em 2000. O tema da bienal era Más cerca uno del otro [mais próximo um do outro] e pretendia investigar relações de proximidade entre artista, obra e público. Tendo sido convidado a participar, propus mais um tipo de acercamento possível: aquele entre artista e artista. $\mathrm{O}$ projeto que apresentei previa uma aproximação da obra de Felix Gonzales-Torres (19571996). Além de um interesse pessoal, algumas questões presentes no trabalho do artista cubano, naturalizado norte-americano - tal como as diferentes qualidades de participação do público -, pareceram-me interessantes de serem revisitadas no contexto curatorial da bienal.

Muitas das obras de Felix Gonzales-Torres convidam o público a interagir de muito perto, completando o trabalho a partir de uma interação bastante próxima. O visitante costuma ser convidado a levar a obra - ou pedaços dela - para casa e dar-lhe a continuidade que desejar. A obra Untitled [passport], 1991, por exemplo, consiste na disposição de uma pilha de papéis brancos $(59 \times 59 \mathrm{~cm})$ em um determinado espaço expositivo. As folhas são deixadas à disposição e repostas infinitamente. Com estratégia similar, o artista também trabalhou com doces. Na obra Untitled [Lover Boys], 1991, uma quantidade específica de balas de açúcar é empilhada em um canto de uma galeria. O público é incentivado a consumi-las, enquanto o museu ou galeria as repõe, de modo a manter-se a mesma quantidade exposta. Seja enquanto um simples consumidor ou um visitante especializado, fica explícita a importância da ação do espectador para que a obra se complete. Seus trabalhos 


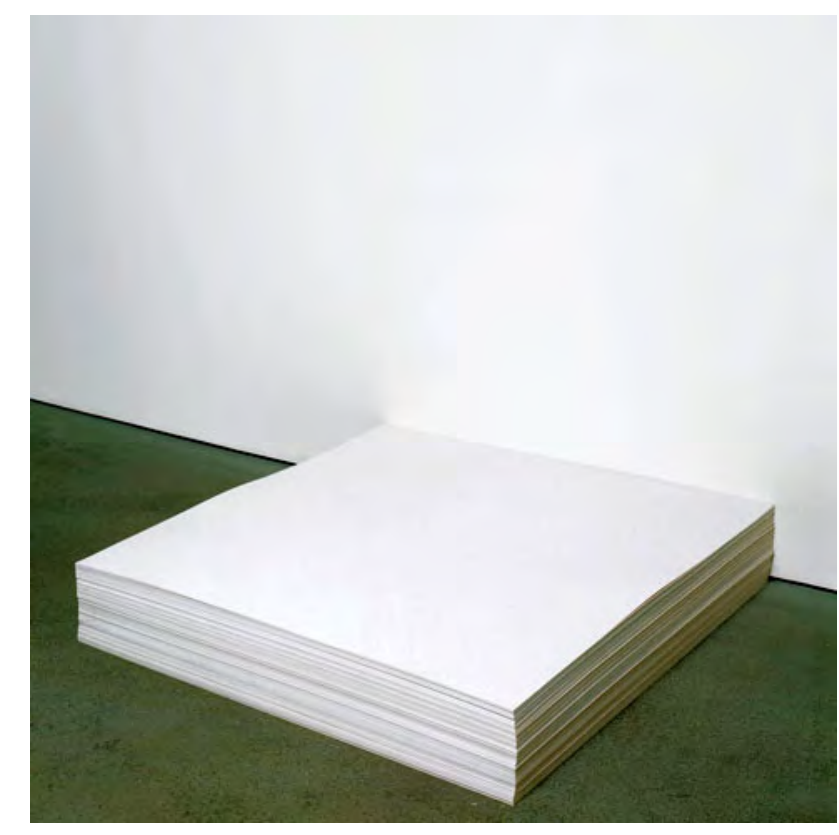

Untitled [passport], 1991, Felix Gonzales-Torres. provocam a "voracidade do público"72, mas ao mesmo tempo são refeitos até serem novamente consumidos.

Minha aproximação da obra de Felix Gonzales-Torres se deu por afinidade a partir de um projeto desenvolvido em 1998 chamado con-fio. Consistia em $400 \mathrm{~kg}$ de cobre fundido em tijolinhos maciços que cabiam na palma da mão. Carregavam as inscrições "con" e "fio", alternadamente. Foram realizados para uma exposição chamada Remetente, quando eram distribuídos para os visitantes da mostra e artistas participantes. Remetente foi proposto por um grupo inicial de seis artistas. A ideia era criar uma rede de afinidades, tecida a partir de convites feitos por cada um dos integrantes originais. O critério de escolha do artista a ser convidado era pessoal e se baseava, principalmente, na percepção de uma afinidade entre processos de trabalho, interesses e um desejo de aproximação. Cada convidado também podia chamar mais um outro, formando assim uma exposição coletiva de dezoito artistas. Muitas vezes, a escolha não levava em conta a proximidade geográfica do artista escolhido. A configuração final da rede incluía artistas de vários cantos do país e uma artista francesa. O braço da rede que me incluiu era composto por Laura Fróes, do grupo original, e Tunga, meu convidado. A escolha dos artistas para o projeto, geralmente atribuída a uma curadoria, ficou a cargo dos próprios artistas. Remetente apostou assim, em uma possibilidade de agrupamento, cujo critério emergia a partir dos próprios processos de trabalho e miradas. $\mathrm{O}$ resultado foi um grupo heterogêneo, sem uma amarração conceitual explícita. Relações podiam ser traçadas, mas muitas vezes eram secretas ou apenas insinuadas. A rede do Remetente era uma de afetos e influências.

72 CRUZ, Amanda In: FERGUSON, Russel (ed.). Felix Gonzales-Torres. Catálogo da exposição. Museu de Arte Contemporânea de Los Angeles, 1994, p.16. 

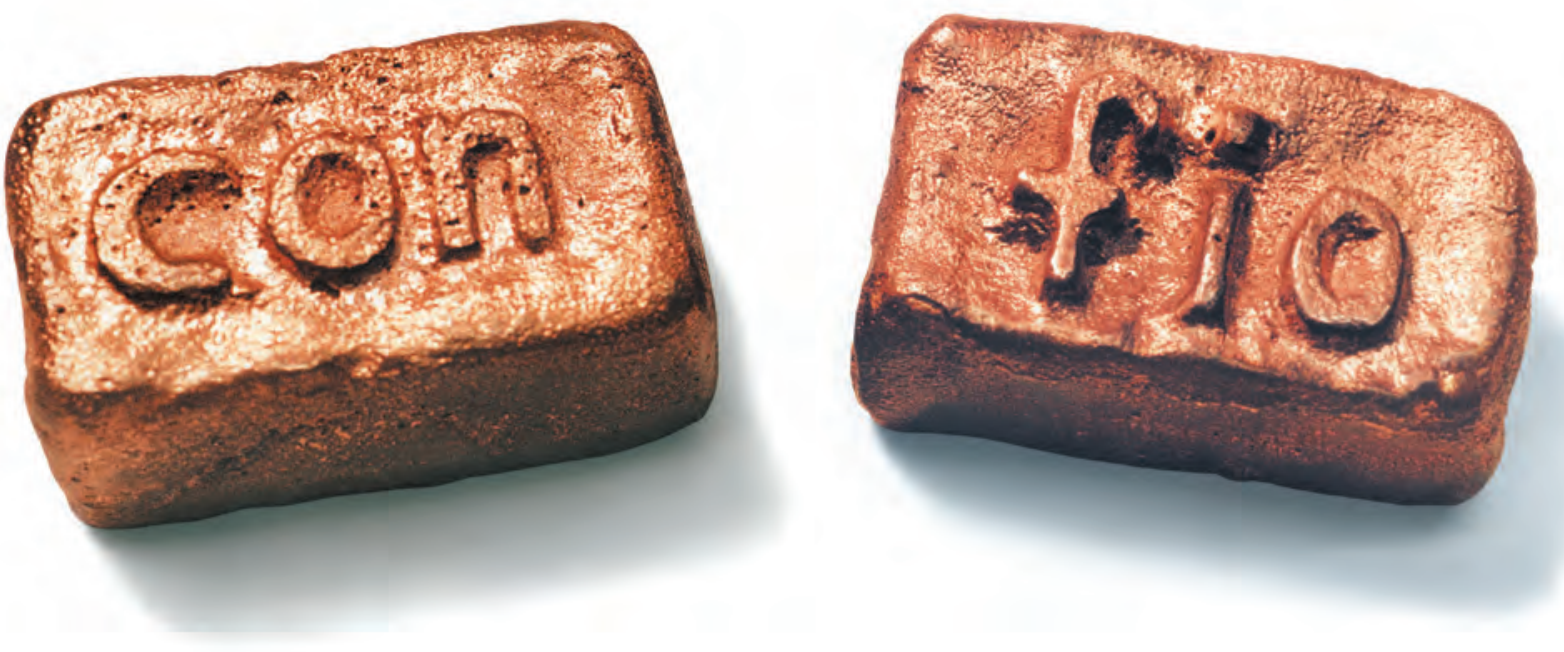

con-fio, 1998, Jorge Menna Barreto.
A remoção dos tijolinhos con-fio do ambiente expositivo encontrava na casa do visitante o seu ponto de deposição. A expansão do ambiente da obra, provocada por tais deslocamentos, também era um motivo de grande interesse. A situação doméstica em que muitos dos tijolinhos acabavam, passíveis aí de adquirirem outros acoplamentos, usos e agenciamentos (uma espécie de participação prolongada na obra), lançava o trabalho em um processo infinito de transformações e reconfigurações. No espaço doméstico, era o participador quem definia os novos limites do trabalho, sua temporalidade e seu sentido, longe do lugar controlado e temporalmente delimitado do espaço expositivo: "Tudo torna-se parte de uma rede íntima, tecida entre o artista, o público e o mundo"73.

A ideia de participação é cara, seja em relação a Felix Gonzales-Torres, seja ao con-fio. Para o artista Hélio Oiticica (1937-1980), entre as muitas maneiras de participação, há duas que são bem definidas: uma é a que envolve manipulação, ou participação sensorial corporal; a outra, que envolve uma participação semântica. Para Oiticica, os dois modos "não se reduzem ao puro mecanismo de participar, mas concentram-se em significados novos, [...]” (Oiticica 1986: 91). É questionável, assim, se o fato de levar um con-fio para casa, ou comer um dos doces de Felix Gonzales-Torres em uma exposição,

73 FERGUSON, Russel (ed.). Felix Gonzales-Torres. Catálogo da exposição. Museu de Arte Contemporânea de Los Angeles. 1994, p. 33. 


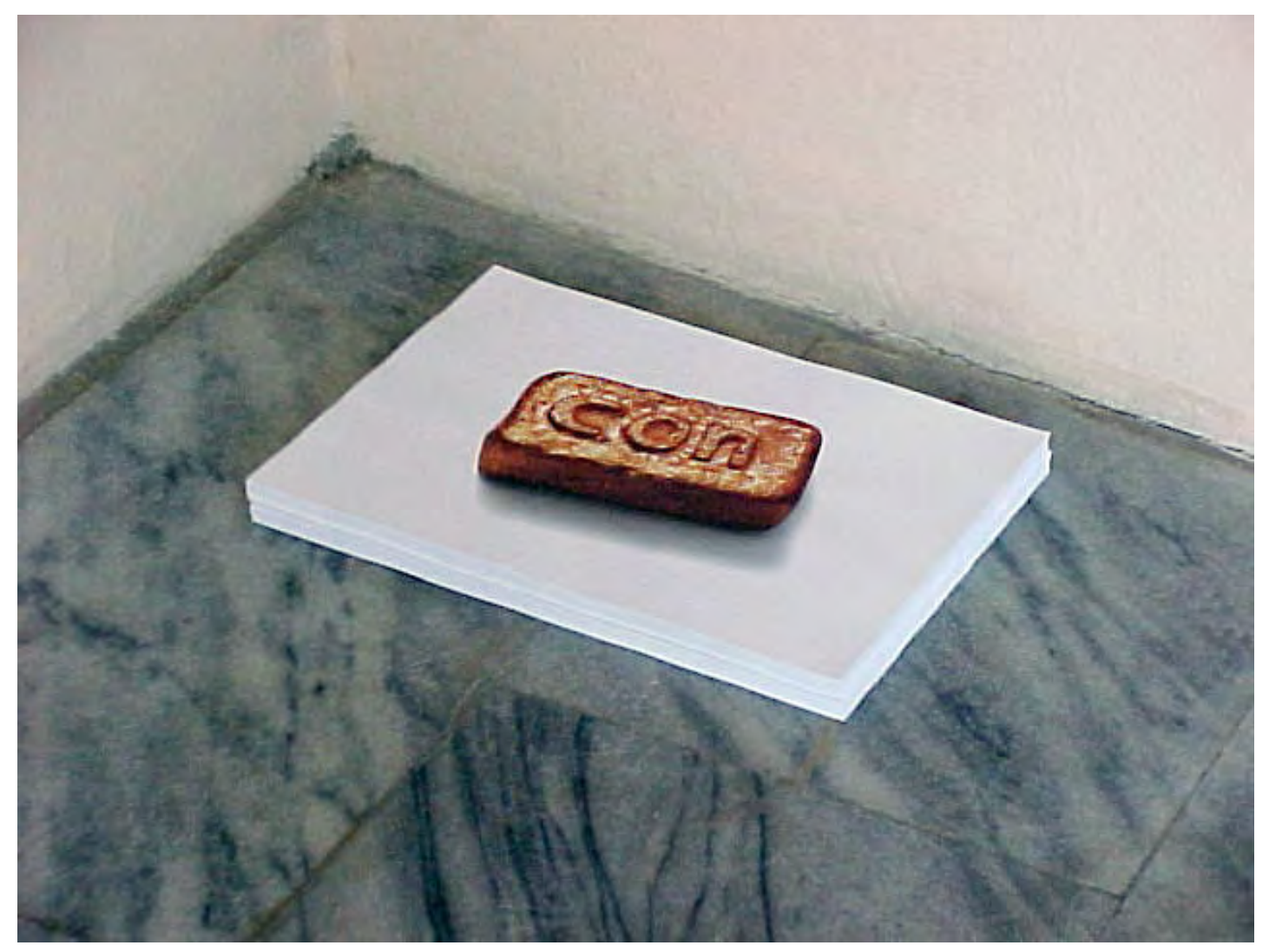

garantiria a participação nestas obras. De uma certa maneira, a ideia de participação, assim entendida, parece restrita. Semelhante ao que diz Cauê Alves em relação à banalização atual da participação na obra de Hélio Oiticica: “toda ação do sujeito já está prevista anteriormente” (Alves 2009: 3). Ou seja, o visitante está simplesmente completando um passo do script dado pela obra, já previsto pelo autor. O público permanece assim no campo de problemas proposto pela obra. Sua emancipação como produtor de sentido só se dará a partir do momento em que começa a inventar novas formas de participação, quando inaugura o seu próprio campo de atuação, não necessariamente previsto pelo propositor.

Felix, 2000, Jorge Menna Barreto.

\subsection{A hobra}

A hobra que propus para a Bienal de Havana consistia não somente em uma aproximação com o trabalho de Felix Gonzales-Torres, conforme já dito, como também em um desdobramento da obra con-fio. O uso do primeiro nome do artista para dar o título à hobra revelava a intenção de acercamento. A hobra Felix consistiu na impressão de uma fotografia do con-fio, "con" e "fio" separadamente, sobre folhas de papel branco nas dimensões $30 \mathrm{~cm}$ x $40 \mathrm{~cm}$. As pilhas foram dispostas em dois recintos distintos de um mesmo espaço expositivo em Havana. A maneira de expor o trabalho, correndo o risco de que a palavra não fosse completada, alargava as suas possibilidades como sílabas livres para outras conexões. Tal como em algumas obras de Felix Gonzales-Torres e em con-fio, 
the Cuban revolution, Santeria, and other issues. This movie is very interesting because it's also about the meaning of love during a particular historical period. I saw that movie the same week that I saw Hiroshima, Mon Amour.

Rollins: That's a great movie about love.

Gonzalez-Torres: No, it's about meaning and how meaning is dependent on the context. Last but not least, Brecht is an influence. I think if I started this list of influences again, I would start with Brecht. I think this is really important because, as Hispanic artists, we're supposed to be very crazy, colorfulextremely colorful. We are supposed to "feel," not think. Brecht says to keep a distance to allow the viewer, the public, time to reflect and think. When you get out of the theater, you should not have had a catharsis; you should have had a thinking experience. More than anything, break the pleasure of representation, the pleasure of the flawless narrative. This is not life; this is just a theater piece. I like that a lot: this is not life; this is just an artwork. I want you, the viewer, to be intellectually challenged, moved, and informed.

\section{Rollins: Some people don't like that.}

Gonzalez-Torres: Of course not, because they have an investment in the narrative. The artist is expected to be someone who "feels," the idiot savant. I admire artists that break the rules, that break with the expected functions of an artist, that push the limits of artistic practice; artists that can recite economic facts at the drop of a hat; artists that can tell you how much money has been eliminated

Foto da pag. 87 do livro Between Artists, que contém uma entrevista de

Felix Gonzales-Torres concedida a Tim Rollins (1996) ${ }^{76}$ a hobra Felix também podia ser levada pelo público visitante. No entanto, as pilhas não eram repostas. Foram impressas duas pilhas de 3.000 folhas cada.

Nas diversas situações descritas até agora, nas obras con-fio, Untitled [Lover Boys], Untitled [passport]; no tema da Bienal de Havana Más cerca uno del otro, no Projeto Remetente e em Felix, parece que há um elogio implícito à ideia de aproximação, como se fosse algo intrinsecamente positivo. No entanto, "Brecht diz para manter uma distância, para permitir ao espectador, ao público, tempo para refletir e pensar"74, enuncia o próprio Felix Gonzales-Torres sobre o dramaturgo alemão em sua entrevista com Tim Rollins, no trecho fotografado ao lado. O artista cita Brecht como uma maneira de justificar o rebaixamento do apelo visual em muitas de suas obras, o que iria de encontro à expectativa que se tem em relação a artistas latinos, que deveriam ser "extremamente coloridos" 75 e sedutores.

No caso de Felix Gonzales-Torres, é interessante considerar o quan-

74 RODNEY, Sappington (ed.). Between Artists. Los Angeles: Ed. Art Press, 1996, p. 87 (tradução minha).

75 Ibid., p.87.

76 Em português: "Brecht diz para manter uma distância para permitir ao espectador, ao público, tempo para refletir e pensar. Quando você sai do teatro, não deveria ter tido uma catarse; deveria ter tido um experiência pensante". RODNEY, Sappington (ed.). Between Artists. Los Angeles: Ed. Art Press, 1996, p. 87 (tradução minha). 
to esse enxugamento de um estímulo retiniano não é compensado, sensorialmente, pelo convite à interação literal em suas obras. Levar a obra para casa e até mesmo degluti-la são estratégias para alimentar um tipo de proximidade bastante intensa, uma fusão com o público. É claro que a distância ideal para uma obra manter o seu tônus e não ser banalizada como "docinhos que são distribuídos gratuitamente" varia de acordo com o visitante. No entanto, é questionável se os apelos para uma obra manter o seu poder de afeto e influência não acabam por sufocar a possibilidade de instaurar uma distância fértil e provocativa.

O paradoxo proposto em Felix diz respeito às ideias de aproximação e distância da obra de Felix Gonzales-Torres. Realizei a hobra Felix sem nunca ter visto ou experienciado um trabalho de Felix Gonzales-Torres ao vivo. Meu contato com a sua produção até então havia sido a partir de livros, revistas e internet. Talvez não fosse tão grave se estivéssemos tratando de uma obra cujo suporte é a fotografia, que costuma ser mais bem traduzida em catálogos. O paradoxo coloca-se ao se reinvidicar uma aproximação que não se dá pela participação literal, mas pelo reconhecimento no outro de algo experienciado em minha própria trajetória. De certa forma, embora não tivesse ouvido falar da obra de Felix Gonzales-Torres quando realizei con-fio, minha obra já continha um outro, sem que eu o soubesse. A relação se dá em nível embrionário, como possibilidade de uma leitura que avizinha. No entanto, a aproximação que se dá posterior ao reconhecimento não é da ordem da participação direta, como público, mas a daquela de leitor do que foi publicado sobre ela: uma posição distante da experiência da obra. Mesmo que se possa culpar as razões geográficas ou a carência dos nossos museus pela falta de um Felix Gonzales-Torres que estivesse mais próximo, a distância não se mostra improdutiva para realizar a tradução pretendida. Ou seja, ela é incorporada como uma desexperiência que busca o lado reverso de uma participação como pura proximidade, reivindicando distância. 


\section{Anotações}

+ Há uma duplicidade na voz da hobra Felix, a qual leva por título o primeiro nome de outro artista. A duplicidade de autoria é típica de traduções, onde original e tradução convivem: Felix é uma hobra "que não esconde a duplicidade da sua autoria" (Lages 2002: 84)]

+ A imagem do con-fio sobre a pilha de papel já anunciava uma certa contradição ao ato de distribuição. Embora não diretamente intencionado, e tendo ficado mais claro no ângulo em que foram tiradas as fotos das pilhas do que na experiência da hobra, o tijolinho impresso na folha pode ser confundido com um peso sobre a folha. Em uma leitura possível, a adição da imagem do con-fio não contribui para a dispersão das folhas, mas para uma desaceleração, uma contenção trazida por um peso que the é agregado.

+ A tradução do texto contido na obra con-fio traz questões interessantes sobre os jogos de perdas e ganhos nos processos tradutórios. No português, ao quebrar-se a palavra confio, gerando as sílabas "con" e "fio", revela-se a palavra "fio", rica em significado e que agrega novos sentidos ao contexto da exposição proposta em formato de rede para a qual a obra foi pensada. No entanto, a palavra "con" em português não tem um significado autônomo, ou seja, não é uma palavra, mas um prefixo. Ao ser apresentada num contexto de língua espanhola, como a Bienal de Havana, o jogo com a palavra "fio" se perde. Em espanhol, existe o verbo "fio", mas não o substantivo. A tradução seria "hilo". Em compensação, há a palavra "con", que é uma preposição conectiva da língua espanhola. 
Este livro procura interpretar a poesia de João Cabral de Melo Neto a partir da hipótese de que ela se constrói sob o prisma do menos. Com isso, queremos dizer que os processos de formalização de seus textos são deflagrados por uma ótica de desconfiança frente ao signo lingüístico, sempre visto como portador de um transbordamento de significado. Amputar do signo esse excesso é praticar o que denominamos a poesia do menos. Mas, para João Cabral, desvincular a palavra de uma tradição retórica não é suficiente: a desconfiança do poeta incide tanto na antiga ordem de significações do signo quanto na nova ordem em que ele o instala. Daí sua poesia freqüentemente confessar-se como um ponto de vista (histórico) sobre a linguagem, e não como um neutro espaço de onde as palavras emanariam resgatadas numa pureza original. Nosso trabalho consistirá, também, em mostrar a articulação dialética entre a palavra esvaziada do poema e o espaço cultural e social que ela incorpora, balizado igualmente pelos metros da carência e do desfalque.

Se a obra cabralina comporta essa linha de análise, é evidente que nela não se esgota. Por isso, sobre enfatizarmos 


\section{APROXIMAÇÃO ENTRE TEMPERATURAS:} JOÃO CABRAL DE MELO NETO

\section{Máquina de Comover}

VII Bienal do Mercosul (2009)

É sabida a relação do poeta João Cabral de Melo Neto (1920-1999) com as artes visuais. $\mathrm{Ou}$, com a fronteira entre a poesia e as artes visuais; ou, com as imagens. $\mathrm{Ou}$, com os artistas.

$$
\begin{aligned}
& \text { Poema } \\
& \text { _olbos_telescópios } \\
& \text { espiando _., } \\
& \text { espiando } \\
& \text { - - - - - } \\
& ---- \\
& \text { _ } \text { invisíveis. } \\
& \text { - - - _ cegos } \\
& \text { _ _ visões mecânicas. }
\end{aligned}
$$

$$
\begin{aligned}
& ------- \\
& ----- \\
& -- \text { contemplando } \\
& - \text { retrato }_{-} \cdot{ }^{77}
\end{aligned}
$$

77 Faço aqui um exercício livre de subtração de todos os termos que não se ligam diretamente à visualidade. É o primeiro poema do primeiro livro lançado por João Cabral em 1942. MELO NETO, João Cabral de. Pedra do Sono. Rio de janeiro: Ed. José Olympio, 1956, p. 143. 
Mas se por um lado o poeta constrói imagens, por outro, não as dá. Sua poesia é de sugestão. O que cria é um espaço para que o leitor as construa. Ou, constrói um espaço para que o leitor se construa. Constrói o leitor para que ele o construa.

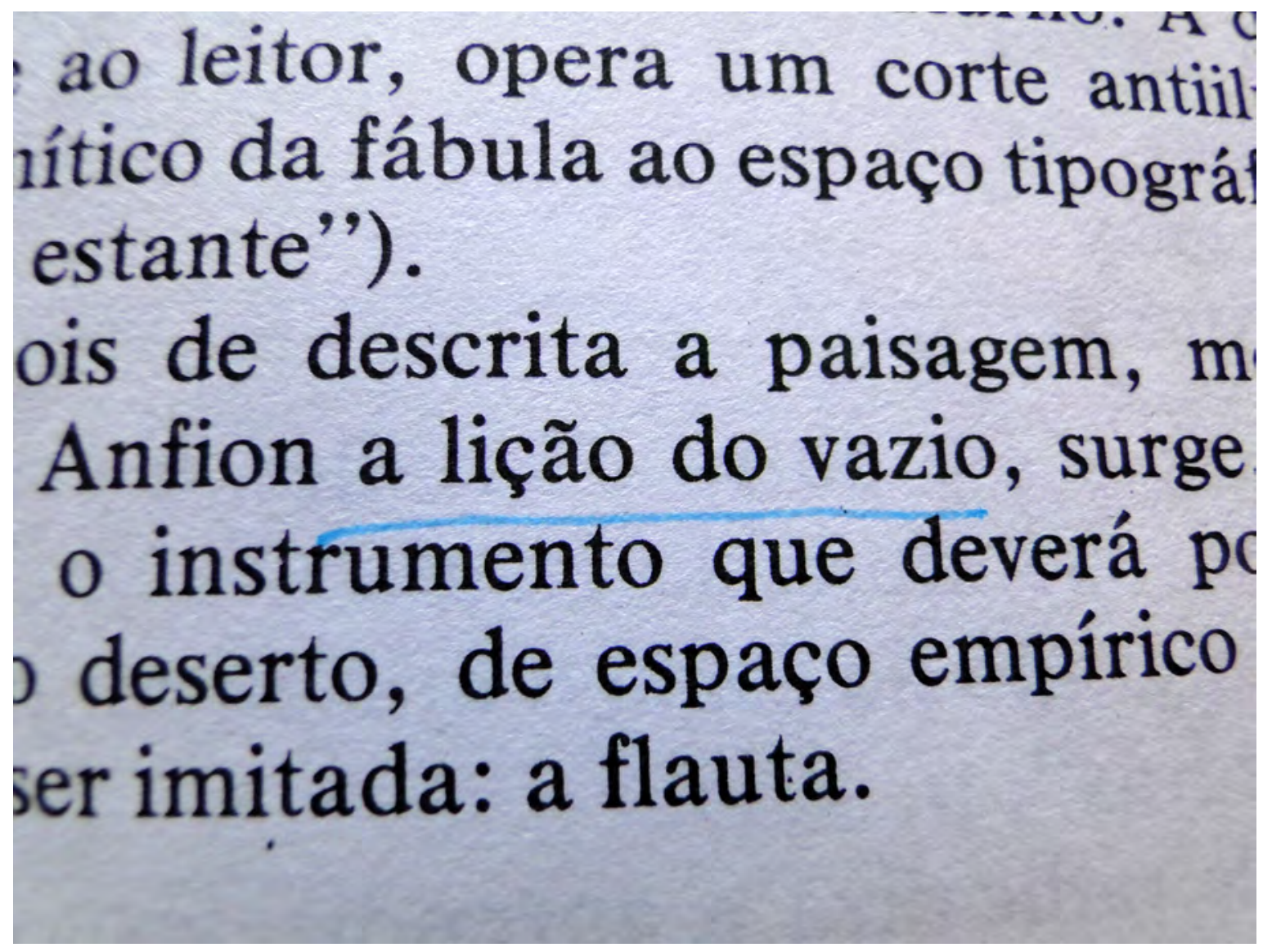

\subsection{Tradução e influência}

Transcriações, triduções, transluciferações, transfingimentos, transficcionalizações, transpoetizações, intraduções, transfusões $e$ transmutações ${ }^{78}$ podem ocorrer entre as diferentes línguas e linguagens. Interessado nas artes visuais ${ }^{79}$, João Cabral revela suas influências e realiza tais processos em poemas como Homenagem a Picasso (Melo Neto 1982: 99), quando absorve o pintor para dentro de sua poesia e vocabulário: "Não há música aparente nos violinos fechados. Apenas recortes de jornais...”. Violinos e guitarras são imagens frequentes em Picasso (1881-1973). Cabral as emudece, como também faz com a flauta no poema Fábula de Anfion: "sua flauta seca” (Melo Neto 1958: 84). O signo do jornal é igualmente compartilhado por Picasso

Foto da pág. 53 do livro João Cabral: a poesia do menos, de Antonio Carlos Secchin (1985).

78 Expressões usadas pelos Poetas Concretos - Augusto e Haroldo de Campos e Décio Pignatari - para caracterizar o ato tradutório. LAGES, Susana, 2002, p. 92.

79 "Sendo provavelmente o mais visual dos poetas brasileiros, ele começou a criar nestes livros uma "arte de ver" que é só sua, “....Sua amizade duradoura com artistas plásticos e arquitetos era consequência dessa sua procura de novas maneiras de organizar a experiência sensorial...». TAVARES, Braulio In: MELO NETO, João Cabral de. Morte e Vida Severina; e outros poemas. Rio de Janeiro: Objetiva, 2007, p.7. 


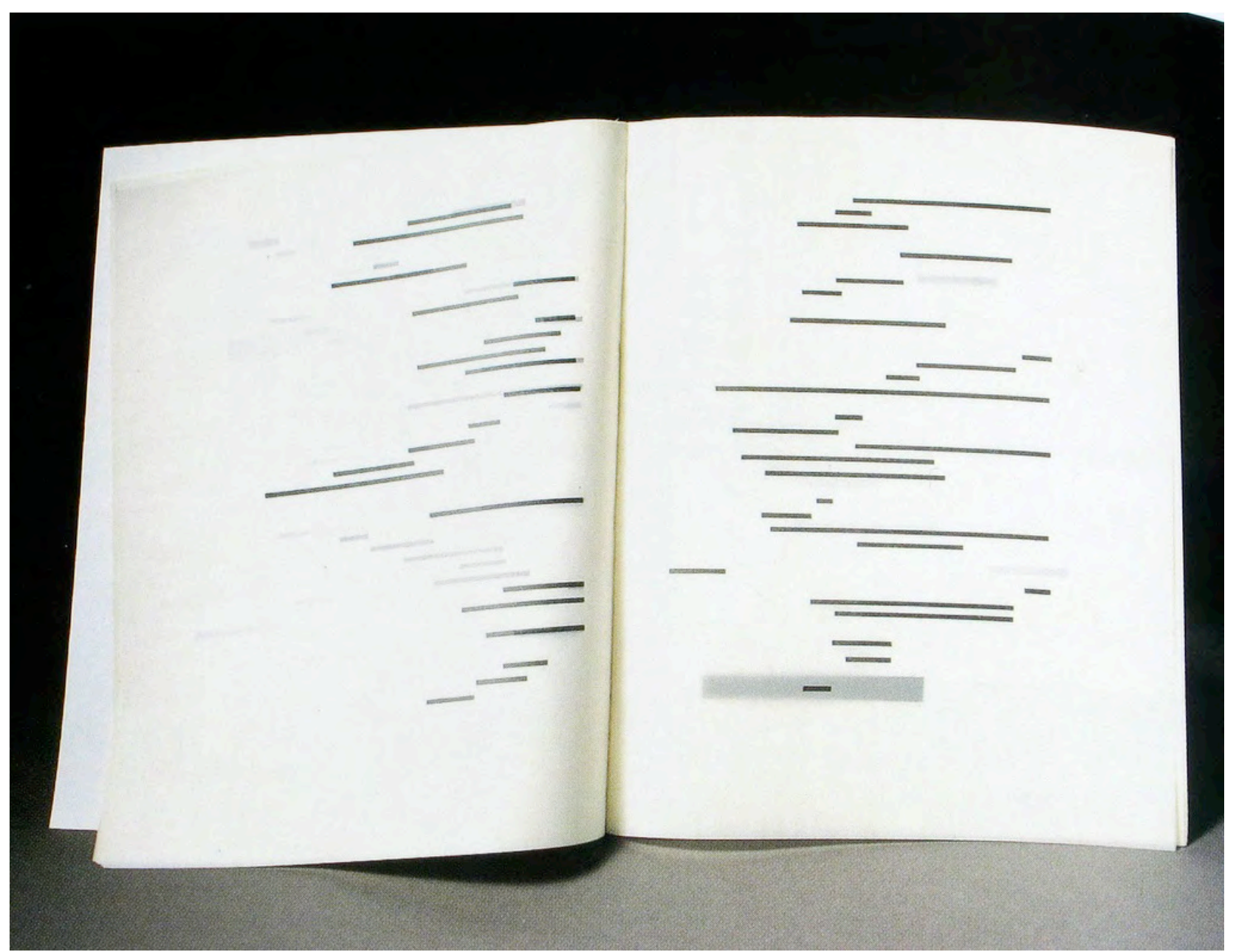

e João Cabral, ora como objeto, ora como lugar, texto ou contexto. Mais do que uma homenagem, João Cabral cria uma espécie de escrita híbrida em Homenagem a Picasso, que propõe imagens relacionadas ao pintor, ao mesmo tempo que utiliza uma poética própria de sua obra. Assim, seu poema deixa de ser um elogio para se tornar uma leitura contundente. Pela escrita, o poeta puxa a pintura para o intelecto, descolando-a da ideia de ser uma experiência predominantemente sensorial $^{80}$.

O linguista Roman Jakobson definiu as transposições entre linguangens de "traduções intersemióticas". De acordo com o artista Julio Plaza, este conceito "consiste na interpretação de um sistema de signos para outro, por exemplo, da arte verbal para a música, a dança, o cinema ou a pintura." (Plaza 1984: 15) Um exemplo é

Un Coup de Dés Jamais n'Abolira Le Hasard, 1969, Marcel Broodthaers. a leitura que o artista plástico belga Marcel Brooadthaers fez do poema Um Lance de Dados Jamais Abolirá o Acaso (1897) de Stéphane Mallarmé. O artista criou uma versão puramente gráfica, usando o layout tipográfico do poeta, mas com as palavras substituídas por barras negras.

80 Baseado em anotações de sala de aula da disciplina Estudo Analítico da Poesia de João Cabral de Melo Neto do Professor Ari Vidal: "O quadro vai para o intelectual, não é para ser sentido", maio 2009, FFLCH-USP. 
Para João Cabral de Melo Neto, o arquiteto francês Le Corbusier (1887-1965) lhe salvou do surrealismo ou, mais contundente ainda: "Nenhum poeta, nenhum crítico, nenhum filósofo exerceu sobre mim a influência que teve Le Corbusier”. Para o poeta, por muito tempo Le Corbusier significou "lucidez, claridade, construtivismo. Em resumo: o predomínio da inteligência sobre o instinto” (Athayde 1998: 133). Tal ponto de contato entre os dois caracteriza o que Cabral chamou de influência, cuja etimologia está relacionada ao vírus influenza. No entanto, se pensarmos em Cabral numa posição ativa, não a de quem é contaminado, mas a daquele que ativamente busca seus interesses na obra do outro, podemos aproximá-lo do movimento antropofágico brasileiro, que na eleição e deglutição de um outro estranho a si busca o substrato para a construção do eu.

Assim também foi com Carlos Drummond de Andrade, Joan Miró, Murilo Mendes, Joan Brosa, entre outros: são objetos de leitura forte do poeta ${ }^{81}$. Discordo portanto da palavra influência, que pressupõe passividade: ser infectado sem escolha. João Cabral é quem come: outro poeta para a sua poesia; o arquiteto para poesia; o pintor para poesia. Faz uma "aplicação radical do conceito modernista de antropofagia como estratégia particular de leitura da tradição... não é mais ‘influência’ (assimilação passiva)” (Lages 2002: 90).

Como epígrafe do seu livro O Engenheiro (1942), João Cabral se apropria de uma expressão que Le Corbusier usa para caracterizar uma pintura: ...machine à émonvoir.... A expressão foi traduzida para o português por “máquina de comover”. Associar a poesia a uma máquina faz sentido no contexto histórico de Cabral e Le Corbusier, o do modernismo e sua idéia otimista de que a precisão maquínica e a racionalidade poderiam resolver problemas sociais. Se a tradução para o português gera a expressão acima, poderia também particularizá-la e dar um salto além, propondo uma transposição mais específica para o universo visual cabralino:

máquina de como_ver

81 No livro Poesia Crítica, João Cabral reúne numerosos poemas nos quais “o autor tomou como assunto a criação poética e a obra ou personalidade de criadores poetas ou não.” MELO NETO, João Cabral de. 1982. 
Comover é causar comoção, ou emoção, desaquietar e colocar em movimento. $\mathrm{Na}$ poesia, o leitor seria o receptor e aquele que sofre o estímulo que causa a comoção, provocada pelo poema, o causador. Quando corta-se a comoção, como/ver, o que se tem é uma maneira de ver, quase como um método. Passa-se a um ambiente pedagógico, no qual o poema dá uma lição ${ }^{82}$ : a de ver. Uma máquina de ensinar a ver. Em Cabral, é uma imagem sugerida. Para Antonio Carlos Secchin, é justamente a partir de O Engenheiro (Melo Neto 1956: 114) que a poesia de João Cabral constrói a passagem entre o “comover” e o “como/ver" ${ }^{83}$. Ensina-se a ver pois o olhar não está dado; é produzido pela cultura, pelos seus aparatos: telescópios, óculos e lentes, objetos frequentes em sua poesia. Olhar desnaturalizado. A visão é construída, engenhada.

\subsection{Um exercício de transcriação de $O$ Engenheiro para um filme}

Para o trabalho final da disciplina Estudo Analítico da Poesia de João Cabral de Melo Neto do Professor Ari Vidal (FFLCH-USP, 2009), cursada durante o doutorado, elegi como ponto de partida a epígrafe do livro analisada acima: “...machine à émouvoir...", ou "máquina de comover". Parti assim de uma exterioridade, alguém que foi escolhido por João Cabral (a epígrafe está na borda do livro, na fronteira entre o dentro e o fora). O suporte inicial para a ação foram folhas de jornal. Delas escolhi uma palavra aleatoriamente para recortar uma letra. Realizei a operação dezesseis vezes, uma para cada letra da expressão eleita: máquina de comover.

82 Para uma análise da relação da poesia de João Cabral de Melo Neto com o seu aspecto educativo, ver: BARBOSA, João Alexandre. João Cabral ou a educação pela poesia. Capturado em 15 set. 2009. Online. Disponível em: < http://www.apropucsp.org.br/revista/rcc01_r07.htm>

83 "Depura-se o poeta para fazer do poema a máquina de comover de que fala a epígrafe da obra (Le Corbusier). João Cabral experimentará, no livro seguinte, mover-se com a mineralização do espaço poético, num nível conceitual germinado em vários textos de $\mathrm{O}$ Engenheiro, e que conferirá ao poema, antes de tudo, o estatuto de máquina de como/ver o real.” SECCHIN, Antonio Carlos. João Cabral: a poesia do menos. São Paulo: Ed. Duas Cidades, 1985. 


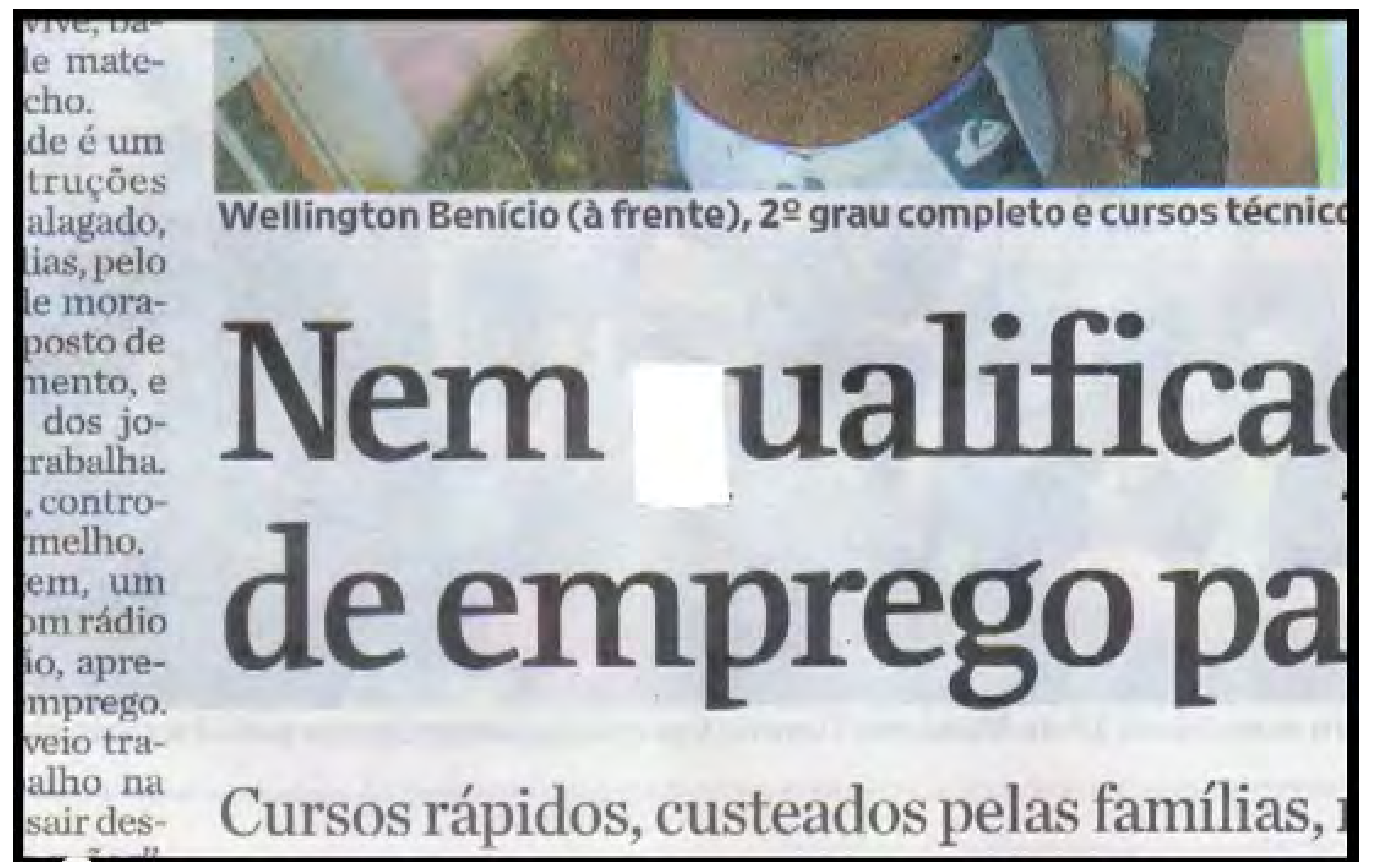

Os pedaços de jornal com as letras faltantes foram então digitalizados e organizados em um programa de edição de filme cinematográfico. As palavras foram montadas em uma sequência fílmica, uma a uma, de modo a escreverem (pela ausência) a expressão. Os vazios de cada uma foram alinhados para que sempre fossem centrais na imagem, ou seja, sempre havia um ponto fixo nas projeções onde não havia imagem, somente luz. $\mathrm{Na}$ edição, a sequência de palavras que formava a expressão era repetida quatro vezes: a primeira, mais veloz, evidenciava o vazio, mas não deixava ler o seu contexto; até a última, mais lenta, que permitia ler a letra faltante e o seu contexto $^{84}$.

Still do filme Máquina de Comover (2009).

No still do filme acima, o recorte é um lugar de ausência de qualquer texto ou imagem. É o ponto esvaziado da imagem que revela o papel branco, despido e sem ornamentos. Quando projetado em filme diretamente na parede, o mesmo ocorre. O espaço vazio é concreto e cimento ${ }^{85}$. É no encontro com o real da folha em branco e do cimento e concreto que se torna possível construir, engenhar alguma imagem, a partir do seu contexto. Ou seja, o vazio que fica não é estático, é vácuo que convoca a um olhar ativo. É o leitor que, provocado pela ausência, trabalha e edifica o enunciado em sua mente:

84 Online. Disponível em: <http://youtu.be/eSvRviuGlUE>.

85 Em A Fabula de Anfion, Cabral propõe uma "lição do vazio" para chegar na secura limpa do deserto, como um lugar de depuração. A partir dali, e do acaso, propõe uma ressignificação deste vazio. SECCHIN, Antonio Carlos, 1985, p.51. 


\section{É um}

\section{engenho de}

\section{como $\operatorname{ver}^{86}$}

\subsection{Aproximando temperaturas}

Diferente das hobras com relações mais diretas entre original e tradução descritas até agora - Felix, Área semicrítica e Inserções Revista -, minha aproximação da obra de João Cabral de Melo Neto se revela numa certa temperatura inspirada no autor. O que define o clima não é um objeto, ou método, mas uma certa ambiência - cuja visibilidade por vezes não é clara. Calor ou frio não são propriedades visíveis. São sensações. O que vemos é sua ação determinante nos comportamentos e na forma como modela uma pai-

86 A imagem do engenho é recorrente em Cabral, como parte da sua origem e motivo regional do nordeste brasileiro: "Quando fui para Recife, não gostava da cidade, queria voltar. Meu sonho de felicidade era o engenho. Sou um homem rural, compreende?”. Entrevista em Perfis \& Entrevistas - Escritores, artistas e cientistas, p.16 Capturado em 15 ago. 2011. Online. Disponível em: <http://www.livrariacultura.com.br / imagem/capitulo/3159329.pdf>. 
sagem. Assim, a pesquisa sobre João Cabral, mais do que ter gerado novas obras, gerou um certo ambiente, uma zona a partir da qual pensei novas hobras - ou reli algumas já existentes. Tais hobras são portanto indícios de que estamos num terreno cabralino, na

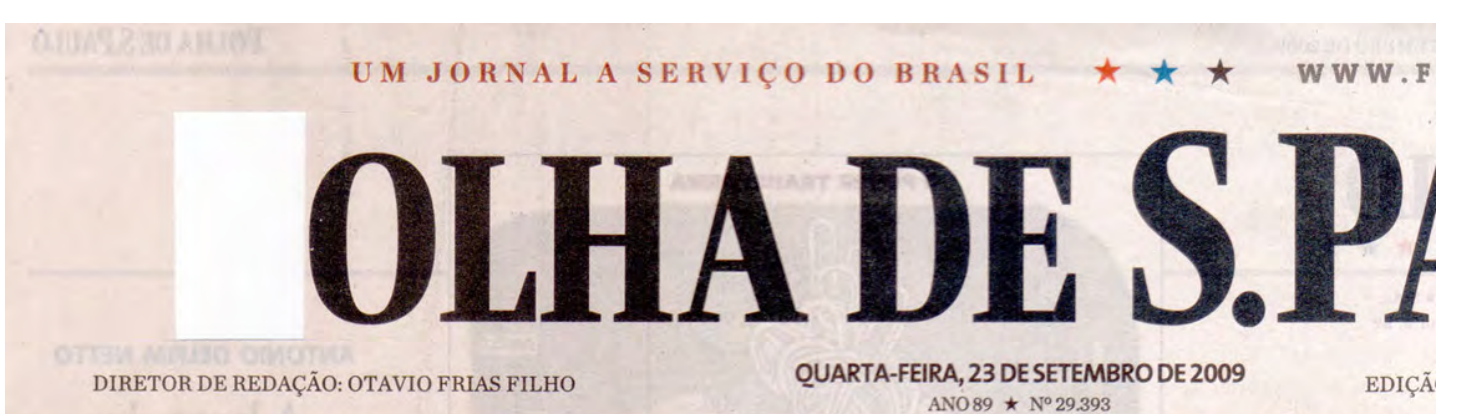

\section{Honduras sitia Embaixad}

Governo golpista corta água e luz de casa onde Zelaya se abrigou; presidente CLóvis ROSSI

Brasil foi atacado por golpistas e não tem como reagir

Ao cortar água, telefone e
luz da embaixada, o governo luz da embaixada, o governo rio brasileiro. E o Brasil não tem como reagir. Pelo mấ nos não fisicamente É maginável mandar tropas: Resta o recurso à legislacão internacional, demorado demais e que não tem comovido os golpistas. Pá. A12

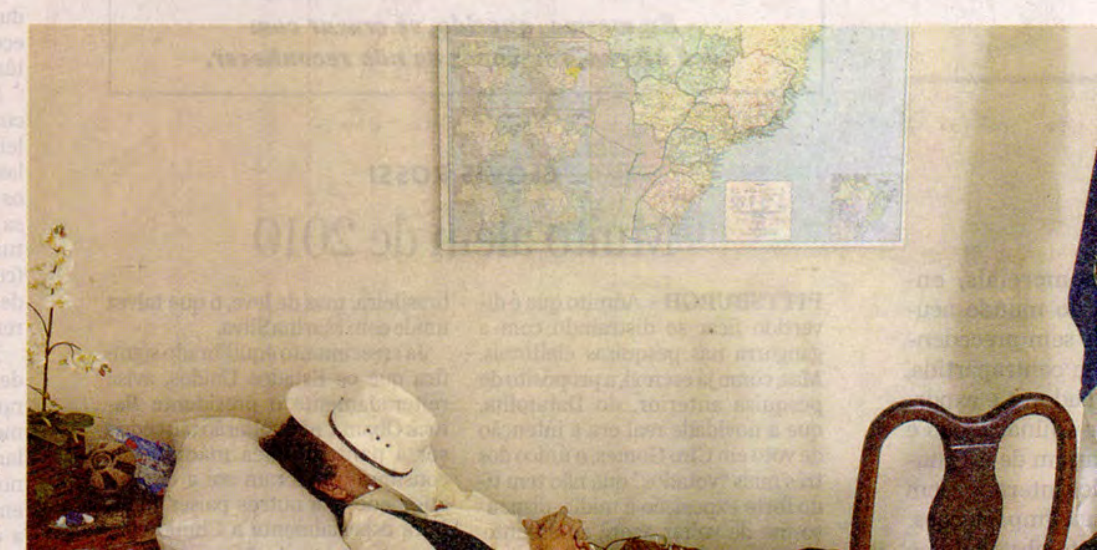

Detalhe da imagem da capa da folha de São Paulo. sua vizinhança, ou raspando-o. No mesmo ano em que realizei a pesquisa sobre João Cabral de Melo Neto, fui convidado pelo artista-curador Erick Beltran a desenvolver uma série de intervenções para a $7^{\mathrm{a}}$ Bienal do Mercosul (2009). A ideia da sua curadoria era apropriar-se dos meios de divulgação da Bienal, geralmente utilizados para publicidade, como mais um suporte possível para os artistas. Os meios eram: cartazes, página de jornal e outdoors.

Página de jornal: A operação consistiu na extração da letra "F" da capa do jornal Folha de São Paulo do dia 23 de setembro de 2009. A notícia principal do dia foi o exílio do presidente hondurenho Zelaya na Embaixada Brasileira de seu país. A imagem gerada era para ter sido reproduzida em uma folha inteira da Zero Hora, principal jornal da cidade de Porto Alegre, onde acontecia a Bienal ${ }^{87}$.

87 Embora projetada e aprovada pela curadoria da $7^{a}$ Bienal do Mercosul, a intervenção planejada na folha de jornal não aconteceu. 


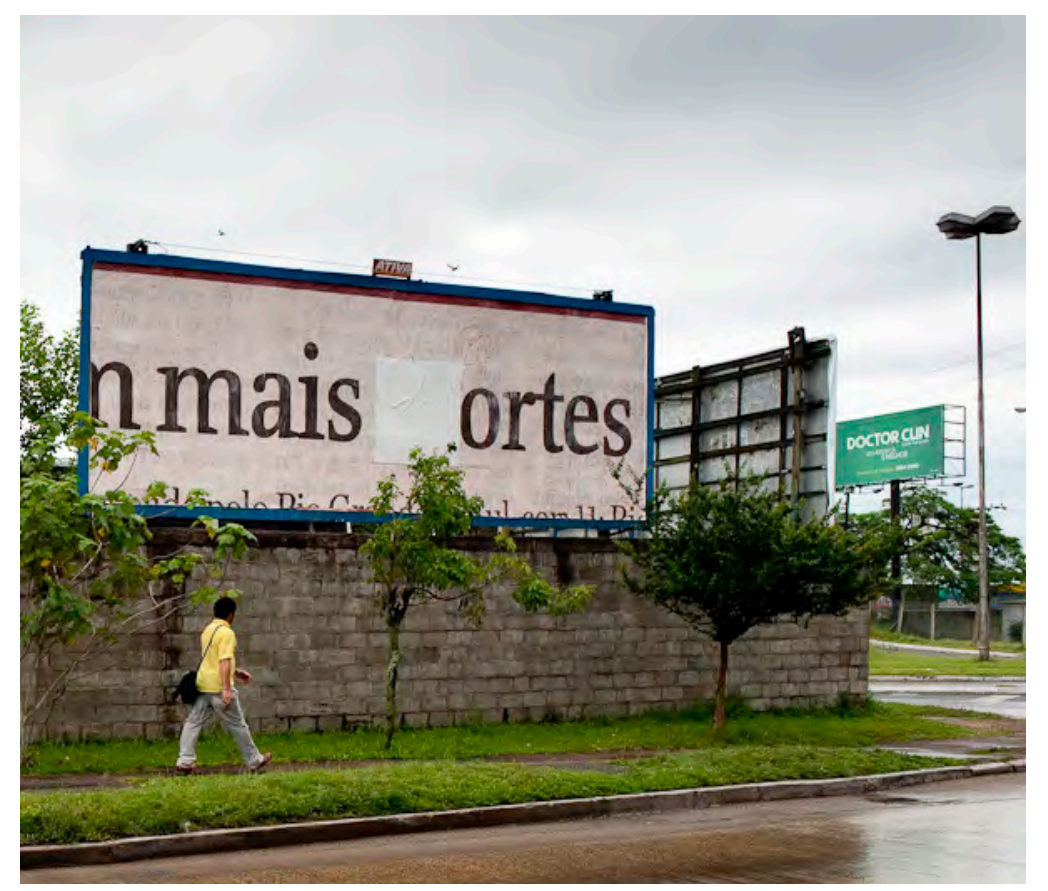

Outdoors: Outra das operações deu-se em um conjunto de outdoors espalhados pela cidade. Neles, constava um recorte de jornal, cujo texto sofria a mesma interferência - a subtração de uma letra.
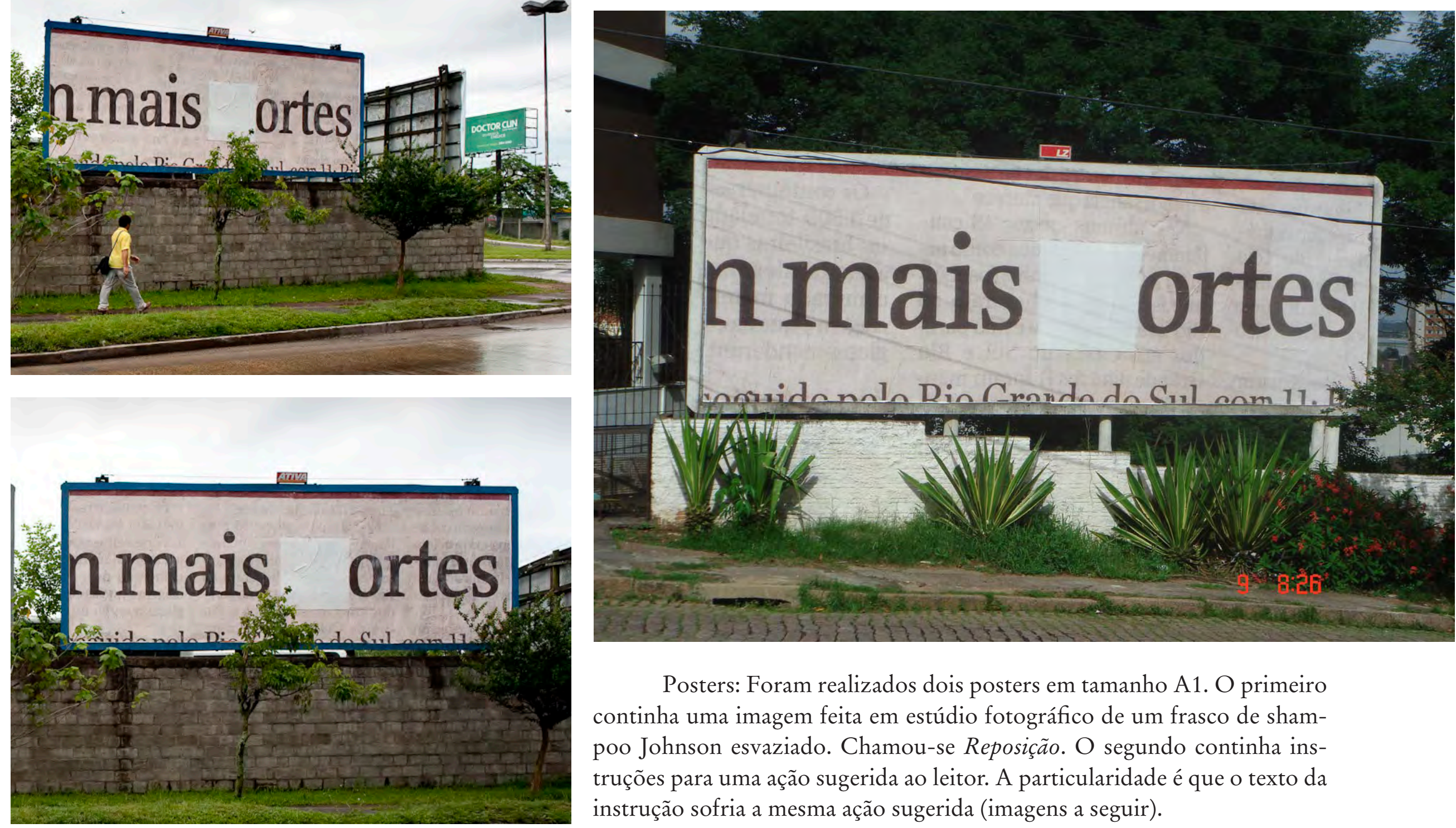

Posters: Foram realizados dois posters em tamanho A1. O primeiro continha uma imagem feita em estúdio fotográfico de um frasco de shampoo Johnson esvaziado. Chamou-se Reposição. O segundo continha instruções para uma ação sugerida ao leitor. A particularidade é que o texto da instrução sofria a mesma ação sugerida (imagens a seguir). 


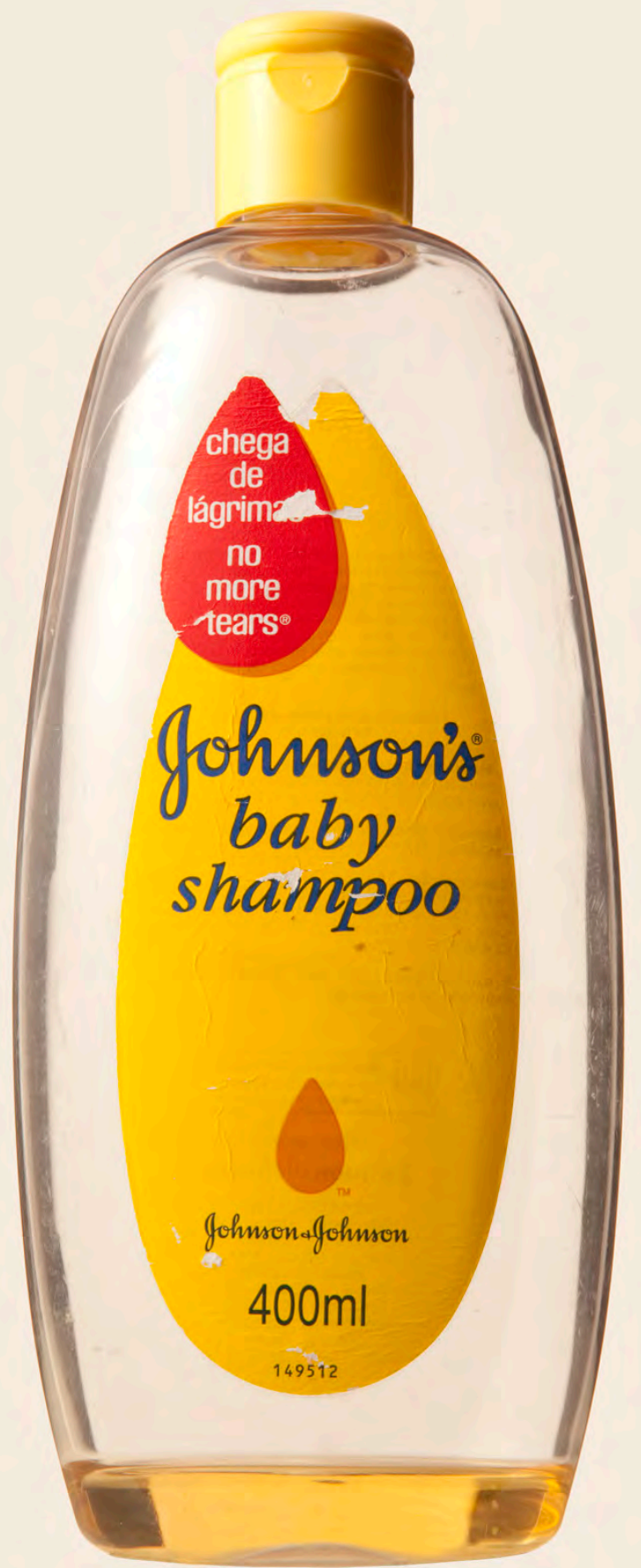


1- Escolha uma palavra no jornal. Escolha uma letra desta palavra. Qualquer uma. Recorte-a e retire-a da palavra. Descarte a letra. Olhe de novo para a pal_vra. 
A subtração, como forma de construção, permeia toda a obra de João Cabral de Melo Neto, o que lhe confere um clima seco, cortante e afiado. É esse ambiente que busco reproduzir nessas hobras e também no texto econômico que as descreve. Em palestra sobre a obra que apresentou na Bienal de Veneza de 2007, o artista brasileiro Iran do Espírito Santo deteve-se a uma descrição formal das obras que apresentou, evitando todo comentário interpretativo ou autobiográfico. O aspecto enxuto da fala do autor me chamou a atenção na época, até que alguns dias depois da palestra, tive um insight sobre uma das obras que o artista apresentara. Hoje pergunto-me se o relativo ocultamento da posição do artista em relação a sua própria obra não teria sido estratégico e contribuído para que eu pudesse ter, dias depois, uma experiência singular de produção de sentido. Estampido. O rebaixamento da voz do artista, no sentido de não prover uma leitura oficial da sua própria obra, revelou-se, naquele momento, como um ato de generosidade e confiança na recepção. Uma fala pela subtração. 
it To transform the material. Once again, it was a way to use the same material that I was so tired of, but in an absolutely new way. Although I worked with plastic bags almost twenty years before, in the Nomes series and the museum bags series, I could deal with this material again but in a new way. I'm transgressing my own work. If in the first moment the piece is called Nomes, in the second moment all names are removed. I took the names away, but I left the handles. You can carry them, mentally. Although the bags are an old material that I've already used and established, it's through that material that I can still keep thinking art. When I say these works lead me to Albers and Klee, Fontana and Nauman, I am thinking art. It's my only goal. 


\section{O LEITOR SITUADO E A INSTABILIDADE DO ORIGINAL: IAN HAMILTON FINLAY}

Concreto, (2010)

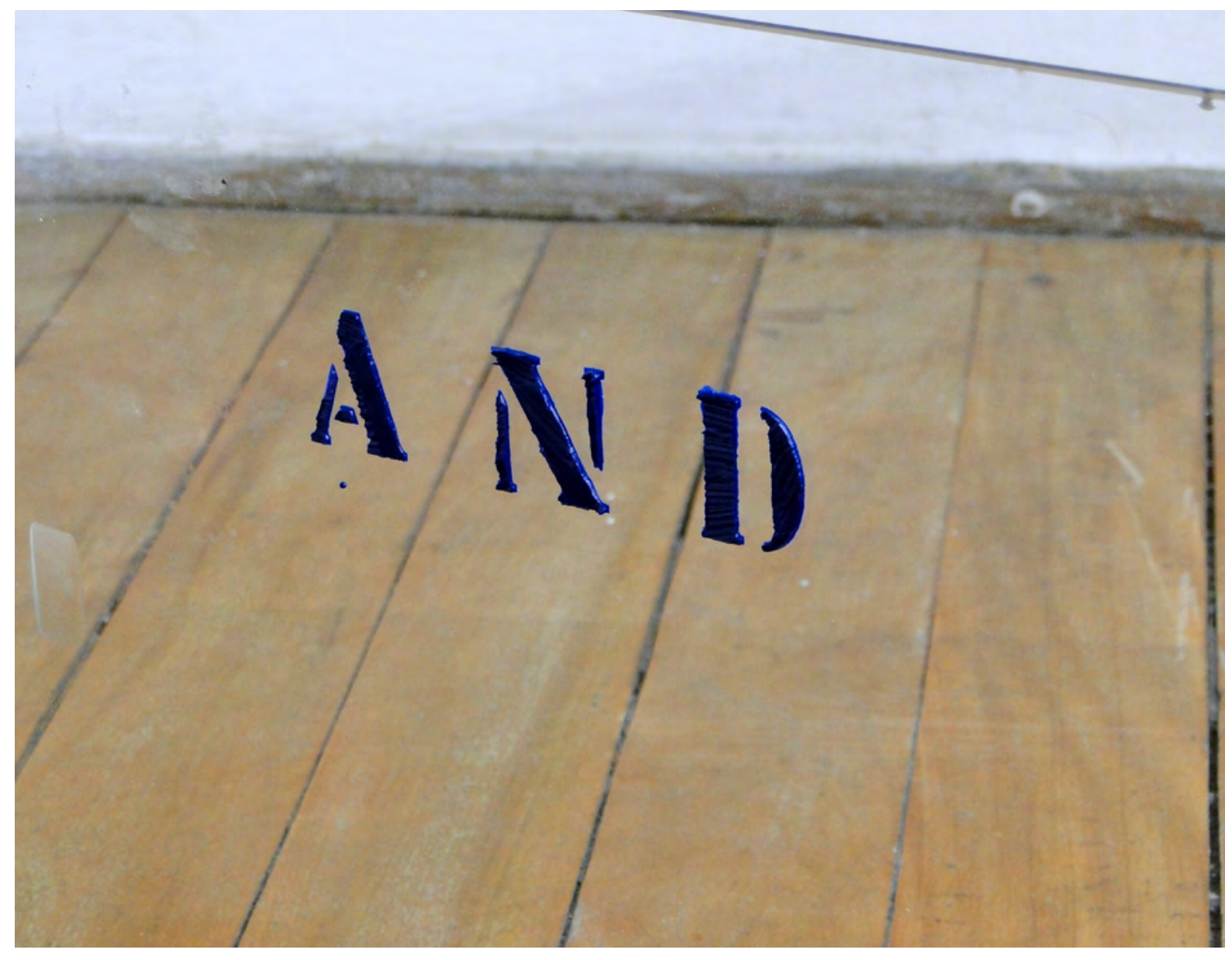

A bobra Concreto nunca foi realizada integralmente. Existiu apenas enquanto projeto, na forma de texto, protótipos e imagens. Foi idealizada para concorrer ao edital do XIII Festival da Cultura Ingle- 
sa ${ }^{88}$, em São Paulo (2010), não tendo sido selecionada. Para dizer que uma obra existe, é necessário que seu ciclo se complete ao ganhar visibilidade pública. Sem a figura do receptor bem construída, o autor impera perigosamente. Feito o alerta, posso defender os motivos para incluí-la na tese. O mais explícito diz respeito à singularidade com a qual seu pensamento aborda e adensa os temas discutidos. Além disso, prover-lhe um leitor irá conferir-lhe um estado mais próximo da existência, ainda que esteja vestida aqui com uma roupagem que não é a idealizada. De toda forma, interessa pensar o lugar do presente texto igualmente na qualidade de espaço ativo e não apenas na condição documental de algo que já existiu. Sobre a decisão de incluir trabalhos não realizados na constelação da tese de doutorado, escreve a artista Renata Lucas:

Optei por uma narrativa cronológica dos trabalhos produzidos por me parecer a mais apropriada, voltando oportunamente a experiências passadas, perpassando inclusive projetos não executados, vez ou outra, para mostrar que além do que foi realizado há conexões que se mantiveram irresolutas, e permanecem operantes, como sonhos maldormidos, imprimindo sua força interrogativa ao trabalho. Acredito em força imaginativa, pensamentos invisíveis operando no trabalho. Forças que se desviaram ou se adiaram num projeto que não veio a ser, dando impulso a vozes que ainda não foram bem ouvidas e talvez jamais se formalizem completamente. $\mathrm{Na}$ verdade, creio que um trabalho de arte nunca se formaliza completamente. $\mathrm{O}$ artista lida sempre com o invisível mais do que com o visível. Um amigo certa vez me disse que o problema das escolhas é que os caminhos rejeitados continuam a existir, e podemos olhá-los de longe como uma possibilidade já não viável, embora presente. É uma constatação melancólica para o amor, mas fortuita para a arte. Enquanto houver a chave, portas se apresentarão, e o trabalho não estará jamais concluído (Lucas 2008: 15).

O projeto propunha uma transcriação da obra That which joins and that which

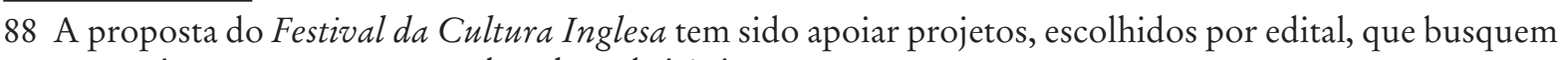
uma aproximação com aspectos da cultura britânica. 


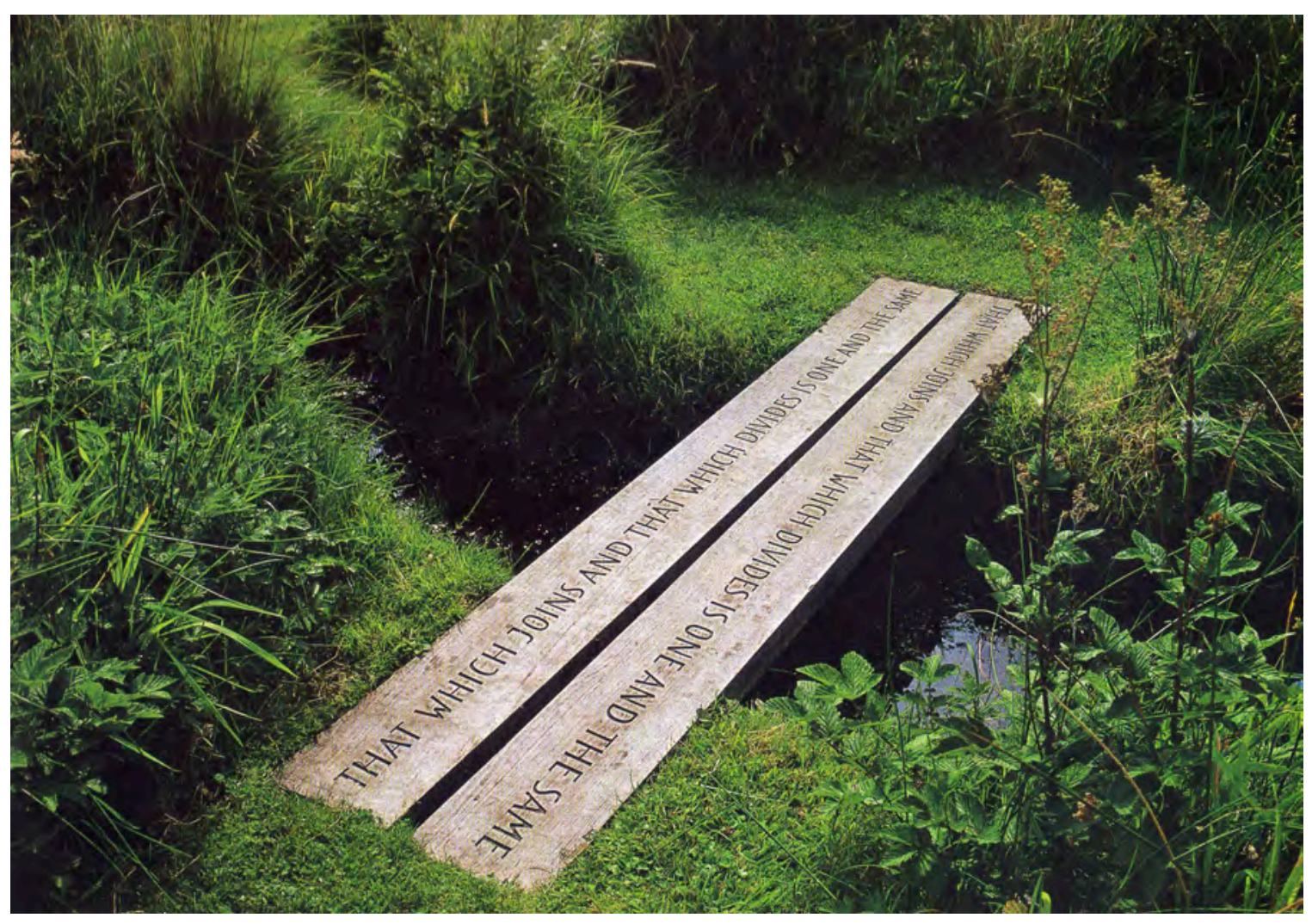

divides is one and the same, do artista escocês Ian Hamilton Finlay (1925 - 2006). A obra também cumpre a função de ponte e está instalada sobre um riacho em Little Esparta, um sítio nos arredores de Edimburgo, Escócia. Foi onde o artista viveu os últimos 40 anos de sua vida, acompanhado de sua mulher e colaboradora Sue Finlay. O lugar abriga grande parte da sua produção escultórica, integrada a um imenso jardim que lhe serve de contexto e motivo de reflexão.

Tendo iniciado sua carreira como poeta e escritor, foi a partir da primeira publicação de poemas concretos (Rapel, 1963) que Finlay ganhou reconhecimento. Foi assumidamente influenciado pelos poetas concretos brasileiros - Augusto e Haroldo de Campos e Décio Pignatari, criadores do movimento e do próprio

Foto da instalação de Ian Hamilton Finlay composta por duas tábuas robustas de madeira com uma mesma frase entalhada e repetida em sentidos opostos. termo Poesia Concreta na década de 1950 -, cuja reflexão sobre a estruturação do texto no seu suporte concreto reverbera em toda a obra do artista escocês. Finlay não limitou, no entanto, a sua pesquisa à espacialização da palavra no papel, mas a expandiu e populou objetos e esculturas, sempre muito atentos ao seu local de disposição. A preocupação relacional fica explícita quando o artista reflete sobre o local onde o seu pensar se instalava:

Parecia óbvio para mim que não poderia haver um poema-de-uma-palavra em uma página, já que qualquer trabalho precisa estabelecer relações; igualmente, poder-se-ia conceber um poema- 

poema. ${ }^{89}$

De acordo com o crítico John Dixon Hunt, muito da poesia de Finlay opera a partir de uma economia verbal, alinhada à ambição da poesia concreta brasileira de eliminar grande parte do "entulho sentimental e discursivo" do poema. A ideia do "poema-de-uma-palavra” ecoa portanto este impulso sintético, de uma energia concentrada, ao mesmo tempo em que busca um relacionamento intensivo com o seu entorno, claramente visível nas suas obras de jardim (Hunt 2008: 23).

O texto em inglês entalhado nos travessões de madeira que estruturam a ponte, That which joins and that which divides is one and the same, é mais diretamente traduzido para o português como: Aquilo que une e aquilo que separa é um e o mesmo ${ }^{90}$. A versão iguala o número de palavras, mantendo o significado do original e uma simetria estrutural. Poderia caracterizar tal tradução para o português como transparente ${ }^{91}$, no sentido de dar a ver com clareza o conteúdo da frase de Finlay, transportando o significado de uma língua para outra sem danos ou dificuldades aparentes. No entanto, se a versão acima dá completa visibilidade ao sentido mais imediato do original, torna o ato da passagem de uma língua para outra um movimento invisível. Em prol do conteúdo a ser transposto do inglês, o ato tradutório é apagado e rebaixado enquanto um "problematizador de linguagens" "92. Estamos diante de uma “tradução servil” (Lages 2002: 79), a qual

89 No original, em inglês: It seemed obvious to me that one could not have a literally one-word poem on the page, since any work must contain relationship; equally one could (conceivably) have a one-word poem in a garden, if the surroundings were conceived as part of the poem. HUNT, John Dixon. Nature over again: the garden of Ian Hamilton Finlay. Londres: Ed. Reaktion, 2008, p.23 (tradução minha).

90 Tradução minha.

91 Sobre a ideia de transparência e opacidade no ato tradutório, ver MAHARAJ, Sarat. Perfidious Fidelity: The untranslatability of the other In: CAMPBELL, Sarah; TAWADROS, Gilane (ed.). Annotations 6: Stuart Hall and Sarat Maharaj: Modernity and Difference.. Londres: Ed. Institute of International Visual Arts, 2001, pp. 28-35.

92 GALVÃO, Edilamar In: NUNES, Sandra Regina Chaves (org.). Estranhas Travessias. Osasco: Ed. EDIFIEO, 2004, p. 59-63. 
T H E

\section{J 0 I N S}

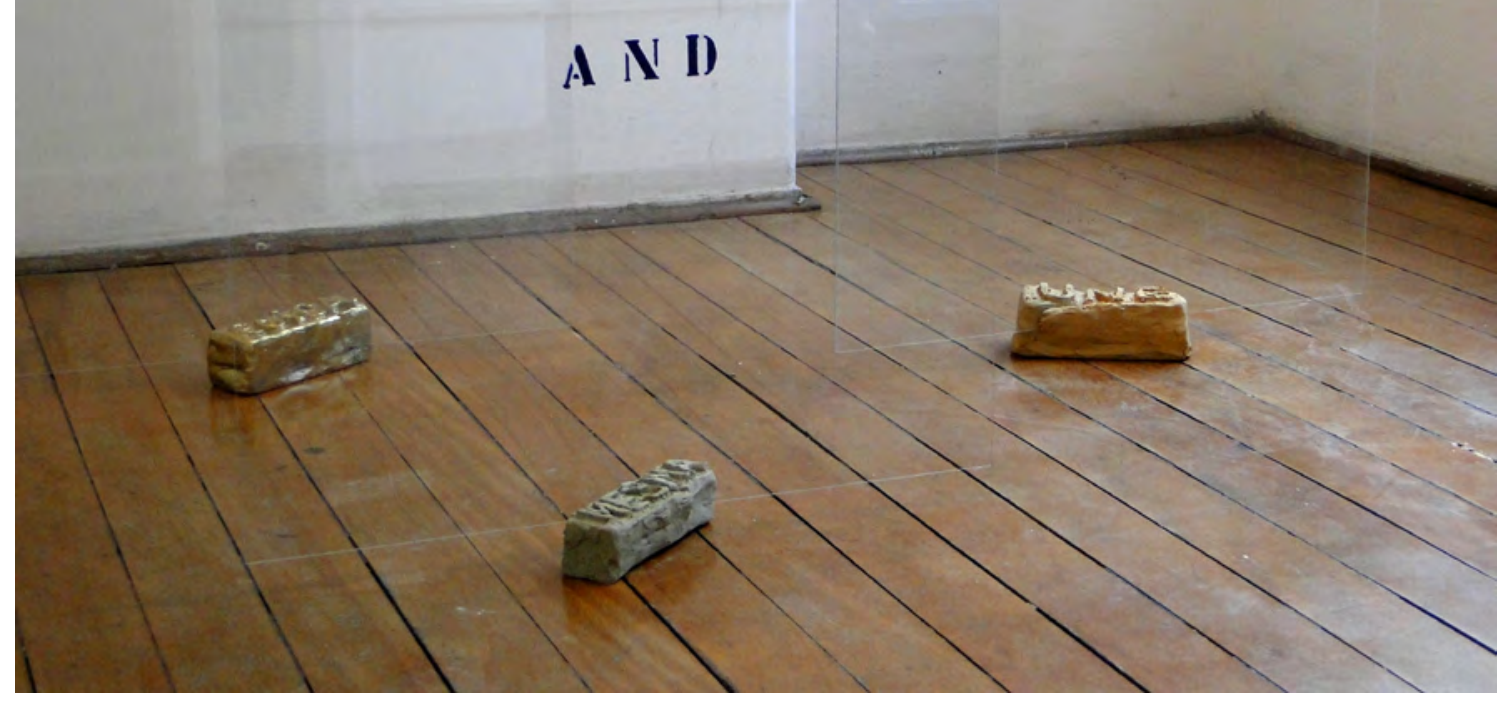

opera a partir da percepção mais vulgar do ato tradutório. De acordo com Sarat Maharaj:

No dia-a-dia, vemos a tradução como a tarefa de passar, imperceptivelmente, de uma língua para a outra, de maneira semelhante a sobrepor lâminas de vidro uma em cima da outra, uma questão de mera transparência. ${ }^{93}$

A noção de tradução implicada na hobra Concreto distanciou-se de uma condição submissa. O que estava em jogo era uma conexão com as ideias de "transcriação e transculturação" contidas na reflexão sobre tradução dos poetas concretos brasileiros. ${ }^{94}$ Além disso, é importante lembrar que o original a partir do qual propus a tradução não é apenas texto, mas um híbrido palavra-objeto, uma transição entre duas margens, feita de matéria opaca e pesada, que reivindica presença e visibilidade em sua posição de passagem.

Protótipos instalados no estúdio.

A versão para o português que propus para a parcela de texto da obra de Finlay foi: Aquilo que une e aquilo que separa é uma mesma coisa só. A não-literalidade na

93 No original, em inglês: In everyday terms, we see translation as the business of imperceptibly passing through from one language to another, not unlike stacking panes of glass one on top of another, a matter of sheer transparency. MAHARAJ, Sarat. Perfidious Fidelity: The untranslatability of the other In: CAMPBELL, Sarah; TAWADROS, Gilane (ed.). Annotations 6: Stuart Hall and Sarat Maharaj: Modernity and Difference. Londres: Ed. Institute of International Visual Arts, 2001, p. 26.

94 De acordo com o trecho: "Tradução como transcriação e transculturação, já que não é só o texto, mas a série cultural (o 'extra-texto' de Lotman) se transtextualizam no imbricar-se subitâneo de tempos e espaços literários diversos” In: CAMPOS, Haroldo. A operação do Texto. São Paulo: Ed. Perspectiva, 1976, p. 10. 
tradução - que ocorre no segundo momento da frase - se deu em função da escolha por realizar uma versão opaca da expressão one and the same. Ao invés de utilizar "um e o mesmo", que guardaria uma relação simétrica e "correta" com o original, optei por criar uma estrutura híbrida a partir da sobreposição de duas outras com significado similar: "a mesma coisa” e "uma coisa só”. O resultado foi uma terminação esdrúxula e incomum: "uma mesma coisa só”.

A frase original, assim como a transcriação, seria usada em uma instalação feita de vidro transparente, tinta óleo e bronze fundido. As doze palavras de cada frase seriam então tratadas de modo isolado. Os termos em inglês, pintados com tinta óleo em lâminas de vidro individuais. Os em português, fundidos em tijolos de bronze que serviriam então de base para apoiar as folhas de vidro. $\mathrm{O}$ encaixe entre as duas estruturas aconteceria de forma que a lâmina cortasse e atravessasse a base parcialmente, dando a impressão de riscar a palavra forjada em metal.

Houvesse optado pela tradução mais direta, os pares de palavras se organizariam da seguinte maneira:

\begin{tabular}{|c|c|c|c|c|c|c|c|c|c|c|c|}
\hline THAT & WHICH & JOINS & AND & THAT & WHICH & DIVIDES & IS & ONE & AND & THE & SAME \\
\hline AQUILO & QUE & UNE & E & AQUILO & QUE & SEPARA & É & UM & E & O & MESMO \\
\hline
\end{tabular}

Na versão proposta, a combinação é:

\begin{tabular}{|c|c|c|c|c|c|c|c|c|c|c|c|}
\hline THAT & WHICH & JOINS & AND & THAT & WHICH & DIVIDES & IS & ONE & AND & THE & SAME \\
\hline AQUILO & QUE & UNE & E & AQUILO & QUE & SEPARA & É & UMA & MESMA & COISA & SÓ \\
\hline
\end{tabular}

Aqui, o encaixe natural na primeira parte da frase - explícito em pares como “joins" e "une" -, é comprometido na segunda por desencontros que geram associações inusitadas como "the" e "coisa". 


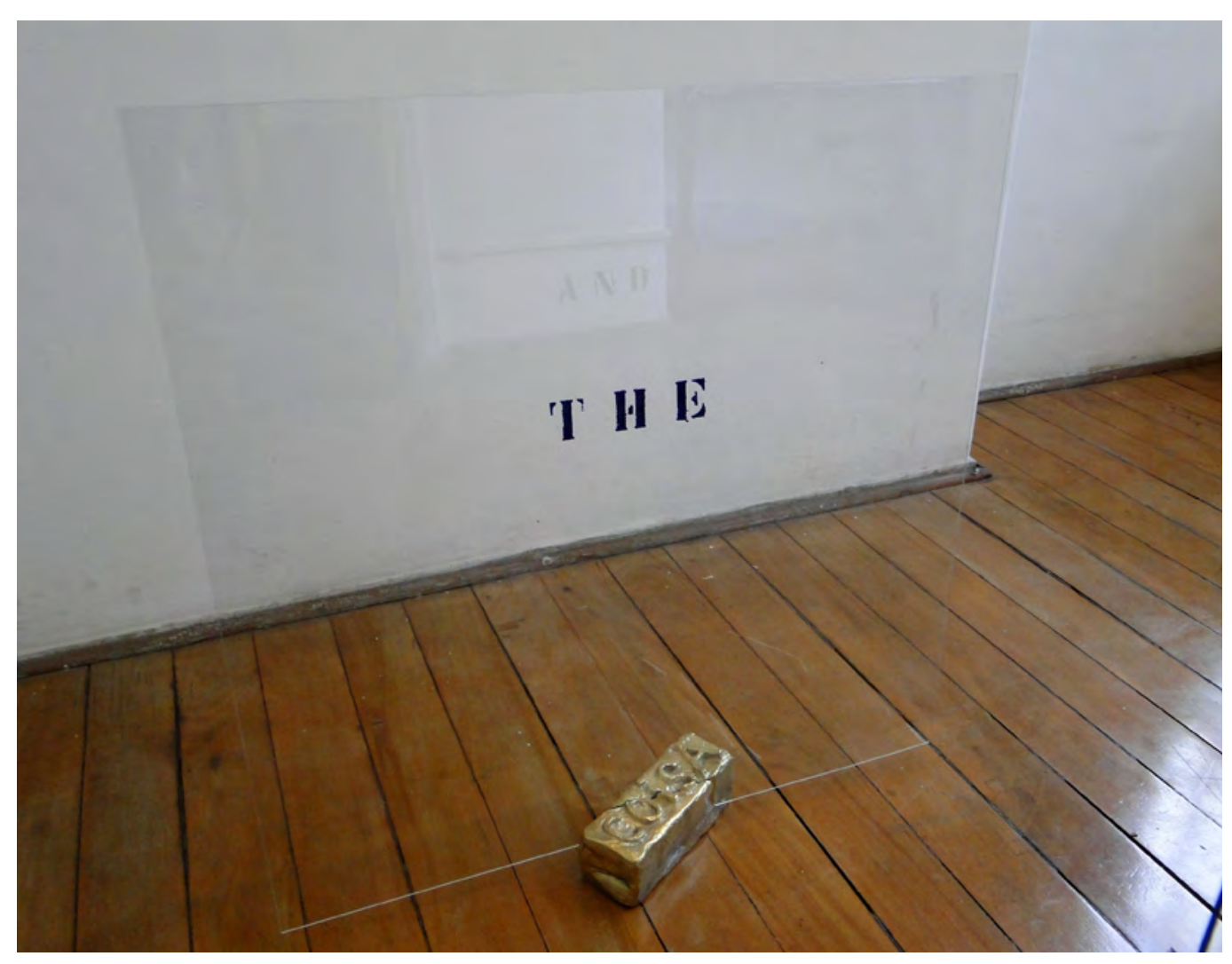

\subsection{Matéria Referencial}

O caráter aforismático do texto de Finlay, assim como a escolha do lugar onde a obra está situada - sobre o curso de um riacho - produzem ecos do filósofo pré-socrático Heráclito ${ }^{95}$. Os aforismos do pensador grego possuem uma qualidade frequentemente desconcertante. Muitos operam a partir de curtos-circuitos nas palavras e sentidos que os formam, constituindo sistemas de significados que são rebatidos e multiplicados entre si e conferindo-lhes uma característica autorremissiva. Em um exemplo muito próximo ao texto de Finlay: "O caminho para o alto e o caminho para baixo são um e o mesmo" ${ }^{\prime \prime}$.

A ideia de remissão também está presente nas constantes referências feitas por Finlay a outros autores. Perseguir pistas nas suas obras é um exercício sugerido frequentemente pelo próprio artista, já que grande parte de sua obra incorpora citações, ou o que o crítico de arte Michael Archer chama de "matéria referencial" (reference matter). Para o crítico, o aspecto referencialista da obra de Finlay sugere diversas compreensões:

A matéria referencial, que é integral à coerência formal e matérica da obra, tanto oferece indicações das fontes utilizadas

\footnotetext{
95 Jessie Sheeler faz a associação dessa obra com Heráclito no livro Little Sparta: the garden of Ian Hamilton Finlay. Escócia: Ed. Frances Lincoln, 2003, p. 33.

96 Frase de Heráclito. Online. Disponível em: <http//:www.casadosino.com.br/divulgacao/ biblioteca/ pre_socraticos os_pensadores.pdf (p.6).
} 


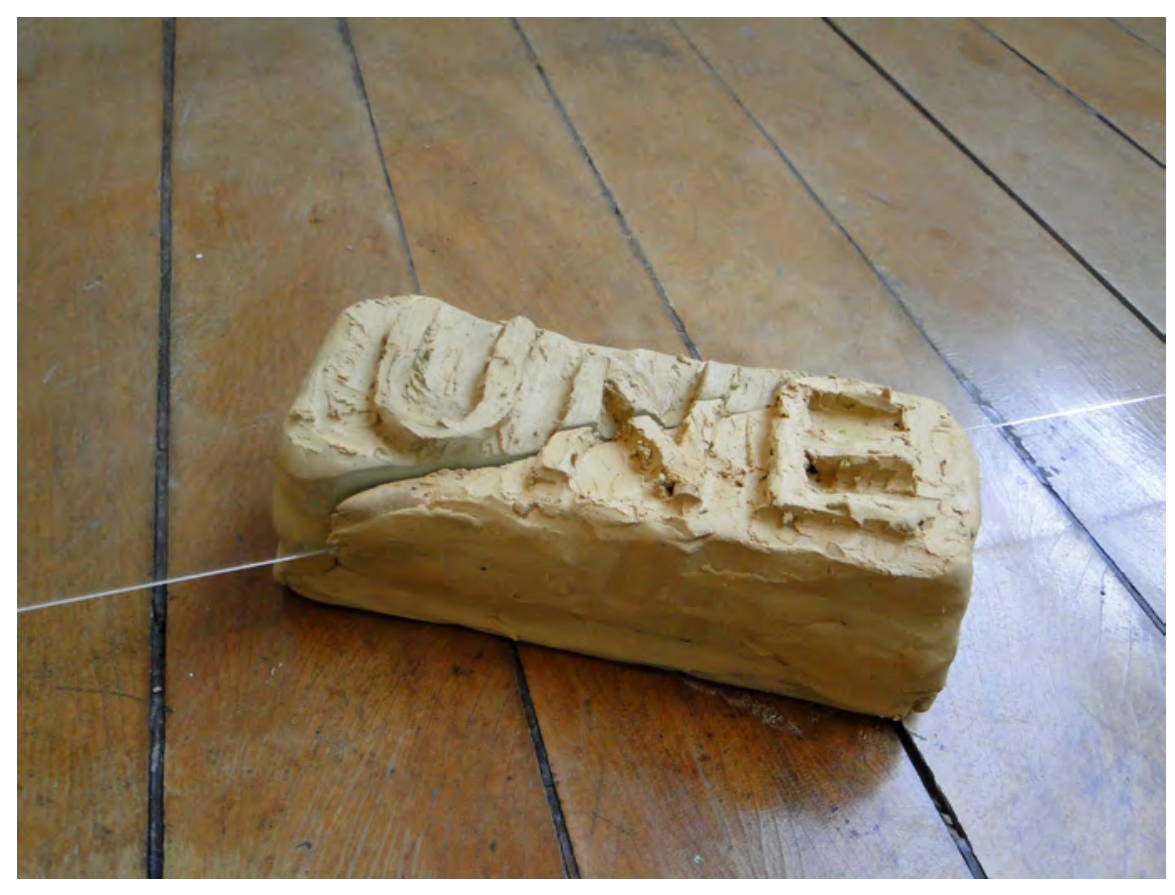

por Finlay para a construção do trabalho, como também sugere possibilidades de leituras adicionais que o espectador poderá usar como ajuda na interpretação da obra. É possível entender isso como um auxílio, já que contribui para uma interpretação adequada, ou como algo que atrapalha, já que favorece uma leitura em particular em detrimento de outras que o espectador poderia se interessar em perseguir. ${ }^{97}$

Outra percepção da ideia de "leituras adicionais" (further readings) é entendermos que a obra de Finlay não sugere um fim contido em si, e nem um ponto de chegada. Ou seja, ao inseri-la em múltiplas constelações de autores e citações, propõe que a obra, ou o exercício de sua leitura, desemboque em outros rios, num fluxo contínuo de remissões e sentidos, mantendo-a assim constantemente aberta, em curso.

A reflexão sobre curso e discurso deságua novamente em Heráclito a partir da leitura que o pensador e tradutor Donaldo Schüler faz da obra do filósofo grego. No livro Heráclito e seu (dis)curso, o autor se debate com a dificuldade de tradução da palavra logos do grego para o português, pois, em nossa língua, logos “esqueceu” da qualidade fluída do (dis)curso dos rios. Diante da problemática e na tentativa de restaurar a conexão, Schüler evoca João Cabral de Melo Neto contra a melancolia de uma tradução débil:

97 No original, em inglês: This reference matter, which is integral to the formal and material coherence of the work, both offers indications as to the sources on which Finlay has drawn in making it, and suggests further readings that the viewer might undertake as an aid to interpreting the work. It is possible to see this either as help, insofar as it contributes to a proper interpretation, or as a bindrance in that it privileges a particular reading over and above others that the viewer might wish to pursue. In: ARCHER, Michael. Catálogo da Chelsea College of Art and Design. Londres, 2005, p.9. Capturado em 06 jan. 2012. Online. Disponível em: <http://www.chelsea.arts.ac.uk/media/oldreddotassets/wwwchelseaartsacuk/docs/ research_at_chelsea6.pdf.> 
Poderíamos, ao traduzir Heráclito, manter logos em grifo, declarando a indigência da nossa língua ante a riqueza dos recursos verbais do povo que se aloja nas origens da cultura ocidental. Em vez dessa opção melancólica, preferimos manter diálogo distante com textos que a tradição nos legou e o fazemos, no caso vertente, através de João Cabral de Melo Neto. Entendemos que as definições de discurso ensaiadas pelo poeta em "Rio sem discurso", em parte já colhidas nas considerações precedentes, podem levar à absorção de logos fazendo-o fluir, transfigurado, na língua portuguesa (Shüler 2000: 21).

Para construir o seu leitor e a imagem desejada para a tradução de logos, Schüler cita o poema de João Cabral de Melo Neto na íntegra no meio do seu texto:
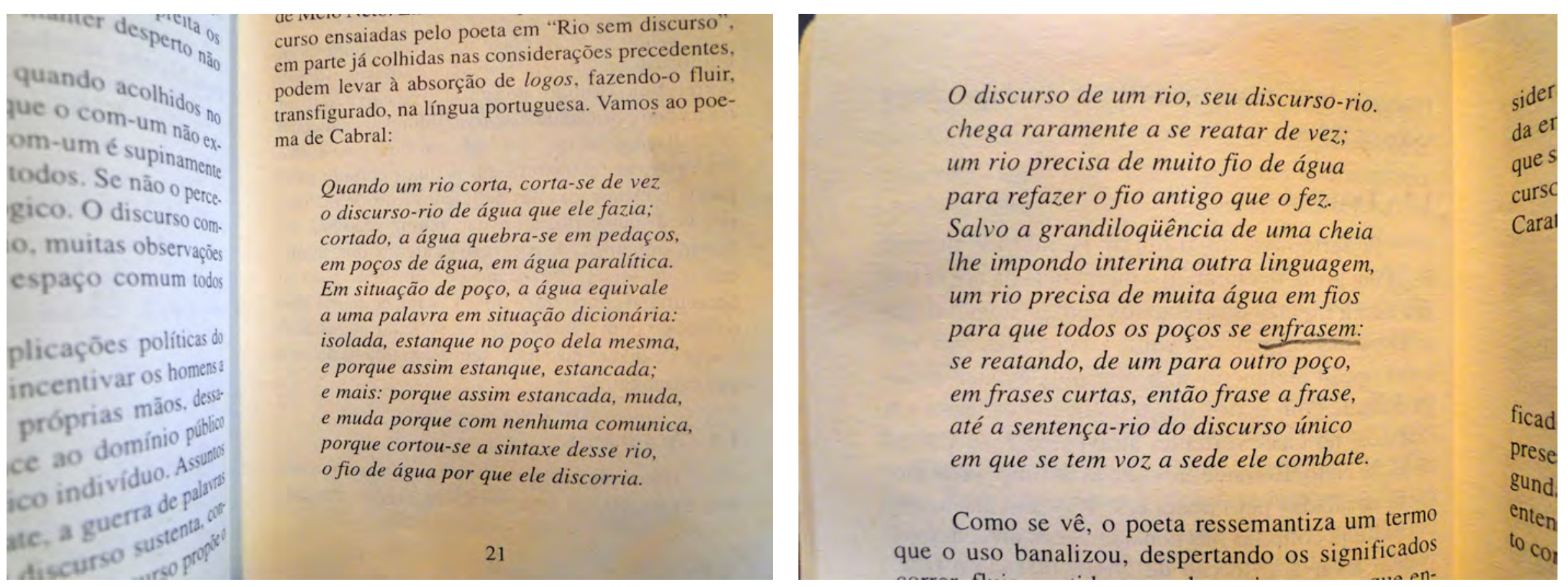

Fotografias das páginas 21 e 22 de Heráclito e seu (dis)curso, de Donaldo Scbüler, 2000. 


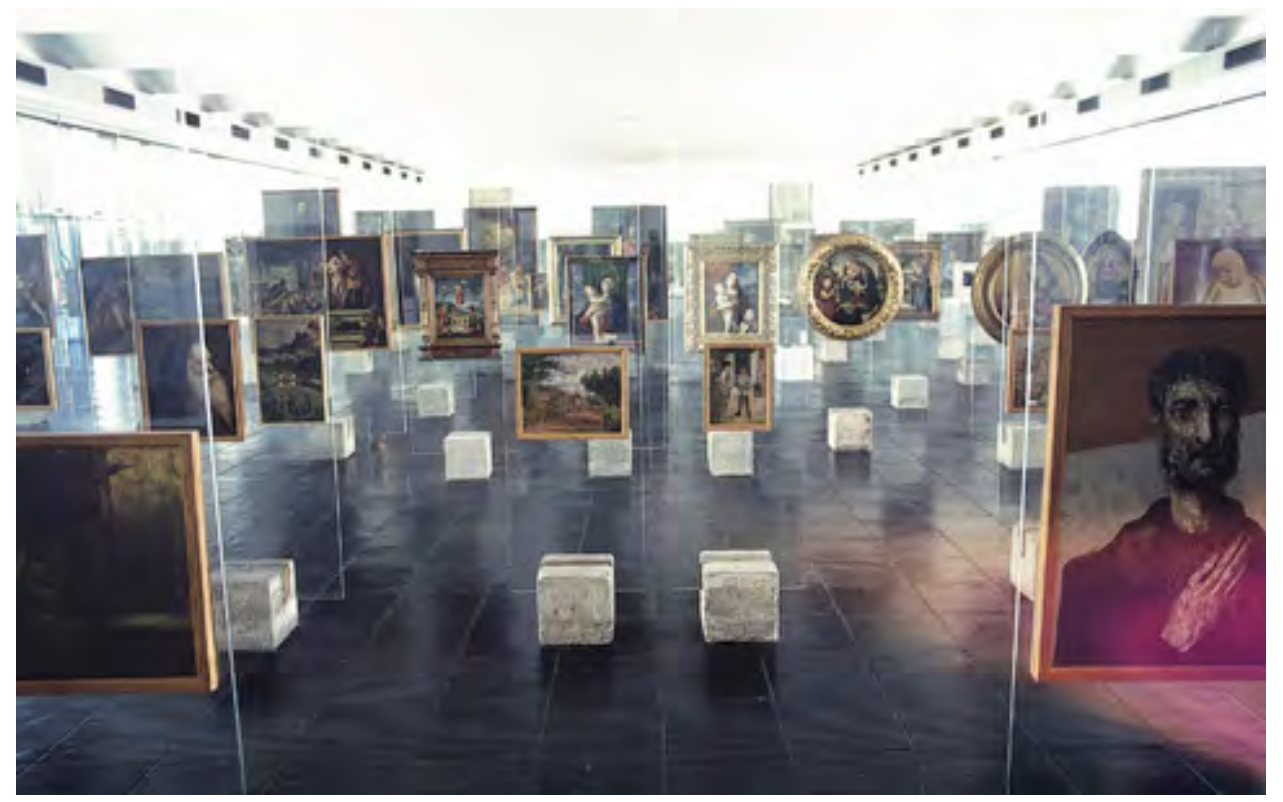

A provocação para further readings é igualmente proposta pelo projeto Concreto, seja na remissão feita pelo título ao mundo dos concretos irmãos Campos e Pignatari, conforme já mencionado, ou obviamente ao próprio Ian Hamilton Finlay. Além delas, há uma outra que diz respeito à espacialização da hobra, com implicações diretas na sua leitura, tornada ato. $\mathrm{O}$ projeto revisita os cavaletes de vidro que Lina Bo Bardi construiu para o MASP na década de 1960. A qualidade que busquei na retomada foi a desconstrução da linearidade narrativa que as estruturas da arquiteta propuseram na espacialização de um grupo de pinturas. Na hobra Concreto, o jogo de aproximações e sobreposições inusitadas se dá entre as palavras que integram a instalação. Nessa estruturação, a ordenação dos termos passa a ser

Cavaletes de vidro de Lina Bo Bardi para o MASP, 1968. organizada a partir do ponto de vista do leitor e de sua navegação pelo espaço expositivo, desmanchando portanto a linearidade/ordem dada a priori e instaurando um campo fértil e propício ao acaso.

O giro proposto por Lina Bo Bardi, ao dar transparência ao suporte das pinturas, aniquila a estabilidade de um discurso curatorial ou institucional dados de antemão. A linha da narrativa passa a ser traçada a partir da posição que o visitante ocupa, sobre quem também recai a responsabilidade da construção de sentido enquanto navega. O que se espacializa portanto, é o ato da leitura, ao qual se agrega uma qualidade performativa.

O estilhaçamento de uma frase em palavras, a qualidade explicitamente remissiva e o aspecto performativo da leitura - questões desenvolvidas no presente texto até agora - reverberam em outra obra de Finlay. Consiste em uma frase de Saint-Just entalhada em enormes blocos de pedra igualmente situados em Little Sparta. A frase é: "The present 


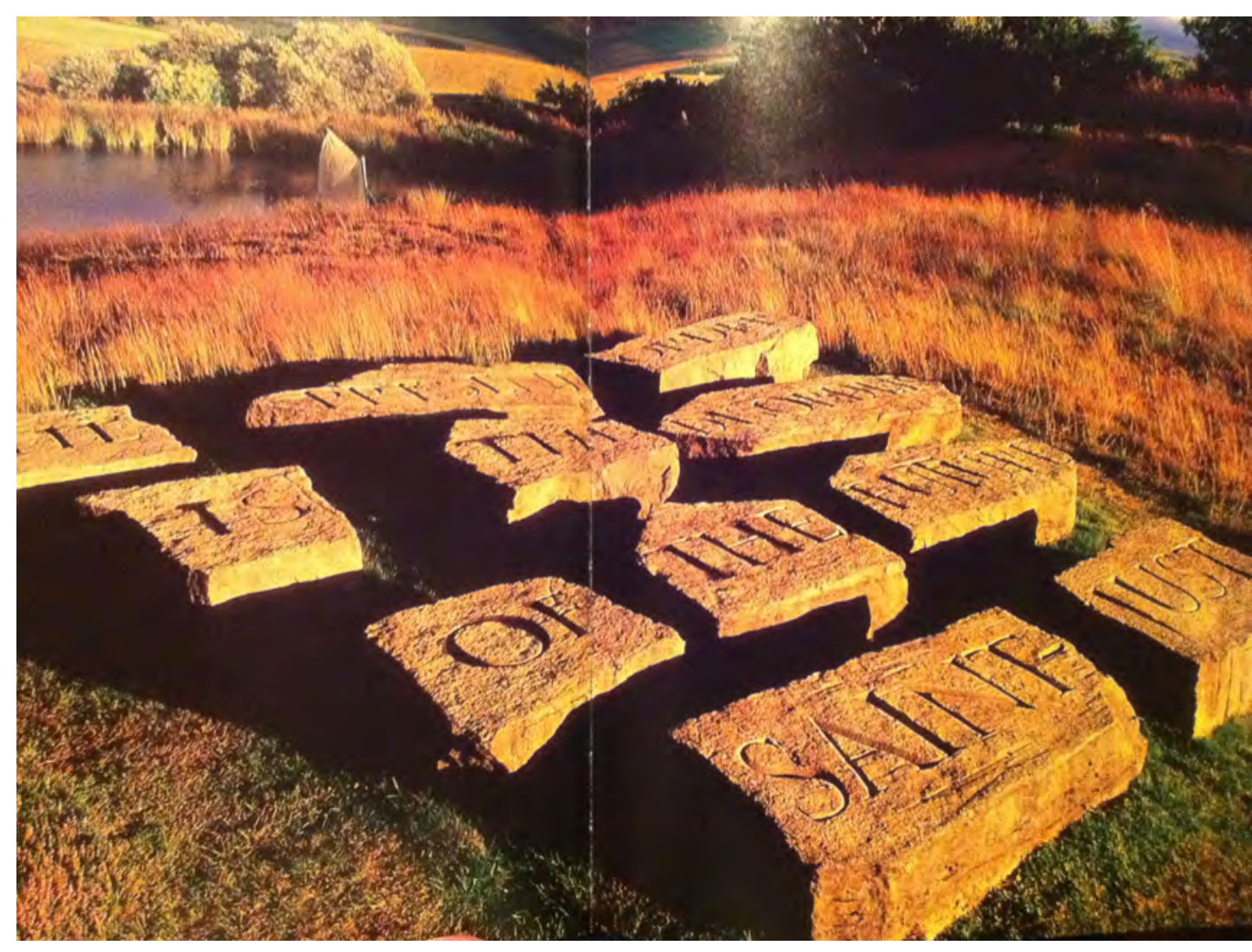

order is the disorder of the future" ${ }^{98}$. Cada palavra foi inscrita em um bloco distinto, sendo que o nome do autor da frase recebe o mesmo tratamento que o seu texto. Ou seja, é entalhado na pedra e fraturado.

O peso e a dimensão impressos na espacialização da obra conferem à citação uma qualidade aparentemente definitiva e inabalável, uma condição lapidar. No entanto, o encontro com a obra in situ dilata os seus poros e abre possibilidades de leitura até então inimagináveis a partir de sua fotografia. A cada movimento diante, ao redor e sobre os blocos de pedra, abrem-se novas possibilidades de organizar a ordem dos termos, atualizando assim o conteúdo da própria frase, ao desordená-la.

A frase de Saint-Just pode ser lida a partir da ideia de que algo desestruturador ocorre no percurso entre o presente e o futuro, uma espécie de desvio desconstrutivo que o olhar do presente não consegue alcançar, e por isso ganha a qualidade de desordem. Sabendo que seu autor viveu durante o momento da Revolução Francesa e atuava na esfera pública, seu insight pode ser lido à luz da ideia de ordem e desordem social e política, ligadas à troca de poderes que se antagonizam. Distante daquele contexto histórico, Finlay revisita as palavras enquanto texto já esvaziado do contexto ao qual se referia mais diretamente, possibilitando-lhe um novo olhar. Em relação ao presente de Saint-Just, Finlay está no futuro e a desordem prevista se faz valer no desmanche do texto original. Assim, a partir de uma leitura atenta, Finlay faz o conteúdo da frase voltar-se sobre ela própria. Nesse momento,

98 Em português: “A ordem presente é a desordem do futuro" (tradução minha). 


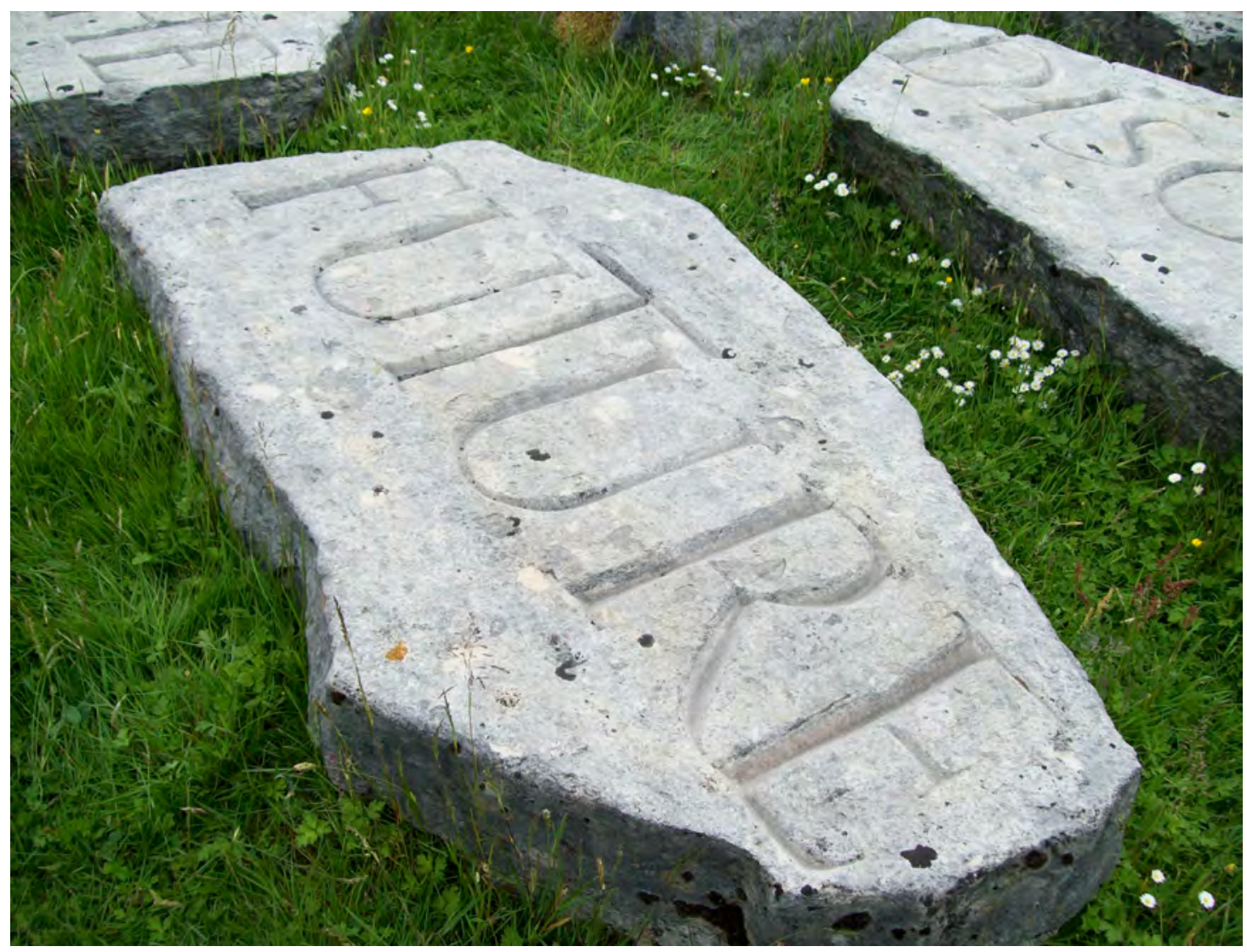

retorna da condição de leitor de Saint-Just para a de autor, instaurando, com a desordenação, uma nova ordem, um novo presente.

O movimento de sucessões é atualizado ao visitarmos a obra. Numa primeira abordagem, percebemos a relação entre os autores: o estilhaçamento da frase de Saint-Just feito por Finlay, que lhe confere uma nova e marcante espacialidade. A medida que percorremos a instalação, as palavras passam a revelar outras possibilidades de associação e o eixo de observação muda de: "olhe o que o artista fez!” para "olhe o que é possível fazer!”. Gera-se a oportunidade, a partir das frestas sugeridas, de tornar-me o futuro de Finlay, o leitor desordenador, desviante, um desleitor.

\subsection{Só a voz de quem lê despetrifica, reconduz à vida ${ }^{99}$}

A desleitura feita por Finlay de Saint-Just também lança mão da tradução interlinguística. Saint-Just era francês, e Finlay faz a passagem do seu texto para o inglês. Para Artur Nestrovski, tradutor de Harold Bloom, “a verdadeira tradução não é outra coisa senão uma forma de leitura; vale dizer, de desleitura" ${ }^{100}$. O que Nestrovski chama de uma "verdadeira tradução" não é aquela servil, invisível, transparente. A verdadeira tradução, paradoxalmente, combate uma suposta verdade única contida no original, vertendo-a por novos veres, que veem não apenas a coisa que verte, mas o (im)próprio verter.

99 SCHÜLER, Donaldo, 2000, p.39.

100 NESTROVSKI, Arthur. Apud. cit. BLOOM, Harold, 2000, p.26. 


\section{Anotações}

+ E o que poderia ser o aquilo da frase de Finlay, que produz a coisa quando vertido para o português concreto? Uma leitura possível é pensar que aquilo pode ser o próprio ato tradutório, no que contem de pêndulo entre aproximação intensa e afastamento do original. Ao traduzir algo, aproximo-me fortemente do original, buscando relacionar-me com o que há ali de mais íntimo. A primeira leitura que faço do objeto a ser traduzido é fusional. A partir da apreensão da essência, lanço o conteúdo para um outro contexto, outra língua, outro tempo, outro ouro, em uma situação de alteridade radical.

+ Outra aproximação possível com o ato tradutório é a partir da ponte enquanto dispositivo de mediação e tradução. De acordo com Marcio Seligmann-Silva: "No seu pequeno texto de 1990 'Pontificar' ele (Villém Flusser) explora a ideia da tradução como construção de pontes. Aí ele afirma que os pontífices (construtores de pontes) seriam essenciais, hoje mais do que nunca. Eles deveriam permitir o trânsito não apenas entre as diversas

T H E A N I)

rons

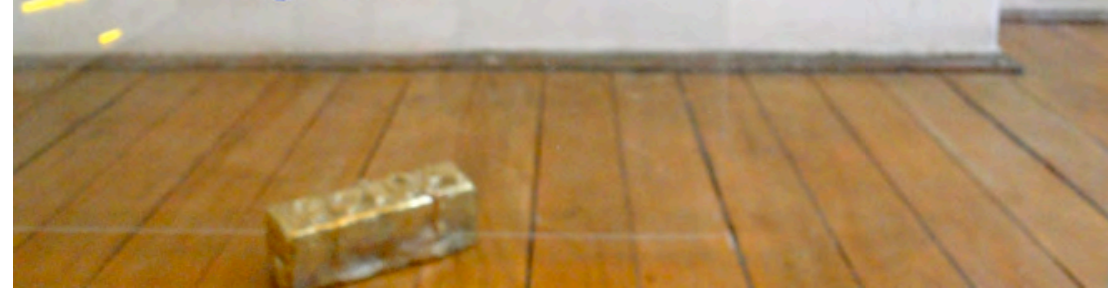
línguas (trânsito impossível, mas necessário), como também entre o discurso verbal e o imagético, entre o conceito e o algoritmo, entre a música e as demais linguagens. Traduzir implicaria um 'salto entre universos"'”ol.

+ Finlay foi um tradutor de aspectos da Poesia Concreta brasileira para o contexto britânico e da língua inglesa, estirando as hipóteses do movimento para além-mar e testando-as em um clima muito diverso daquele onde foram forjadas. Verter Finlay para a língua portuguesa fará com que as hipóteses reajam a um clima que possivelmente reconhecerão, pois está contido. $\bigcirc$ movimento de êxodo é invertido, rewinded.

101 SELIGMAN-SILVA, Marcio. De Flusser a Benjamin - do pós-aurático às imagens técnicas. Online. Disponível em <http://www.flusserstudies.net/pag/08/seligmann-flusser-benjamin.pdf > (p.5). 


\section{- Sobre tradução de poesia -}

(Zbigniew Herbert)

\section{Zumbindo um besouro pousa numa flor e encurva \\ o caule delgado}

e anda por entre filas de pétalas folhas de dicionários

e vai direito ao centro

do aroma e da doçura

e embora transtornado perca

o sentido do gosto

continua

até bater com a cabeça

no pistilo amarelo

e agora o difícil o mais extremo

penetrar floralmente através

dos cálices até

à raiz e depois bêbado e glorioso

zumbir forte: 


\section{penetrei dentro dentro dentro}

e mostrar aos cépticos a cabeça coberta de ouro $\rightarrow$ outro de pólen 


\title{
6. AMBIENTAÇÃO NÃO-CONCILIATÓRIA:
}

LINA BO BARDI

\section{Lina (2011)}

O "estar em trânsito" tem sido uma característica marcante dos trabalhadores da arte contemporânea. Residências, exposições e projetos em diferentes localidades são cada vez mais frequentes. Pode-se dizer que tem sido uma tendência na cena internacional há pelo menos uma década. Em artigo publicado em 2000, Miwon Kwon já discutia a questão:

\begin{abstract}
Ocorreu-me há algum tempo que entre muitos amigos da academia e da arte, o sucesso e a viabilidade do seu trabalho têm sido medido na proporção do acúmulo de milhas viajadas. Quanto mais viajamos a trabalho, mais somos chamados para estarmos presentes e prestarmos nossos serviços às instituições em outras partes do país e do mundo; quanto mais adotamos a lógica do nomadismo, poderíamos dizer, ao ser pressionado por uma economia capitalista do movimento, mais nos fazem sentir desejados, solicitados, legitimados e relevantes. Parece que o nosso próprio senso de autovalorização é baseado cada vez mais na nossa submissão às inconveniências e desestabilizações psíquicas do estar-em-trânsito, de não estar em casa (ou de não ter uma casa), de sempre estar em algum lugar outro. Quer gostemos ou não, somos recompensados culturalmente e economicamente ao aguentarmos e sobrevivermos ao lugar "errado". Parece que estamos deslocados com demasiada frequência (Kwon 2004: 147).
\end{abstract}

Antes de mais nada, é importante reconhecer o lugar a partir do qual Miwon Kwon fala e conjuga os verbos na primeira pessoa do singular e do plural (quem é o "nós", a quem se refere?). A autora é estadunidense e professora de História da Arte na UCLA, 
uma das principais universidades do hemisfério norte. No Brasil, a tendência nômade do mainstream da arte internacional se intensificou somente nos últimos anos, coincidindo com o fortalecimento da economia no país, com visível impacto na cultura. O fato nos permite concordar com Miwon Kwon ao perceber que o ganho de fluxo na cena artística faz parte de uma aderência à “economia capitalista do movimento” (Kwon 2004: 147).

O $32^{\circ}$ Panorama da Arte Brasileira no MAM, sob o título Itinerários e Itinerâncias, abordou a questão a partir da sua especificidade local, identificando uma produção contemporânea no Brasil sujeita a "um crescente deslocamento dos artistas e trabalhos de arte pelo globo". A pesquisa foi além e considerou a própria especificidade da arte no momento em que não mais apenas se desloca pelo mundo, mas também por diferentes áreas e saberes. Perguntam os curadores Cristiana Tejo e Cauê Alves: "A especificidade da arte se desfaz na medida em que o artista contemporâneo viaja constantemente, trabalha com toda e qualquer matéria, tema ou ideia, assim como dialoga com o cinema, o som ou a literatura?"102

A questão do artista transdisciplinar parece ser recorrente dentro da própria história do Panorama da Arte Brasileira. O artista Ricardo Basbaum, que igualmente participou da edição 2011, esteve também na de 2001, mas então enquanto curador. O fato de já ter, naquela época, uma carreira sólida enquanto artista e ter atuado como curador em algumas ocasiões gerou uma importante reflexão sobre a posição ocupada, plasmada no texto de sua autoria e publicado no catálogo da mostra. Em O artista como curador, o autor discute "o trânsito do artista através de funções que ultrapassam a sua posição como simples produtor de obras de arte” ${ }^{103}$. Nele, situa a condição fluída do artista - além da sua como artista-curador, também a de outros da exposição - não somente na contemporaneidade, mas enquanto um fenômeno da modernidade ${ }^{104}$. De acordo com Basbaum,

102 As citações desse parágrafo referem-se ao texto dos curadores enviado por email. Remetente: Cauê Alves.<alves.caue@uol.com.br> Assunto: Re: re: panorama. 08 jun. 2011. Destinatário: Jorge M. Menna Barreto <jorgemennabarreto@gmail.com>

103 BASBAUM, Ricardo. In: Catálogo da Mostra de Arte Panorama. MAM-SP, 2001, p.35.

104 Ibid., p. 35. 
não se trata de "ser artista todo o tempo", impondo o pensamento artístico aonde quer que se vá e ignorando as especificidades de cada área pela qual se transita. Trata-se muito mais de trazer um certo "tempero" 105 específico da arte para outras áreas, respeitando as singularidades de cada campo. O texto reverbera em outros escritos de Basbaum, onde desenvolve o seu conceito de artista-etc., distinguindo-o do artista-artista:

Quando um artista é artista em tempo integral, nós o chamaremos de "artista-artista"; quando o artista questiona a natureza e a função de seu papel como artista, escreveremos "artista-etc" (de modo que poderemos imaginar diversas categorias: artista-curador, artista-escritor, artista-ativista, artista-produtor, artista-agenciador, artista-teórico, artista-terapeuta, artista-professor, artista-químico, etc); ${ }^{106}$

O convite para que eu participasse do 320 Panorama foi feito de maneira direcionada, tendo sido provocado à infiltrar-me no programa educativo da instituição e propor uma obra que estivesse em relação íntima com este setor do MAM. Dirigia-se portanto à minha experiência enquanto artista-educador, como um provável reconhecimento da frequente atuação no interstício entre arte e educação/educativos que caracteriza a minha carreira. A primeira aproximação com o educativo do MAM remonta ao ano de 2007, quando, então enquanto coordenador do educativo do Paço das Artes - $\mathrm{SP}^{107}$, realizei uma visita técnica àquela instituição, acompanhado de minha equipe ${ }^{108}$. Na ocasião, fomos apresentados ao seu programa e à logística de funcionamento, visitando também os espaços e as salas usados para as suas atividades.

105 Ibid., p. 36

106 BASBAUM, Ricardo. Amo os artista-etc. (2004). Capturado em 19 dez. 2011. Online. Disponível em: $<$ http://rbtxt.files.wordpress.com/2009/09/artista_etc.pdf>.

107 Durante o ano de 2007, fui convidado a gerar e coordenar o programa educativo do Paço das Artes, SP, quando criei o Grupo de Educação Colaborativa.

108 O educativo do MAM na época estava sob a coordenação de Luciana Pasqualucci. 
Naquele ano, o MAM realizava um empenho de integração do museu ao Parque Ibirapuera, já que fora constatado que seu público diferia daquele que frequentava o parque. Ou seja, os visitantes do MAM costumavam entrar no Parque apenas para visitar o museu, partindo logo em seguida. Por outro lado, os frequentadores do parque, mesmo aqueles mais próximos que utilizavam a marquise onde o MAM está situado, não manifestavam interesse na sua programação. De acordo com o setor educativo atual, essa característica persiste. Em uma conclusão apressada, poderia especular que a localização do MAM não afeta o seu público: talvez, se o museu estivesse em um outro local, seu público seria muito parecido com o de hoje.

A questão do não-pertencimento da instituição em relação ao seu contexto imediato ecoa na história da própria arquitetura do museu, ao considerar que o prédio não fazia parte do projeto inicial do parque e da marquise, originalmente projetados por Oscar Niemeyer e inaugurados em 1954. O atual prédio do MAM foi encomendado à Lina Bo Bardi para ser uma estrutura temporária. Sua inauguração data de 1969. Bo Bardi e Niemeyer são dois expoentes da arquitetura brasileira. No entanto, sua convivência aqui se deu de maneira conflituosa, por sabidas diferenças de programa, interesses e ideologia: a arquitetura de Bo Bardi costuma ser entendida a partir de uma fundamentação mais antropológica, com preocupações contextuais, sociais e políticas; Niemeyer, que ainda hoje projeta modernos prédios-monumentos Brasil a fora, tem uma forte ênfase no desenho, o qual muitas vezes supera questões contingenciais. Poder-se-ia pensar, portanto, que a atual condição do público do parque e do museu - como se estivessem de costas um para o outro - remonta a questões históricas. A proposição que fiz, intitulada Lina, endereçava-se a esse conflito.

A intervenção Lina, na reflexão que propõe sobre Niemeyer e Bo Bardi ligada a um projeto educativo, têm grande influência do Projeto Educativo Vazio (2008), desenvolvido em colaboração com Ana Maria Tavares e Vitor Cesar para a 29a Bienal de São Paulo. Tendo sido convidada pelos curadores Ivo Mesquita e Ana Paula Cohen para desenvolver o programa educativo da mostra, Ana Maria Tavares estendeu o convite a mim e ao 
artista Vitor Cesar. O projeto curatorial tinha como característica marcante o completo esvaziamento de todo o segundo andar do Pavilhão da Bienal do Parque Ibirapuera, tendo sido inclusive apelidada de Bienal do Vazio (o título da bienal foi: Em Vivo Contato). Inicialmente, de acordo com o texto de Mesquita e Cohen, o gesto da curadoria pretendia evidenciar uma crise da Fundação Bienal, assim como um esgotamento do próprio formato de bienais de arte no planeta, que tem se multiplicado em número, mas esvaziado de sentido. $\mathrm{O}$ vazio ao qual se referiam os curadores era um vazio simbólico portanto: "Esse gesto simbólico toma o vazio como lugar onde as coisas são em potência, pleno e ativo, ao contrário da manifestação niilista, onde as coisas deixam de ser e perdem o sentido. Ele é fonte geradora, o território do devir, com múltiplas possibilidades e caminhos, síntese da negação e da ausência." 109 Embora o convite para desenvolver o projeto educativo tenha sido tardio, a menos de dois meses da abertura da mostra, dificultando pensar o educativo numa posição que não fosse de secundariedade e prestação de serviço, procuramos responder, a partir de uma posição dialógica e crítica, ao projeto curatorial. A proposição centrou-se portanto naquilo que o projeto curatorial não contemplava ou mencionava, relacionado à arquitetura que restava uma vez que as obras tivessem sido subtraídas. Ou seja, os curadores deixavam de considerar a arquitetura de Oscar Niemeyer e toda a ideologia que a sustenta, que viria para o primeiro plano, quando o segundo andar fosse desnudado. A intenção do projeto educativo, mais do que contrapor o projeto curatorial, buscava considerar e trazer luz para o próprio contexto, físico e ideológico, que servia de suporte para o gesto dos curadores. O programa educativo baseava-se assim, em dois eixos principais, então denominados: Niemeyer dentro de Niemeyer e Lina dentro de Niemeyer. O projeto partiu de uma “operação de rotação", característica do que a artista Ana Maria Tavares tem desenvolvido no contexto de sua produção e das discussões teóricas desenvolvidas em sua tese de doutorado ${ }^{110}$. A partir da rotação de elementos de arquiteturas autorais, Tavares propõe a discussão das ideologias implicadas na construção utópica do mundo moderno. Para questionar a proposição curatorial acerca da impossibilidade

109 Texto curatorial enviado por email mediante o convite para a realização do projeto educativo.

110 TAVARES, Ana Maria. Armadilhas para os Sentidos: uma experiência no espaço-tempo da arte. 2000. Tese Doutorado em Artes Plásticas/Poéticas Visuais. ECA-USP, São Paulo, 2000. 
de esvaziamento da Bienal, a artista propos a instalação de espelhos que cobririam completamente a parede do fundo do segundo andar esvaziado do pavilhão, reverberando ao infinito o próprio pavilhão de Niemeyer. Esta seria uma intervenção objetiva e física no prédio esvaziado, a qual serviria de base para as ações educativas desenvolvidas a partir das pesquisas e da produção artísticas de Vitor Cesar e minha. A pesquisa de Vitor Cesar diz respeito a uma ressignificação da ideia de espaço público, geralmente entendido como um espaço de acesso irrestrito. Para Cesar, baseando-se em Chantal Mouffe, a construção do espaço público se dá a partir do seu entendimento enquanto um campo de conflito, onde se enfrentam diferentes projetos hegemônicos, sem possibilidade alguma de conciliação final ${ }^{111}$. De minha parte, interessava-me pensar como o projeto educativo poderia traduzir as questões implicadas pelo arquitetos, principalmente a partir de Lina Bo Bardi, já que a intervenção proposta por Ana Maria Tavares já contemplava a evocação ao arquiteto Oscar Niemeyer. Deve-se lembrar que o pensamento de Lina Bo Bardi era a favor de um "museu didático", que incorporasse uma função formadora. Evocá-la a partir de um projeto com considerações pedagógicas retoma assim preocupações da arquiteta. Num texto de Bo Bardi, refletindo sobre o Museu de Arte de São Paulo: "Não é um museu de arte antiga nem um museu de arte moderna: é um museu de arte e busca formar uma mentalidade para a compreensão da arte, uma atmosfera. As mostras didáticas inauguram uma nova maneira de expor, apresentando através de fotografias, reproduções e documentos, uma síntese do panorama histórico das artes. Os cursos incentivam o desenvolvimento das artes e sua integração ao parque industrial em expansão." ${ }^{112}$ Em acordo com muitas das ações de Bo Bardi, não só como arquiteta, mas também como agitadora cultural, o eixo Lina dentro de Niemeyer propunha um contraponto para a intervenção física no espaço, embasando toda a programação do projeto educativo, como uma intervenção de caráter mais desmaterializado e discursivo (oficinas, encontros com artistas, áreas de convivência, vestuário para os mediadores, mapas, biblioteca, ciclo de debates, entre outros).

111 Ver CESAR, Cesar. O artista é público.2009. Dissertação de Mestrado em Artes Plásticas/Poéticas Visuais. ECA-USP, São Paulo, 2009.

112 Texto de Lina Bo Bardi sobre o Museu de Arte Moderna da Bahia. In: MAZZUCCHELLI, Kiki. Revista Marcelina Artista-Arquiteta, São Paulo: Ed. Faculdade Santa Marcelina, 2011, p. 35. 
A partir dos dois eixos propostos, considerando os pensamentos de Oscar Niemeyer e Lina Bo Boardi, buscávamos ancorar a criticidade proposta pelo discurso curatorial em um contexto que considerasse a própria fundação do modernismo arquitetônico brasileiro e seus antagonismos, evidenciados nas figuras dos arquitetos evocados. Embora o projeto tenha sido inicialmente aprovado, acabou sendo cancelado duas semanas antes da abertura do evento. Ironicamente, o aspecto arquitetônico, publicamente desconsiderado pela curadoria inicialmente, acabou por definir o nome dado ao segundo andar: "planta livre", termo usado em arquitetura para referir-se a uma característica típica das construções modernas, substituindo o foco inicial dos curadores de crítica-institucional por uma reflexão sobre a arquitetura, na qual o “vazio" foi substituído por "livre”.

\subsection{Lina}

O atual setor de acessibilidade do educativo do MAM dispõe de uma infraestrutura de audioguias que são disponibilizados na recepção do museu mediante solicitação. A cada mostra, uma equipe especializada se responsabiliza por sua produção, criando um discurso mediador-educativo sobre as obras em exposição. Em geral, o serviço de audioguias é direcionado a um público específico: a comunidade de deficientes visuais ${ }^{113}$. Tal especificidade gera a necessidade de se pensar em um texto que não seja apenas descritivo, mas que de fato traduza a exposição para o discurso verbal. A proposição intitulada Lina tomava os audioguias como base, embora pretendesse ampliar o seu público. Ou seja, uma vez realizada a intervenção, os dispositivos seriam anunciados na recepção do museu e ficariam disponíveis para a totalidade do público da exposição, que poderia solicitar o serviço se assim o desejasse.

A ideia foi então criar um ambiente sonoro para a voz da locução. O som a ser utilizado seria captado na marquise do parque, que, em momentos de maior movimento, funciona como uma caixa acústica, reverberando e ecoando os ruídos ali produzidos: ska-

113 Há também os vídeo-guias direcionados à comunidade de deficientes auditivos. 
tistas rasgando o chão, música, vozes, vendedores de lanches, etc. Todos se misturam em uma cacofonia e podem até mesmo tornar difícil um diálogo no ambiente. O som gravado seria enxertado então nos audioguias, construindo uma espécie de pano de fundo, um contexto sonoro para a narração sobre as obras.

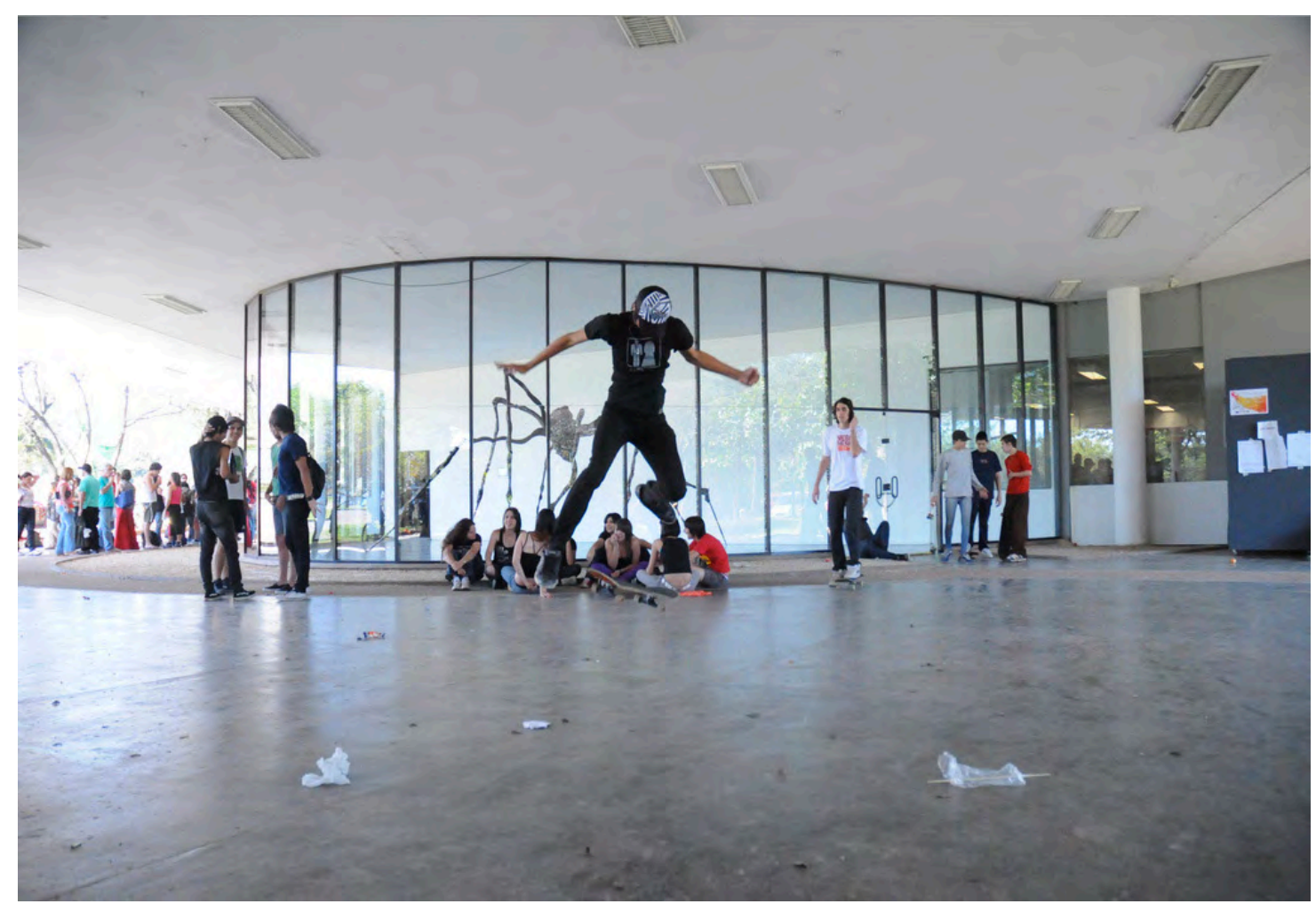

As ideias de paisagem, pertencimento e contexto são chave para a leitura da proposição. Ao dar mobilidade ao ambiente sonoro da marquise e inseri-lo nos audioguias, a operação situa o texto claro e didático da mediação na sonoridade caótica e pulsante da paisagem externa do museu. A permeabilidade ao lado de fora do MAM, que põe o museu em contato com a paisagem externa, planejada por Burle Marx, já havia sido pensada pela própria arquiteta Lina Bo Bardi, ao utilizar uma membrana de vidro que envolve grande parte do prédio. A intervenção que propus conservava a pulsão de permeabilização do museu ao seu lado de fora. Porém, evocava a paisagem sonora que os vidros repelem. Tal produção sonora faz parte de encontros espontâneos que acontecem diariamente na marquise, como uma produção residual da arquitetura de Niemeyer.

Skatista na marquise do Ibirapuera, com parede de vidro do $M A M$ ao fundo.

Incluir uma sonoridade desordenada e não-linear enquanto subcamada de um espaço narrativo e normativo não cria exatamente uma integração harmônica entre o dentro e o fora. $O$ contraste faz manter a tensão, a conserva irresoluta. Dessa maneira, não coincide com o desejo da instituição de endereçar-se ao problema da disjunção entre o museu e seu entorno de maneira conciliatória. O que se pretende em Lina é dar visibilidade ao conflito, ou audibilidade: não uma resolução. 
O projeto descrito foi proposto e aprovado pela curadoria do Panorama, mas não chegou a acontecer, pois a marquise do Ibirapuera estava sendo submetida a uma reforma durante vários meses, que incluíam tanto o período de produção da hobra como o da exposição. Faz parte da tese pelas mesmas razões da obra Concreto, descrita anteriormente. A diferença é que o leitor só foi informado da sua não-existência agora, ao final do texto. $\mathrm{O}$ atraso na notícia é intencional e joga com os diferentes papéis que o texto tem assumido na tese: revisionista, documental, constitutivo e espaço de acontecimento.

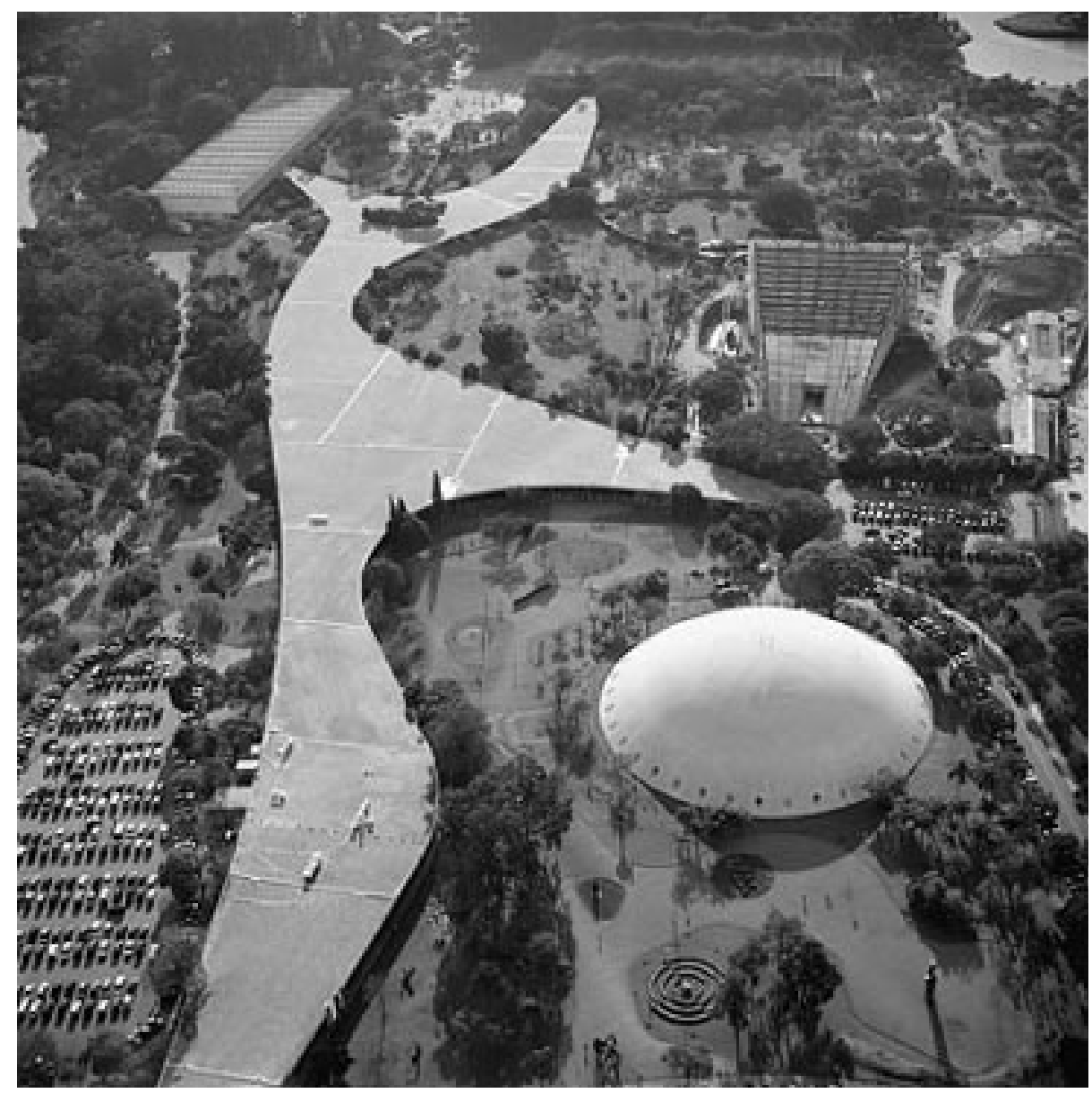

Marquise do Ibirapuera, vista aérea. 


\section{poet ...}

The words of a dead man

Are modified in the guts of the living

W. H. AUDEN, 'In Memory of W. B. Yeats'

ebruary 2006 at the age of eighty

iterpretative management of his

sugh the commentaries of others,

us how we might read his works. 


\section{TRADUÇÃO DIGESTIVA: HÉLIO OITICICA}

\section{Metabólide}

Exposição Transfronteiras Contemporâneas, Memorial da América Latina (2010)

Esta hobra foi concebida ao escutar os sucos gástricos que banham as páginas do livro Aspiro ao Grande Labirinto (1986) de Hélio Oiticica (1937-1980). O texto é espaço de elaboração, onde se percebe a deglutição, o engolir, os movimentos peristálticos, os ácidos críticos da saliva e do estômago que transformam a matéria e a preparam para a absorção. A apreensão do outro pelo sistema digestório é lenta. Envolve uma extensa jornada que atravessa o corpo e aciona intensos processos químicos e mecânicos de decomposição. Cada pedaço de alteridade tem que ser mastigado e vigorosamente modificado, quebrado em moléculas. As microvilosidades do intestino constituem um sistema complexo e amplo de absorção, onde o que se aproveita é cuidadosamente selecionado, deixando de lado o residual. É muito diferente dos processos de incorporação pela visão, nos quais há uma imediaticidade enganosa, uma apreensão da aparência projetada no fundo da retina, inicialmente ao contrário e depois retificada pelo cérebro. O olho acelera o processo de captura. Sua função não é a de absorver a alteridade, mas de detectá-la e reconhecê-la. A alteridade só pode ser absorvida lentamente, mastigadamente, engolidamente, digestivamente, antropofagicamente. A radicalidade maior da antropofagia está na mudança, no desvio de modo e temporalidade na percepção do outro. Deixa-se de usar o mecanismo ótico para usar o digestivo, que também envolve órgãos de leitura, mas não da imagem, e sim do valor nutritivo da matéria-outro, reconhecendo o que deve ser ou não absorvido. $\mathrm{O}$ sistema digestivo desmancha e quebra em moléculas: proteínas, vitaminas, carboidratos, etc. Faz um reconhecimento da corpo alheio que não opera a partir de uma aparência identitária, mas da desconstrução dessa imagem que é esfacelada, reduzida a partículas que são lidas e organizadas enquanto matéria nutritiva. Participa-se assim do 
avesso daquilo que se vê - intimidade molecular. Aspiro ao Grande Labirinto é um longo tubo digestivo, e o tempo, seu aliado ${ }^{114}$.

Bergson, Mondrian, Malevitch, Seurat, Robert Delauny, Kandinsky, Sophie Tauber-Arp, Tatlin, Lygia Clark, Goethe, Matisse, Picasso, Klee, Pollock, Wols, Fontana, Gullar, Worringer, Cézanne, Albers, Merleau-Ponty, Schwitters, Calder, Kupka, Arp, David Smith, Brancusi, Braque, Juan Gris, Gabo, Pevsner, Boccioni, Max Bill, Baumeister, Dorazio, Etienne-Martin, Pollock, Mário Pedrosa, Jackson Ribeiro, Tinguely, Schöfer, Louise Nevelson, Yves Klein, Restany, Martin Barré, Hércules Barsotti, Aluízio Carvão, André Bloc, Alina Slensinska, Willys de Castro, Victor Pasmore, Amílcar de Castro, Auguste Herbin, Agam, Tomasello, Kobashi, Lardera, Jacobsen, Isobé, Di Teana, Vasarely, Willem de Kooning, Dore Ashton, Mark Rothko, Mark Tobey, Herbert Read, Rauschenberg, Jasper Johns, Kant, Nat King Cole, Marilyn Monroe, Van Gogh, Antonio Conselheiro, Lampião, Cara de Cavalo, Gerchman, Pedro Escosteguy, Dias, Lygia Pape, Waldemar Cordeiro, Alibertti, Wesley Duke Lee, Nelson Leirner, Rezende, Fajardo, Hasser, Roberto Magalhães, Carlos Vergara, Glauco Rodrigues, Zílio, Hans Haudenschild, Mona Gorovitz, Solange Escosteguy, Eduardo Clark, Renato Landim, Samy Mattar, Lanari, Smetack, Ivan Serpa, Frederico Morais, Raimundo Amado, Guy Brett, Lichtenstein, Warhol, Milton Lycidas, Nelson Motta, Ceres Franco, Jean Clay, Caetano, Lon Chaney, Gilberto Gil, Graham, Murdel, Varese, Antonio Manuel, Rogério Duarte, John Cage, Esther Stockler, Samy Mattar, Bartucci, Fellini e Miro são os nomes citados nas 134 páginas de Aspiro ao Grande Labirinto. Mais do que nomes, constituem um mapa dos autores-alimentos posicionados diante de Hélio Oiticica e seu apetite voraz:

Cada vez que procuro situar a posição estética do meu desenvolvimento, historicamente em relação às suas origens, chego à conclusão de que não só é um desenvolvimento individual muito forte e pessoal, como completa um contexto histórico e cria um movimento, junto a outros artistas. É uma necessidade de grupo, ativa (Oiticica 1986: 33).

114 A maior parte do livro consiste em anotações de diário, precedidas pelas datas nas quais foram escritas. 
A consciência histórica e contextual manifesta no trecho permeia toda a produção do artista, empenhado não somente na avaliação da produção pessoal, mas em fazer um diagnóstico da cena artística brasileira, evidente, por exemplo, no seu texto Esquema Geral da Nova Objetividade (1967), publicado no mesmo livro, no qual desenha um panorama do "estado da arte brasileira de vanguarda atual” (Oiticica 1986: 84). Hélio Oiticica faz parte de uma linhagem de artistas modernos cuja relação com o texto e a palavra é marcante, constitutiva da obra. Nas palavras de Luciano Figueiredo, na introdução ao Aspiro ao Grande Labirinto:

$\mathrm{Na}$ tradição moderna das Artes Plásticas, temos exemplos de como foi importante, para alguns artistas, a elaboração de textos onde o processo e universo criativos do artista são demonstrados em proposição teóricas e muitas vezes também poéticas. Desde os escritos dos construtivistas, os manifestos das vanguardas do início do século, aos textos de Mondrian, Arp, Duchamp, este legado teórico permanece como formulação profunda de cada artista em relação à própria obra, e como visão de mundo ${ }^{115}$.

\subsection{A exposição}

Transfronteiras Contemporâneas foi o título da mostra no Memorial da América Latina (SP), em 2010, cujo intuito primeiro era comemorar o Bicentenário de Independência da América Latina. A exposição contava com obras de artistas da Argentina, Chile, Colômbia, México e Venezuela, países que adotaram o ano de 1810 como início de seu

115 FIGUEIREDO, Luciano. In: OITICICA, Hélio. Aspiro ao Grande Labirinto. Rio de Janeiro: Rocco, 1986, p. 5. 
processo de autonomia política em relação à Espanha. $\mathrm{O}$ convite aos artistas brasileiros buscava tornar mais complexas as relações entre as obras, como um contraponto que fugia à comemoração política e procurava intersecções culturais entre todos. A concepção de fronteira abordada pelas curadoras Angela Barbour e Rosa Cohen também abrangia aquela entre linguagens, pensando as relações da arte com as "tecnologias modernas: multimediações e intersecções das linguagens da música, da performance, das instalações”"116.

Além do contexto da exposição, o próprio Memorial já se constitui como uma importante referência. Projetado por Oscar Niemeyer e inaugurado em 1989, o complexo de seis edifícios principais ocupa uma vasta região na Barra Funda em São Paulo. Os amplos espaços livres entre os prédios têm o chão revestido por um concreto liso, como se fosse uma imensa placa. O ambiente inóspito criado mais se assemelha a um deserto cinza, pouco convidativo e que adere à lógica de uma cidade sem verde e com baixa permeabilidade à terra, com evidentes danos ecológicos. $\mathrm{O}$ complexo foi construído como um monumento "à integração cultural, política, econômica e social da América Latina"117, cujo projeto cultural foi desenvolvido pelo antropólogo Darcy Ribeiro. Sua função mediadora entre as diversas culturas foi mais bem sucedida nos anos que se seguiram a sua inauguração, mas logo se tornou um espaço de baixas visibilidade e frequência de público. A exposição aconteceu no prédio chamado Marta Traba, que, no projeto original, funcionava como restaurante.

\subsection{Metabólide}

A hobra que projetei para a exposição não foi determinada pelo contexto em sua concepção. Como já dito, partiu da leitura de Aspiro ao Grande Labirinto, a qual já vinha

116 Capturado em $1^{\circ}$ jan, 2012. Online. Disponível m:<http://www.memorial.sp.gov.br/memorial/Agenda Detalhe.do? agendaId $=1804>$

117 Capturado em $1^{\circ}$ jan, 2012. Online. Disponível em: <http://pt.wikipedia.org/wiki/Memorial_da_ Am\% C3\%A9rica_Latina>. 
me dedicando antes do convite. No entanto, a resolução formal da hobra foi definida a partir das características arquitetônicas do espaço. Além disso, parecia-me interessante rever o pensamento de Hélio Oiticica no contexto de uma exposição com um viés nacionalista e identitário. A ideia de um Brasil em construção de Oiticica, que se projeta para o futuro, mas inclui a adversidade e o precário do presente em seu eixo, criava um contraste interessante com o sonho de um continente latino-americano integrado e utópico, cujo bicentenário de independência se busca ironicamente celebrar em uma arquitetura monumental e triunfalista, pouco atenta ao contexto.

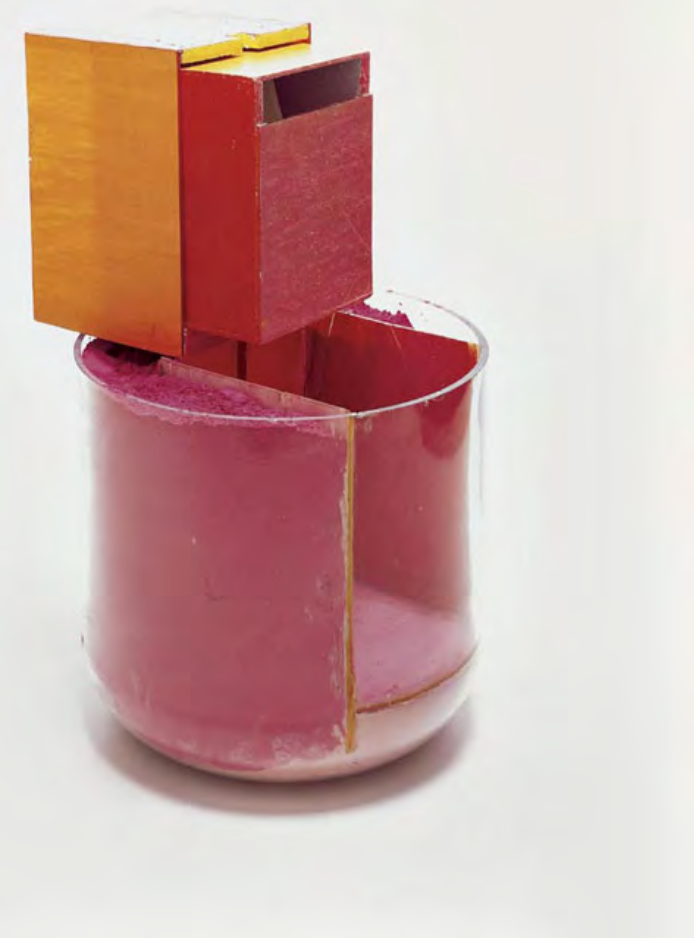

Bólide 02 (1963-64), Hélio Oiticia.
Minha pesquisa sobre tradução me fez perceber no texto Bólides, que integra o livro Aspiro ao Grande Labirinto, uma base interessante para refletir sobre o assunto. Bólide foi a denominação encontrada pelo artista para definir uma série de obras suas com determinadas características em comum. Oiticica inicia o seu texto revelando a ambiguidade do termo, colocando uma dúvida sobre a sua própria concepção ao afirmar que poderia ter chamado suas últimas obras, os Bólides, de "transobjetos" (Oiticica 1986: 63). Demonstra assim que o próprio nome não é completamente estável e que contém uma disposição para redefinir-se. Nesse texto, pude também identificar alguns rastros do pensamento tradutor do artista. Primeiro, o processo de transposição da cor-luz para a matéria-corpo: “a necessidade de dar à cor uma nova estrutura, de dar-lhe 'corpo"” (Oiticica 1986: 63). Segundo, as estruturas que dão corpo à cor muitas vezes incluem um "objeto pré-moldado" (Oiticica 1986: 63), como uma cuba de vidro encontrada pronta no comércio. O processo de transporte desse objeto para a condição de obra é cuidadosamente descrito pelo artista. De acordo com o Oiticica, não se trata de uma

simples “lirificação" do objeto, ou situá-lo fora do cotidiano, mas incorporá-lo a uma ideia estética, fazê-lo parte da gênese da obra, tomando ele assim um caráter transcendental, visto participar de 
uma ideia universal sem perder a sua estrutura anterior. Daí a designação de "transobjeto" adequada à experiência (Oiticica 1986: 63).

$\mathrm{Na}$ sua conceituação, o artista usa como exemplos negativos as operações de transposição de objetos para a obra realizadas por Rauschenberg e Jasper Johns, cuja incorporação de elementos já prontos é feita a partir do transporte do "mundo das coisas para o plano das formas simbólicas", de "maneira direta e metafórica”, sem tradução. Nos "transobjetos”, de Oiticica, o objeto é incorporado como uma estrutura que possibilita a obra: "ao procurar a cuba (de vidro) e sua estrutura implícita, já se havia dado a identificação da estrutura mesma com a da obra, não se sabendo depois onde começa uma e termina a outra." O artista descontrói assim a relação de anterioridade entre obra e objeto, propondo uma "dialética profunda" ${ }^{118}$, onde objeto pré-moldado e obra fundam uma qualidade híbrida característica do estado tradutor, trans_formador.

A própria palavra Bólide também carrega uma propriedade anfíbia, de deslocamento entre meios. De acordo com a definição, é um "Meteorito de volume acima do comum que, ao penetrar na atmosfera terrestre, produz ruído e se torna muito brilhante, podendo deixar um rastro luminoso." 119 Se equiparado ao processo tradutor, é interessante pensar que a mudança de meio não lhe confere uma perda, mas sim um ganho, um brilho que só se dá no atrito com o novo meio, tornando-o incandescente e aumentando a sua visibilidade. A hobra Metabólide apropria-se do termo Bólide como um palavra "pré-moldada”, cujas características são incorporadas de maneira constitutiva, e não como uma anexação a posteriori. O prefixo meta possui múltiplas definições. Uma delas refere-se à "revisão crítica sobre”, além de "transcendência, mudança, sucessão, posteridade", como em "metáfora, metamorfose, metafísica”. Outra definição oportuna, sem excluir as antecedentes, significa "movimento de um lugar para o outro", tal como nas palavras

118 Todas citações deste parágrafo referem-se ao texto Bólides In: OITICICA, Helio. Aspiro ao Grande Labirinto. Rio de Janeiro: Rocco, 1986, p. 63-65.

119 FERREIRA, Aurélio Buarque de Holanda.Novo Dicionário Aurélio da Lingua Portuguesa. 2 ed. Revista e ampliada. Rio de Janeiro: Nova Fronteira, 1986 p.271. 


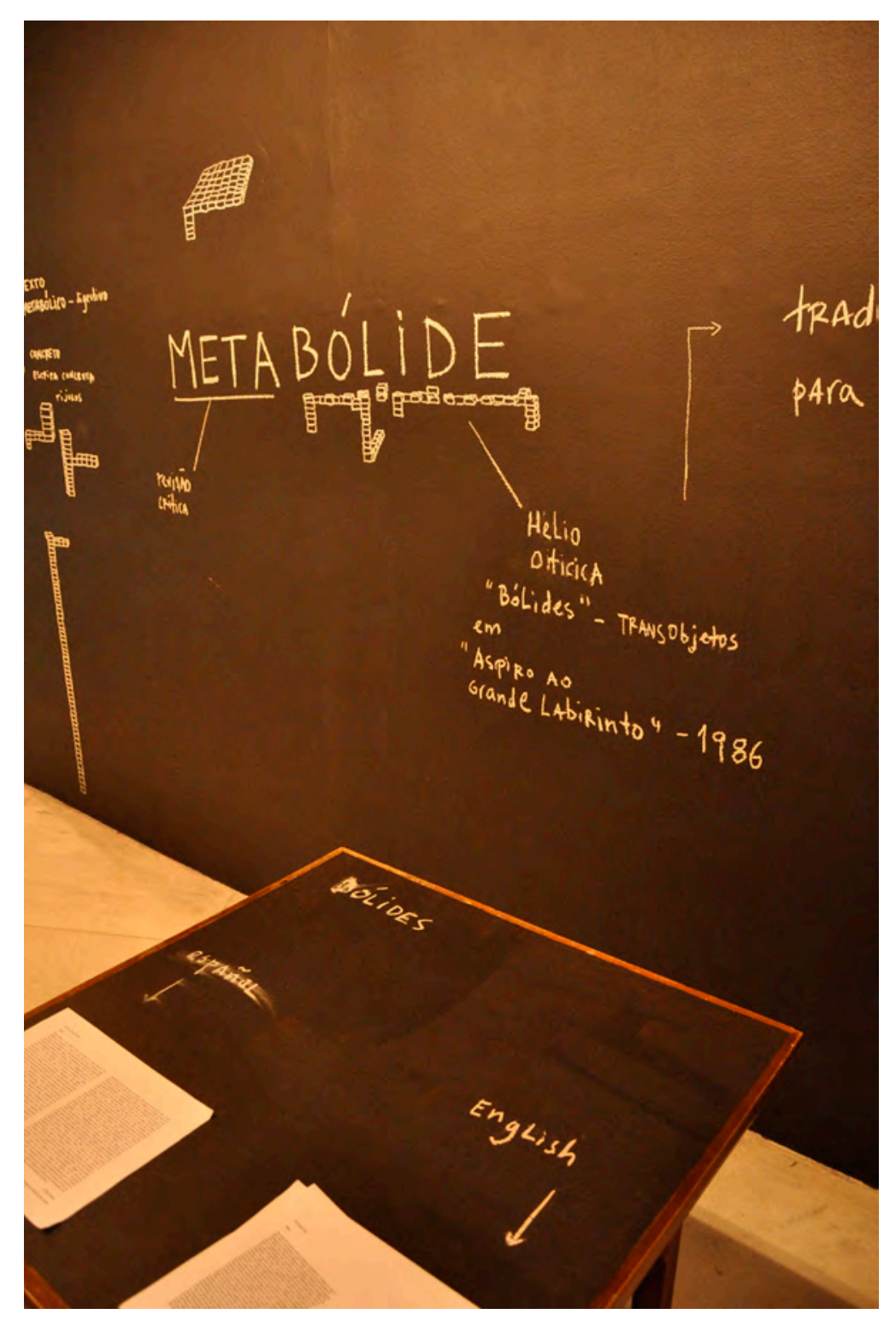

“meteoro" e "metonímia”"120. O ciclo se fecha, ou se amplia (?), a partir dessa última definição, pois coincidem os sentidos de "meta" e "bólide", somando forças. Além da operação linguística, $\mathrm{Me}$ tabólide se realiza ao ganhar corpo enquanto instalação-objeto. Sua estrutura foi feita com tijolos maciços de barro pré-moldados, empilhados dentro do espelho d'água que circunda a galeria Marta Traba para formar a palavra. Além da instalação, dentro do espaço expositivo, realizei um desenho reflexivo em giz sobre uma parede pintada como quadro-negro. Ainda, por ocasião do projeto, encomendei duas traduções do texto Bólides para tradutores profissionais: Julia Ayerbe, que realizou uma versão para o espanhol, e Gavin Adams, para o inglês. Junto ao desenho, disponibilizei cópias das traduções para o público. O texto original estava invisível. Aspiro ao Grande Labirinto é uma edição única e esgotada.

\section{Instalação na parte interna da} Galeria Marta Traba.

120 As definições do prefixo "meta” foram compiladas pelo Prof. Carlos Alberto Guimarães (UFRJ). Capturadas em 06 jan. 2012. Online. Disponível em: <http//:www.virtual.epm.br/cursos/metanalise/conteudo/.../grafia_meta.doc $>$. 


\section{TEXTO \\ METARULLIRO - digestivo}

CONCRETO

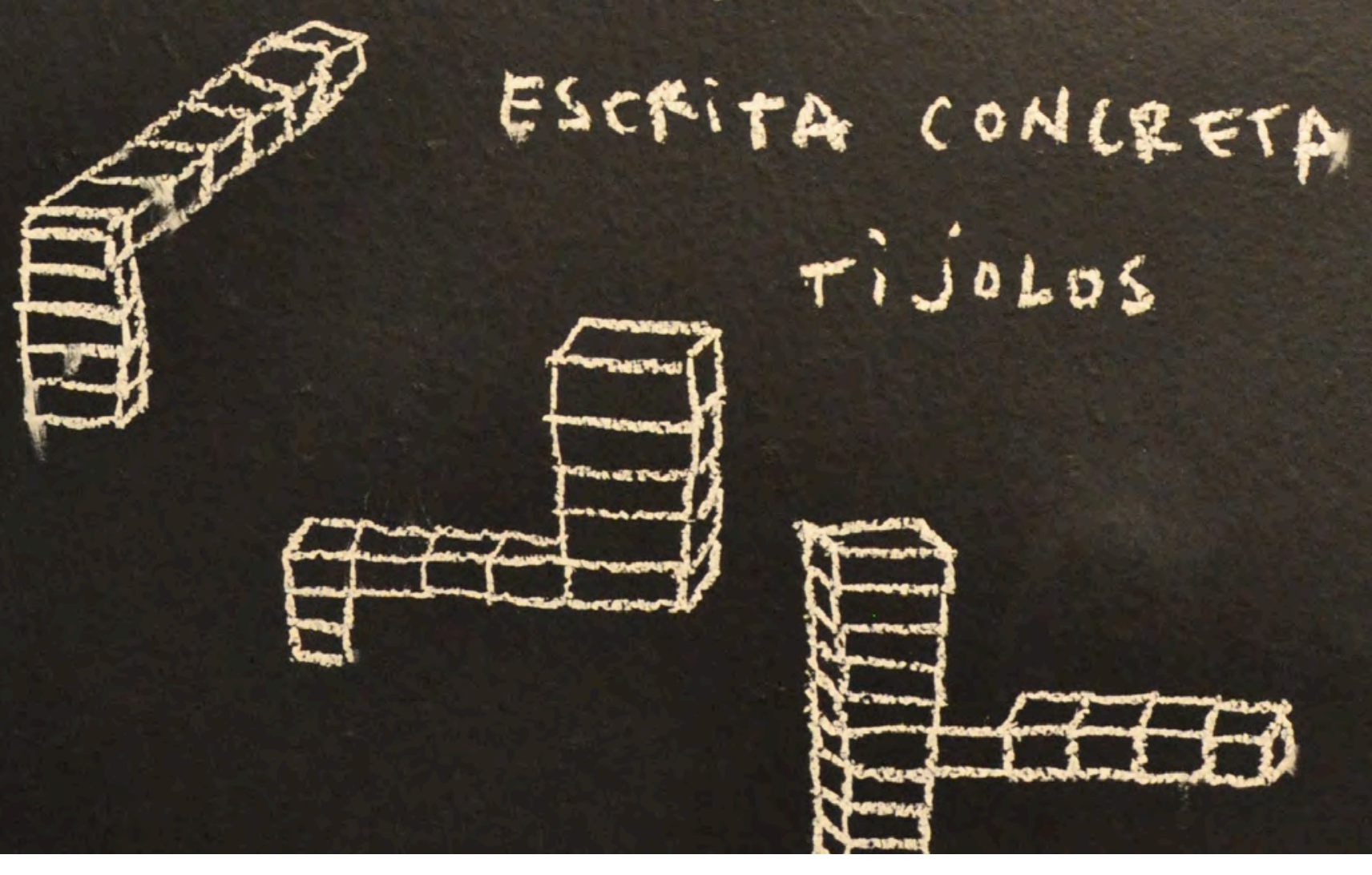



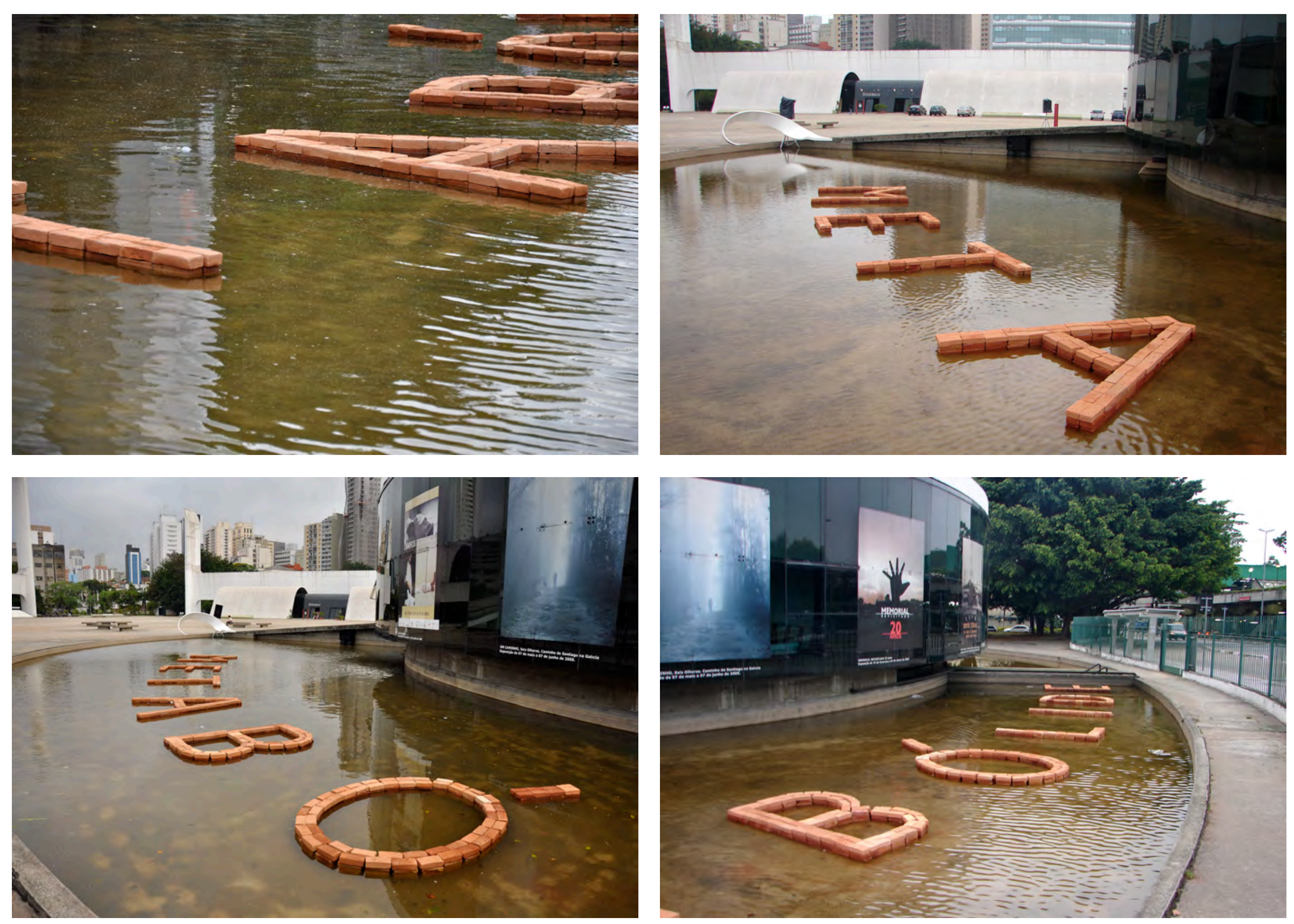


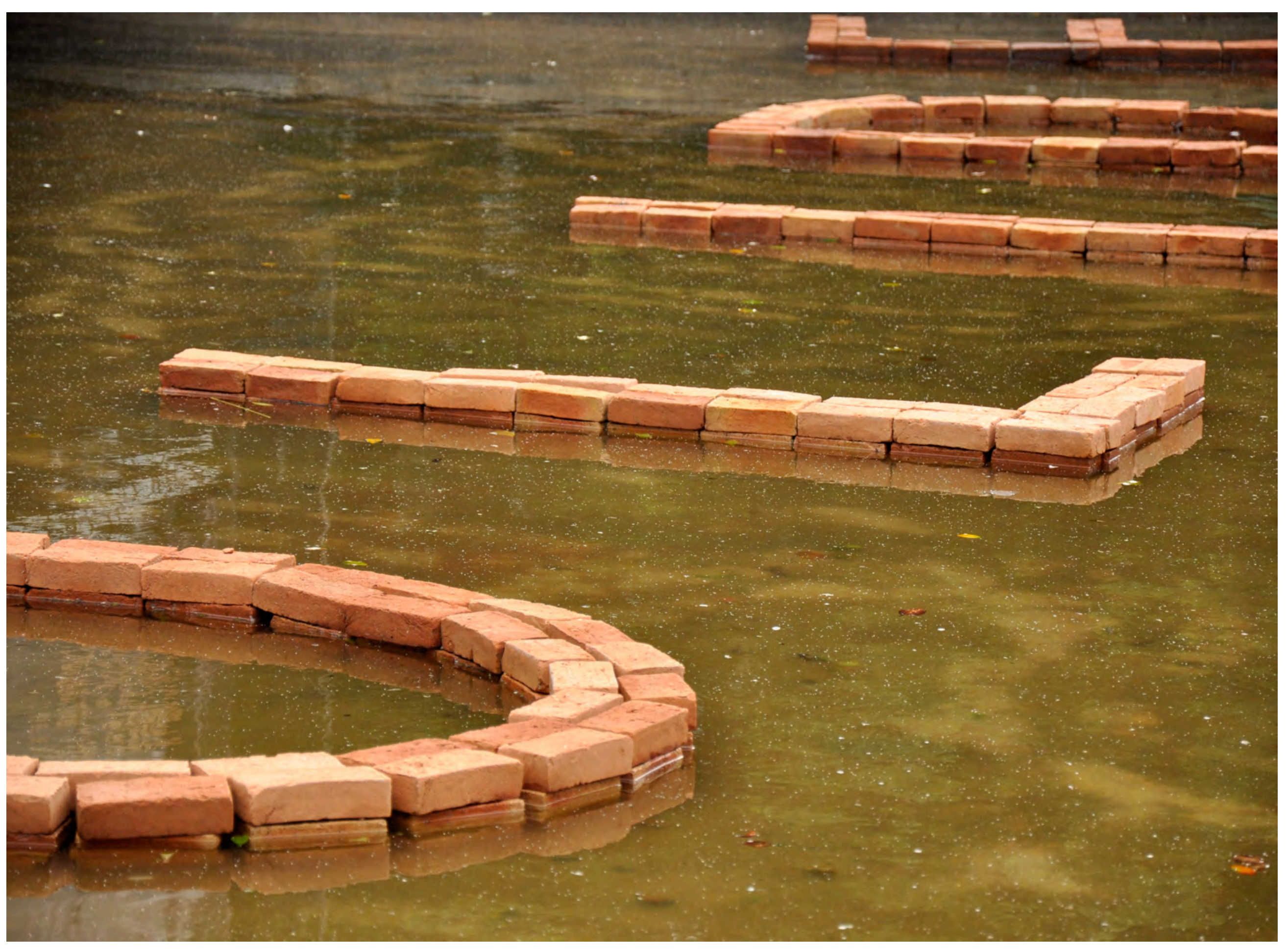



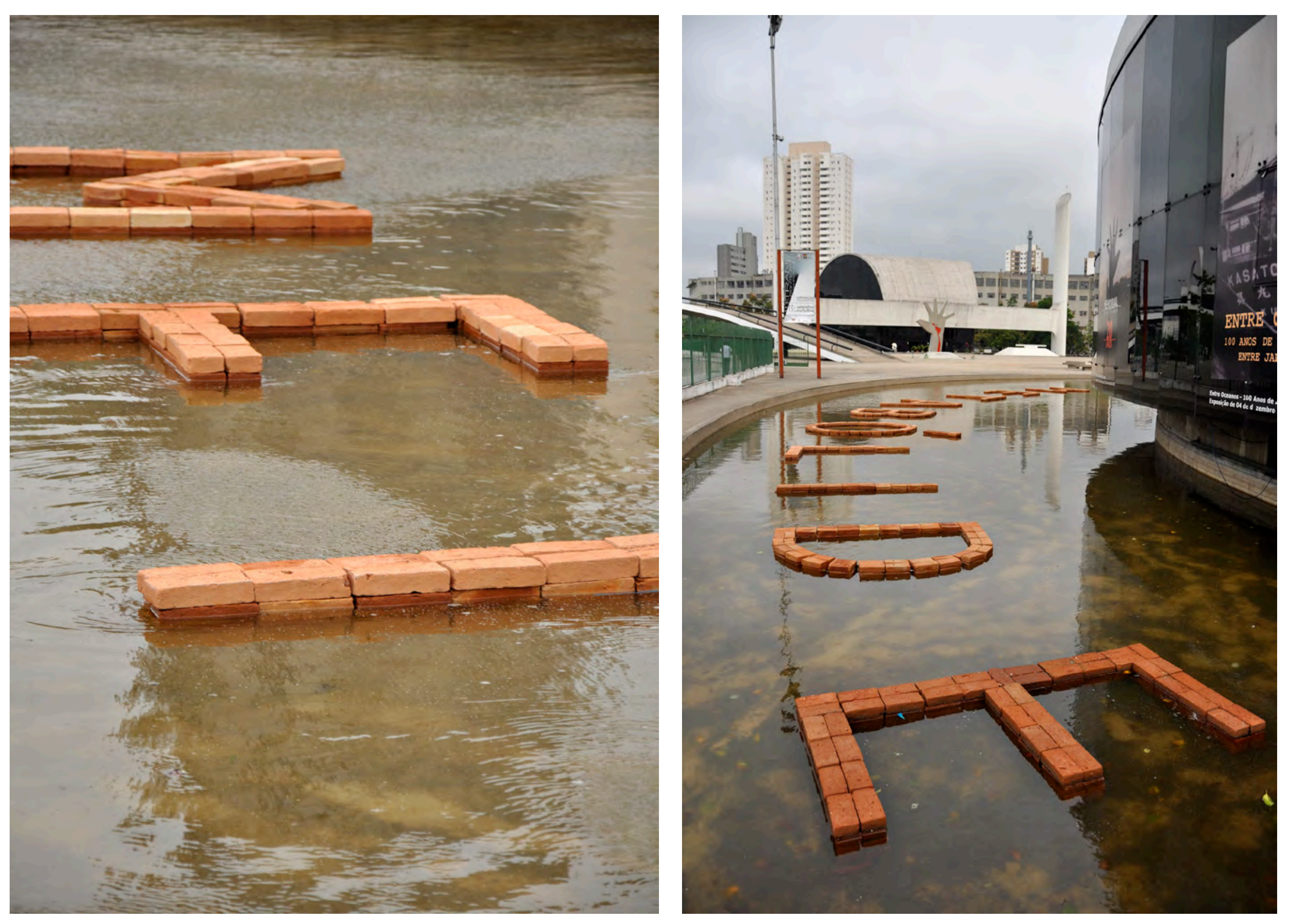


\subsection{A palavra}

Pensar a palavra em sua objetidão é uma crescente no percurso da leitura de Aspiro ao Grande Labirinto. Nas últimas duas páginas do livro, 133 e 134, sob nota de diário do dia "24 nov. 69", já não encontramos mais nomes de outros autores como antes. A atenção se dirige para um outro foco: Parafuseamento, opressionisticossocial, mútero, delgádico, tiãoconduzidas, ssfum, pretião, caixa d'aguando, marienbadescente, memori-imemoriais, crisantemais, transpassadarente, casalçada, ouropoder, gloriantiga, largavenida, redore-

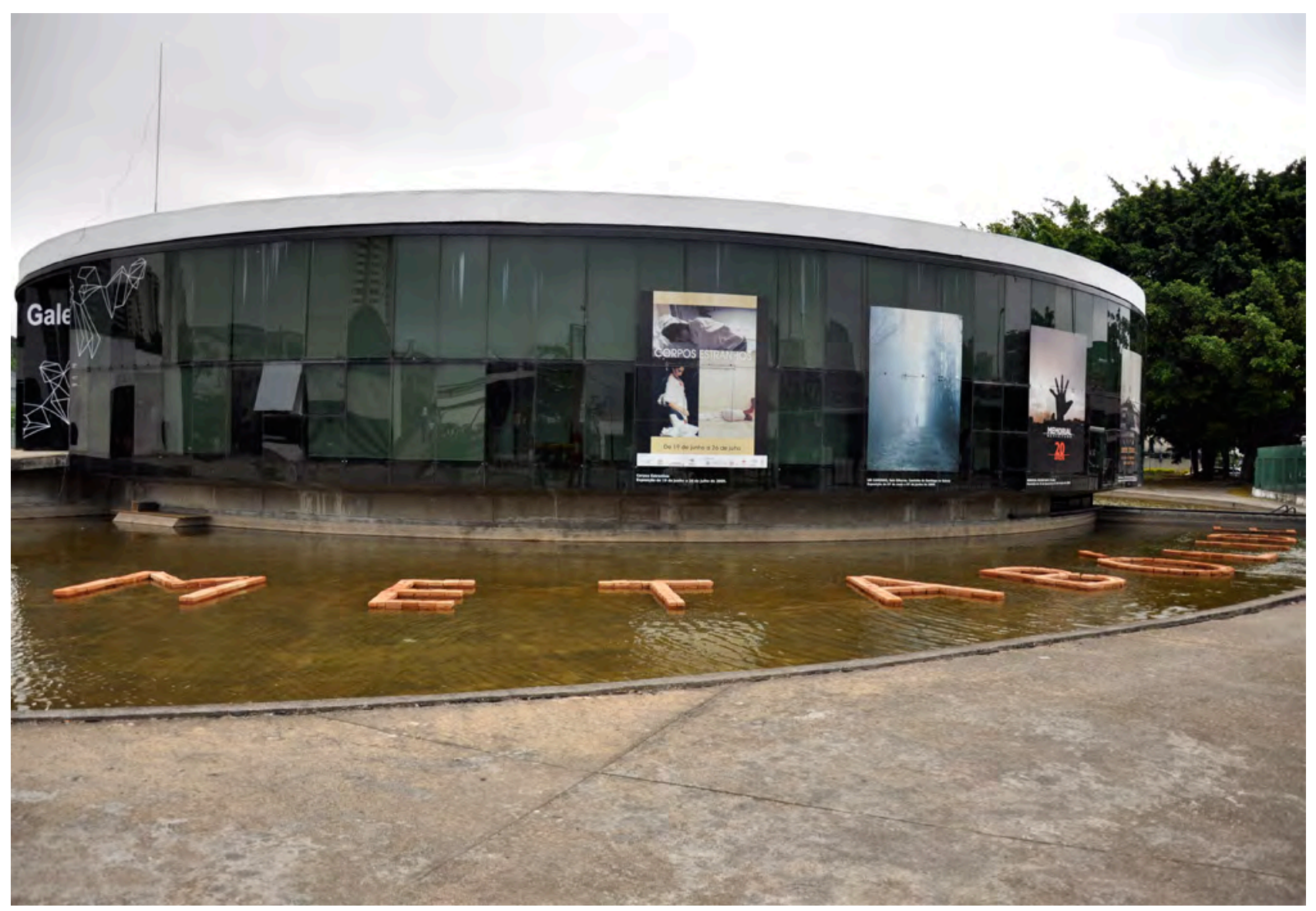
dor, distancilândios, transpi-suor, linhorência, carcoporal, tropotropical e bonomia. Considerando que são duas páginas apenas, vinte e quatro palavras inventadas tornam o texto um tanto opaco. As palavras complicam a sua função comunicativa. Já não é mais meio para tratar de ideias e autores. É a palavra que é mastigada, digerida e submetida aos sucos gástricos que a transformam em outro, outra coisa, tornoutro. A própria palavra tornou-se o objeto da leitura forte: logofagia.

Instalação no espelho d'água da Galeria Marta Traba. 


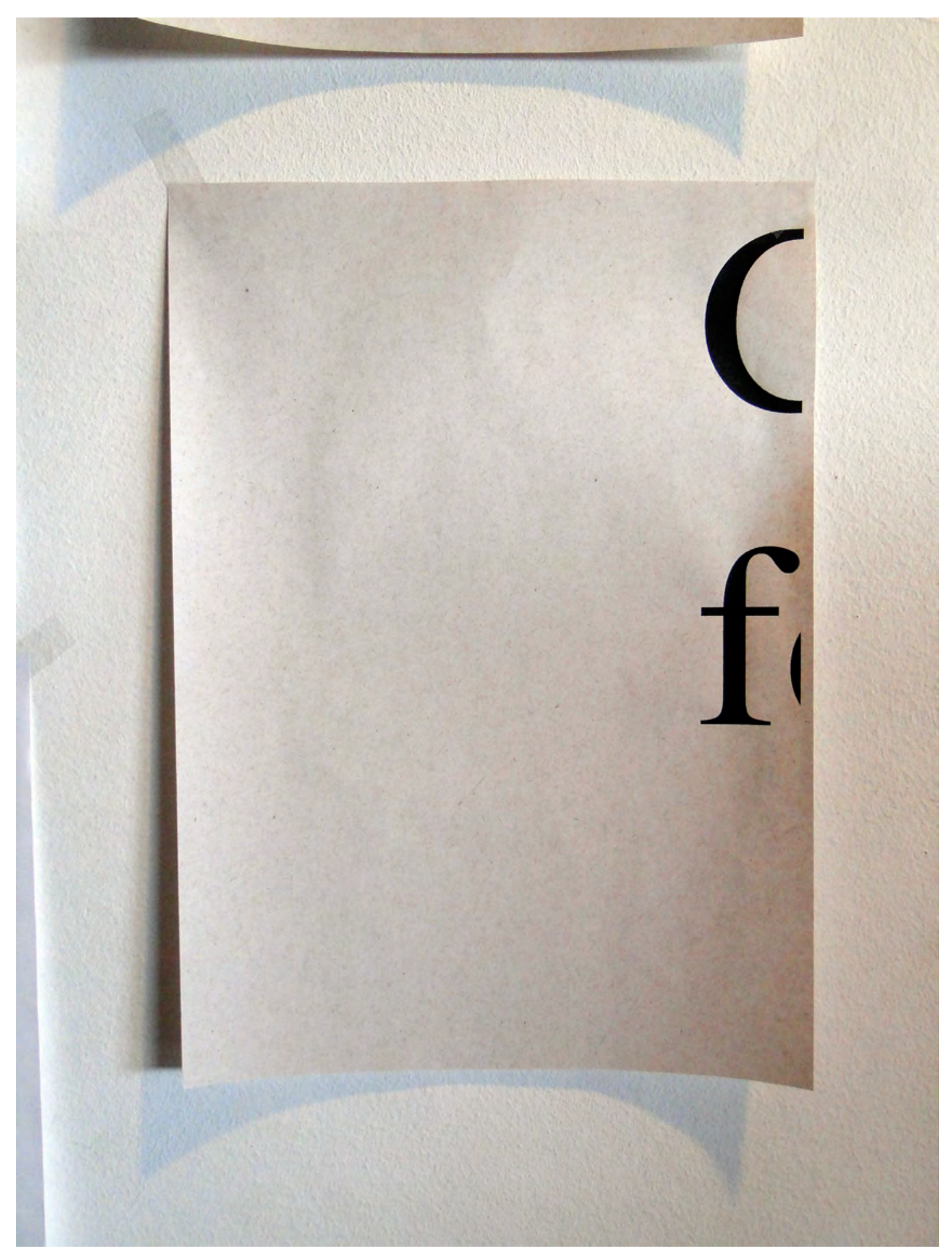




\section{CONCLUSÃO}

Uma conclusão não existe sem uma anterioridade. Escrevê-la é retomar os pontos principais do que já foi dito, a partir de uma leitura meticulosa do texto anterior. Toda conclusão é portanto referencialista. Enfrento assim novamente a relação problemática discutida ao longo da tese, aquela estabelecida entre o enunciado presente e o que lhe antecede. A conclusão acadêmica retoma os conteúdos de cada capítulo, transparente ao que foi trabalhado. Tal como uma tradução correta, explicita e dá clareza ao original, produzindo um solo seguro de comunicação entre o autor e o leitor. Mas o que acontece se esbarro, já na epígrafe da tese, nas linhas de Paul de Man, que desencoraja o tipo de leitura esclarecedora a qual me propunha?

\section{[...] todas as leituras incidem em erro, porque supõem a sua própria legibilidade ${ }^{121}$.}

A ideia de erro pode ser entendida como fracasso. Isso se houver um projeto triunfalista em mente, que pretenda decifrar completamente o seu objeto de leitura na busca de um texto que se entregue e deixe ver o seu conteúdo cristalino, límpido. Mas a concepção de erro também guarda uma proximidade com um outro sentido do verbo "errar": "desvio de bom caminho" ${ }^{122}$. É o erro como desvio que aproxima a epígrafe do conceito de desleitura, de Harold Bloom, ou clinamen. Reconecto assim com o que de fato gostaria

121 No original: All readings are in error, because they assume their own readabilty. Capturado em 08 nov. 2011. Online. Disponível em: <http://www.beaugrande.com/CRITBOOKDEMAN.htm>.

122 FERREIRA, Aurélio Buarque de Holanda. Novo Dicionário Aurélio da Lingua Portuguesa. 2 ed. Revista e ampliada. Rio de Janeiro: Nova Fronteira, 1986,p. 679. 


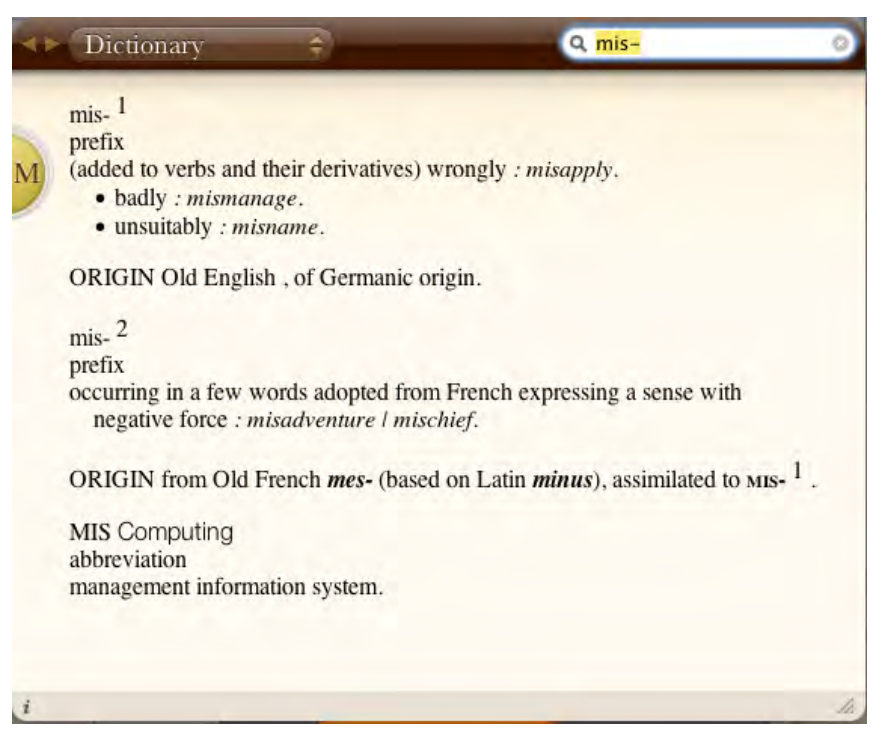

4. Dictionary $\quad$ Q misprision

mis.pri.sion ${ }^{1}$ |mispri zH ən| (also misprision of treason or felony) noun Law, chiefly historical

M the deliberate concealment of one's knowledge of a treasonable act or a felony.

ORIGIN late Middle English : from Old French mesprision 'error,' from mesprendre, from mes- 'wrongly' + prendre 'to take.

\section{mis.pri:sion ${ }^{2}$}

noun rare

erroneous judgment, esp. of the value or identity of something : he despised himself for his misprision.

ORIGIN late 16 th cent.: from MISPRIZE, influenced by MISPRISION ${ }^{1}$

\section{Referências do}

Oxford American Dictionaries, software disponível no MAC OSX versão 10.6.8.

123 BLOOM, Harold. E-book. The Anatomy of Influence: Literature as a way of life. Ed. Yale University, de fortalecer da tese na sua conclusão, a de uma leitura que não é submissa a um conteúdo dado a priori, mas sim uma leitura forte, capaz de realizar um desvio emancipador, incorporar o erro (a distância do original) e expandir o campo de problemas em questão. $O$ paradoxo posto a esta altura é que uma conclusão "correta" do que veio antes, nesta tese, é um "erro". A partir desta perspectiva também é possível rever a tradução de misreading por desleitura, conforme proposto por Arthur Nestrovski para traduzir o termo cunhado por Harold Bloom. O prefixo mis-, em inglês, está relacionado a algo que é feito de maneira errada [wrongly] ou mal feito [badly].

Já o prefixo "des”, em português, está associado a uma "ação contrária", ou "negação", como em "desfazer", contrário de "fazer". O prefixo no inglês mais próximo de "des-" seria un-. Uma tradução de desfazer para o inglês, por exemplo, seria undo. Assim, poderia inferir que ao traduzir o termo desleitura de volta para o inglês estaria mais próximo de unreading do que de misreading. Esta hipótese se confirma ao lermos o livro subsequente de Bloom, The Anatomy of Influence: Literature as a Way of Life, no qual o autor apresenta três palavras-chave para a compreensão de sua teoria: misprision, swerving e mistaking ${ }^{123}$. O termo misprision é traduzido por Nestrovski como desapropriação (ou expropriação). Dessa maneira, logra manter uma relação com o termo desleitura, por compartilhar o prefixo. No entanto, exclui novamente a relação com o "erro". Para misprision, uma das definições possíveis é "julgamento errôneo, esp. do valor ou identidade de algo". 
A segunda palavra, swerving encontra na palavra "desvio" o seu significado mais próximo. Por último, a palavra mistaking pode ser literalmente traduzida por "errar”, em português. Além, mistaking é composta por mis- e taking, verbo que pode ser traduzido por “pegar”, portanto, “pegar errado”. Conforme dito anteriormente, na introdução, as escolhas de Nestrovski têm o mérito de aproximar "desvio", desleitura e "desapropriação”, pelo compartilhamento do prefixo. No entanto, cabe a esta análise restituir as qualidades de "erro" e "julgamento errôneo", ligados aos conceitos elaborados por Bloom, que ficaram submersos nas escolhas feitas por Nestrovski.

\section{Desleituras}

A bobra a seguir foi escolhida para finalizar a tese por adensar e dar uma inclinação especial aos temas discutidos, tensionando as noções de leitura, autoria e tradução tratadas até agora. Foi projetada em função da minha participação no 320 Panorama da Arte Brasileira e também se enquadrava no convite feito a artistas-educadores para pensarem em um trabalho que interviesse no Setor Educativo da instituição, conforme descrito no capítulo Lina. O convite dos curadores a artistas-educadores estava alinhado a um contexto mais amplo de reposicionamento dos programas educativos no cenário da arte contemporânea internacional, cuja tendência tem sido atuar de maneira menos servil e mais propositiva. Alguns eventos de grande visibilidade onde isso fica evidente são a Manifesta 6 (2006), a Documenta de Kassel 12 (2007), ou, num exemplo mais próximo, a Bienal do Mercosul, com a criação da posição de "curador pedagógico" desde a sua sexta edição em $2007^{124}$. O que tem se buscado é um educativo que não seja apenas uma prestação de serviço, focado no atendimento ao público, mas um produtor de sentido incorporado ao projeto curatorial desde a sua concepção ${ }^{125}$. O movimento ganhou o nome de "virada

124 Para uma abordagem analítica dos casos citados, assim como uma contextualização mais ampla e crítica da chamada "virada educacional", ver HONORATO, Cayo. A formação do artista. 2011. Tese de Doutorado em Educação, FE-USP, São Paulo, 2011.

125 A incorporação do educativo pela curadoria não se deu desde o início do projeto no Panorama 2011, e 
educacional" [educational turn] na cena internacional. De acordo com Cayo Honorato: “A expressão 'virada educacional' foi recentemente objeto de uma antologia de artigos, precedida por uma quantidade de discussões, na qual em geral se denomina 'virada educacional' a incorporação da educação às práticas curatoriais, no sentido de uma reorientação paradigmática do interior das artes” (Honorato 2011: 112).

A relação de submissão do discurso educativo fica evidente na atividade que costuma ser o carro-chefe no atendimento ao público das instituições de arte brasileiras: as visitas guiadas ${ }^{126}$. Em geral, o discurso da mediação está a favor das obras (e da instituição) e presta um serviço de esclarecimento, informação e interpretação, facilitando o acesso aos conteúdos da obra e da mostra. Neste sentido, no que busca de satisfação (e geração) do público, corre o risco de espelhar uma lógica mercantil, na qual o espectador é tornado consumidor de seus serviços ${ }^{127}$. O discurso esclarecedor, e muitas vezes explicativo, com demasiada frequência vem em resposta a uma recepção ávida e carente de informação e formação em arte: sintoma difícil do sistema educacional frágil de nosso país. Neste cenário, não é incomum ouvirmos perguntas do gênero: "O que o artista quis dizer com essa obra?”; ou comentários como: "Não entendi este trabalho"; para as quais poderíamos escutar um mediador responder: "Essa obra fala de...”. São empenhos de leitura legítimos, naquilo que buscam de aproximação com um mundo muitas vezes tido como excessiva-

portanto não se assemelha exatamente aos exemplos dados. No entanto, o convite feito aos artistas-educadores, para que pensassem uma obra em conjunto com o educativo do museu, não deixou de tensionar e rever a costumeira posição dos artistas e do papel do setor, reverberando portanto na tendência mencionada. $126 \mathrm{Na}$ maioria das vezes, são visitas agendadas por escolas. De acordo com uma pesquisa feita na Bienal de São Paulo, por exemplo, cerca de 70\% do público visitante de uma bienal é composto por escolas agendadas e atendidas a partir de visitas guiadas (dados informados a partir de uma conversa informal com Denise Grinspum em 2008, que foi responsável pelo educativo da $27^{a}$ Bienal de São Paulo).

127 A relação entre espectador e consumidor, traçada a partir da relação que serviços educativos tem tido na produção de público e satisfação dos patrocinadores, me foi sugerida ao ler o artigo Arte-educação: para além do número de visitantes, de José Augusto Ribeiro. In: RIBEIRO, José Augusto. Arte-educação: para além do número de visitantes. Revista Número 2. Capturado em 26 nov. 2001. Online. Disponível em: $<$ http://www.forumpermanente.org/.rede/numero/rev-numero2/jose-augusto $>$. 
mente cifrado, opaco ou impenetrável; aquele da arte contemporânea ${ }^{128}$.

O foco do educativo do MAM também tem sido o atendimento de escolas com visitas agendadas. No entanto, seus integrantes evitam adjetivá-las como "guiadas". Há uma preocupação constante (e atual) de pensar em estratégias que sejam emancipadoras para esse público escolar, por mais que o formato e o tempo de duração das visitas ainda sejam bastante restritivos, evitando assim as "visitas palestra" (Honorato 2011: 100). Os mediadores, por exemplo, procuram não definir o percurso que será feito com os alunos a priori, deixando que o acaso e o interesse também possam ajudar na definição das rotas, já que não costuma ser possível abranger toda a exposição em uma visita apenas (duram menos de uma hora). Um outro privilégio desse setor do MAM é poder realizar atividades dentro do próprio espaço expositivo, onde, por exemplo, possuem um carrinho com cola, tesoura, papel, canetas e outros materiais. Seu caráter extrovertido favorece o entendimento do espaço expositivo enquanto um terreno vivo e aberto, contribuindo para o desgaste do peso simbólico que uma sala de museu de arte costuma carregar, enquanto um ambiente controlado, asséptico, silencioso e branco.

Participei do Panorama com duas obras: Café Educativo (2007) e Desleituras (2011). O Café Educativo consistiu na instalação de uma ambiente de café no espaço expositivo, cuja particularidade era ter o seu atendimento feito por um mediador do educativo, ao invés de um garçom. Servia também como um espaço de mediação espontânea, no qual o público podia ler revistas, jornais, assistir filmes e acessar a internet. A bobra que mais se relaciona a esta pesquisa é Desleituras ${ }^{129}$. Foi produzida durante a fase da escrita da tese de doutorado, e portanto herdou parte da sua problemática, o que justifica o seu título. Foi pensada a partir de uma série de obras de minha trajetória recente, a qual consiste em híbridos de palavras escritas em tapetes de boas-vindas feitos de borracha,

128 Os apontamentos feitos aqui partem de observações pessoais baseadas, principalmente, na minha experiência como educador e coordenador do setor educativo do Paço das Artes, São Paulo, 2007, quando também tive a oportunidade de participar da cena educativa local.

129 Homenagem ao conceito de misreading de Harold Bloom e à tradução de Arthur Nestrovski do termo: desleitura. 
realizados em 2011, produzidas independentemente de um contexto específico. O texto contido é sempre construído a partir de misturas de palavras distintas que sugerem novas possibilidades de leitura e sentido (i.e: FELISO, EULOGIO, FOMILIAR e DEUSEJO).

O desdobramento feito para o $32^{\circ}$ Panorama, além do contexto específico do

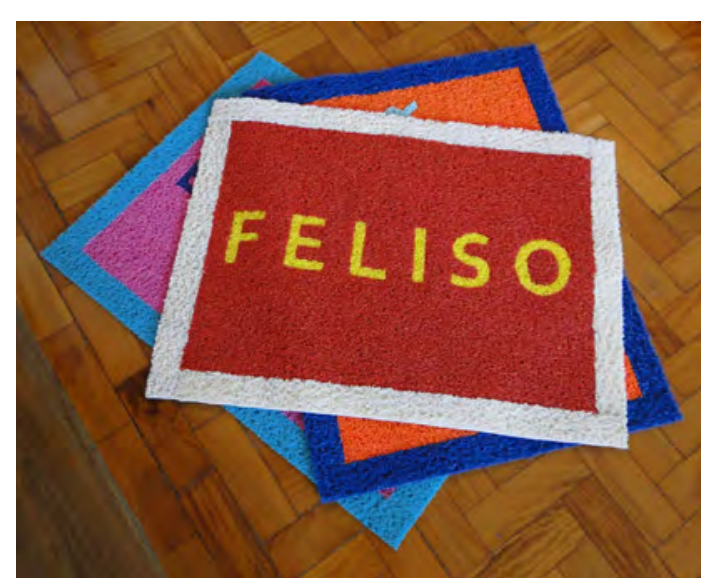
convite dos curadores para atuar junto ao setor educativo, agregou novas perspectivas para a série de obras mencionada. O objeto “tapete de boas-vindas” por si só já carrega uma referência de mediação entre ambientes. Costumam ser usados em espaços fronteiriços entre um dentro e um fora, marcando uma passagem geralmente sinalizada por um texto amigável ou imagem informativa do território que estamos prestes a entrar. Seu uso como dispositivo de mediação nas visitas não seria portanto estranho a sua natureza funcional e simbólica. No entanto, a sua relação com as palavras inventadas, que até então haviam sido pensadas de maneira mais ou menos espontânea e sem uma referência externa imediata, precisaria ser reelaborada a partir das especificidades da situação colocada.

O procedimento de invenção das palavras para os taDEUSEJO

130 A pesquisa contou com a colaboração da curadora Cecília Bedê. 
bre as obras, produzi um outro para a entrada do museu. Este, em uma dimensão amplia$\mathrm{da}(2 \times 3 \mathrm{~m})$, traduzia o conceito da própria exposição, interpretando o texto curatorial.
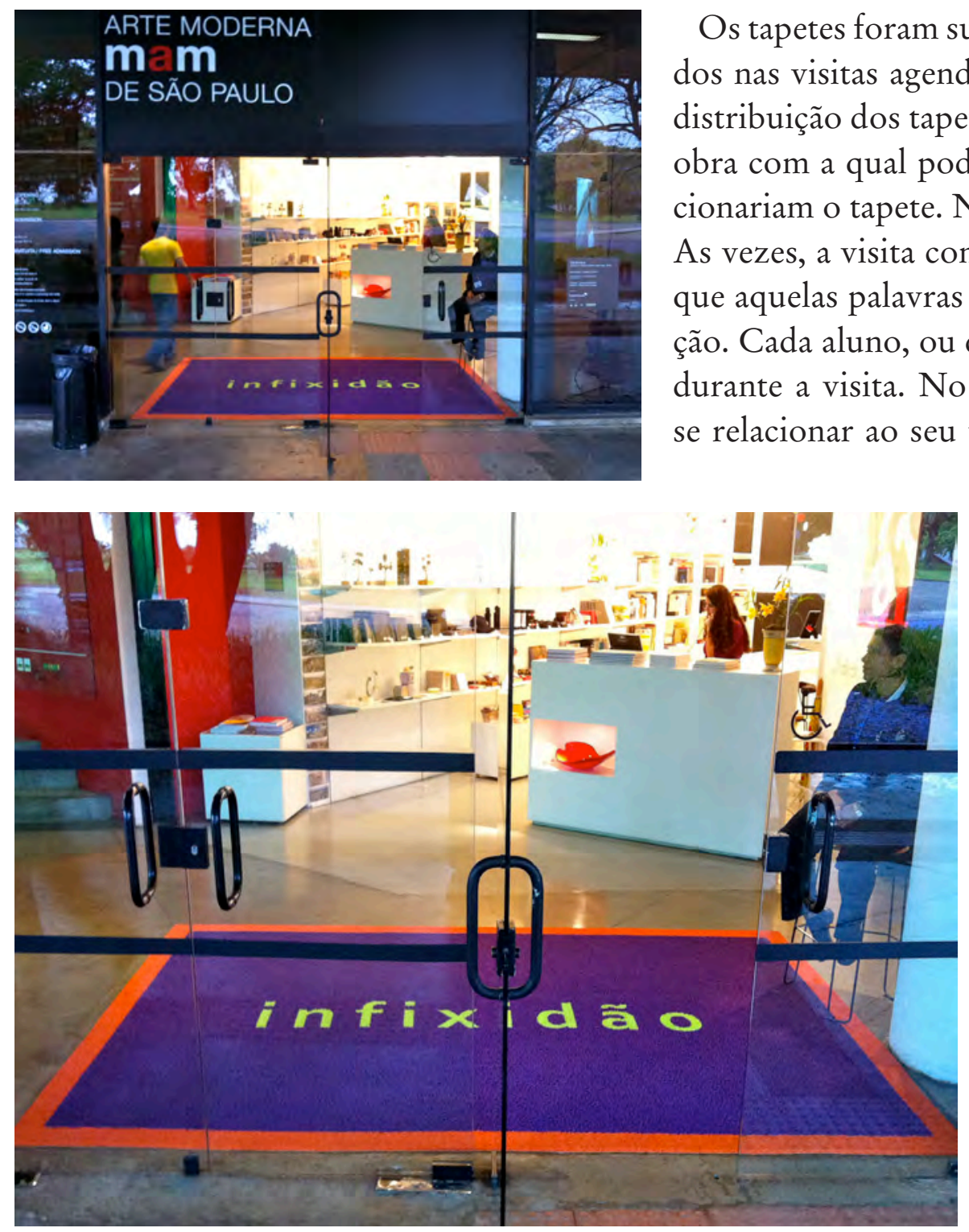

Os tapetes foram sugeridos como dispositivos de mediação para serem usados nas visitas agendadas com escolas. A atividade que propus consistia na distribuição dos tapetes para os alunos em visita, que então escolheriam uma obra com a qual poderiam traçar alguma relação com a palavra, onde posicionariam o tapete. Na prática, os tapetes foram usados de múltiplas formas. As vezes, a visita começava por eles, quando os alunos eram informados de que aquelas palavras haviam sido pensadas a partir dos trabalhos da exposição. Cada aluno, ou dupla, escolhia então um tapete, o enrolava, e carregava durante a visita. No momento em que encontrasse uma obra que poderia se relacionar ao seu tapete, este era disposto. Em uma outra abordagem, o mediador realizava uma visita com o grupo e, ao final, liam os tapetes conjuntamente e elegiam então a obra a qual se destinaria. A origem de cada tapete, ou seja, a obra a partir da qual criei cada um, jamais foi revelada. A omissão se deu para garantir a fluidez do texto, assim como evitar a ideia de "certo" ou "errado" nas relações, cultivando uma liberdade associativa.

Em todas as situações descritas, os tapetes funcionaram como disparadores de conversas com os grupos. A ambiguidade das palavras trabalhava a favor de um discurso aberto, multivocal, sem um ponto de chegada definido. Neste sentido, distanciavam-se de um discurso explicativo ou esclarecedor, atuando mais como provocadores do que mediadores de um conteúdo dado a priori. Na sua proposição de construir um texto sobre as obras da exposição - analisando-as 
e pesquisando-as - as palavras pensadas para os tapetes se aproximavam da intenção de um texto crítico sobre a exposição. Ao mesmo tempo, distanciavam-se de um texto do gênero ao manifestar uma dose de subversão da linguagem, que as aproximaria mais do texto poético ou das próprias obras. Habitavam assim um território ambíguo, em trânsito entre obra, discurso crítico e dispositivo de mediação. A cada nova visita, os tapetes transitavam pela exposição e estabeleciam novos laços e disjunções com as obras e entre si, num fluir contínuo e errático pelo espaço. Houveram também usos inusitados, como o acúmulo de vários tapetes em uma obra somente ou um tapete que, ao invés de se referir a uma obra apenas, traduzia uma região com duas ou mais obras.

Desleituras apresenta alguns desvios em relação às hobras descritas nos capítulos. O primeiro deles diz respeito às figuras de anterioridade. As hobras-originais e os artistas tratados anteriormente têm um lastro histórico e um legado já sistematizado pela crítica, diferente da maioria dos artistas no $32^{\circ}$ Panorama. Assim, a pesquisa realizada sobre as hobras nos capítulos permitiu a construção de um olhar decantado no tempo, ao qual se agregam diversas leituras oriundas de outros autores e posicionamentos. As obras do $32^{\circ}$ Panorama são, na sua maioria, muito recentes. O olhar analítico sobre os trabalhos expostos não possuía portanto uma espessura temporal, com a exceção de alguns artistas que eu já havia acompanhado anteriormente ${ }^{131}$. Outra diferença importante é a relação entre o original e a tradução. Ao ocultar o original ao qual se refere cada palavra, cria-se um terreno de indeterminação, no qual o original passa a ser potencialmente qualquer um que se encontra no campo tradutório. O que se produz assim é uma área onde todos são suspeitos, onde a identificação - que pela própria natureza do jogo é instável - reside no leitor, e não na intenção de um autor que prescreve a resposta, o lugar onde se deveria chegar. Finalmente, os sucos gástricos e metabólicos presentes em Desleituras não digeriam somente às obras e artistas presentes no $32^{\circ}$ Panorama, mas o próprio discurso mediador e sua pretensa transparência comunicativa, as mesmas velhas e gastas palavras. Se o outro está em constante invenção, a língua que conta a sua história é inverção.

131 Quando integrei o Grupo de Crítica do Centro Cultural São Paulo (2008-2010), acompanhei e escrevi sobre dois dos artistas que também integravam o grupo do $32^{\circ}$ Panorama: Rodrigo Bivar e Amanda Melo. 


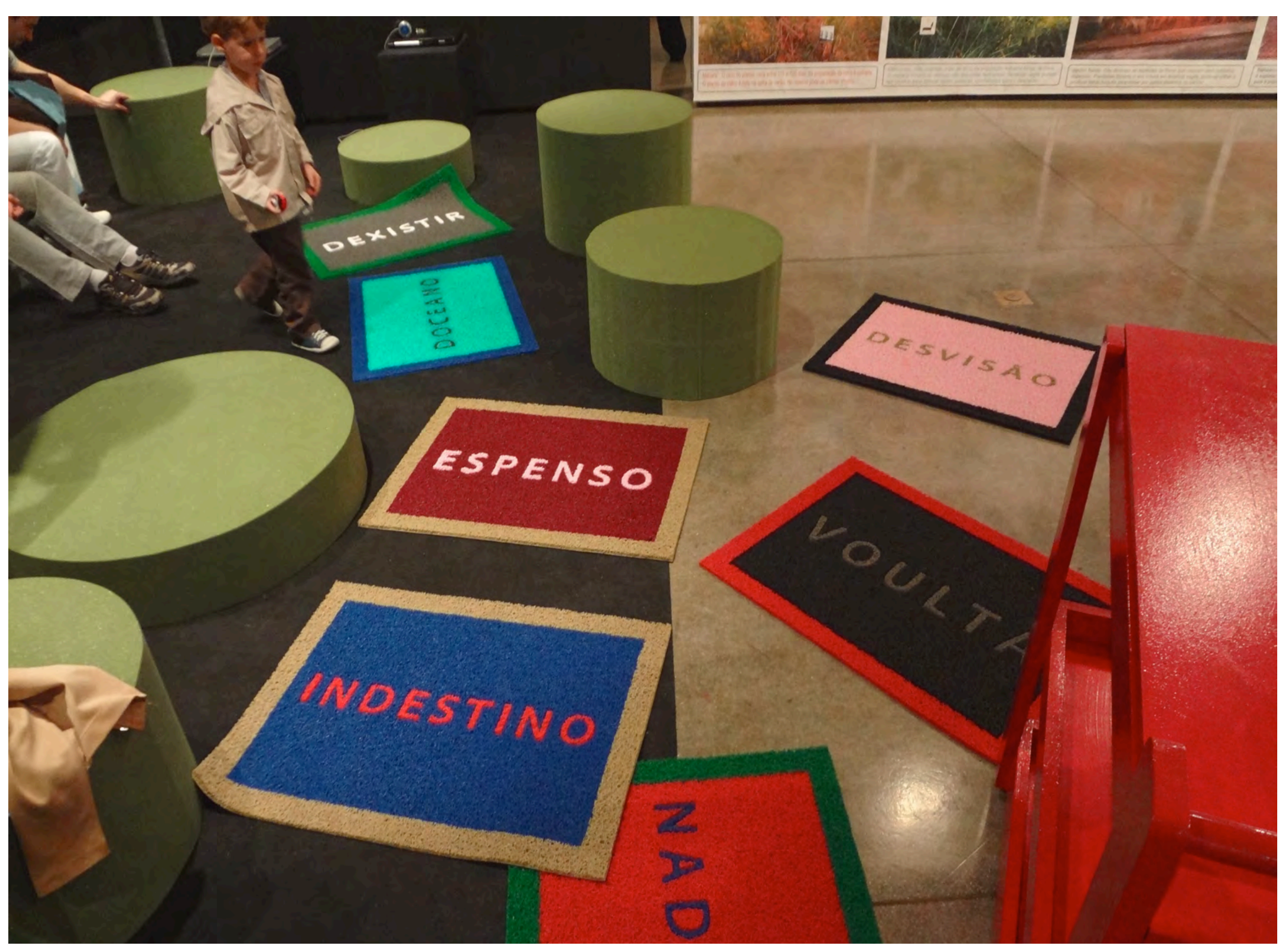



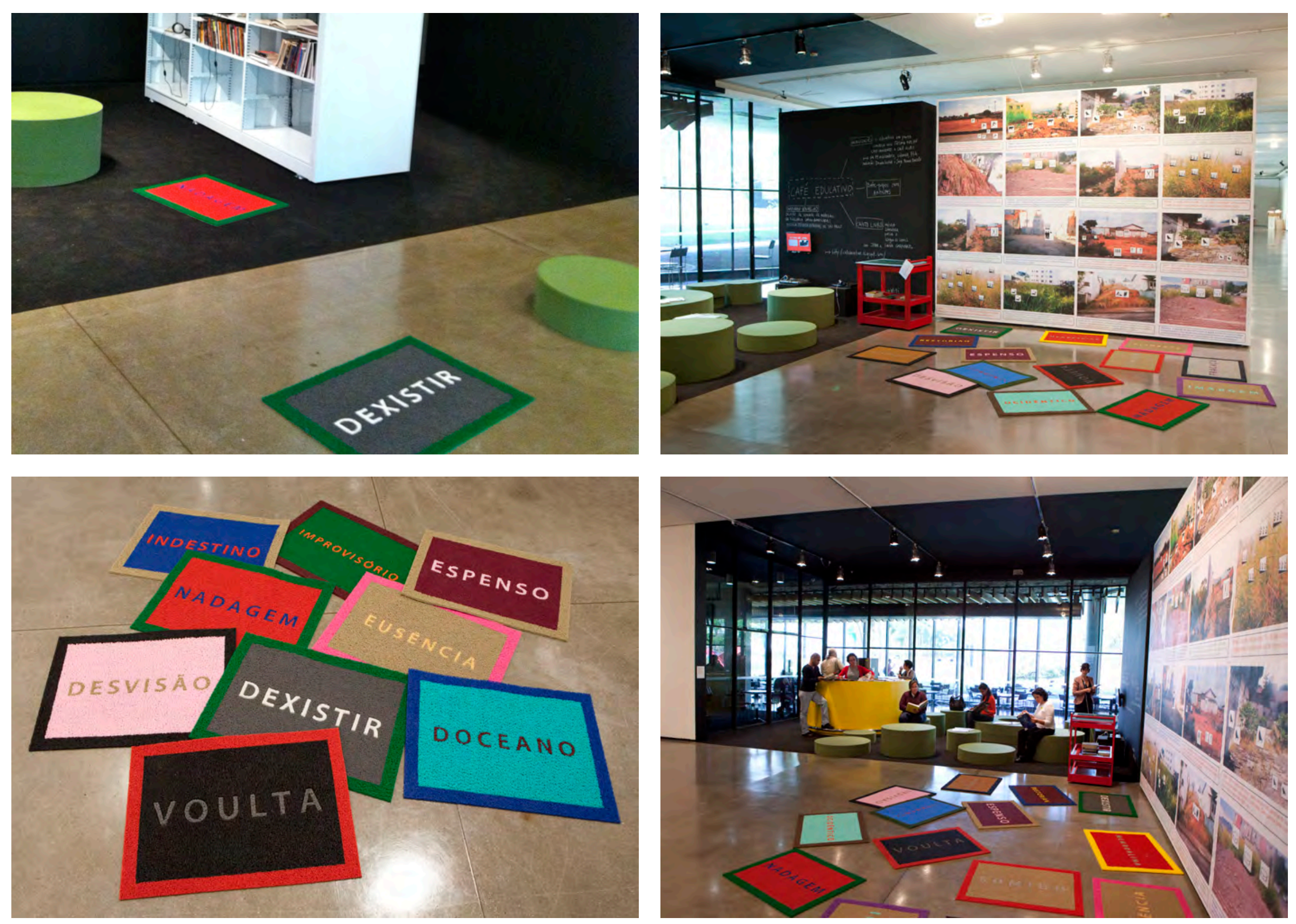


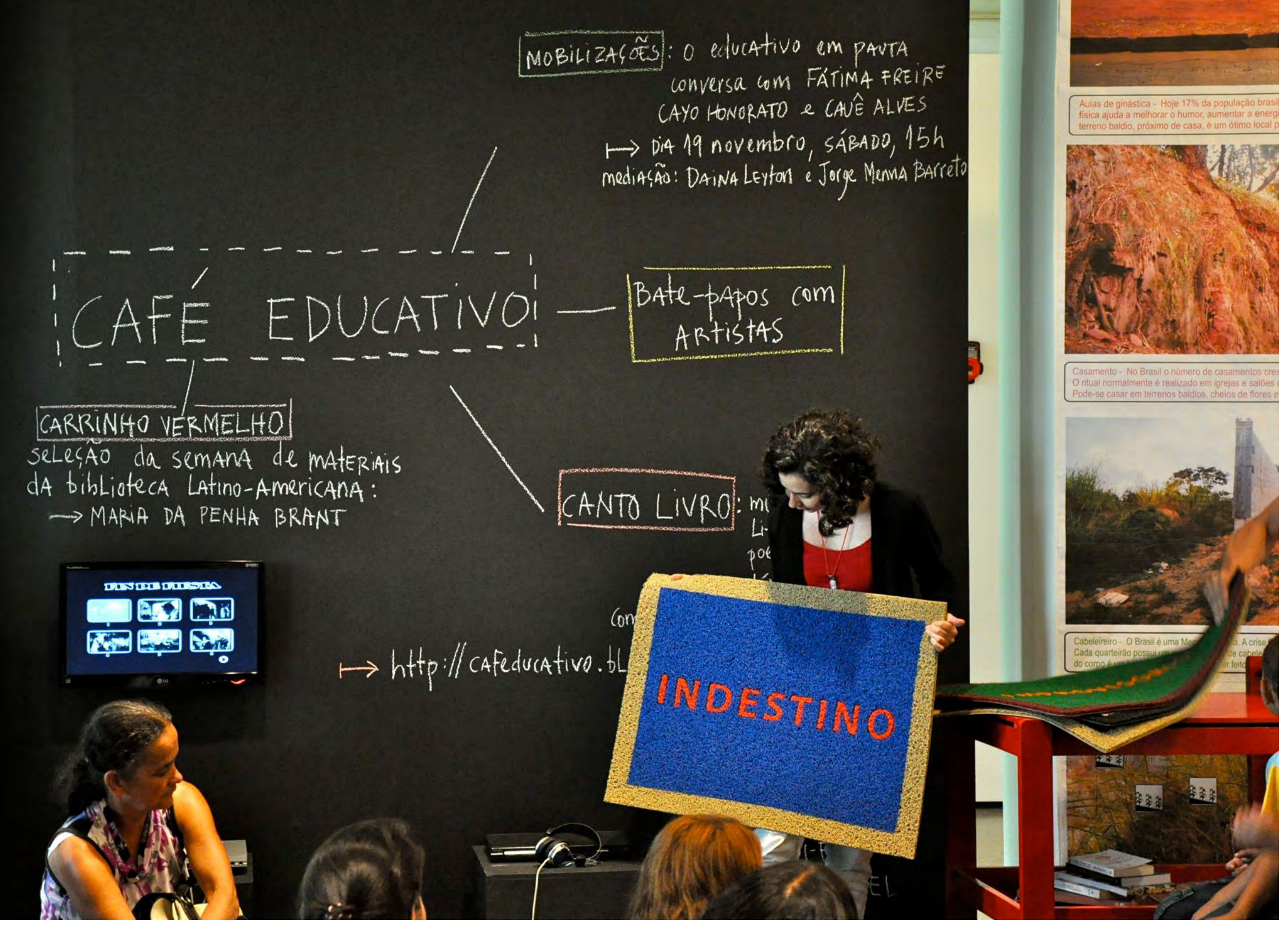




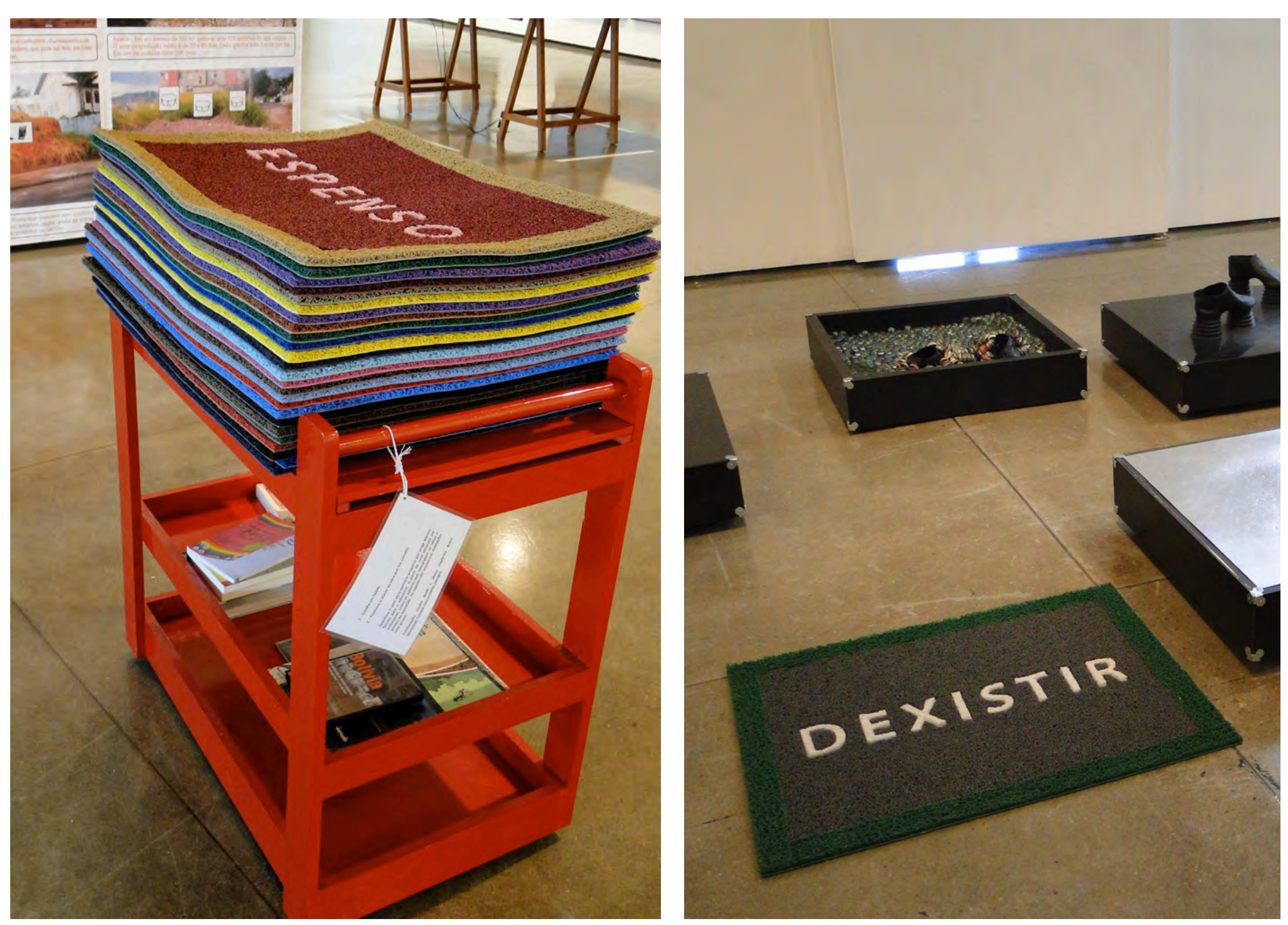




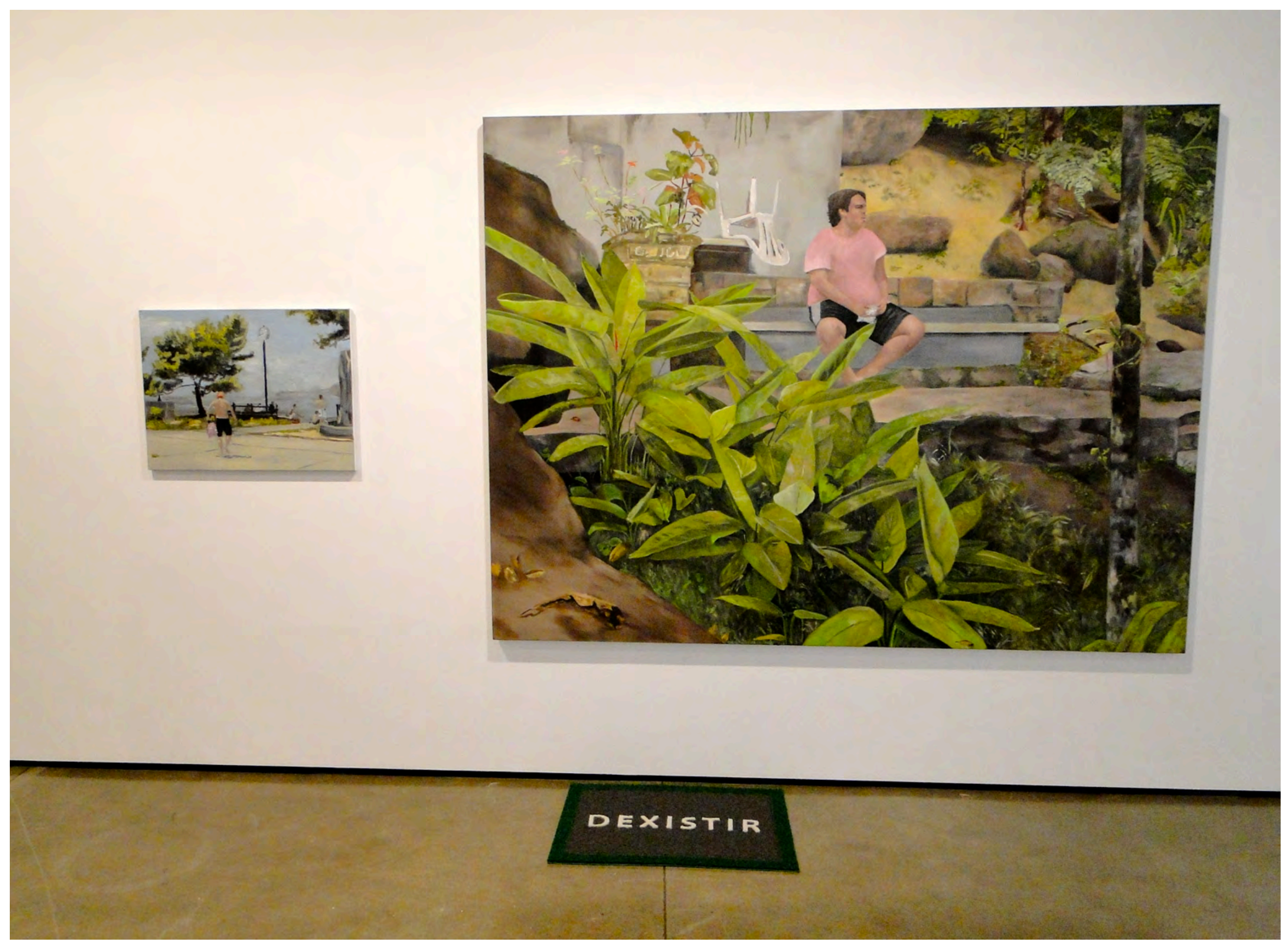



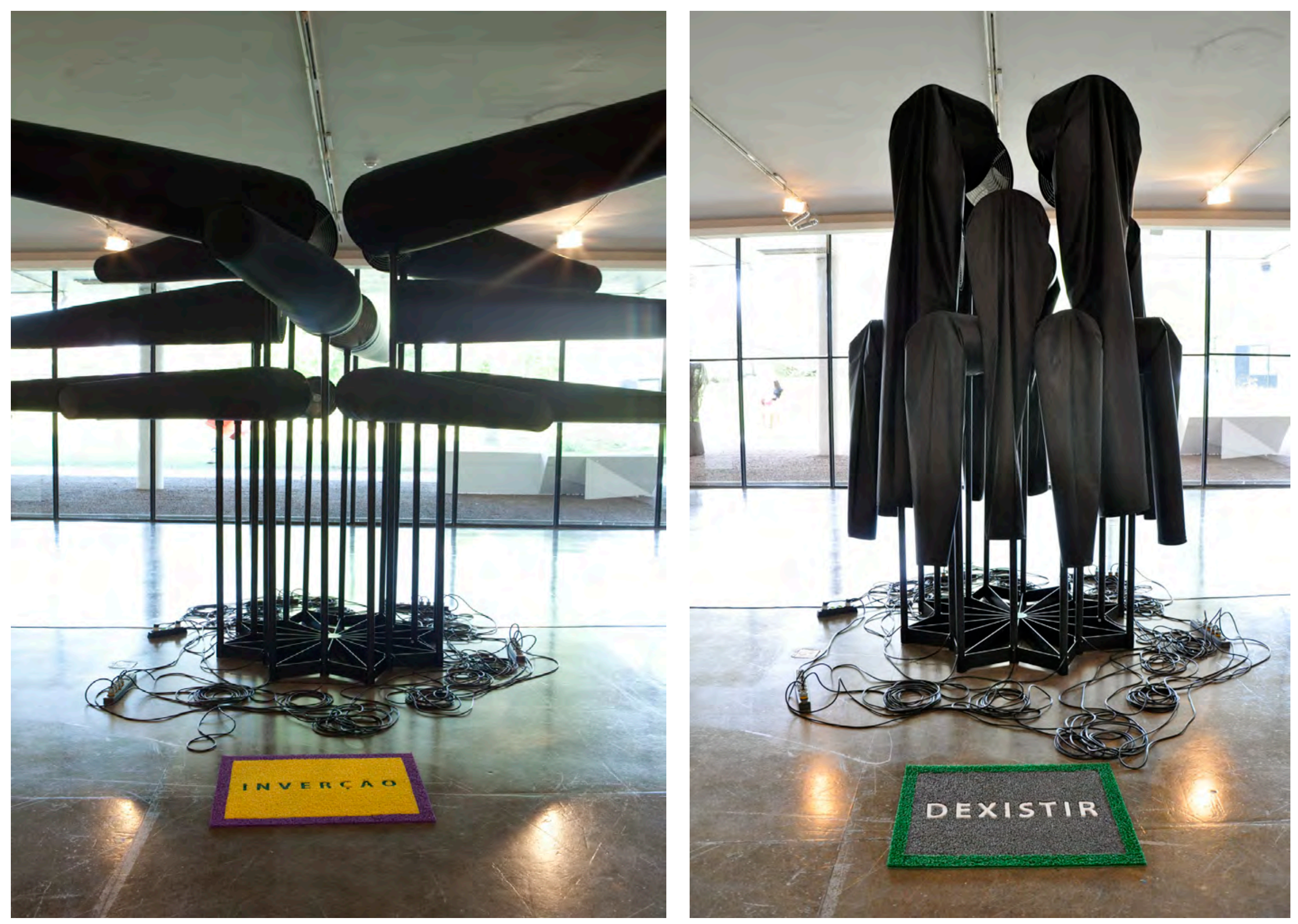


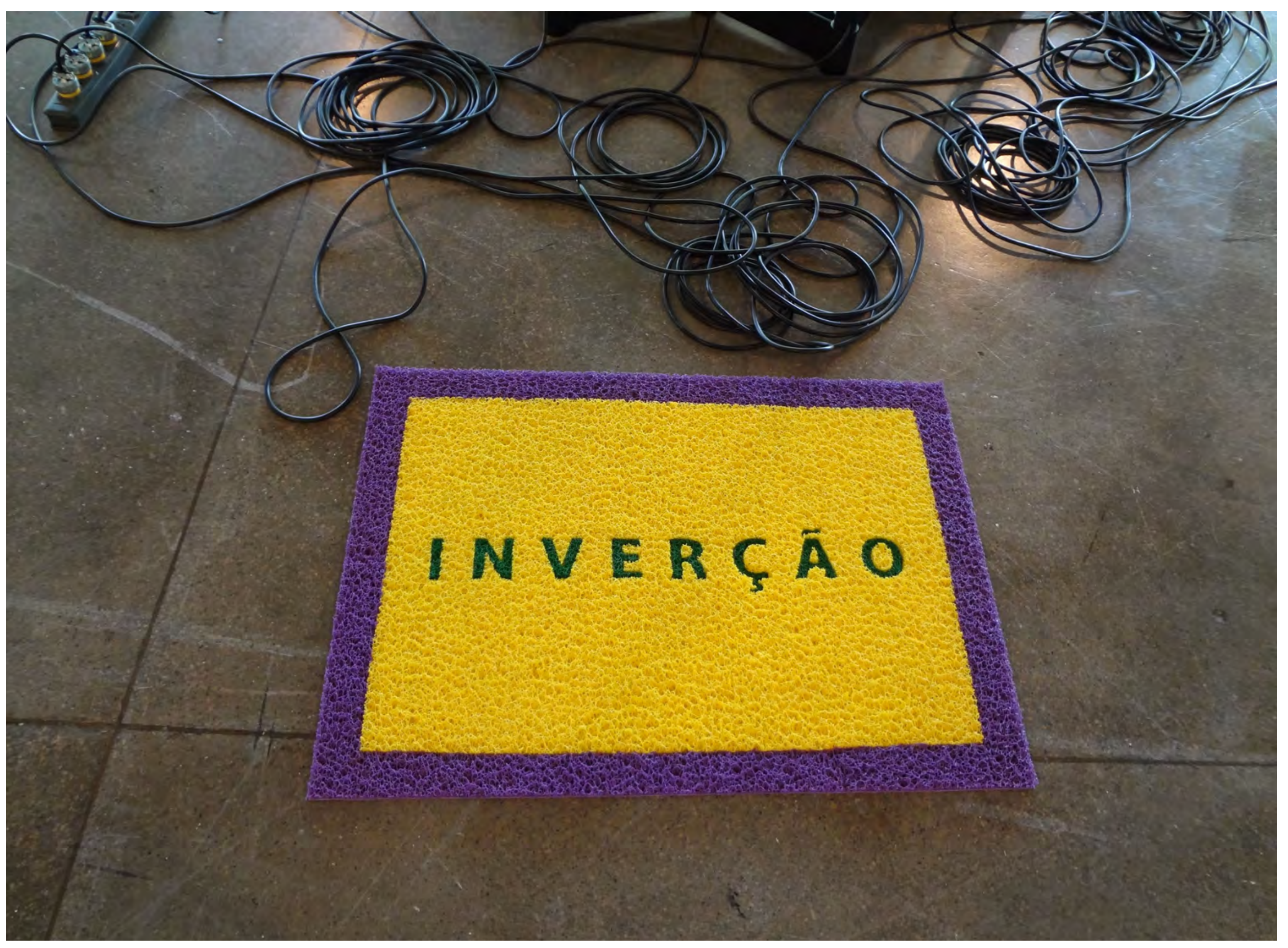




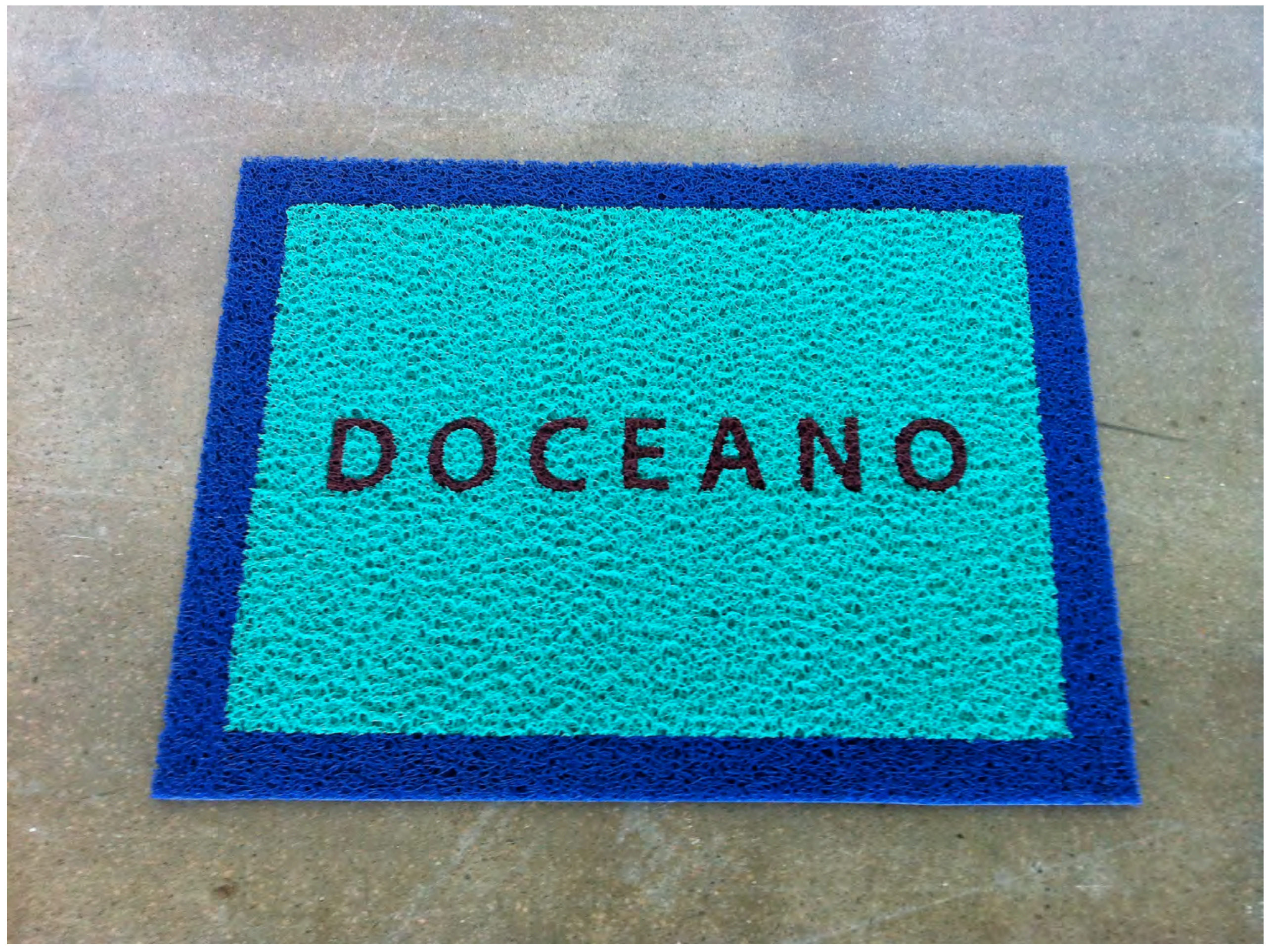



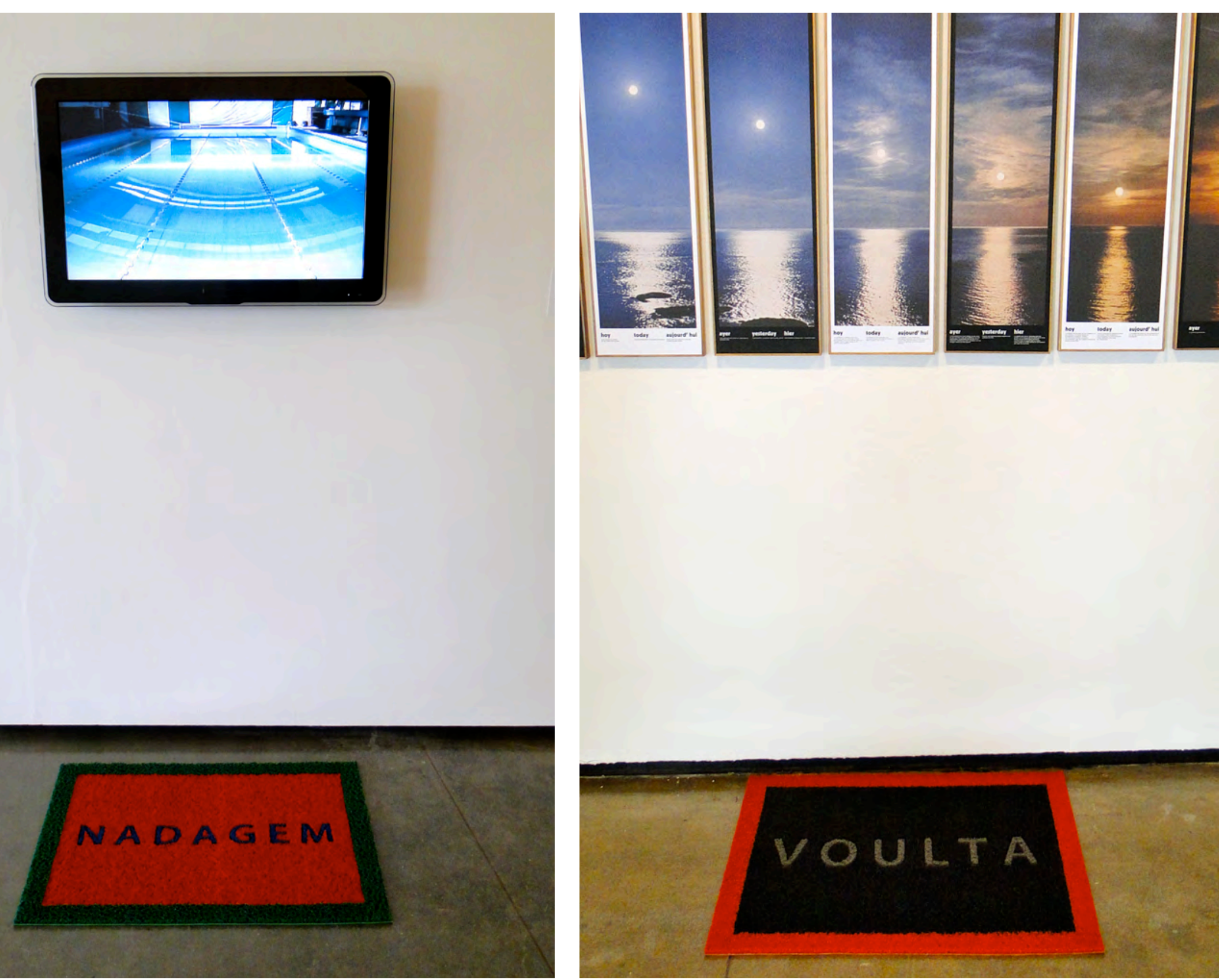

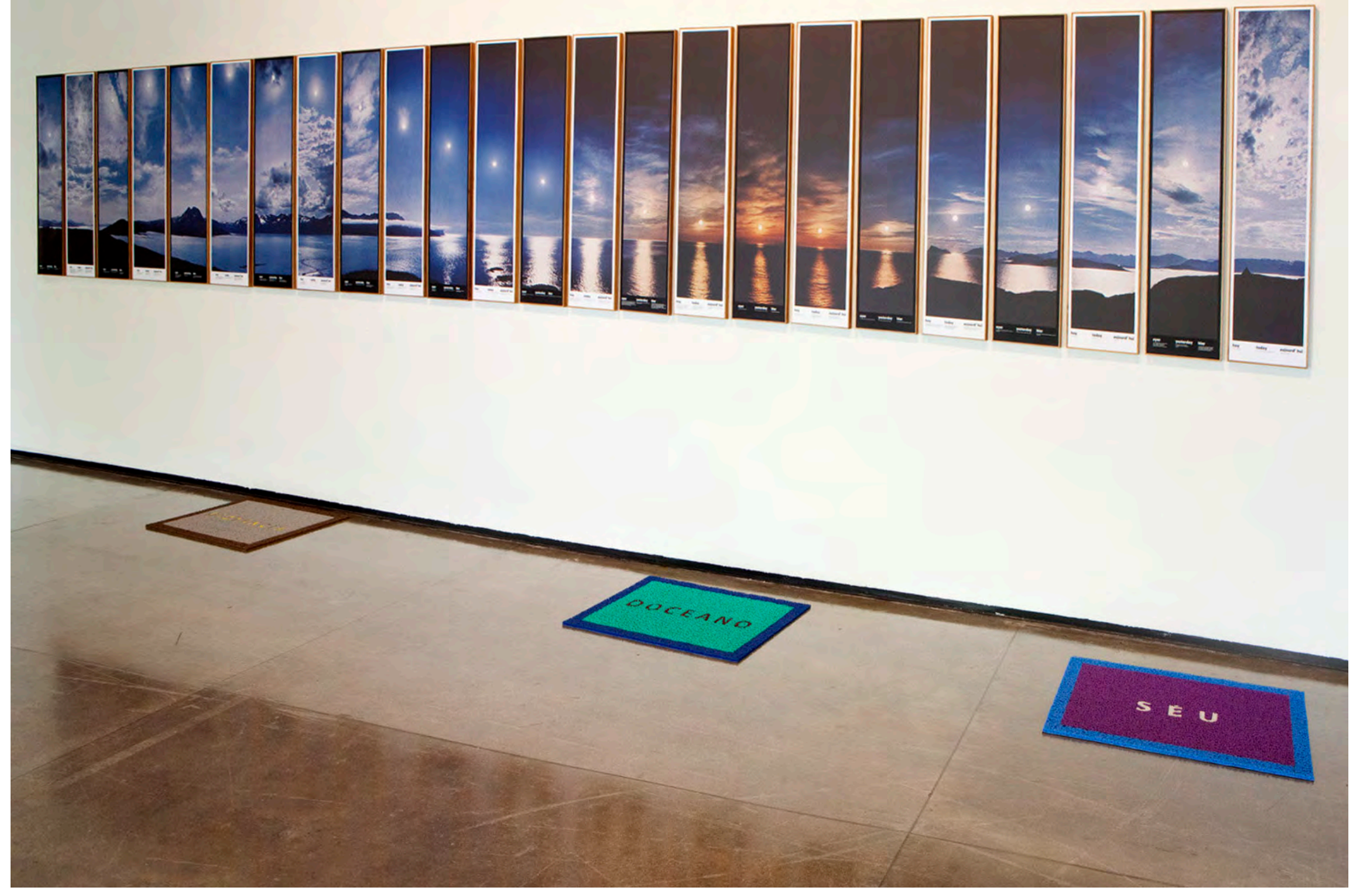


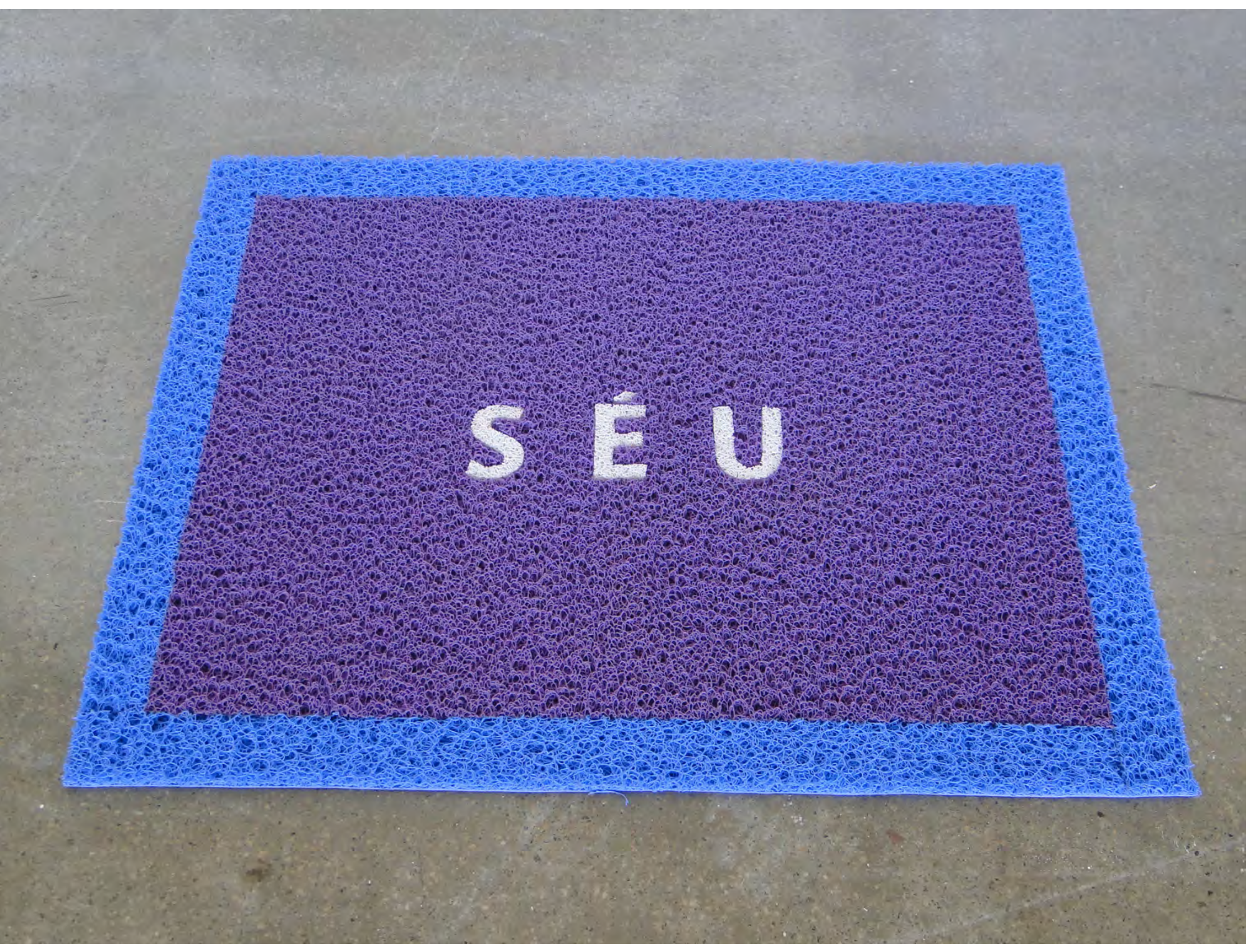



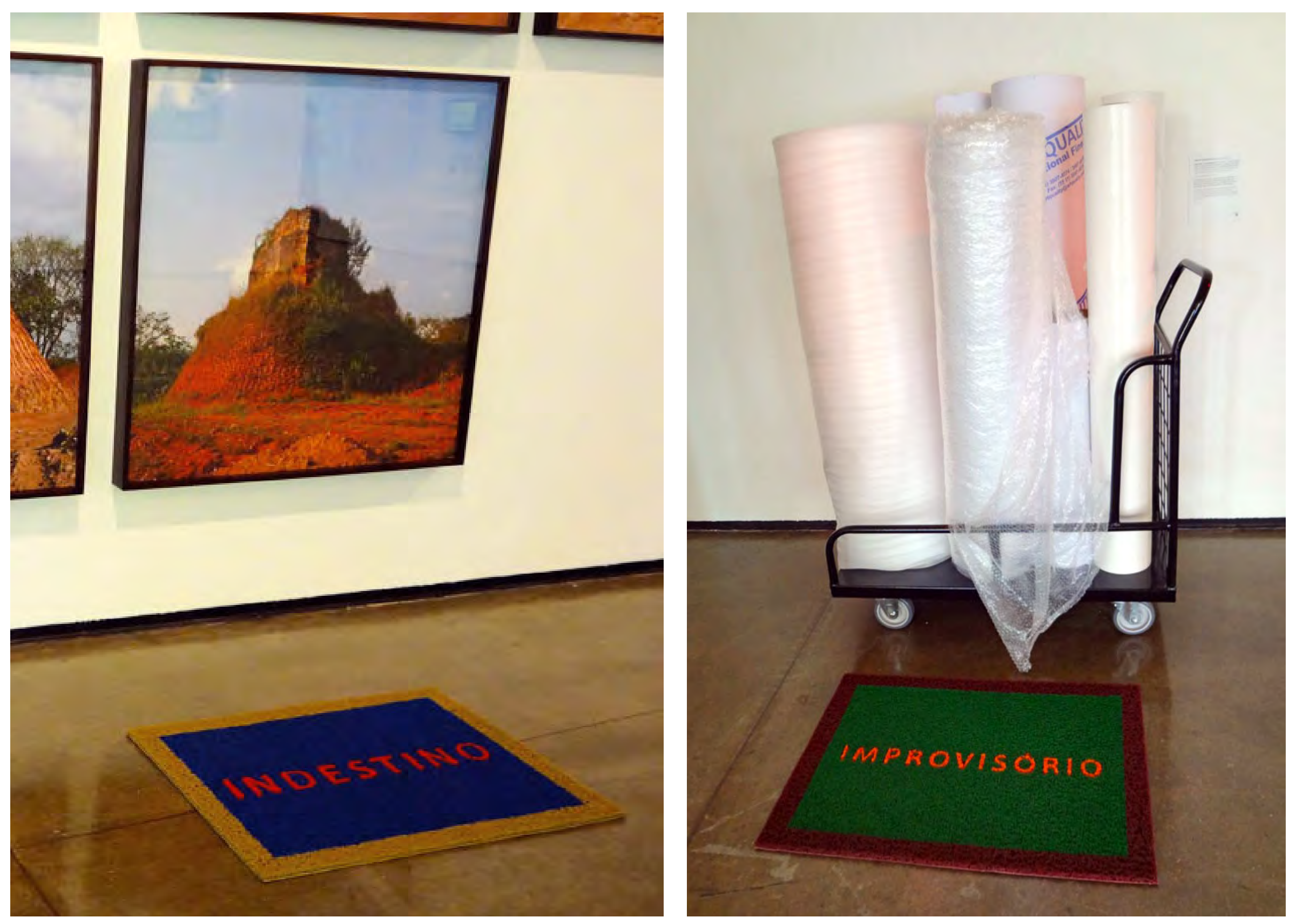



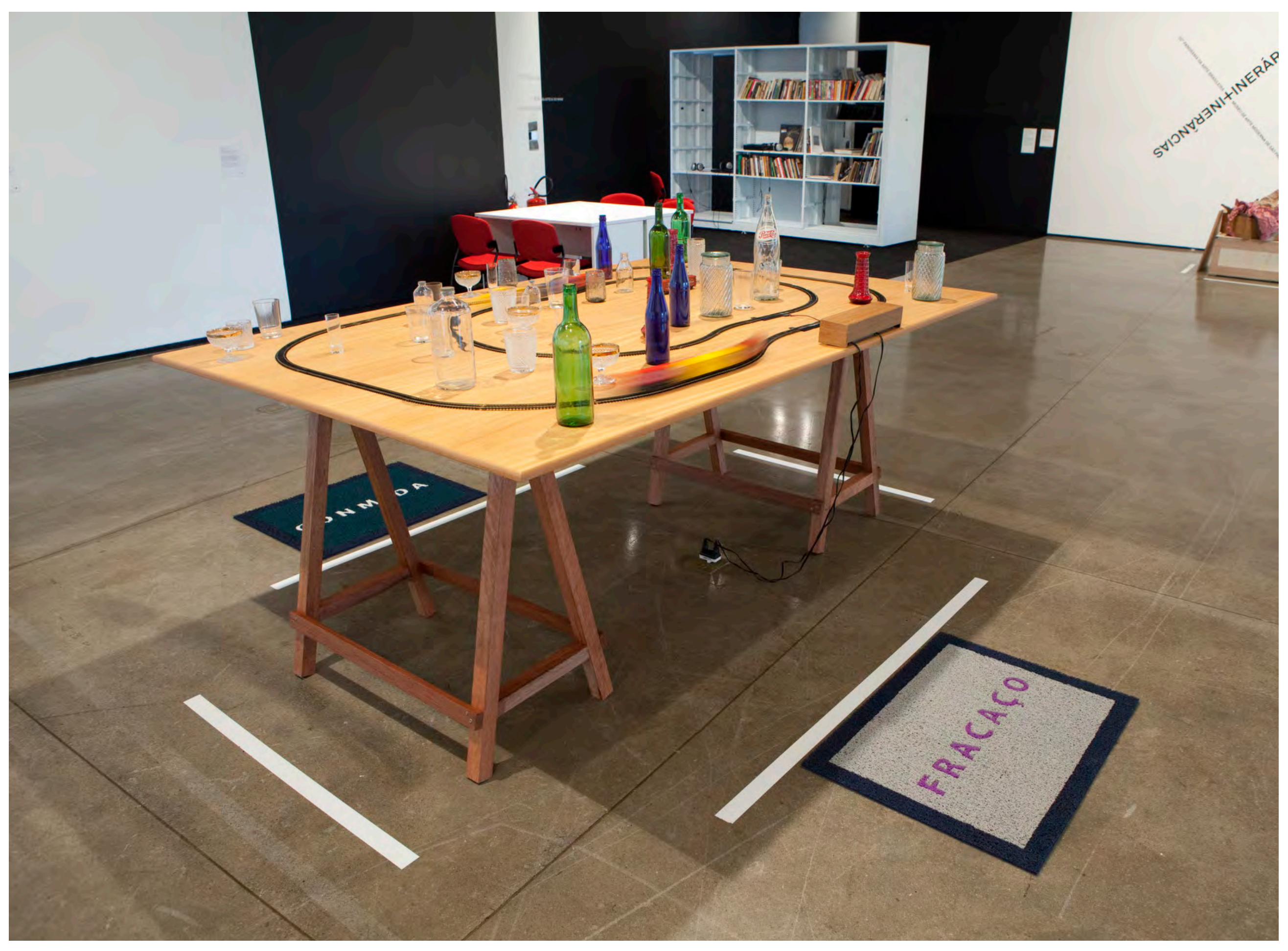



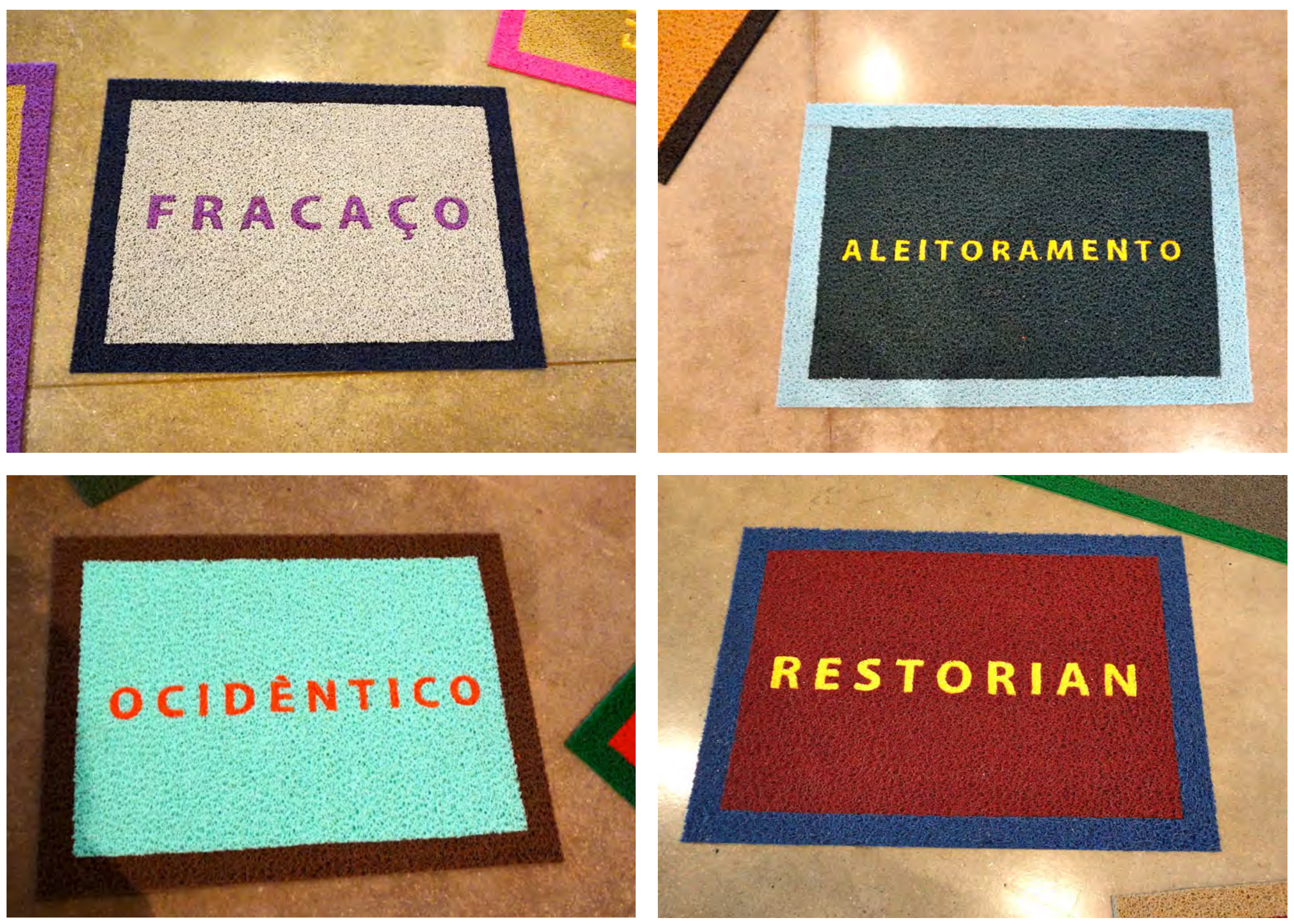
$M E M: R A L I N A$ 

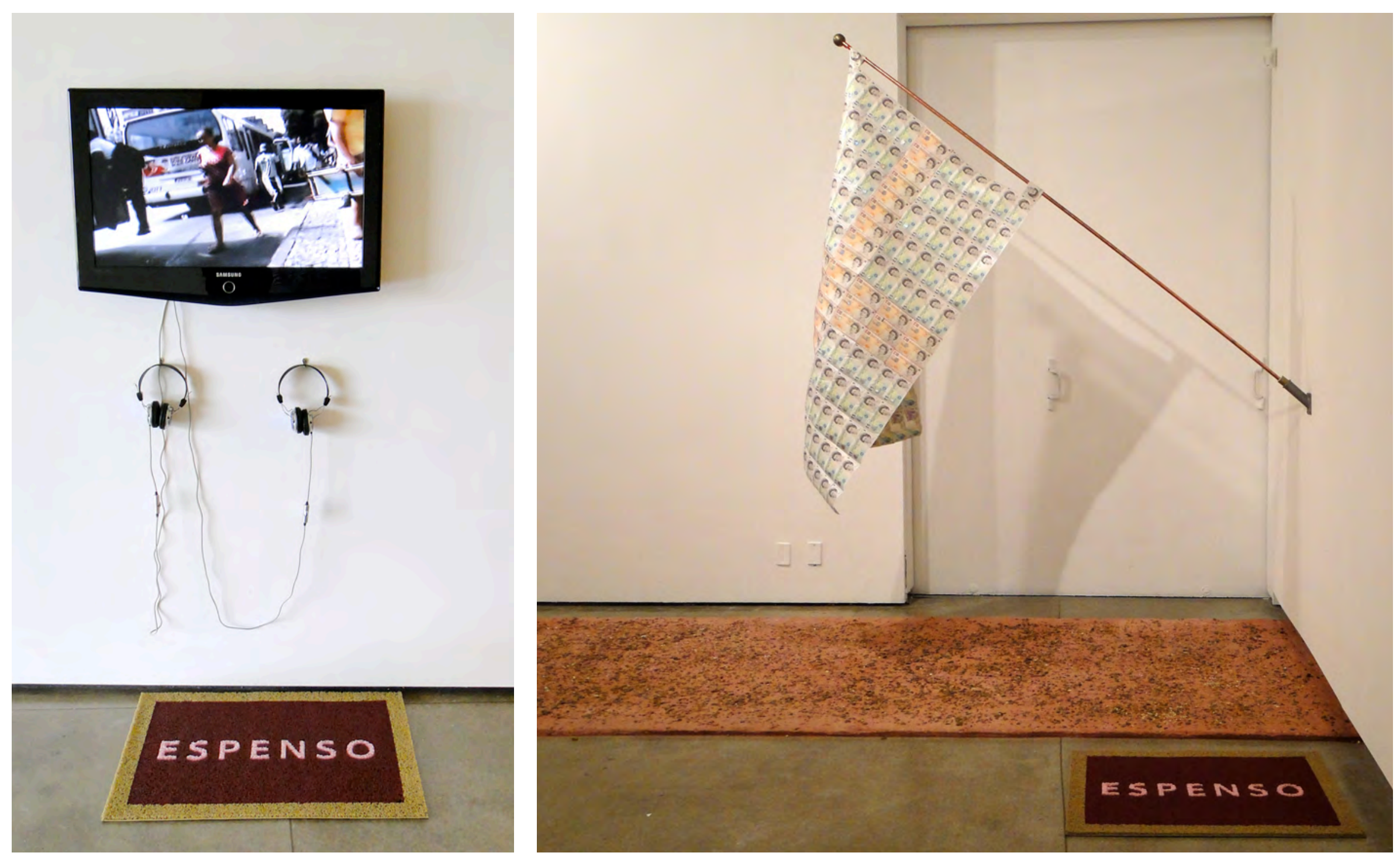



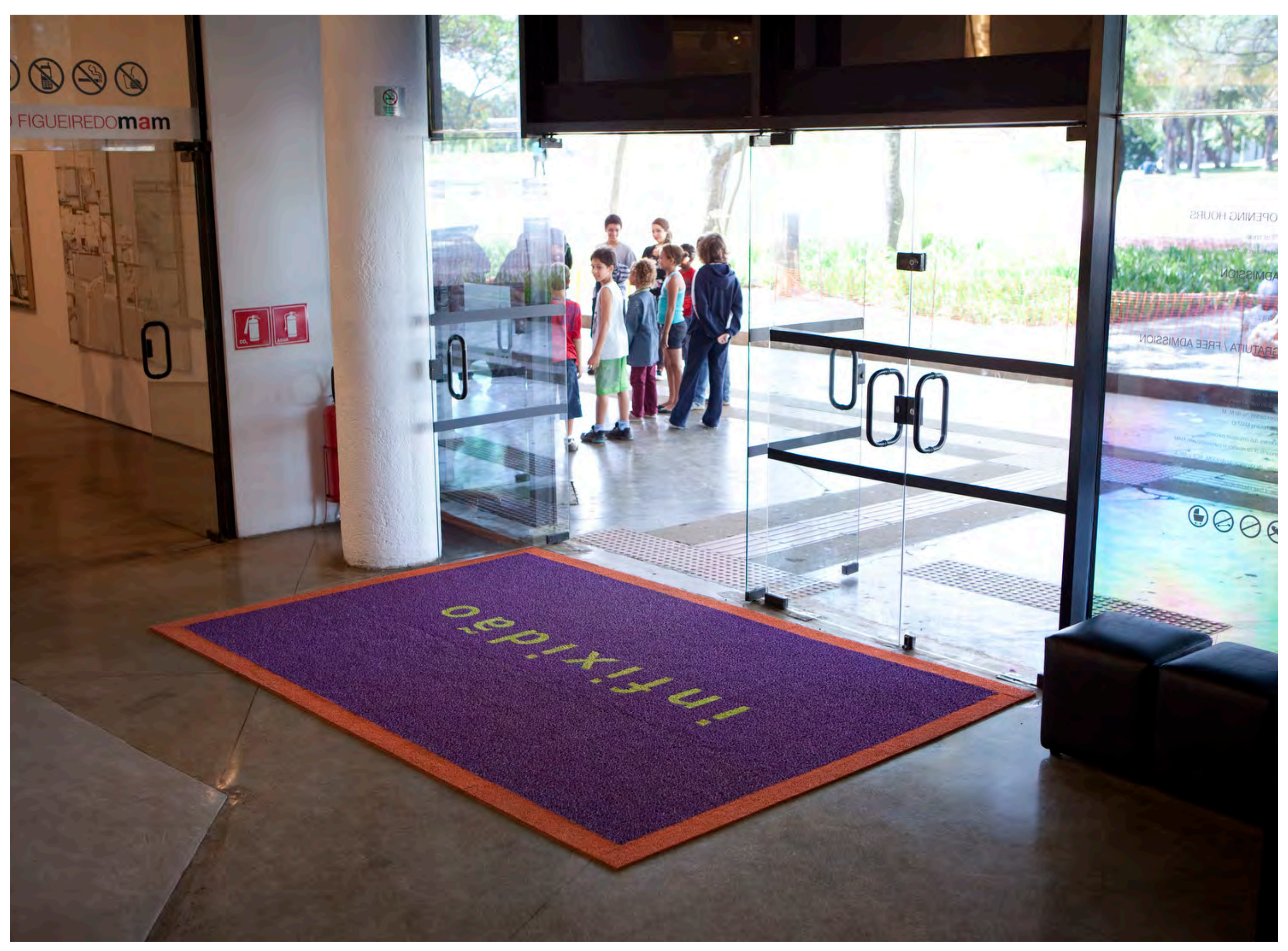




\section{ÍNDICE REMISSIVO DE IMAGENS:}

p.9 Caro_eitor(fotografia digital), 2010, Jorge Menna Barreto (continua na página 126).

p.13 Foto da página 10, prefácio do livro As Magias: poemas mudados para o português de Herberto Helder (2010).

p.40 Foto da página 47 do livro João Cabral: a poesia do menos, de Antonio Carlos Secchin (1985).

p.54 Foto da epígrafe do livro Doze nós numa corda: poemas mudados para o português, de Helberto Helder (1997). Em versão minha para o português: "Entender: traduzir. E tudo é tradução em todos os níveis, em todas as direções / O mal é o ritmo dos outros / Falamos aos decaptiados, os decapitados respondem em 'onolof'”.

p.67 Foto da página 86 do livro Between Artists de Tim Rollins (1996). Em português: “Tim, eu devo dizer que se não tivesse lido Walter Benjamin, Fanon, Althusser, Barthes, Foucault, Borges, Mattelart e outros, talvez eu não tivesse conseguido fazer algumas obras, chegar a certos posicionamentos" (tradução minha).

p.75 Foto da página 13 do livro João Cabral: a poesia do menos, de Antonio Carlos Secchin (1985).

p.88 Foto da página 95 do livro Jac Leirner in conversation with Adele Nelson (2011).

p.101-102 Foto das páginas 21 e 22 de Heráclito e seu (dis)curso, de Donaldo Schüler (2000). 
p.138 Tapetes diante da obra Sapatos sonoros, 2011, de Romano. 32o Panorama da Arte Brasileira, MAM-SP, 2011 (dir.).

p.139 Tapetes diante das pinturas de Rodrigo Bivar (O bravo (segunda versão, $2011 \mathrm{e}$ Umidade Relativa, 2011). 32o Panorama da Arte Brasileira, MAM-SP, 2011.

p.140 Tapetes diante da obra Crisis de credibilidad, 2010-1, de Hector Zamorra. 320 Panorama da Arte Brasileira, MAM-SP, 2011.

p.143 Tapetes diante das obras Planos móveis, 2007, de Sara Ramo (esq.) e HoyAyer, 2011, de Jonathas Andrade. 32o Panorama da Arte Brasileira, MAM-SP, 2011.

p.144 Tapetes diante da obra HoyAyer, 2011, de Jonathas Andrade. 32o Panorama da Arte Brasileira, MAM-SP, 2011.

p.146 Tapetes diante das obras Arquipélago \#2, 2008-11, de Pedro Motta (esq.) e Inacabado / em andamento, 2011, de Rodrigo Matheus.

p.148 Tapetes diante da obra Partitura, 2010-11, de Cadu.

p.151 Tapetes diante das obras Degrau, 2009, do grupo GIA e Jack Pound Financial Art Project (topografia suada de Londres parte 1), 2008-9, de Lourival Cuquinha (dir.). 


\section{REFERÊNCIAS}

\section{Livros}

ATHAYDE, Felix de. Ideias Fixas de João Cabral de Melo Neto. Rio de Janeiro: Nova Fronteira, 1998.

BASBAUM, Ricardo (org.) Arte Contemporânea Brasileira. Rio de Janeiro: Rios Ambiciosos, 2001.

. Além da pureza visual. Porto Alegre: Editora Zouk, 2007.

BENJAMIN, Walter. Sobre o conceito de história. In: BENJAMIN, Walter. Obras escolhidas. Vol. 1. Magia e técnica, arte e política. Ensaios sobre literatura e história da cultura. São Paulo: Brasiliense, 1987, p. 222-232. Capturado em 05 de dez. 2011. Online. Disponível em: <http://rae.com.pt/wb2.pdf> .

. A tarefa do tradutor. In: GAGNEBIN, Jeanne-Marie (org.). Escritos sobre Mito e Linguagem. São Paulo: Editora 34, 2011.

BLOOM, Harold. A angústia da influência: uma teoria da poesia. Trad. Artur Nestrovski. Rio de Janeiro: Imago, 1991.

versity, 2011.

E-book. The Anatomy of Influence: Literature as a way of life. Ed. Yale Uni- 
BOURRIAUD, Nicolas. Post produccion. Buenos Aires: Adriana Hidalgo, 2004.

CAMERON, Dan; Herkenhoff, Paulo. Cildo Meireles. São Paulo: Cosac \& Naify, 2000..

CAMPOS, Haroldo. A operação do Texto. São Paulo: Perspectiva, 1976.

GAGNEBIN, Jeanne Marie. História e narração em W. Benjamin. São Paulo: Perspectiva, 2009.

HELDER, Herberto. Onolof: Poemas mudados para o português. Lisboa: Assírio \& Alvim, 1997.

As Magias: poemas mudados para o português. Lisboa: Assírio \& Alvim, 2010.

HERKENHOFF, Paulo. Por que Cildo? - Duchamp e Cildo e Duchamp. Catálogo da Exposição Por que Duchamp? Paço das Artes, São Paulo, 1999.

HUNT, John Dixon. Nature over again: The garden of Ian Hamilton Finlay. Londres: Reaktion Books, 2008.

KWON, Miwon. One place after another. Cambridge: MIT Press, 2002.

LAGES, Susana. Walter Benjamin: tradução e melancolia. São Paulo: Edusp, 2002.

LAGNADO, Lisette. Leonilson: são tantas as verdades. São Paulo: DBA Artes Gráficas Companhia Melhoramentos de São Paulo, 1998.

MAN, Paul de. Alegorias da Leitura. Rio de Janeiro: Imago, 1996.

MEIRELES, Cildo. Cildo Meireles. São Paulo: Cosac \& Naify, 1999. 
MELO NETO, João Cabral de. Duas Águas: Poemas Reunidos. Rio de Janeiro: José Olympio, 1956.

. Poesia Crítica: Antologia. Rio de Janeiro: José Olympio, 1982.

MESQUITA, Ivo. Leonilson: use, é lindo, eu garanto. São Paulo: Cosac \& Naify, 1997.

OBRIST, Hans Ulrich. Arte Agora: 5 entrevistas. São Paulo: Alameda, 2006.

OITICICA, Helio. Aspiro ao Grande Labirinto. Rio de Janeiro: Ed. Rocco,1986.

ROSENTHAL, Evelyn; PINO, María Esther. Jac Leirner in conversation with Adele NelsonI. Seattle: Marquand Books, 2011.

SAPPINGTON, Rodney (ed.). Between Artists. Nova Iorque: Art Publishers, 1996.

SECCHIN, Antonio Carlos. João Cabral: a poesia do menos. São Paulo: Duas Cidades, 1985.

SHEELER, Jessie. Little Sparta: the garden of Ian Hamilton Finlay. Londres: Frances Lincoln, 2003.

SHÜLER, Donaldo. Heráclito e seu (dis)curso. Porto Alegre: L\&PM, 2000.

WESSELING, Janneke (ed.). See it again, say it again: the artist as researcher. Amsterdam: Antennae, 2011.

ZAMBONI, Silvio. Pesquisa e Arte: Um paralelo entre arte e ciência. Ed. Autores Associados, Campinas, SP, 2006. 


\section{Teses e dissertações}

CESAR, Vitor. O artista é público. 2009. Dissertação em Artes Plásticas/Poéticas Visuais. ECA-USP, São Paulo, 2009.

HONORATO, Cayo. A formação do artista. 2011. Tese de Doutorado em Educação, FE-USP, São Paulo, 2011.

LUCAS, Renata. Visto de dentro, visto de fora. 2008. Tese de Doutorado em Artes Plásticas/Poéticas Visuais. ECA-USP, São Paulo, 2008.

MENNA BARRETO, Jorge. Lugares Moles. 2007. Dissertação em Artes Plásticas/Poéticas Visuais. ECA-USP, São Paulo, 2007.

PLAZA, Julio. Sobre Tradução Intersemiótica. 1984. Tese de Doutorado em Comunicação e Semiótica. PUCSP, São Paulo, 1984.

TAVARES, Ana Maria. Armadilhas para os Sentidos: uma experiência no espaço-tempo da arte. 2000. Tese de Doutorado em Artes Plásticas/Poéticas Visuais. ECA-USP, São Paulo, 2000.

\section{Catálogos de Exposições}

ALZUGARAY, Paula (org.). Vizinhos. Catálogo da exposição. Galeria Vermelho. São Paulo: Akrobatika, 2003.

CRUZ, Amanda Felix Gonzales-Torres. Catálogo da exposição. Museu de Arte Contem- 
porânea de Los Angeles. Los Angeles: Russel Ferguson (ed.), 1994, p.16.

BASBAUM, Ricardo. O artista como curador. Panorama. Catálogo da Exposição. Museu de Arte Moderna. São Paulo, 2001. p. 35.

GUERRERO, Inti.A Cidade do Homem Nu. Catálogo da Exposição. Museu de Arte Moderna. São Paulo, 2010.

\section{Revistas}

Art and Research. Online. Disponível em: <http://www.artandresearch.org.uk/>

Mabkuzine 8. Inverno 2010. Online. Disponível em: <[www.mahku.nl/download/ maHKUzine08_web.pdf]

Revista Número (2 e 3). Centro Maria Antonia/USP, São Paulo, 2003.

Revista Trópico. Online. Disponível em: http://p.php.uol.com.br/tropico/html/index.shl

Revista Marcelina: Artista-Arquiteta, n.6.Faculdade Santa Marcelina, São Paulo, 2011. Online. Disponível em: <http://www.fasm.edu.br/Site-Perdizes/revista-marcelina-6.pdf>.

Revista Urbania 3, Editora Pressa, São Paulo, 2008.

Text zur Kunst. Verlag. Berlim, junho, 2011. 


\section{Artigos}

ALVES, Cauê. Helio Oiticica: Cinema e Filosofia. Revista FACOM, n.21, São Paulo, 2009. Online. Disponível em: <http://www.faap.br/revista_faap/revista_facom/facom_21/caue.pdf>.

BARTHES, Roland. A morte do autor. In: BARTHES, Roland. O Rumor da Lingua. Editora Brasiliense, 1988. Capturada em 05 jan. 2012. Online. Disponível em: <http:// www.eca.usp.br/ciencias.linguagem/L3BarthesAutor.pdf>.

BASBAUM, Ricardo. Amo os artistas-etc. In: Politicas Institucionais, Práticas Curatoriais. MOURA, Rodrigo (Org.), Belo Horizonte, Museu de Arte da Pampulha, 2005. Capturado em 05 dez. 2011. Online. Disponível em: <http://rbtxt.wordpress.com/>

BENJAMIN, Walter. A tarefa do tradutor. In: GAGNEBIN, Jeanne-Marie (org.). Escritos sobre Mito e Linguagem. São Paulo: Editora 34, 2011.

DEUTSCHE, Rosalyn. A arte de ser testemunha na esfera pública dos tempos de guerra. Revista Concinnitas, n. 15. Pós-Graduação UERJ. Rio de Janeiro, 2009, p. 174-183 (trad. Jorge Menna Barreto).

FOUCAULT, Michel. O que é um autor? In: FOUCAULT, Michel. Ditos e Escritos: Estética - literatura e pintura, música e cinema (vol. III). Rio de Janeiro: Forense Universitária, 2001. p. 264-298. Capturado em 24 out. 2011. Online. Disponível em: <http:// fido.rockymedia.net/anthro/foucault_autor.pdf>

GALVÃO, Edilamar. O estranhamento da tradução na criação. In: NUNES, Sandra Regina Chaves (org.). Estranhas Travessias. Osasco: EDIFIEO, 2004, p. 59. 
KWON, Miwon. Um lugar após o outro: anotações sobre o site-specificity. Arte E Ensaios 17. Programa de Pós-Graduação em Artes Visuais, EBA, UFRJ, Rio de Janeiro, 2008 (trad. Jorge Menna Barreto).

. O lugar errado. Revista Urbania 3, Editora Pressa, São Paulo, 2008, p. 98 (trad. Jorge Menna Barreto).

MAGALHÃES, Celia. Tradução e Transculturação: a teoria monstruosa de Haroldo de Campos. Capturado em 05 dez. 2011. Online. Disponível em: <http://www.journal.ufsc. br/index.php/traducao/article/download/5384/4927>.

MAHARAJ, Sarat. Perfidious Fidelity: the untranslatability of the other. In: CAMPBELL, Sarah; TAWADROS, Gilane (ed.). Annotations 6. Londres: Iniva, 2001, p26.

MAZZUCCHELLI, Kiki. Arquitetura pobre: Lina Bo Bardi e o vernacular brasileiro. Revista Marcelina: Artista-Arquiteta. n.6, Ed. Faculdade Santa Marcelina, São Paulo, 2011, p. 35. Capturado em 10 jan. 2012. Online. Disponível em: <http://www.fasm.edu. $\mathrm{br} /$ Site-Perdizes/revista-marcelina-6.pdf $>$.

PEDROSA, Mário. Por dentro e por fora das Bienais. In: AMARAL, Aracy (org.). Mário Pedrosa - mundo, homem, arte em crise. Coleção Debates. São Paulo: Perspectiva, 1975.

Perfis E Entrevistas - Escritores, artistas e cientistas. Entrevista João Cabral de Melo Neto. Capturado em 15 ago. 2011. Online. Disponível em <http://www.livrariacultura. com.br/imagem/capitulo/3159329.pdf>.

ROELSTRATE, Dieter. The Way of the Shovel. E-flux. Capturado em: 08 jan. 2012. Online. Disponível em: <http://www.e-flux.com/journal/the-way-of-the-shovel-on-the-archeological-imaginary-in-art/>. 
SANTOS, Maria Ivone. Situações de Leitura na Arte Contemporânea. Revista Palíndromo 2, CEART/UDESC. Capturado em $1^{\circ}$ dez. 2011. Online. Disponível em: <http:// ppgav.ceart.udesc.br/revista/edicoes/2processos_artisticos/2_palindromo_santos.pdf>

SELIGMAN-SILVA, Marcio. De Flusser a Benjamin - do pós-aurático às imagens técnicas (2007). Capturado em 12 dez. 2011. Online. Disponível em <http://www.flusserstudies.net/pag/08/seligmann-flusser-benjamin.pdf $>$ (p.5).

\title{
Sites
}

\author{
http://en.wikipedia.org \\ www.e-flux.com \\ www.youtube.com \\ http://www.archello.com \\ http://jorgemennabarreto.blogspot.com \\ http://rbtxt.wordpress.com/
}




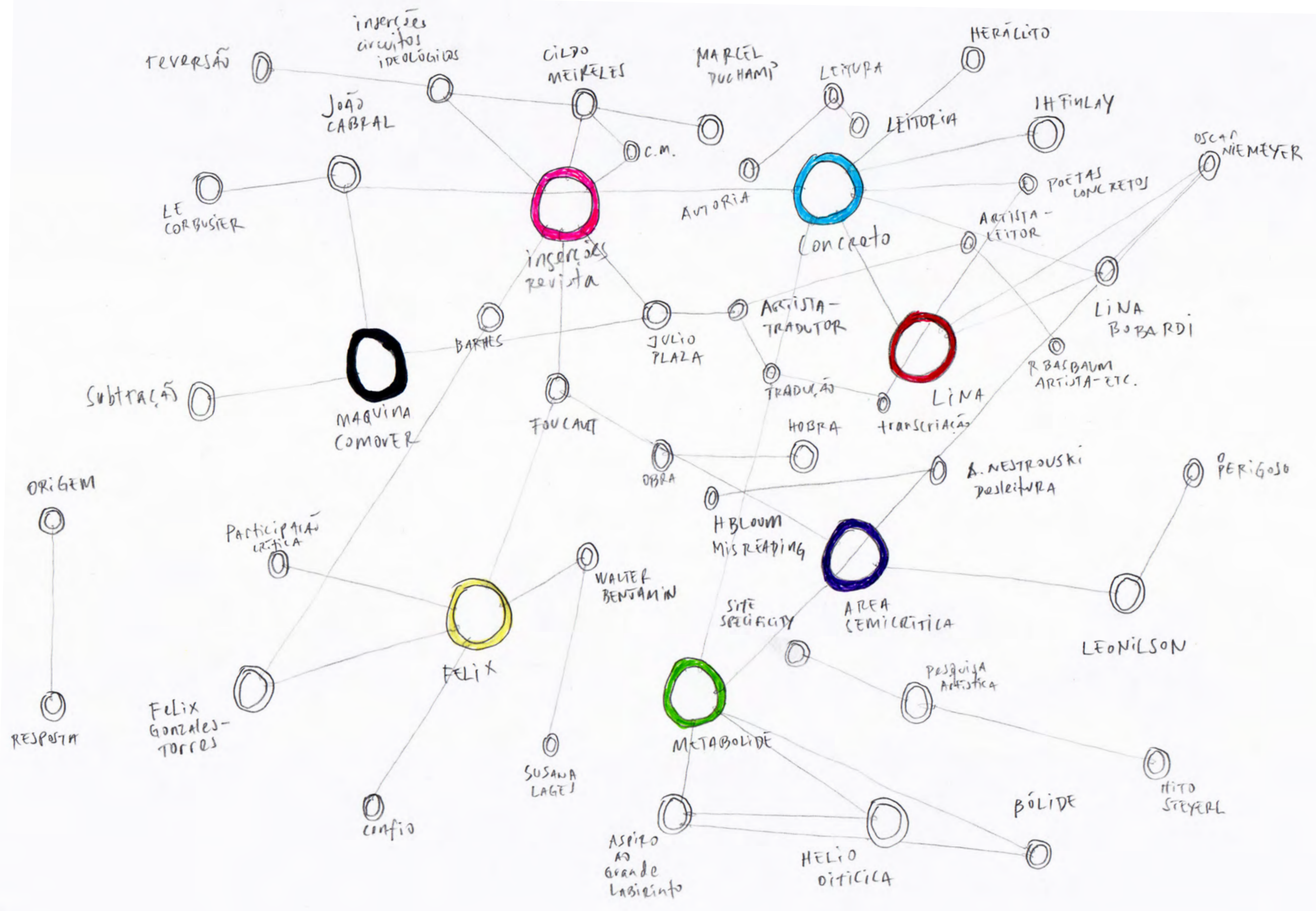


ANEXO 


\section{Estética da Resistência? \\ Pesquisa artística como Disciplina e Conflito ${ }^{1}$}

Hito Steyerl

Tradução: Jorge Menna Barreto

Revisão: Gavin Adams

O que é pesquisa artística hoje? No presente, ninguém parece saber a resposta para esta pergunta. A pesquisa artística é tratada como uma das múltiplas práticas que são definidas pelas indefinição, constantemente em fluxo, sem coerência e identidade. Mas e se essa visão estivesse equivocada? E se soubéssemos mais do que imaginamos sobre o assunto? Para discutir esta proposição, vamos primeiro olhar para os debates atuais em torno da ideia de pesquisa artística. Parece que uma das preocupações mais importantes é a transformação da pesquisa artística em uma disciplina acadêmica. Há discussões sobre currículo, graus, método, aplicação prática e pedagogia. Por outro lado, há também uma crítica substancial a esta abordagem. Endereça-se à institucionalização da pesquisa artística como sendo cúmplice dos novos modos de produção dentro do capitalismo cognitivo: educação como mercadoria, indústrias criativas e afetivas, estética administrativa, entre outros. Ambas perspectivas concordam em um ponto: a pesquisa artística no presente tem sido constituída como uma disciplina acadêmica mais ou menos normativa.

Uma disciplina é obviamente disciplinarizante; ela normaliza, generaliza e regula; ela ensaia um grupo de respostas, e neste caso, treina pessoas a funcionarem em um ambiente de trabalho simbólico, design permanente e criatividade canalizada. Mas de novo, o que é uma disciplina além disso tudo? Uma disciplina pode ser opressiva, mas é também precisamente por isso que ela aponta para o assunto que ela tenta controlar. Ela é índice de um conflito em potencial, suprimido ou evitado. Uma disciplina sugere um conflito imobilizado. É uma prática para canalizar e explorar suas energias e incorporá-las aos poderes vigentes. Por que alguém precisaria de uma disciplina se não fosse para disciplinar alguém ou algo? Qualquer disciplina pode ser vista portanto do ponto de vista do conflito.

Deixe-me dar um exemplo: um projeto que realizei recentemente, chamado The Building. Ele lida com a história da construção de um prédio nazista na praça principal de Linz, Austria; investiga seu passado, a história das pessoas que o construíram, e também analisa os materiais usados na construção. A construção foi realizada parcialmente por mão-de-obra forçada e alguns dos ex-habitantes do local foram perseguidos, desapoderados e assassinados. Durante a pesquisa, também descobriu-se que algumas das pedras da construção foram produzidas na notória pedreira do campo de concentração Mauthausen, onde milhares de pessoas foram mortas.

1 O texto em inglês foi originalmente publicado na Mahkuzine 8, inverno 2010. Online. Disponível em: $<$ www.mahku.nl/download/maHKUzine08_web.pdf >. Hito Steyerl é artista e professora na Universidade de Arte de Berlim. 
Há pelo menos duas maneiras diferentes de descrever este prédio. Pode ser dito que as mesmas pedras usadas na construção ganharam a sua forma de acordo com o paradigma da arquitetura neoclássica, que seria a descrição oficial dada sobre o edifício em si. Ou elas podem ser descritas como tendo sido, provavelmente, trabalhadas por um pedreiro no campo de concentração Mauthasen, e que era talvez um ex-lutador da Espanha Republicana. A conclusão é óbvia: a mesma pedra pode ser descrita pelo ponto de vista da disciplina, que classifica e nomeia. Mas também pode ser lida como um rastro de um conflito suprimido.

Mas por que este projeto tão específico seria relevante para uma reflexão sobre pesquisa artística enquanto tal? Porque partes deste edifício também abrigam coincidentemente a Academia de Arte de Linz. Este prédio é uma lugar onde a pesquisa artística tem sido integrada às estruturas acadêmicas: há um departamento para pesquisa artística dentro deste prédio. Portanto, qualquer investigação do prédio pode tornar-se uma espécie de metareflexão institucional sobre as condições contemporâneas da pesquisa artística enquanto tal.

Neste sentido: onde está o conflito, ou melhor, quais são os extensos conjuntos de conflitos subjancentes a essa nova disciplina acadêmica? Quem tem construído suas paredes, usando quais materiais, produzidos por quem? Quem são os construtores da disciplina e onde estão seus rastros?

\section{Disciplina e conflito}

Então, quais são os conflitos, e onde estão os limites portanto? Observado a partir do ponto de vista de muitas contribuições atuais, a pesquisa artística parece mais ou menos confinada à academia de arte contemporânea e metropolitana. A pesquisa artística atual parece ser um conjunto de praticas artísticas realizadas por artistas predominantemente metropolitanos que atuam como etnógrafos, sociólogos e designers sociais e de produto. Dá a impressão de ser uma propriedade valiosa do tecnologica e conceitualmente avançado capitalismo do Primeiro Mundo, tentando atualizar [as habilidades] de sua população para funcionar de maneira eficiente numa economia do conhecimento, e, como subproduto, casualmente investigando o resto do mundo também. Mas se olharmos para a pesquisa artística a partir da perspectiva do conflito, ou, mais precisamente, das lutas sociais, um mapa de práticas emerge ao longo do século XX, e numa grande parte do mundo. Torna-se óbvio que os atuais debates não reconhecem integralmente o legado da longa, variada e realmente internacional história da pesquisa artística, que já foi entendida em termos de uma estética da resistência.

Estética da Resistência é o título do romance seminal de Peter Weiss, lançado no início da década de 1980, que apresenta uma leitura alternativa da história da arte, assim como um relato da história da resistência anti-fascista de 1933 a 1945. Ao longo do romance, Weiss usa explicitamente o termo "pesquisa artística (künstlerische Forschung)" para referir-se a práticas como a de Brecht escrevendo em exílio. Ele também aponta para as práticas factográficas e parcialmente também produtivistas da União Soviética pós-revolucionária, mencionando o trabalho documentário de Sergei Tretjakov, entre outros. Assim, estabelece uma genealogia da pesquisa artística, que está relacionada à história das lutas por emancipação ao longo do século XX.

Desde a década de 1920, debates extremamente sofisticados sobre epistemologias artísticas foram travados 
sobre termos como fato, realidade, objetividade e investigação nos círculos dos factógrafos, cinematógrafos e artistas soviéticos. Para um factógrafo, um fato é um resultado de um processo de produção. "Fato" vem de facere, fazer. Então neste sentido, o fato é produzido, ou até mesmo inventado. Isto não é surpreendente para nós numa época de cetisismo pós-estruturalista e metafísico. Mas a amplitude de abordagens estéticas que foram desenvolvidas como ferramentas de pesquisa há quase 100 anos é espantosa.

Autores como Vertov, Stepanova, Tretjakov, Popova e Rodchenko inventaram procedimentos complexos de investigação, tal como o cine-olho, o cine-verdade, a biografia do objeto ou fotomontagem. Eles trabalharam sobre a percepção e prática humanas e ativamente tentaram integrar atitudes científicas ao seu trabalho. E a criação científica tem fluído como um resultado de muitos desses desenvolvimentos. Em sua autobiografia, Roman Jakobson descreve em detalhe como a práticas artísticas de vanguarda o inspiraram a desenvolver suas ideias específicas sobre linguística.

É claro que ao longo da história houveram muitas abordagens diferentes deste tipo de pesquisa. Poderíamos mencionar também o empenho dos artistas contratados pela FSA (Farm Security Administration) em criar uma investigação fotojornal- ensaística durante a Grande Depressão nos EUA. Em todos esses casos, a pesquisa artística é co-optada pelas políticas de Estado - embora em uma extensão distinta e com consequências completamente diferentes. Por volta da mesma época em que Tretyakov foi executado durante o terror stalinista, Walter Evans fez uma exposição individual no MoMa.

Outro método de investigação artística, que é baseado em vários conjuntos de conflitos e crises relacionados é a abordagem ensaística. Em 1940, Hans Richter cunha o termo filme-ensaio ou ensaio-filme como sendo capaz de dar visualidade a ideias teóricas. Ele se refere a um trabalho de sua autoria feito em 1927, chamado Inflation, um filme experimental extremamente interessante sobre o descontrole do capitalismo. Richter defende que uma nova linguagem fílmica tem que ser desenvolvida para lidar com processos abstratos tal como a economia capitalista. Como alguém pode mostrar essas abstrações, como alguém visualiza o imaterial? Estas questões são reatulizadas em práticas artísticas contemporâneas, mas têm uma longa história.

O ensaio como abordagem fílmica também abraça a perspectiva da resistência anticolonial. Um dos primeiros filmes chamado de filme-ensaio é o anticolonial Les statues meurent aussi, de Chris Marker e Alain Resnais, sobre o racismo ao lidar com a arte africana. O filme foi comissionado pela revista chamada Presence africaine, que conta com editores como Aimé Césaire ou Leopold Senghor, teóricos centrais do então chamado Movimento Negritude de 1930. Apenas alguns anos mais tarde, aparece o texto de Theodor Adorno, The Essay as Form, no qual ele pondera sobre as características de resistência do ensaio como método subversivo de pensamento. Para Adorno, o ensaio significa a reorganização dos campos do estético e epistemológico, que mina a divisão dominante do trabalho.

E então entramos no período da década de 1960 com suas lutas internacionais, tricontinentalismo e assim por diante. O slogan de Frantz Fanon: "[...] nós devemos discutir, nós devemos inventar..." é o lema do manifesto Towards a Third Cinema, escrito por Fernando Solanas e Octavio Getino em 1969, num contexto de ditadura 
na Argentina. A relação entre arte e ciência é de novo explicitamente mencionada no manifesto de Julio Garcia Espinosa, For an Imperfect Cinema (1969). Outros métodos de pesquisa artística incluem a deriva situacionista e a investigação de trabalhadores, montagens construtivistas, cut ups, biomecânica, história oral, antropologia desconstrutiva e surrealista, a difusão da contrainformação, além do jornalismo estético. Alguns desses métodos são mais facilmente absorvidos pelo mainstream da arte do que outros. Especialmente práticas fortemente desmaterializadas com características modernistas pronunciadas são rapidamente absorvidas pelo capitalismo informacional, porque são compactas, rápidas de absorver e facilmente transmitidas.

Não é uma coincidência que muitas das práticas mencionadas aqui têm lidado com problemas clássicos da representação documental a partir de perspectivas muito diferentes: sua função como poder/conhecimento, seus problemas epistemológicos, sua relação com a realidade e o desafio de criar uma nova. Estilos e formas de documentário têm há muito se fixado na mistura assimétrica entre racionalidade e criatividade, entre subjetividade e objetividade, entre poder de criação e poder de conservação.

Também não é uma coincidência que muitos dos métodos históricos de pesquisa artística estejam atrelados a movimentos sociais ou revolucionários, ou a momentos de crise e reforma. Nesta perspectiva, o esboço de uma rede global de lutas é revelado, que se estende por quase todo século XX, e que é transversal, relacional, e (em muitos, embora longe de todos os casos) emancipatório.

É uma coincidência, no entanto, que $A$ Estética da Resistência de Peter Weiss também mencione a praça central de Linz: o local de The Building. Ele descreve uma cena na qual membros da Brigada Internacional na Espanha escutam uma transmissão na recepção fervorosa feita para Hitler e as tropas alemãs na praça central de Linz em março de 1938. Mas o protagonista de Weiss nota um pequeníssimo (e completamente hipotético) momento de resistência apontado pelo jornalista do rádio: algumas das janelas na praça permanecem sem luz, e o jornalista é rápido ao apontar que é onde estão os apartamentos dos judeus. Em realidade, durante a pesquisa descobriu-se que uma das famílias judias que morava lá tinha dispersado para três continentes diferentes e dois membros da família tinham sido assassinados. Um deles era uma pessoa chamada Ernst Samuely, supostamente comunista. Depois de muitas provações, ele se juntou a um grupo judeu partidário na fronteira polonesa antes de desaparecer. Então, se olharmos para o prédio de Linz a partir deste ponto de vista, veremos que se dissolve em uma rede internacional de rotas e relações, relacionadas tanto à opressão como à resistência: relaciona-se com o que Walter Benjamin uma vez chamou de "a tradição do oprimido".

\section{A perspectiva do conflito}

Se continuarmos aplicando a perspectiva global e transversal ao debate sobre pesquisa artística, as limitações temporais e espaciais dos debates contemporâneos metropolitanos são revelados. Simplesmente não faz sentido algum continuar a discussão sem considerar que as práticas de pesquisa artística têm uma longa e extensa história, muito além das práticas artísticas conceituais - que é um dos pouquíssimos exemplos históricos mencionados, mesmo que raramente. Do ponto de vista das lutas sociais, a genealogia descontínua da pesquisa artística se torna quase global, com uma história longa e frequentemente interrompida. A distribuição geográfica 
das práticas de pesquisa artística também muda drasticamente a partir desta perspectiva. Desde que algumas localidades foram particularmente afetadas pela conjunção de poder e conhecimento, que emergiu com a formação do capitalismo e do colonialismo, estratégias de desobediência epistêmica tiveram que ser inventadas.

Poder/conhecimento/arte, que reduziu populações inteiras a objetos de conhecimento, dominação e representação, tiveram que ser contrariados não somente por lutas sociais e revolta, mas também por inovações estéticas e epistemológicas. Assim, revertendo a perspectiva e focando na disciplina como um índice de conflito, também reverte-se a direção na qual a história da arte tem sido escrita como uma estória de artistas periféricos que copiam e se atualizam em relação à história da arte ocidental. Nós poderíamos muito bem dizer que muitos artistas metropolitanos contemporâneos só agora estão se atualizando em relação à complexidade dos debates em torno da realidade e representação que factógrafos soviéticos já haviam desenvolvido na década de 1920

\section{Específico e singular}

Em todos esses métodos, dois elementos colidem: uma reinvindicação por especificidade se choca com uma reinvindicação por singularidade. O que isto significa? Um aspecto do trabalho reinvindica participar de um paradigma geral, dentro de um discurso que pode ser compartilhado e que é manufaturado de acordo com determinado critério. Muito frequentemente, procedimentos a serviço da verdade são subjacentes a este método de pesquisa. Estas metodologias são permeadas por relações de poder, como muitos teóricos já demonstraram.

Por outro lado, projetos de pesquisa artística em muitos casos também fazem uma reinvindicação pela singularidade. Eles criam uma certa situação artística, que reinvindica ser relativamente única e produz seu próprio campo de referência e lógica. Isso provê uma certa autonomia, e em alguns casos uma beirada de resistência contra modos dominantes de produção de conhecimento. Em outros casos, esta singularidade pretendida só excita uma pesquisa quantitativa, ou para usar uma expressão famosa de Benjamin Buchloh, cria uma estética da administração².

Enquanto métodos específicos geram um terreno compartilhado de conhecimento - que é consequentemente permeado por estruturas de poder - métodos singulares seguem sua própria lógica. Enquanto isto pode evitar a replicação de estruturas existentes de poder/conhecimento, também cria o problema da proliferação de universos paralelos, onde cada um fala a sua própria e intraduzível língua. Práticas de pesquisa artística costumam participar destes dois registros, tanto do singular quanto do específico; falam muitas línguas ao mesmo tempo.

Assim, pode-se imaginar uma praça semiótica*, que grosseiramente mapearia as tensões que se tornam aparentes durante a transformação da pesquisa artística em uma disciplina acadêmica e/ou econômica. É claro que este esquema é enganador, já que teria-se que desenhar um novo para cada ponto de vista singular que é investigado. Mas ele mostra as tensões que ao mesmo tempo enquadram e minam a institucionalização da pesquisa artística.

2 Benjamin H. D. Buchloh, "Conceptual Art 1962-1969: From the Aesthetic of Administration to the Critique of Institutions”, in: October, Vol. 55. (Winter, 1990), pp. 105-143. 


\section{Pesquisa artística enquanto tradução}

O multilingualismo da pesquisa artística implica que a pesquisa artística seja um ato de tradução. Ela se dá em pelo menos duas línguas e pode, em alguns casos, criar uma outra. Ela fala a língua da qualidade e também a da quantidade, a língua do singular e a língua do específico, valor de uso e valor de troca, ou valor do espetáculo, disciplina tal como conflito; e ela pratica a tradução entre todos esses. Isto não quer dizer que ela o faça corretamente - mas mesmo assim, traduz.

Neste ponto, deve-se enfatizar que este também é o caso com as assim-chamadas obras de arte autônomas, que não têm qualquer pretensão de participar em qualquer tipo de pesquisa. Isto não quer dizer que não podem ser quantificadas or tornar-se parte de práticas disciplinárias, porque elas são rotineiramente quantificadas no mercado de arte ao ganharem um preço e serem integradas à história da arte e outros sistemas de valor. Assim, a maior parte das práticas artísticas existe em um ou outro tipo de tradução, mas este tipo de tradução não põe em perigo a divisão de trabalho estabelecida por historiadores de arte e galeristas, entre artistas e pesquisadores, entre mente e sentidos. De fato, muito da animosidade conservadora em relação à pesquisa artística surge a partir de um sentimento de ameaça, por causa da dissolução dessas fronteiras, e é por isso que a pesquisa artística é frequentemente destratada na prática cotidiana como não sendo arte nem pesquisa.

Mas os processos de quantificação envolvidos na avaliação e valorização da pesquisa artística são levemente diferentes daqueles procedimentos tradicionais de quantificação. Pesquisa artística como disciplina não somente cria e reforça certos padrões, mas também apresenta uma tentativa de extrair ou produzir um tipo diferente de valor em arte. À parte do mercado de arte, um mercado secundário paralelo se desenvolve para aquelas práticas às quais falta do valor de fetiche. Este valor secundário é estabelecido pela quantificação e integração aos (crescentes) sistemas de educação mercantilizados. Além disso, há um tipo de ganho social embutido em um entendimento pedagógico da arte que entra em jogo. Os dois combinados criam um empuxo na direção da produção do par conhecimento/arte aplicado ou aplicável, que pode ser usado para inovação empresarial, coesão social, marketing municipal, e milhares de outros aspectos do capitalismo cultural. A partir desta perspectiva, a pesquisa artística de fato se parece como uma nova versão das artes aplicadas, um ofício novo e largamente imaterial, que tem sido instituído como disciplina em muitos e distintos lugares.

\section{Radiadores}

Finalmente, deixe-me retornar ao começo: nós sabemos mais sobre pesquisa artística do que pensamos. $\mathrm{E}$ isso diz respeito aos achados mais inquietantes em torno do projeto The Building em Linz. É mais do que provável que depois da guerra os radiadores tenham sido levados do hoje abandonado campo de concentração Mauthausen e reinstalados no prédio. Se este plano documentado nos arquivos históricos foi levado a cabo, então os radiadores ainda estão lá e têm aquecido o prédio silenciosamente desde então. Uma visita com um especialista confirmou que os radiadores nunca foram trocados na parte leste do prédio e que, além disso, alguns radiadores já tinham sido usados quando foram instalados em 1948. A fabricação destes radiadores corresponde aos poucos radiadores vistos em fotos do campo de concentração Mauthasen. Agora, é claro, radiadores não eram usa- 
dos nas barracas dos prisioneiros. Eles eram usados em alguns locais de trabalho, como a lavanderia. Eles eram usados no escritório e no bordel, onde prisoneiras de um outro campo de concentração tinham que trabalhar.

Mas o que fazer com o fato de que o Departamento de Pesquisa Artística (seu escritório de coordenação está localizado no prédio, de acordo com o website) poderia em breve ser aquecido pelos mesmos radiadores, que foram testemunhas mudas do apuro das prisioneiras no bordel do campo de concentração? Para citar o website da academia de arte de Linz, "pesquisa artística-científica pertence às atividades nucleares na Universidade de Arte de Linz, e prática artística e pesquisa científica estão combinadas sob um mesmo teto. A confrontação e/ ou combinação de ciência e arte requer uma pesquisa intensa e desenvolvimento artístico sob uma perspectiva metodológica, nas áreas de transferência de conhecimento e questões de mediação. Estudos culturais, história da arte, teoria de mídia, diversas estratégias de mediação, assim como Estudos de Gênero no contexto da produção concreta de arte são elementos essenciais do perfil da universidade". Quais são as condições dessa pesquisa? Qual a biografia da sua infraestrutura histórica e como que uma reflexão a respeito pode ajudar-nos a desconstruir o deslumbramento com a disciplina e a institucionalização e assim tornar mais preciso o foco histórico no pensamento sobre pesquisa artística? Obviamente, nem todo prédio irá revelar uma infraestrutura tão surpreendente. Mas a pergunta geral se mantem: o que fazemos com uma disciplina ambivalente, que é institucionalizada e disciplinada sob este tipo de condições? Como podemos enfatizar a dimensão histórica e global da pesquisa artística e sublinhar a perspectiva do conflito? E qual é o momento de apagar as luzes?

\section{CIÊNCIA/}

HISTÓRIA DA ARTE

DISCILINA

\section{DEBATE PÚBLICO/ CONTRAINFORMAÇAO}

\section{RESISTÊNCIA}

MERCADO DE ARTE/ INDÚSTRIA CRIATIVA

\section{AUTONOMIA ESTÉTICA}




\section{CRÉDITOS}

Revisão do texto: Patrícia Pitta

Design gráfico: Cynthia Vasconcellos

Revisão da tradução (anexo): Gavin Adams

Fotografias: Everton Ballardin, Cynthia Vasconcellos,

Raul Narevicius e Jorge Menna Barreto. 
